\title{
U. S. Geological Survey
}

Trace Elements and

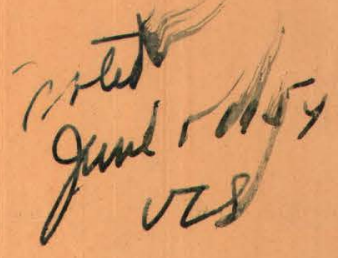

\section{Related Reports through 1953}

By Jane H. Wallace, Virginia K. Blatcher, and Harriet B. Smith

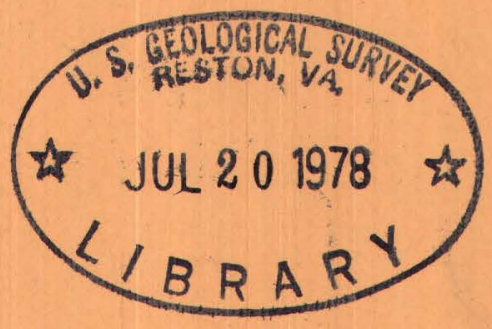

\section{Trace Elements Investigations Report 400}

UNITED STATES DEPARTMENT OF THE INTERIOR GEOLOGICAL SURVEY 


\author{
Geology and Mineralogy \\ Chemistry \\ Instrumentation \\ Physics \\ This document consists of 267 pages. \\ Series A
}

UNITED STATES DEPARTMENT OF THE INTERIOR

GEOLOGICAL SURVEY

U.S. GEOLOGICAL SURVEY TRACE ELEMENTS AND RELATED REPORTS

THROUGH 1953*

by

Jane $\mathrm{H}$. Wallace, Virginia K. Blatcher, and Harriet B. Smith

January 1954

Trace Elements Investigations Report 400

\begin{abstract}
This preliminary report is distributed without editorial and technical review for conformity with official standards and nomenclature. It is not for pubIic inspection or quotation.
\end{abstract}

*This report concerns work done on behalf of the Divisions of

Raw Materials and Research of the U。S.Atomic Energy Commission.

When separated from Parts I, III, and IV, handle Part II as UNCIASSIFIED. 


\author{
USGS - TEI-400 \\ GEOLOGY AND MINERALOGY \\ CHEMISTRY \\ INSTRUMENTATION \\ PHYSICS
}

Distribution (Series A)

No. of copies

American Cyanamid Company, Winchester ............... 1 Argonne National Laboratory ...................... 1 Atomic Energy Commission, Washington................. 1 Battelle Memorial Institute, Columbus . . . . . . ........ 1 Carbide and Carbon Chemicals Company, I-12 Area.......... 1

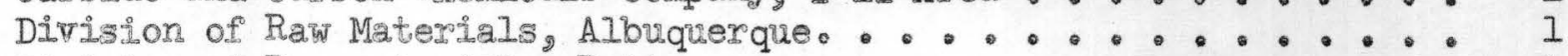
Division of Raw Materials, Butte................... 1 Division of Raw Materials, Denrer................... 1

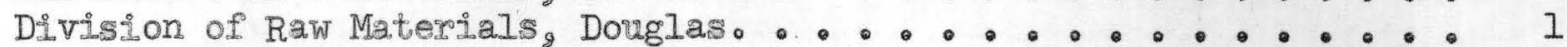
Divis:on of Raw Materials, Hot Springs. . . . . . . . . . . . 1 Division of Raw Materials, Ishpeming.................. 1 Division of Raw Materials, New York................ 12 Division of Raw Materials, Phoenix, .................. I

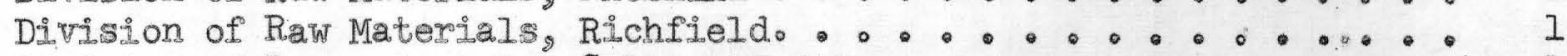
Division of Raw Materials, Salt Iake City . . . . . . . . . . 1

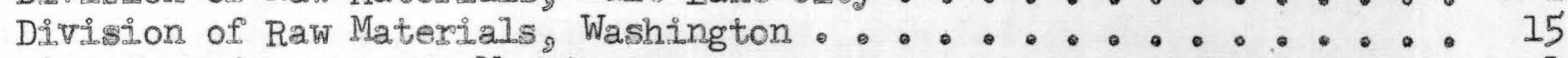

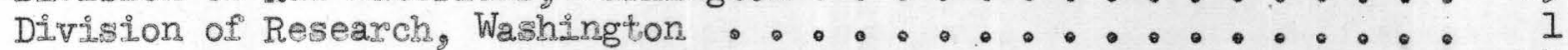
Dow Chemical Company, Pittsburg ................... . 1 Exploration Division, Grand Junction Operations Office. . . . . . 6 Grand Junction Operations office.................... 2 Research Incoroorated, Dallas..................... I Technical Information Service, Oak Ridge............... 6 Tennessee Valley Authority, Wilson Dam .............. 1

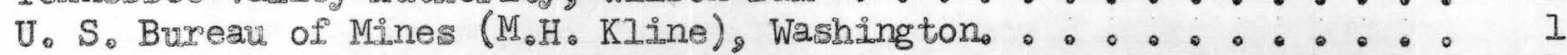

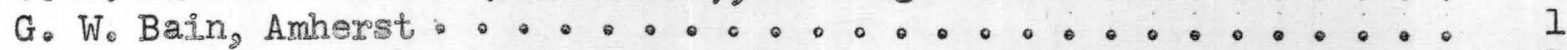

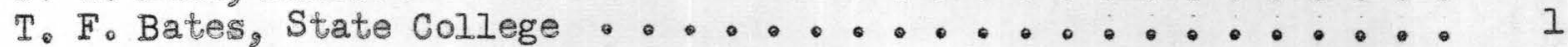

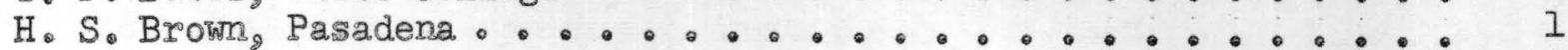
W. H. Bucher, New York . . . . . . . . . . . . 1

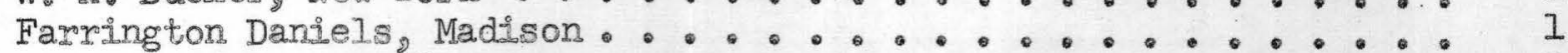
Clifford Frondel, Cambridge . . . . . . . : . : . : 1

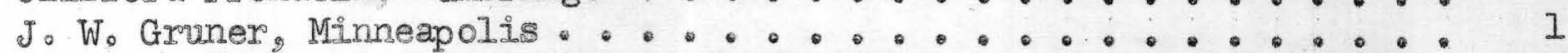

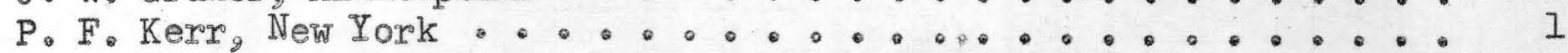

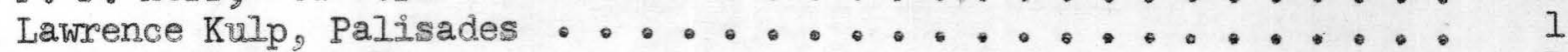

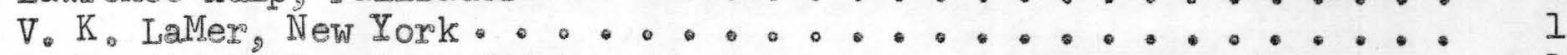

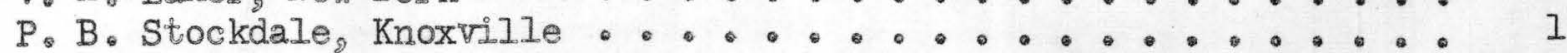

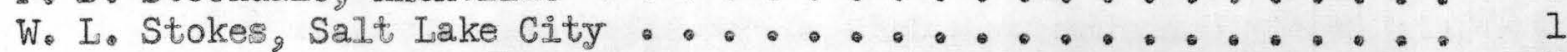
H. D. Wright, State College...................... 1

U. S. Geological Survey:

Mineral Deposits Branch, Washington................ 20

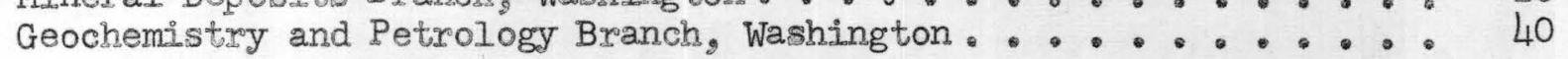


U. S. Geologiocal Surovey (continued):

Geophysics Branch, Washington .......... ........ 5 Alaskan Geology Branch, Washington, ............. 10 Fuels Branch, Washington ..................... 8 Forelgn Geology Branch, Washington Military Geology Branch, Washington ................ I Conservation DIvision, Washington,.............. I Water Resources Division ( $V$ o T. Stringfield), Washington。 ...... I Paul Applin, Jackson (Miss,). .................. 1 E。 H。 Bailey, Menlo Park ................... 5 H. M. Bannerman, Washington ................... I

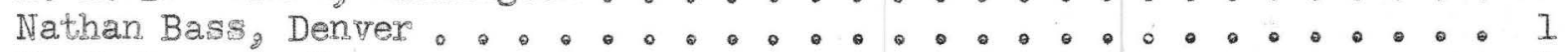
W. E. Benson, Denver ...................... I W. H. Bradley, Washington .................... I K. Is Buck, Denter ........................ 5 Ruth Butler, Washington ...................... 1 M. F。Byrd, Washington ....................... I

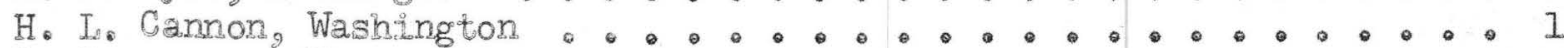

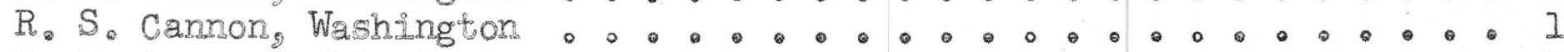
M. S. Carre Washington, ..................... . 1 I. C. Conanty University, Alabama ................. I

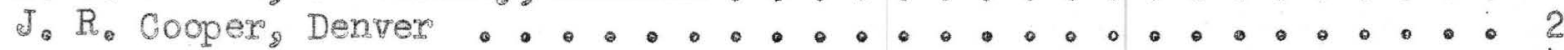

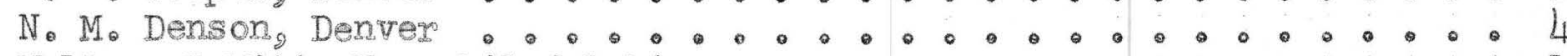
Wallace DeWitt, New Philadelphia. . . . . .......... I D. C. Duncan, Washington, ..................... I C. E. Dutitong Madison ...................... 2 D. H. Eargle, Austin . . . ................. 1 M. J. Ebner, Washington ...................... I E。 B. Eckel, Denver . . . . . . .............. I R. P. Fischers, Grand Junction............... . . 10 W. A, Fischer, Washington ................... . I I. S. Gardner, Albuquerque. ...................... I P. Guild, Washington, ...................... I F. No Houser, Tucson, ....................... . I J. Do Huddle, Lexington ..................... I A. R。 KInkel, Washington, .................. ... . 2

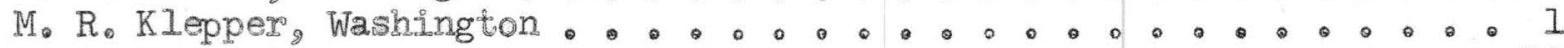

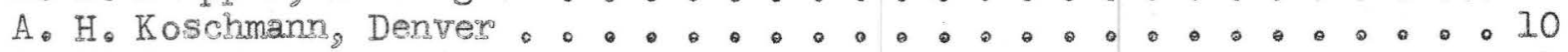
D. M。 Larrabee, Washington, . . ................. I R. A. Laurence, Knoxville ..................... I J. D. Love, Laramie ....................... . I T. S. Iovering, Denver. .................. . . . 1

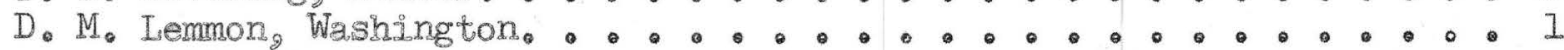
G.W. Iuttrell, WashIngton................... . I V. E. McKelvey, Menlo Park. ................. 5 F.A. McKeom, Beltsville .................... . I Kathleen McQqeen, Washington. ................... I Donald Myers, Austin. ...................... 1 T. B. Nolan, Washington .................... I W. C. Overstreet, Shelby. ................... I 
U. S. Geological Survey (continued):

I. R. Page, Denver ................... I Priscilla Patton, Denver .................. 2 J. Fo Pepper, New Philadelphia................. I R。 G. Petersen, Plant City .................. I J. C. Rabbitt, Washington ................. I Paul Richards, Billings. ..................... I J。 A。 Reinemund, Denver. .................... I R. J. Roberts, Salt Iake City................ 5 W. W. Rubey, Washington ................ I D. C, Schnabel, Denver ................. I J. M. Schopf, Columbus ................... I Q. D. Singewald, Beltsville................... . .

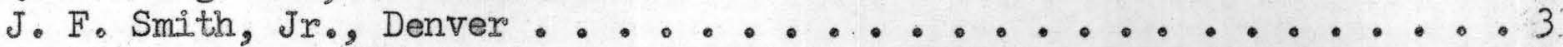
P. D. Snavely, Menlo Park. ................. I R. W. Swanson, Spokane .................. I R. E. Van Alstine, Washington.................. I Holly Wagner, Iawrence ................... I A. E. Weissenborn, Spokane ............... 5 M。 G。 White, Rio de Janerio.................. I G. H. Wood, Mt. Carmel ................... I A. O. Woodford, Claremont. .................. I

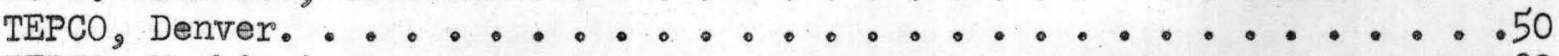

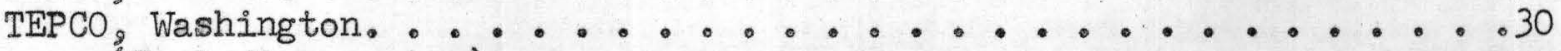
(Including master) 
CONTENTS

Page

Introduction . . . . . . . . . . . . . . . . 6

Part I. Numerical list of Trace Elements Reports. . . . . 8

1. Trace Elements Investigations Reports. . . . . 8

2. Trace Elements Memorandum Reports. . . . . . 41

Part II. Trace Elements and related reports available to the public . . . . . . . . . 95

1. Reports released in open file......... 95

a. Trace Elements Investigations Reports . . . 96

b. Trace Elements Memorandum Reports.... 100

c. Miscellaneous . . . . . . . 112

2. Trace Elements Reports issued by the U. S.

Atomic Energy Commission, Technical

Information Service, Oak Ridge, Tenn...... 114

a. Trace Elements Investigations Reports . . 116

b. Trace Elements Memorandum Reports ..... 122

3. Circulars.................. 125

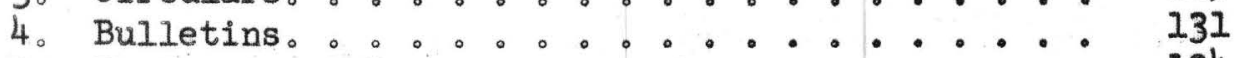

5. Professional Papers. . . . . . . . . 134

6. Geological Survey Oil and Gas maps and

Minerals Investigations Preliminary maps

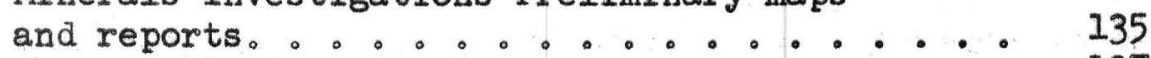

7. Geologic Quadrangle Map series........ 137

8. Publications in scientific journals. . . . 139

Part III。Finding list of states, areas, and subjects ..... 149

Part IV。 Finding list of authors . . . . . ...... 204 
U. S。 GEOLOGICAL SURVEY TRACE ELEMENTS AND RELATED REPORTS THROUGH 1953

By Jane H。Wallace, Virginia K. Blatcher, and Harriet B. Smith

\section{INTRODUCTION}

This report combines and brings up-to-date the information previously given in Trace Elements Investigations Report 325, "Numerical list of U. S. Geological Survey Trace Elements Reports to April 30, 1953," and Trace Elements Investigations Report 301, "Topical index and bibliography of U. $S$. Geological Survey Trace Elements and related reports."

Part I is a numerical list of U。S.Geological Survey Trace Elements Investigations and Memorandum reports. - It supersedes TEI-325. This part lists not only reports (followed by a date) that have been transmitted to the U. S. Atomic Energy Commission, but also reports in preparation (followed by an asterisk) for which tentative titles were available on December 31, 1953. Reports that have been published are indicated by the abbreviation of the medium of publication. (See also Part II.)

Part II is a reference guide to Trace Elements and related reports that are available to the public; this part supersedes Part 2 of TEI-30I (published as Geological Survey Circular 281). These reports are grouped according to the type of publication or release. Abstracts published in Nuclear Science Abstracts are not included in Part II, although certain TEI and TEM reports, the abstracts of which have been published in NSA, are so indicated in Part I. Publications in process on December 31, 1953, are designated by an asterisk.

\footnotetext{
Reports prepared by the Geologic Division of the Geological Survey on behalf of the Division of Raw Materials and the Division of Research of the U. S. Atomic Energy Commission.
} 
Part III is a finding list of states, areas, and subjects. It is based on information derived mostly from the titles of reports and, where titles are of a general nature, from a cursory review of the reports. This list is not a complete index of the information given in Trace Elements and related reports, but is designed to find subjects of major interest. Because of the numerous entries for Colorado and Utah, information has been listed by counties and, where possible, by subject under these states. Other states have county listings only if a county is included in the title of a report; otherwise, areas may be listed separately under the state. Major subjects are listed separately in the index and also, where appropriate, under states. Analytical methods and subjects related to analytical research are listed under Analytical Methods and Research, but not separately throughout the index. Most mineralogic studies are included under the heading Mineralogy, but are not necessarily listed according to location.

Part IV is a finding list of authors. The words "with" and "and" are used to indicate seniority of authorship. For example, a listing of Jones and Brown indicates that Jones is the senior author. A listing of Jones with Brown indicates that Brown is the senior author.

In both parts III and IV aII Trace Elements reports are listed, as well as other related reports that have not been issued as Trace Elements reports. The following standard abbreviations have been used: TEI, Trace Elements Investigations report; TEM, Trace Elements Memorandum report; P, Professional Paper; B, Bulletin; C, Circular; J, Journal; OF, open file; TIS, Technical Information Service release; NSA, Nuclear Science Abstracts; QM, Quadrangle Map Series; and OM, Oil and Gas map or Mineral Investigations map or report. 
U. S. GEOLOGICAL SURVEY TRACE EIEMENTS

AND RELATED REPORTS THROUGH 1953

by

Jane $H$. Wallace, Virginia $K$, Blatcher, and Harriet B. Smith

PART I. NUMERICAL LIST OF TRACE ELEMENTS REPORTS

(* Indicates report is in preparation. Title subject to change)

Abbreviations used: P, Professional Paper; B, Bulletin; C, Circular; J, Journal; OF, Open File; TIS, Technical Information Service; NSA, Nuclear Science Abstracts; QM, Quadrangle Map; OM, Oil and Gas Map.or Minerals Investigations Map or Report.

\section{TRACE ELEMENTS INVESTIGATIONS REPORTS}

1. Slaughter, A. I. and Clabaugh, S. E*, Eastern black shale reconnaissance, a preliminary report: (Confidential). August 1944.

2. Foster, M. D., Grimaldi, F. S., and Stevens, R。 E., Preliminary report on methods of analysis for very small percentages of uranium: (Unclassified). November 1944.

3. Slaughter, A。 I. and Clabaugh, S. E, Radioactivity of some North Carolina pegmatites, preliminary report: (Unclassified). August 1944.

4. Harder, J. O. and Wyant, $D_{0}, G_{0}$, Preliminary report on a trace elements reconnaissance in western states: (Official use only). October 1944.

5. Butler, A, $\mathrm{P}_{0}, \mathrm{Jr}$, and Chesterman, C. Wo, Investigation of trace elements in the Phosphoria formation in southwestern Montana, preliminary report: (Secret). January 1945. (Confidential, 3-4m54)

6. Harder, J. O and Reed, J. C., Preliminary report on radioactivity of some Alaskan placer samples: (Unclassified). February 1945.

7. Fleischer, Michael and Hardex, Jo O., The occurrence of germanium: (Unclassified). February 1945.

8. Brill, K. G., Jx., Nelson, J. Mo, and Prouty, C. E., Preliminary report, trace elements investigations, Hickman and adjacent Counties, Tennessee: (Secret). February 1945.

9. Slaughter, A。 L。 and Clabaugh, S, E。 , Preliminary report on trace elenents reconnaissance in central and southwestern states: (Official use only). March 1945. 
10. Fleischer, Michael and Harder, $J \circ O_{0}$, Trace elements investigations: The occurrence of indium: (Unclassified). April 1945.

11. Fleischer, Michael, The occurrence of xenon: (Secret), May 1945.

12. Butler, A, $\mathrm{P}_{0}, \mathrm{Jr}$ 。 and Chesterman, CoW, Trace elements reconnaissance in Alabama, Georgia, and North Carolina, preliminary report: (Secret). May 1945.

13. Stead, F.W., Preliminary report on field measurements of radioactivity: (Unclassified). May 1945.

14. Fleischer, Michael and Harder, J. Oo, Trace elements investigations: The occurrence of columbium and tantalum: (Unclassified). 1945.

15. Grimaldi, F, S. and Fairchild, J. G。, Preliminary report on methods of analysis for very small percentages of thorium: (Unclassified). 1945.

16. Fahey, Jo Jo and Foster, $M_{0} D_{0}$, Preliminary report on a method for the determinations of small quantities of thorium: (Unclassified). 1945.

17. Slaughter, A. I., Trace elements reconnaissance in Florida, preliminary report: (Confidential): September 1945.

18. Slaughter, A. I. Radioactivity of Pennsylvanian black shales and coals in Kansas and Oklahoma, preliminary report: (Official use only). September 1945 .

19. Brill, $K_{0} G_{0}, \mathrm{Jr}$. and Wolfe, J. R., Jr., Preliminary report, placer deposits of central Idaho: (Official use only). October 1945.

20. Slaughter, A. I. and Nelson, J. M., Trace elements reconnaissance in South Dakota and Wyoming, preliminary report: (Official use only). March 1946.

21. Harder, J. $D_{0}$ and Stead, $F$. W., Reconnaissance for radioactive ore deposits in the United States, summary of progress: (Secret). December 1945.

22. Nelson, J. $M_{3}$ and Brill, $K . G_{0}, J r \circ$, Radioactivity of the Chattanooga shale east of the Mississippi River and south of the Ohio River, an interim report: (Secret). August 1947.

23. Grimaldi, F. S., Elimination of interference by nickel in the deterninetion of uranium by means of zinc amalgam reductors: (Unclassified.). March 1946. (B-1006\% TIS).

24. Chesterman, C.W. and Main, F. H., Reconnaissance investigations for trace elements in Utah, Colorado, Nevada, California, and Oregon, prelimin= ary report: (Official use only). June 1947. 
25. Gault, H. R., Black, R. F., and Lyons, J. B., Preliminary report on trace elements investigations in the Sweepstakes Creek area, Koyuk district, Seward Peninsula, Alaska: (Unclassified). May 1946. $(\mathrm{C}-250)$.

26. Robinson, G. D., Wedow, Helmuth, Jr., and Lyons, J. B., Trace elements investigations in the Cache Creek-Upper Peters area, Yentna district, Alaska: (Unclassified). March 1946.

27. Killeen, P. L. and Ordway, R. J., Trace elements investigations at Ear Mountain, Seward Peninsula, Alaska: (Unclassified). May 1946.

28. Schlecht, W. G., Control chart method applied to errors in radioactive counting: (Unclassified). June 1946. (TIS).

29. Fleischer, Michael and Cameron, F. N., Geochemistry of beryllium: (Unclassified). June 1946. (TIS).

30. Chesterman, C. W. and Main, F. H., Reconna Issance in Jatan and Korea: (Secret). 1946. (Official use only, 3-4-54)

31. Foster, M. D., Stevens, R. E., Grimaldi, F. S., Schlecht, W. G., and Fleischer, Michael, Methods for the complete decomposition of rock and ore samples to be analyzed for very small amounts of uranium and thorium: (Confidential). 1946. (B-1006\% TIS).

31B. Foster, M. D. and Stevens, R. E., The determination of very small amounts of uranium in naturally occurring materials: (Confidential). 1946. (B-1006; TIS).

31C. Grimaldi, F. S., The determination of very small amounts of uranium in rocks and minerals: (Confidential). 1946. (B-1006*; TIS).

31D. Fahey, J. J. and Foster, M. D., The determination of small amounts of thorium in rocks and minerals: (Confidential). 1946. (B-1006; TIS).

3IE. Grimaldi, F. S. and Fairchild, J. G., The determination of very small amounts of thorium in naturally occurring materials: (Confidential). 1946. (B-1006; TIS).

3IF. Grimaldi, F. S., Elimination of interference by nickel in the determination of uranium by means of zinc amalgam reductor: (Unclassified). 1946.

3IG. Schlecht, W. G., Control chart method applied to radioactive counting: (Confidential). 1946.

31H. Fleischer, Michael and Harder, J. O., Geochemistry of indium: (Unclassified). 1946. (TIS).

31I. Fleischer, Michael and Harder, J. 0., Geochemistry of germanium: (Unclassified). 1946. (TIS). 
31J. Fleischer, Michael and Harder, J。O , Geochemistry of columbium and tantalum: (Unclassified). 1946. (TIS).

3IK. Fleischer, Michael and Cameron, $E, N_{0}$, Geochemistry of beryllium: (Unclassified)。1946。

32. Brill, $K_{0} G_{0}, J_{0}$ and Carroll, G。 Vo, Preliminary report, placer deposits of monazite in North Carolina: (Unclassified). September 1946.

33. Rove, O N $\mathbb{N}_{0}$ Trace elements reconnaissance: (Secret). December 1946.

34. Nelson, JoMo and Stratton, E。 Vo, Trace elements reconnaissance in Indiana, Illinois, Missouri, Arkansas, and Kentucky, preliminary report: (Unclassified). May 1949.

35. Butlex, $A_{0} P_{0}, J x_{0}, K_{i} l l e e n, P_{0} I_{0}$, Page, G。 Bo, and Rubey, W。 Wo, Prom posed program for and present status of the Geological Survey ${ }^{\gamma}$ in vestigation of domestic resources of radioactive raw materials: (Secret). January 1947 .

36. Butler, $A_{0} P_{0}, J x_{0}$ and Stead, $F_{0} W_{0}$, Present investigations of radioactive raw materials by the Geological Survey and a recommended prom gram for future work: (Secret)。 April 1947.

37. Fleischer, Michael and Rabbitt, J.C., The geochemistry of gallium: (Official use only). January 1947.

38. Wedow, Helmuth, Jro and Matzko, J. Jo, Trace elements reconnaissance along highways in the Tanana and Upper Copper River VaIleyi, Alaska: (Unclassified). March 1947.

39. Moxham, $R$ 。 $M_{0}$ and West, $W_{0} S$, , Trace Elements investigations in the SerpentinewKougarok area, Seward Peninsula, Alaska: (Unclassified). November 1949. (C=265)。

40. White, $M_{0} G_{0}$, Trace elements investigations in placer mining areas near Teller, Alaska: (Official use only). 1947. (C-244).

41. Gault, $H_{0} R_{0}$, Trace elements reconnaissance in the Candle Creek area, Fairhaven district, Seward Peninsula, Alaska: (Official use only). December 1949. (C-250)。

42. Killeen, $P$ 。 $L_{0}$ and White, $M_{0}, G_{0}$, Trace elements investigations in the Grant Creek area, Yukon region, Alaska: (Pt. 1, Unclassified). October 1949; Trace elements reconnaissance on the South Fork of Quartz Creek, northeastern Seward Peninsula, Alaska: (Pt, 2, Unclassified)。 May 1950。(C-250)。

43. Nelson, $J_{0} M_{0}$ and Brili, $K_{0} G_{0}, J r_{0}$, Preliminary report on radioactivity of asphaltites, coals, and shales, in Tennessee, Kentucky, West Virginia, and Pennsylvania: (Unclassified). October 1948. 
44. Grimaldi, F. S, and Marsh, C. A., The determination of thorium in highgrade and low-grade ores: (Unclassified). September 1947. $(\mathrm{B}-1006 *$; TIS).

45. White, M. G. and Killeen, P. I., Radioactivity and mineralogy of con(Part 1). centrates from the placers of Julian, Moore, and Candle Creeks, and the Cripple Creek Mountains, lower Yukon-Kuskokwim Highlands region, Alaska: (Pt. 1, Unclassified). February 1950. (C-255).

45. West, W. S, and Natzko, J.J., Radiometric and mineralogic studies of (Part 2). the granitic complex in the Cape Nome area, Seward Peninsula, Alaska: (Pt. 2, Unclassi-ied). May 1950. (C-244).

45C. Matzko, J。J., Radiometric examination of rock specimens from Mount McKinley, Alaska: (Unclassified). February 1951.

46. White, M. G. and Killeen, P. L。, Radioactivity investigations in the vicinity of Flat, Lower Yukon-Kuskokwim region, Alaska: (Unclassified). Apri1 1952. (C-255).

47. Grimaldi, F. S. and Levine, Harry, The rapid fluorimetric determination of uranium in low-grade ores, a preliminary report: (Unclassified). April 1948. (B-1006\%, OF; TIS).

48. Moxham, R. Mo, Trace elements reconnaissance of the southern highway belt, south-central Alaska: (Unclassified). May 1950. (C-184).

49. West, W. S. and Matzko, J. J., Reconnaissance for radioactive deposits in the Buckland-Kiwalik district, Candle quadrangle, Seward Penin= sula, Alaska: (Unclassified). March 1952. (C-250).

50. Wyant, D. G。, Staats fluorspar mine, Beaver County, Utah: (Unclassified). August 1948.

51. Wyant, D. G., Uranium-vanadium deposits at Shinarump Mesa and some ad=jacent areas, Temple Mountain district, Emery County, Utah: (Pt. I, Unclassified; Pt. 2, Official use only). January 1953.

52. Cott, G. B., Radioactivity of sediments in parts of Oklahoma and Kansas, preliminary report: (Unclassified). December 1948.

53. West, W. S., Reconnaissance for radioactive deposits in the Darby Nountains district, Seward. Peninsula, Alaska: (Unclassified). March 1953. (C-300; NSA).

54. Moxham, R. M., Reconnaissance for radioactive deposits in the Manley Hot Springs Rampart district, central Alaska: (Unclassified). May 1952. $(\mathrm{C}-317)^{*}$.

55. White, M. G., Reconnaissance for radioactive deposits along the upper Porcupine River, northeastern Alaska: (Unclassified). June 1951. $(\mathrm{C}-185)$. 
56. Wedow, HeImuth, Ir., Reconnaissance for radioactive deposits in the Eagle-Nation area, east central Alaska, 1948: (Unclassified). Argust 1953. (C-316; NSA).

57A. White, M。 Go Radioactivity and mineralogy of placer concentrates from the Fortymile district, Alaska: (Unclassified)。 August 1950。

57B. White, $M_{0} G_{0}$. Trace elements reconnaissance in the Lower Coleen River Valley, Upper Yukon division, Alaska: (Unclassified). February 1950. $(\mathrm{C}=185)$.

57C. White, Mo Go, Radioactivity in the Pokpilak" gneissic granite, Mount Michelson area, northeastern Alaska: (Unclassified). January 1951. $(\mathrm{C}-195)$.

57D. Moxham, R. M. The occurxence of zeunerite in the Russian Mountains, Alaska, interim report: (Unclassified). February 1950 .

58. Conant, L。C.s Second interim report, black shale investigations (Chattanooga): (Secret). March 1949.

59. King, R. U. Reconnaissance investigations for uranium in the Colorado Front Range, 1947-1951.*

60. Grimaldi, F. S. ard Levine, Farry, The fluorimetric determination of aluminum in phosphate rock with 8-hydroxyquinoline: (Unclassified). August 1950.(B-992).

61. Wyant, $D$ 。 Go and Beroni, E。 Po, Reconnaissance for trace elements in North Dakoto, and eastern Montana: (Pt, I, Unclassified; Pt. 2, Confidential). February 1950. Issued in one part (Confidential) November 1949 .

62. Conant, I。 Co, Brown, Andrew, and Haas, Wo Ho, Chattanooga shale of the Eastern Highland Rim, Tennessee: (Confidential). August 1950。

63. Robeck, R. C. and Brown, Andrew, Black shale investigations, Block 3 , Tennessee: (Confidential). March 1950.

64. Robeck, R. C。 and Conant, I, C。, Reconnaissance search in parts of Kentucky, Tennessee, Indiana, Virginia, and Ohio for areas where uraniferous black shale may be mined by stripping: (Confidential). May 1951.

65. Nelson, Jo Mo, Prospecting for uranium with car-mounted equipment, a progress report: (Unclassified). July 1949, (B. 988- I; TIS)。

66. Davis, W。 E。 Swartz, I。 $H_{0}$, and Shuler, $R_{0} M_{0}, A$ preliminary geophysical investigation of carnotite deposits in Mesa County, Colorado:

(Official use only)。 October 1949. 
67. McKeown, F. A., Reconnaissance of radioactive rocks of Vermont, New Hampshire, Connecticut, Rhode Island, and southeastern New York: (Unclassified)。 June 1951. (TIS)。

68. Nelson, J. M. and Narten, P. F., Reconnaissance of radioactive rocks of Maine: (Unclassified). December 1951. (TIS).

69. Johnson, D. H., Reconnaissance of radioactive rocks of Massachusetts: (Unclassified). December 1951. (TIS).

70. Narten, P. F. and McKeown, F. A. Reconnaissance of radioactive rock of the Hudson Valley and Adirondack Mountains, New York: (Unclassified). May 1952. (TIS).

71. Hinrichs, E, N., The pegmatites of the Errington-Thiel mine, Elko County, Nevada: (Unclassified). February 1950. (OF).

72. Anderson, F. J.2 Reconnaissance of some geologic formations in southeastern Idaho, western Wyoming, and northern Utah: (Unclassified). January 1950.

73. West, $W . S$, and Benson, $P, D_{0}$, Reconnaissance for radioactive deposits on the Mountain View mining property and adjacent areas, Hyder district, southeastern Alaska.*

74A. Moxham, R。 M. and Nelson, A. E。 Trace Elements reconnaissance in the Jakolog Bay area, southern Alaska: (Unclassified). August 1950. $(\mathrm{C}-207)$.

75. White, Max G. and Stevens, John M., Reconnaissance for radioactive deposits in the Nixon Fork mining district, Medfra quadrangle, central A.laska, 1949: (Unclassified)。February 1953. (C-279; NSA).

76A. White, M. G., Examination for radioactivity in a copper-lode prospect on Ruby Creek, Kobuk River Valley, Alaska: (Unclassified). August 1950.

77. McKelvey, V. E., Relation of uranium and phosphate in the Phosphoria formation: (Confidential). January 1950.

78. Staff, Characteristics of radioactive carbonaceous and bituminous shales: (Confidential). Jamuary 1950.

79. Cathcart, J. B., Uranium-bearing sedimentary rocks in the land-pebble phosphate deposits of Florida: (Confidential). January 1950.

80. Fischer, R. P., Carnotite deposits of the Colorado Plateau: (Official use only). Jamuary 1950.

81A. Thurston, R. H. and Chace, F. M. Tin, copper, and uranium at Majuba HiIl, Nevada: (Unclassified). February 1950. 
82. Gott, G. B., Application of gamma ray logs of oil wells to the dis= covery of radioactive ore: (Unclassified). August 1949.

83. Stead, F. W. Progress on detection of radioactivity by alrbone equlpment: (Official use only). September 1949.

84. BeIl, $K_{0}$ G, and Rogers, A。 S., Experimental gammawray logging of drill holes in the Calamity area, Mesa County, Colorado: (Unclassified). February 1950 .

85. Cathcart, J. B. Distribution of uranium in the Florida phosphate field: (Confidential). August 1949.

86. Fischer, R. P. and Blackman, D. H., Geologic guides to carnotite deposits on the Colorado Plateau: (Unclassified). August 1949.

87. Bell, K. G. Semiquantitative determination of uranium and stratigraphic correlation by gamma way logging of drill holes in carnotite deposits: (Unclassified). August 1949.

88. Page, L. R。, Beryllium in Colorado: (Unclassified). March 1950. (J-77)。

89. Fetzer, W. G. Walters, E. E., and Fischer, R. P., Some considerations regarding potential production of uranium vanadium ore in Colorado, Utah, New Mexico, and Arizona: (Secret). 1948.

90. Page, I. R., The Geological Survey's beryliium program, fiscal 1948, an interim report: (Official use only). November 1948.

91. May, Irving and Fletcher, M. H., Preliminary report on a transmission fluorimeter for use in the fluorimetric method of analysis for uranium: (Official use only). November 1948.

92. Stieff, L. R。, Program of study for the carnotite ores of the Colorado Platea: (Unclassified). March 1949.

93. Brown, Andrew, Experimental adit in the Chattanooga shale: (Confidential). March 1949.

94. McKelvey, V. E. and Cathcart, J. B., Staff report on phosphates: Pt。 1, Florida phosphates; Pt。2, Progress report on the investigation of uranium in western phosphate field: (Secret)。 June 1949.

95. Cathcart, J. Bo, Characteristics of uranium-bearing sedimentary rocks in the land-pebble phosphate deposits of Florida: (Confidential). Ju1y 1949 .

96. Fischer, R. P. and Blackman, D. H., Progress report on geologic, mineral(Part 1). ogic, and geobotanical guides to ore in the carnotite deposits of the Colorado Plateau: Pt. 1, Geologic guides to carnotite deposits: (Unclassified). July 1949. 
96. Hawkes, H. E., Progress report on geologic, mineralogic, and geobotanical (Part 3). guides to ore in the carnotite deposits of the Colorado Plateau: Pt. 3, Geobotanical program for Colorado Plateau: (Unclassified). July 1949.

97. Staff, Tonnage and grade of slime ponds and washer debris areas, Florida phosphate field: (Secret). September 1949.

98. Grimaldi, F. S., Ward, F. N., and Kreher, Ruth, A direct quantitative fluorimetric method for the determination of small amounts of uranium in the field and laboratory: (Unclassified). June 1949. $(B=1006 *$ TIS $)$.

99. Randolph, R. B. and Grimaldi, F. S., The determination of phosphorus in rocks containing vanadium: (Unclassified). July 1949. (B-992).

100. Stewart, R. Ho, Preliminary results of prospecting of the "leached" zone over phosphate deposits in NW/ $\frac{1}{4}$ of Sec. 9, T. 3I S., R. 25 E., Polk County, Florida: (Official use only). December 1949.

101. Rabbitt, J.C., The first annual report of the Trace Elements Section for the fiscal year 1949: (Unclassified). January 1950.

102. Altschuler, Z. S. and Boudreau, C.E., A mineralogical and chemical study of the leached zone of the Bone Valley formation of Florida, a prow gress report: (Unclassified). December 1949.

103. Frondel, J. W. and Fleischer, Michael, A glossary of uranium and thoriumbearing minerals: (Unclassified). January 1950. (C-194).

104. Fletcher, M. H., May, Irving, and Slavin, Morris, A transmission fluorimeter for use in the fluorimetric method of analysis for uraniun: (Unclassified). August 1949. (B-1006\%, OF).

105. Levine, Harry and Grimaldi, F. S., Application of mesityl oxide to the determination of thorium: (Unclassified). February 1950. (B-1006*; TIS).

106. Stieff, $I_{0} R_{0}$, Girhard, $M_{0} N_{0}$, and Stern, T. W., Study of radioactive equilibrium in carnotite ores of the Colorado Plateau: (Unclassified). August 1949.

107. Murata, K. J., Cisney, E. A., Stieff, L. R., and Zworykin, E. V., Synthesis, base exchange, and photosensitivity of carnotite, tyuya munite, and related minerals: (Unclassified). August 1949. (J-74).

108. Stieff, L. R., Girhard, M. N., and Stern, T. W., A preliminary report on methods of determining the age of Colorado Plateau carnotite: (Unw classified). April 1950.

109. Fischer, R. P., The Uravan mineral belt: (Secret). February 1950. (TEI-109 revised--B=988 A; OF). 
110. Cater, F. W., Craig, I. C., and Phoenix, D. A., Progress of geologic studies, Colorado Plateau project: (Unclassified). February 1950.

111. McKelvey, V.E. and Swanson, R. W., Status of investigations of uranium in the Phosphoria formation, a preliminary report to the $\mathrm{AEC}$ :

(Secret). December 1949. (Official use only, 3-4-54)

112. Bush, A. L., Carnotite resources in the Charles T. area and vicinity, San Miguel County, Colorado: (Official use only). March 1950.

113. Trace, R。 D., Carnotite resources in the Radium group area, San Miguel County, Colorado: (Official use only). April 1950.

114. BeII, Henry, III, Carnotite resources of the Lower group of claims, San Miguel County, Colorado: (Official use only). April 1950.

115. Withington, C. F. and Bush, A. L., Carnotite resources of the Ellison and Burro claims, San Miguel County, Colorado: (Official use only). April 1950.

116. Bush, A. L., Hilpert, L. S., and Trace, R. D., Carnotite resources of the Georgetown group of claims, San Miguel County, Colorado: (Official use only). June 1950.

117. Stager, H. K., Carnotite resources of the Maverick group area, Mesa County, Colorado: (Official use only). June 1950.

118. Silverman, S. R., Fuyat, R. K., and Weiser, J. D., The quantitative determination of calcite associated with carbonate-bearing apatites: (Unclassified). August 1951. (J 88; OF; TIS; NSA).

119. Blackman, D. H., Geologic guides to prospecting for carnotite deposits on the Colorado Plateau: (Official use only). October 1951. (B-988-B).

120. Fletcher, M. H. and May, Irving, An improved fluorimeter for the determination of uranium in fluoride melts: (Unclassified). June 1950. ( $B=1006 *$, OF; TIS; NSA).

121. Gott, G. B. and Hill, J. W., Radioactivity in some oil fields of southeastern Kansas: (Unclassified). April 1951. (B-988=E).

122. Wyant, D. G., Sharp, W. N., and Sheridan, D. M., Uranium deposits in the Red Desert of the Great Divide Basin, Sweetwater County, Wyoming: (Pt. 1, Unclassified; Pt. 2, Official use only). November 1951. $(B-1009) \%$

123. Beroni, E. P. and Bauer, H. I., Jr., Reconnaissance for uraniferous lignites in North Dakota, South Dakota, Montana, and Wyoming: (Confidential). July 1952.

124. Wilmarth, V. R., Vickers, R, C., McKeown, F. A., and Beroni, E. P。, The uranium deposits at the Yellow Canary claims, Daggett County, Utah: (Pt. 1, Unclassified; Pt. 2, Official use only). September 1952. $(c-312) . *$ 
125. Sims, $P_{0} K_{0}$, Osterwald, F。 W., and Tooker, E。 Wo, Radioactive deposits in Eureka Gulch area, Central City district, Gilpin County, Colorado.*

126. Adams, J. W., Beryllium deposits of the Mount Antero region, Chaffee County, Colorado: (Unclassified). May 1951. (B-982-D).

127. Stieff, I. R。 and Stern, T. W. The preparation of nuclear-track plates and stripping films for the study of radioactive minerals: (Unclassified). August 1950。(J-101; OF).

128. Fleischer, Michael, An introduction to the geochemistry of gadolinium: (Unclassified). September 1950.

129. Stern, T. W., A catalog of study material of radioactive minerals: (Unclassified)。 October 1950。(OF; TIS; NSA).

130. Fletcher, $M_{0}$ H, A study of critical factors in the "direct" fluorimetric determination of uranium: (Unclassified). October 1950. $\left(B-1006^{\circ}\right.$ TIS; NSA).

130, addendum Fletcher, Mary H., Addendum to a study of critical factors in the "direct" fluorimetric determination of uranium: (Unclassified). April 1952.

131. McKelvey, V. E。, Potential by-product elements in the Phosphoria formation of the western states: (Unclassified). October 1950.

132. Jaffe, E. B., Abstracts of the literature on synthesis of apatites and some related phosphates: (Pt。 I, Unclassified; Pt。2, Secret). December 1950. (C-135; NSA).

133. Fletcher, M. H., May, Irving, and Anderson, J. W., The design of the Model V transmission fluorimeter: (Unclassified). December 1950. $(B-1006$; ; $;$ TIS; NSA).

134. Grimaldi, F. S. and Guttag, N. S., Short routine direct method for the fluorimetric determination of uranium in phosphate rocks: (Unclassified). December 1950. (B=1006)*

135. May, Irving and Fletcher, M. H。, A battery-powered fluorimeter for the determination of uranium: (Unclassified). December 1950. (B-1006; NSA).

136. Staatz, M. H., Wilmarth, V. R。, and Bauer, H. L., Jr., Radioactive fluorite in the Thomas Range, Juab County, Utah: (Pt. 1, Unclassim fied; Pt. 2, Official use only). January 1951. (B-1005)\% 
137. Warner, I. A, , Holser, W. To, Wilmarth, V。 Ro, and Cameron, E。 No, Nonpegmatitic resources of beryllium in the United States.*

138. Staatz, M。Ho and Trites, A。Fo, Jro, Geology of the Quartz Creek pegmatite district, Gunnison County, Colorado: (Pt. I, Unclassified; Pt。2, Official use only)。April 1952. (P-265; OF)。

139. Thurston, $W_{0} R_{0}$, Pegmatites of the Crystal Mountain district, Larimer County, Colorado: (Pt。 I, Unclassified; Pt。2, Official use only). ApriI 1952。(B-101I, OF)。

140. Trites, $A_{0} F_{0}, J r_{0}$ and Tooker, E。 Wo, Uranium and thorium deposits in eastacentral Idaho and southwestern Montana: (Pt. I, Unclassified; Pt. 2, Official use only). March 1952。(B-988-H; TIS)。

141. Cathcart, J。Bo, TiIIman, C. Go, and Dutro, H。 Bo, Reserves of phosphate in the land-pebble phosphate field, Hardee, Hillsborough, Manatee, Osceola, Pasco, and Polk Counties, Florida: (Official use only). January 1951; revised pages, September 1951.

142. Thompson, $M_{\circ} E_{0}$, Distribution of uranium in rich phosphate beds of the Phosphoria formation: (Unclassified). February 1951. (B-988-D; TIS; NSA)。

143. Waring, C.I。 and Anne11, C。S, A semiquantitative spectrographic method for the analysis of minerals, rocks and ores: (Unclassified). February 1951. (J-112; TIS)。

144. Phair, George and Onoda, Kiyoko, Hydrothermal uranothorite in fluorite breccias from the Blue Jay mine, Jamestown, Boulder County, Colorado: (Unclassified). March 1951. (J-80; OF; TIS; NSA).

145. Withington, C.Fo, Carnotite resources of the Upper group area, San Miguel County, Colorado: (Official use only). July 1951.

146. Stager, H. $K_{\circ}$, Carnotite resources of the Calamity group area, Mesa County, Colorado: (Official use only). June 1951.

147. Brymer, Leonid, Carnotite resources of Club Mesa, Montrose County, Colorado: (Confidential). November 1952.

148. Rabbitt, J。Cog Surmary of the research work of the Trace Elements Section, Geochemistry and Petrology Branch, for the period April 1, 1948-o-December 31, 1950: (Confidential)。 January 1951。 (OF; TIS; NSA)。

149. Norton, J.J., Beryliium resources of the world: (Confidential). June 1951。 
150. McKelvey, V。 E, Page, L。 R, Fischer, R。 $P_{0}$, and Butler, $A_{0}, P_{0}$, Jro, Domestic resources of uranium and thorium-a summary based upon investigations by the U. S。 Geological Survey: (Secret). April 1951.

151. Rabbitt, J. C., Summary of the research work of the Trace Elements Section, Geochemistxy and Petrology Branch, for the period January 1Mareh 31, 1951: (Unclassified)。 May 1951. (OF; TIS; NSA).

152. Cuttitta, Frank $A_{9}$ A photometric method for the estimation of the oll yield of oil shale: (Unclassified). May 1951. (B-992; OF; TIS: NSA).

153. Guttag, No S, and Grimaldi, F。 S, Fluorimetric determination of uranium in shales, lignites, and monazites after alkali carbonate separation: (Unclassified)。 JuIy 1951.

153A. Guttag, No So and Grimaldi, F, S, Fluorimetric determination of uranium in shales, lignites, and monazites after alkali carbonate separation: (Unclassified). October 1951。(B-1006* TIS; NSA)。

154. Finch, W. Io, Carnotite resources of part of Blue Mesa, Mesa County, Colorado: (Official use only). February 1952.

155. Lang, $A_{0} J_{0}, J x_{0}$ and Redden, J。A。, Geology and pegmatites of part of the Fourmile area, Custer County, South Dakota: (Pt, 1, Unclassified; Pt. 2, Official use only)。 March 1952. (C-245).

156. Granger, H. Co, Bauer, H. Io, Jro, Lovering, T。 Go, and Gillerman, Elliot, Uranium deposits in Grant County, New Mexico: (Pt, I, Unclassified; Pt。2, official use only)。 September 1952.

157. Granger, $\mathrm{H}_{0} \mathrm{C}$, and Bauer, $\mathrm{H}_{0} \mathrm{I}_{0}, \mathrm{Jr}$, Uranium occurrences on the Merry Widow Claim, White Signal district, Grant County, New Mexico: (Unclassified). November 1951。(C-189).

158. Wilmarth, $V 。 R$, and Johnson, $D_{0} H_{0}$, Uranophane at the Silver Cliff Mine near Lusk, Niobrara County, Wyoming: (Pt, 1, Unclassified; Pt。2, official use only). May 1952。(B-1009-A)*

159.

160. Cannon, H. L. , The effect of uranium-vanadium deposits on the vegetation of the Colorado Platea: (Unclassified). October 1951. (J-II).

161. Phoenix, D。 A。, Present and past ground-water conditions in the Morrison formation in southwestern Colorado and southeastern Utah: (Official use only). October 1952. 
162. Trace, R. D., Uranium and vanadium resources of the Slick Rock district, San Miguel County, Colorado: (Confidential). May 1952.

163. Brasher, G. Ko, Carnotite resources of Outlaw Mesa, Mesa County, Colorado: (Confidential). November 1952.

164. Be1I, Henry, III, Carnotite resources of the Legin Group area, San Migue1. County, Colorado: (Official use only). July 1952.

165. Stewart, Jo Ho, Carnotite resources of the Moon Mesa and Horse Mesa areas, Mesa and Montrose Counties, Colorado: (Official use only). March 1953.

166. Holser, $W_{0} T \circ$, Beryllium minerals in the Victorio Mountains, Luna County, New Mexico: (Unclassifled)。 January 1952。(J-49).

167. Rabbitt, JoCog Summary of the research work of the Trace Elements Secm. tion, Geochemistry and Petrology Branch, for the period January IJune 30, 1951: (Unclassified). September 1951.

168. Kaiser, $E_{0} P_{0}, K i n g, R_{0} U_{0}, W i l m a r t h, V . R \circ$, Stugard, Frederick, Jro, Wyant, $D_{0} G_{0}$, Gott, $G_{0} B_{0}$ g and others, Selected papers on uranium deposits in the United States: (Unclassified). May 1952. (C-220; $\mathrm{J}-43 ;-53 ;-54 ;-106 ;-122 ;=123 ;$ OF)

169. Lovering, $T$. $G$, Radioactive deposits of Nevada: (Pt, I, Unclassified; Pt. 2, Official use only)。 July 1953. (Bm1009):

170. Waters, $A_{0} C_{0}$, and Granger, $H_{0} C_{0}$, Volcanic debris in uraniferous sand. stones, and its possible bearing on the origin and precipitation of uranium: (Unclassified). August 1952. (C-224; NSA).

171. Thurston, R。 $\mathrm{H}_{0}$ and Trites, A。 F, Jrog The uranium, tin, and copper deposits at Majuba Hid, Pershing County, Nevada: (Pt。 1, Unclasified; Pt。2, Official use only). December 1952. (B-1009*\%

172. Wilmarth, $V 。 R$, and Johnson, $D_{0} H_{0}$, Preliminary reconnaissance survey for thorium, uranium, and rarewearth oxides, Bear Lodge Mountains, Crook County, Wyoming: (Official use only). April 1953.

173. King, R。U., Leonard, B。F。, Moore, F。 B。, and Pierson, Co T。, Uranium in the metal-mining districts of Colorado: (Unclassified). June 1952. (C-215; J-55).

174. Lovering, ToGo, Radioactive deposits of New Mexico,* 
176. Wilmarth, V。 。 and Vickers, $R, C_{0}$, The Robinson and Weatherly uraniferous pyrobitumen deposits near Placerville, San Miguel County, Colorado: (Pt。 I, Unclassified, Pt。2, Official use only). November 1952. (OF).

177. Armstrong, F。C., The Central City pitchblende area, Gilpin County, Colorado。*

178. Grimaldi, F。S, Summary of current U.S. Geological Survey chemical methods of uranium and thorium analysis: (Unclassified). October 1951。(B-1006*)。

179. Myers, A。 T。 and Barnett, P. R。, Contamination of rock samples during grinding as determined spectrographically: (Unclassified). March 1952. (TIS)。

180. Craig, L。 Co, Holmes, C。No, Cadigan, R。A., Freeman, V。 L., Mullens, T。E。s and Weir, G。 Wo, Preliminary report on the stratigraphy of the Morrison and related formations of the Colorado Plateau region: (Unclassified)。 November 1951.(B-1009*; TIS)。

181. Pietsch, Audrey and Grimaldi, F. So, The fluorimetric determination of uranium in nonsaline and saline waters: (Unclassified). May 1952. (B-1006*; TIS)。

182. Rabbitt, J。C., Summary of the research work of the Trace Elements Section, Geochemistry and Petrology Branch, for the period July 1-w September 30, 1951: (Unclassified)。November 1951. (TIS; NSA).

183. McKelvey, $V_{0} E_{0}$, Davidson, D。 Fo, O'Malley, F。W., Smith, L。 E。, Armstrong, F。Co, and Sheldon, R。P。, Stratigraphic sections of the Phosphoria formation in Idaho, 1947 48, Part I: (Orficial use only)。 December 1952. (C-208; OF)。

184. MeKelvey, V。E。, Smith, L。 E。, Hoppin, R。A。, and Armstrong, F。C。, Stratigraphic sections of the Phosphoria formation in Wyoming, 1947-48: (Official use only). December 1952. (C-210; OF).

185. McKelvey, $V_{0} E_{0}$, Smith, L。 E。, Kinney, $D_{0} M_{0}$, Huddle, J。W., Hosford, $G_{0} F_{0}$, Sears, $R_{0} S_{0}$, Sprouse, $D_{0} P_{0}$, and Stewart, $M_{0} D_{0}$, Strati graphic sections of the Phosphoria formation in Utah, 1947 48 : (Official use only). December 1952. (C-211; OF)。

186. Swanson, $R_{0} W_{0}$, Klepper, $M_{0} R_{0}$, Lowe1l, $W_{0} R_{0}$, Honkala, F。 S。, Cressman, $E_{0} R_{0}$, Bostwick, D。A. Payne, O.A., and Ruppe1, E. T。, Stratigraphic sections of the Phosphoria formation in Montana, 1947-48: (Official use only). December 1952。(C-209;-260; OF).

187. McKelvey, V。E。, Armstrong, F。C , Gulbrandsen, R。A。, and Campbell, R. Mo, Stratigraphic sections of the Phosphoria formation in Idaho, 1947 48, Part II: (Official use only).April 1953. (C-301; OF). 
188. OMalley, F. W. Davidson, D. F., Hoppin, R. A, and Sheldon, R. P., Stratigraphic sections of the Phosphoria formation in Idaho, $1947 \mathrm{~m}$ 48, Part III: (Official use only). April 1953. (C 262 ; OF).

189. West, W. S. and Benson, P. D., Reconnaissance for radioactive deposits in the vicinity of Ketchikan, Goddard Hot Springs, Chichagof, Funter Bay, and Juneau, southeastern Alaska, 1949.*

190. Moxham, $R, M_{0}$ and Nelson, $A, E_{0}$, Reconnaissance for radioactive deposits in the Iliamna Lake- Lake Clark region, southwestern Alaska: (Unclassified). April 1952. (C-207).

191. Moxham, R. M. and Nelson, A. E., Radioactive pegmatite minerals in the Willow Creek Mining district, southmentral Alaska: (Unclassified)。 January 1952. (C-184).

192. White, Max G. and Stevens, John Mo, Reconnaissance for radioactive deposits in the Rubym Poorman district, Ruby quadrangle, Alaska, 1949: (Unclassified). February 1953. (C=279; NSA).

193. White, M. Go and Stevens, Jo Mo, Radioactivity traverse along the Yukon River between Ft. Yukon and Ruby, Alaska, 1949.*

194. White, M. G. and Tolbert, G. E, Radioactive granite in the Miller House-Circle Hot Springs area, east-central Alaska: (Unclassified). February 1952.

195. Wedow, Helmuth, Jr. and Tolbert, G. E., Radioactivity at the Copper Creek copper lode prospect, Eagle district, east-central Alaska: (Official use only). September 1952.

196. Wedow, Helmuth, Jr. and Tolbert, G. E., Reconnaissance for radioactive deposits in the Fortymile district, eastocentral Alaska, 1949: (Un. classified). December 1953.

197. Wedow, Helmuth, Jro, Stevens, J. Mo, and Tolbert, G. E。, Reconnaissance for radioactive deposits in the Fairbanks and Livengood quadrangles, east-central Alaska, 1949: (Official use only). October 1953.

198. Bachman, G. O., Baltz, E. H., and O'Sullivan, R. B., Reconnaissance for uraniumbearing carbonaceous rocks in New Mexico, 1952: (Official. use only). March 1953.

199. McKelvey, V. E., Search for uranium in western United States: (Unclassi-fied). April 1953. (NSA).

200. Vickers, R. C. (compiled by), Bibliography of Geological Survey Trace Elements Reports: (Officialuse only). Wovernen 1951. 
201. Vickers, R. C. (compiled by), List of current and planned projects of the Trace Elements program, U. S。 Geological Survey: (Official use only). November 1951.

202. Vickers, R. C. (compiled by), Numerical list of U. S. Geological Survey Trace Elements Reports: (Official use only). December 1951.

203. Smith, J. Fo, Jro, Hinrichs, E. No, and Luedke, R, G., Progress report on geologic studies in the Capitol Reef area, Wayne County, Utah: (Unclassified). August 1952。 (TIS).

204. Witkind, I. J., Thaden, R. E., Johnson, D。 H., Claus, R, J., and Lough, C. F., Geologic investigations in the Monument Valley area, Apache and Nava jo Counties, Arizona.*

205. Benson, W. E., and others, Geologic mapping and study of the copperuranium deposits in White Canyon, San Juan County, Utah.*

206. Rabbitt, J. Co, Rubey, W. Wo, Butler, A. Po, Jx。, Lovering, T。 S., and McKelvey, V. E., A preliminary outline of desirable research on the geochemistry of uranium: (Unclassified). April 1949. (TIS).

207. Butler, A. Po, Jr., The Geological Survey's work on the geology of uranium and thorium deposits: (Unclassified). April 1952. (TIS; NSA).

208. McKelvey, V. E., Trace elements work of the Geological Survey: (Unclassified). December 1951. (TIS).

209. Cannon, R. S., Geological Survey's work on isotope geology of uranium and thorium and their decay products: (Unclassified). January 1952. (TIS).

210. Cuttitta, Frank, A volumetric method for the estimation of the oil yield of oil shale: (Unclassified). March 1952. (B-992; TIS).

211. Stead, F. W., The Geological Survey's work on development of prospecting tools, instruments, and techniques: (Unclassified). May 1952. (TIS).

212. Cathcart, J。 B. and Davidson, D. Fo, Distribution and origin of phosphate in the land-pebble phosphate district of Florida: (Unclassified). June 1952. (Jo14; TIS).

213. Gordon, $E_{0}$ D., Withington, $C . F_{0}$, and Dow, V. T. Practices and results obtained with sample collectors for wagon-drill cuttings: (Unclassim fied). January 1953. (TIS: NSA).

214. Jobin, D. A., Carnotite resources of the Dolores bench, Montrose County, Colorado.* 
215. Waring, C. I, and Annell, C. S, A semiquantitative spectrographic method for the analysis of minerals, rocks, and ores (II): (Unclassified). February 1952. (J-112; TIS).

216. Waring, C. I. and Worthing, Helen, A spectrographic method for determining trace amounts of lead in zircon and other minerals: (Unclassified). March 1952。(J-114; TIS)。

217. Huleatt, W. Po, Wagon-drill sampling by U. S. Geological Survey: (Unclassified). February 1952。(J-52).

218. Rabbitt, J.C., Summary of the research work of the Trace Elements Section, Geochemistry and Petrology Branch, for the period October 1-December 31, 1951: (Unclassified). February 1952. (TIS).

219. Grimaldi, F. S., May, Irving, and Fletcher, M. H., U. S. Geological Survey fluorimetric methods of uranium analysis: (Unclassified). April 1952. (C-199).

220. White, M. G. and West, $W_{0} S_{.}$, Reconnaissance for uranium in the Lost River area, Seward Peninsula, Alaska: (Unclassified). June 1952. $(\mathrm{C}-319) *$

221. West, W. S. and White, M. G., The occurrence of zeunerite at Brooks Mountain, Seward Peninsula, Alaska: (Unclassified). June 1952. $(C-214 ; O F)$.

222. Wyant, D. G., Sharp, W. N., and Rodríguez, Carlos Ponte, Radioactive source material in Los Estados Unidos de Venezuela: (Confidential). February 1953.

223. Cuttitta, Frank, The colorimetric determination of total iron with ow phenanthroline: a spectrophotometric study: (Unclassified). May 1952. (TIS).

224. Conant, L. C. and Swanson, V. E., Uranium content of Chattanooga shale in east-central Tennessee and southern Kentucky: (Confidential). October 1952.

225. Staatz, Mortimer, Norton, J. J., Page, L. R., Stephens, H. G., and Wilmarth, $V_{0} R_{0}$, Beryl resources of the Helen Beryl, Tin Mountain and Elkhorn pegmatites, Custer County, South Dakota.*

226. Sheridan, D. M., and others, Beryl deposits of the Peerless pegmatite, Pennington County, South Dakota.*

227. Granger, H。C., Uranium deposits of Arizona.* 
228. Moore, F. B. and Cavender, $W_{0} S_{0}$, Geology and uranium deposits of the Caribou area, Boulder County, Colorado.*

229. Walker, G。 W。 and Lovering, $T$, G。, Radioactive deposits in California,*

230. Lovering, T。 $\mathrm{G}_{0}$, Radioactive deposits of Utah.*

231. Sheridan, D。 Mo, Geology of the High Climb pegmatite, Custer County, South Dakota。* (B-1015)*

232. Gott, G. B。 and Erickson, R。 L。, Reconnaissance of uranium and copper deposits in parts of New Mexico, Colorado, Utah, Idaho, and Wyoming: (Pt。 I, Unclassified; Pt。2, Official use only). June 1952. (C-219).

233. Stugard, Frederick, $\mathrm{Jr}_{0}$, Pegmatites of the Middletown area, Connecticut.* (OF-map only).

234. Pierson, C. T。 and Singewald, Q. Do, Occurrences of uraniumbearing minerals in the St. Kevin district, Lake County, Colorado: (Pt, I, Unclassified; Pt. 2, Official use only). May 1953. (C-321) *

235. Moore, George W., Extraction of uranium from aqueous solution by coal and other materials: (Unclassified). June 1953.

236. Milkey, $R$ 。 $G$, A theoretical treatment of the absorption characteristics of the dithizone mixed-color system: (Unclassified). May 1952. (J-71; TIS; NSA)。

237. Conant, L. C., Origin of the Chattanooga shale: (Unclassified). July 1952. (J-14; OF; NSA)。

238. Zeller, $H_{0}$ D, Results of core drilling of uranium-bearing lignite de. posits in Harding and Perkins Counties, South Dakota, and Bowman County, North Dakota: (Confidential)。 October 1952.

239. Waring, C, I。 and Mela, Henry, Jro, The determination of small amounts of rare earths in phosphate rocks: (Unclassified). June 1952. $\mathrm{J}=113$; TIS)。

240. Trites, $A_{0} F_{0}, J_{0}$, Beroni, E。 $P_{0}$, and Benson, $W_{0} E_{0}$, Uranium and copper deposits at the Gonway and North Point claims, White Canyon area, San Juan County, Utah,* 
241. Vine, Jo Do, Bachman, $G_{0}$ O o, Read, C. Bo, and Moore, G。 Wo, Uranium bearing coal and carbonaceous shale in the La Ventana Mesa area, Sandoval County, New Mexico: (Official use only). January 1953.

242. Ha.11, M, L, and ButIer, A, P. Jro, Compilation of data on the uranium and equivalent uranium content of samples analyzed by U. S. Geological Survey during a program of sampling mine, mill, and smelter products: (Official use only). August 1952.

243. Stern, T。Wo and Weeks, A。 Do, Second occurrence of bayleyite in the United States: (Unclassifled)。 July 1952. (Jø97; NSA)。

244. Cook, Ko L。 and Moss, Co Ko, Geophysical observations in parts of the Grants district, McKinley County, New Mexico: (Pt. I, Unclassified; Pt。2, Official use only)。August 1952. (TIS; NSA)。

245. Milkey, $R_{0} G_{\circ}$, Methods of analysis used in the treatment of Colorado Plateau carnotite for age studies: (Unclassified). August 1952 . (TIS: NSA)。

246. Swanson, R。 Wog McKelvey, V。 $E_{0}$, and Sheldon, R。 P。 Progress report on investigations of western phosphate deposits:-(Pt。 I, Unclassified; Pt.2, Official use only)。 November 1952. (Cø297; OF)。

247. Phair, George, Radioactive Tertiary porphyries in the Central City dis trict, Colorado, and their bearing upon pitchblende deposition: (Unclassified)。 August 1952. (TIS: NSA)。

248. Piesson, $C_{0} T_{0}$ and Singewald, Q. Dog Resuits of reconnaissance for radio activity in parts of the Alma district, Park County, Colorado: (Pt. 1, Unclassified: Pt。 2, Official use only)。April 1953. (c-294)

249. Griffitts, W. $R_{0}$, Berylilum resources of the tin-spodumene belt, North Carolina: (Pt. I, Unclassified; Pt。2, Official use only)。 November 1952。 $(\mathrm{C}-309)$ *

250. Christman, R. A。, Heyman, A。M。, Dellwig, I。 Fog and Gott, G。 B. ghorium investigations 1950-52, Wet Mountains, Colorado: (Pt. I, Unclassi. fied; Pt。2, Official use only)。 February 1953. (C-290)。

251. Shawe, D。 R. Thorium resources of the Mountain Pass district, San Bernardino County, California: (Pt. I, Unclassified; Pt。2, Official use only). March 1953. (Part of P-261).*

252. Staatz, M。 Ho and Osterwald, F。W. Geology of the uraniferous filuorspar district, Thomas Range, Juab County, Utah.*

253. Wilmarth, $V$, R。, Geology and ore deposits of the Placerville area, San Miguel County, Colorado. * 
254. Stugard, Fo, Jro, Physical exploration for uranium during 1951 in the Silver Reef district, Washington County, Utah: (Pt. 1, Unclassified: Pt。2, Official use only). May 1953. (OF)。

255. Dings, M. Go and Schafer, Max, Radiometric reconnaissance in the Garfield and Taylor Park quadrangles, Chaffee and Gunnison Counties, Colorado: (Pt. I, Unclassified; Pt. 2, Official use only). February 1953. (TIS; NSA)。

256. Meschter, $D_{0} Y_{0}$, The geology and mineralogy of the $W_{0}$ Wilson mine near Clancey, Jefferson County, Montana: (Pt。 1, Unclassified; Pt。2, Official use only). March 1953.

257. Becraft, G. E。, Preliminary report on the Clancy Creek area, Jefferson City quadrangle, Jefferson County, Montana: (Official use only). March 1953.

258. Cressman, E。 $R_{0}$, Geology of the Dry Valley quadrangle, Idaho: (Un classified). August 1952. (B-1015*; OF)。

259. Meyers, W。 Bo, Geology and mineral deposits of the northwest quarter Willis quadrangle and adjacent Brown's Lake area, Beaverhead County, Montana: (Unclassified). August 1952。(OF).

260. Gulbrandsen, R。A。, McLaughlin, K。 $\mathrm{P}_{0}$, Honkala, F。 S。, Clabaugh, S。E。, and Krauskopf, $K_{0}$ Bo, Geologic map and structure sections of the Johnson Creek quadrangle, Caribou County, Idaho: (Unclassified). August 1952。(OF)。

261. Gillerman, Elliot and Whitebread, D。Mo, The U-bearing nickel-cobaltnative silver deposit in Black Hawk district, Grant County, New Mexico。*

262. Phair, George and Levine, Harry, Notes on the differential leaching of uranium, radium, and lead from pitchblende in $\mathrm{H}_{2} \mathrm{SO}_{4}$ solutions: (Unclassified). September 1952。(J-79; TIS; NSA)!

263. McKelvey, V. E., Swanson, R. Wo, and Sheldon, R. Po, The Permian phosphate deposits of western United States: (Unclassified). October 1952. (OF; NSA)。

264. Petersen, R。G., Areal distribution, thickness, and uranium content of the leached zone in the Clear Springs and Homeland areas, Polk County, Florida: (Official use only). September 1952.

265. Cathcart, J. B., Blade, L。 Vo, Davidson, D. Fo, and Ketner, Ko Bo, The geology of the Florida land-pebble phosphate deposits: (Unclassified). September 1952. (OF; NSA).

266. Altschuler, Z. S. , Summary of work on the mineralogy and petrography of southeast phosphates through Apxil 1952: (Confidential). November 1952. 
267. Tucker, Wo $P_{0}$ and Waring, C. L, The effect of ashing temperatures on the volatility of germanium in lignite samples: (Unclassified). September 1952。(TIS, NSA).

268. Stieff, L, Ro, Stern, $T$, Wo, and Milkey, $R$, Go, A preliminary deter mination of the age of some Colorado Plateau uranium ores by the lead uranium method: (Unclassified)。 January 1953. (C-271).

269. McKee, E。 D。 and Weir, G. Wo Terminology for stratification and cross stratification in sedimentary rocks: (Unclassified). September 1952. (J-63; NSA)。

270. Staff, Trace Elements research quarterly progress report, January 1 to Narch 31, 1952: (Pt. 1, Unclassified; Pt.2, Confidential). July 1952. (TIS; NSA).

271. McKelvey, V.E。, Cathcart, J.B., Altschuler, Z, So, Swanson, R。 W。, and Lutz, Katherine, Domestic phosphate deposits: (Unclassified). November 1952。 ( $\mathrm{J}=65$; OF; NSA)。

272. Hail, W。 J., Jro and Gill, JoR。, Radioactive carbonaceous shale and lignite deposits in the Goose Creek district, Cassia County, Idaho: (Official use only). January 1953.

273. Berman, Robert, A nomogram for obtaining percent composition by weight from mineral grain counts: (Unclassified). October 1952. (J I0; NSA)。

274. Stitch, J.N., Spectrographic identification of mineral grains: (Unclassified). October 1952。(C-234; NSA).

275. Thompson, M. E. Further studies of the distribution of uranium in rich phosphate beds of the Phosphoria formation: (Unclassified). Novem. ber 1952. (Baw 1000*; TIS; NSA).

276. Lovering, T. G., Radioactive iron oxides investigations progress report.*

277. Wilmarth, V. R. and Smith, I, E., Results of diamond drilling and geo. logic investigation of the Shirley May (Garo) deposit, Park County, Colorado: (Official use only). November 1952.

278. Riley, I. B, and Shoemaker, E. M。, Distribution of ore deposits and. spectrographic analyses of some rocks and ores on the Colorado Plateau: (Confidential). December 1952.

279. Shoemaker, $E_{0}$. M. and Luedke, R. G., Map of the uranium region of tho Colorado Plateau: (Unclassified). December 1952. (OF).

280. Staff, Trace Elements research quarterly progress report, April I to June 30, 1952: (Unclassified). August 1952. (TIS; NSA). 
281. Vine, J. D. and Moore, G. W., Reconnaissance for uranium-bearing carbonaceous rocks in northwestern Colorad.o, southwestern Wyoming, and. adjacent paxts of Utah and Idaho: (Unclassified). October 1952. (TIS; NSA).

282. Becraft, G. E., Preliminary report on the Comet area, Jefferson City quadrangle, Jefferson County, Montana: (Unclassified). December 1952. (C-277; OF).

283. McKay, E. J., Geology of carnotite-bearing sandstone in the Uravan and Gateway districts, Montrose and Mesa Counties, Colorado, and Grand County, Utah: (Official use only). January 1953.

284. Breger, I. A. and DeuI, $M_{0}$, Status of investigations on the geochemistry and mineralogy of uraniferous lignites. (Confidential). December 1952.

285. Weeks, Alice Dowse, Mineralogic study of some Jurassic and Cretaceous claystones and siltstones from western Colorado and eastern Utah: (Unclassified). February 1953。(TIS; NSA)。

286. Bell, Henry, III, Carnotite resources of the Spud Patch area, San Miguel County, Colorado: (Official use only). August 1953.

287. Finch, W. Io, Geology of the Shinarump No, I uranium mine, Seven Mile Canyon area, Grand County, Utah.* (OF).

288. Bush, A。 I. and Stager, H。 Ko, Appraisal of the accuracy of U. S. Ceological Survey estimates for uranium-vanadium deposits on the Colorado Plateau.*

289. Alvord, D。C., Carnotite resources of the San Miguel bench, Montrose County, Colorado**

290. Brew, D。A., Exploration for uranium deposits in Atkinson Mesa area, Montrose County, Colorado.*

291. West, W. S., Reconnaissance for radioactive deposits in selected areas of the Lower Yukon-Kuskokwim region, Alaska, 1952: (Unclassified). October 1953. ( $\mathrm{Cos} 328)^{*}$.

292. Nelson, A. E., West, W. So, and Matzko, J. Jo, Reconnaissance for radioactive deposits in selected areas of eastern Alaska, 1952.* 
293. Houston, J. R。, Velikanje, R。 So, Bates, R, Go, and Wedow, Helmuth, Jro, Reconnaissance for radioactive deposits in selected areas of south eastern Alaska, 1952。*

294. Kupfer, D。 H. , Geology of the Calamity Peak area, Custer County, South Dakota。*

295. Harrison, Jo $E_{0}$ and Wells, $J_{0} D_{0}$, Geology and ore deposits of Freeland: Lamartine district, Colorado.*

296. Dings, McClelland $G_{\circ}$, Radiometric reconnaissance near Montezuma, Summit County, Colorado: (Pt, 1, Unclassified; Pt, 2, Official use only). February 1953. (TIS; NSA)。

297. Bales, W。 E. and BelI, Henry, III, Geology of uranium deposits of FaII River County, South Dakota,*

298. Hill, J。Wo, Uraniferous asphalts in southwestern Oklahoma.*

299. Wilmarth, V. R。, Geology of Shirley May mine near Garo, Park County, Colorado.*

300. Wallace, J. H. and Blatcher, V. Ko (compiled by), Numerical list of U。 $\mathrm{S}$. Geological Survey Trace Elements Reports to September 15, 1952: (Official use only). November 1952.

301 Curtis, Diane and Houser, Shirley S. (compiled by), Topical index and bibliography of U. S。 Geological Survey Trace Elements and related reports: (Pt. 1, Official use only; Pt, 2, Unclassified). December 1952. (C-281; NSA).

302. Sheridan, $D_{0} M_{\circ}$, Collier, J. To, and Maxwell, C。 $H_{\circ}$, Geology of the Lost Creek schroeckingerite deposits, Sweetwater County, Wyoming,*

303. Vickers, R。 C., Geology of the Huron River pitchblende occurrence, Baraga County, Michigan。* 
304. Sims, P. K., Drake, A. A., and Moench, R. H., Preliminary geologic and vein maps of part of the Central City district, Gilpin and Clear Creek Counties, Colorado: (Unclassified)。June 1953. (OF).

305. Wells, John D。 and Harrison, J.E., Radioactivity reconnaissance of part of north-central Clear Creek County, Front Range, Colorado.*

306. Pierson, C. To, Weeks, W. Fo, and Kleinhampl, F。 Jo, Interim report on radiometric reconnaissance in the Red Mountain, Upper Uncompahgre, and nearby mining district, western San Juan Mountains, Colorado.*

307. Stieff, L, R. and Erickson, E。 S., Jr., An air concentrator for very low grade Colorado Plateau uranium ores: (Unclassified). January 1953. (NSA).

308. Beronig E. P. and McKeown, F. A., Reconnaissance for uraniferous rocks in northwestern Colorado, southwestern Wyoming, and northeastern Utah: (Pt, 1, Unclassified; Pt, 2, Official use only). July 1952. (TIS)*

309. Frondel, Judith $W_{0}$ and Cuttitta, Frank, Studies of uranium minerals: The status of billietite and becquerelite: (Unclassified). February 1953. ( $\mathrm{J}-39$; NSA).

310. Staff, Search for and geology of radioactive deposits, semiannual progress report June 1 to November 30, 1952: (Confidential-Restricted Data). December 1952.

311. Sims, Paul K. and Phair, George, Geology of the Copper King mine area, Prairie Divide, Larimer County, Colorado: (Pt. I, Unclassified; Pt. 2, Official use only). December 1952. (J.89; TIS; NSA).

312. Lowel1, Wayne $R_{0}$, Geologic map and structure sections of the southwest quarter Willis quadrangle, Beaverhead County, Montana: (Unclassified). March 1953. (OF).

313. Williams, Go A., Cadigan, R. A。, Albee, H. F。, and Stewart, J。H, Progress report on the stratigraphy of the Triassic and associated formations in part of the Colorado Plateau region: (Official use only). June 1953.

314. Berman, Robert, A mineralogic study of churn drill cuttings from a well through the Bone Valley formation, Hillsborough County, Florida: (Unclassified)。 February 1953. (NSA).

315. Love, J. D., Preliminary report on the uranium deposits in the Miller Hill area, Carbon County, Wyoming: Official use only). January 1953.

(Pt. 1, Unclassified: Pt。2, $(\mathrm{C}-278)$. 
316. Owens, Jo $P_{0}, B_{\text {erman }}, R_{0}$, and Altschuler, $Z_{0} S_{0}$, The occurrence of millisite and pseudowavellite in the leached zone at Homeland, Florida: (Unclassified). March 1953。(NSA).

317. McKeown, F。A。 and Klemic, Harry, Reconnaissance for radioactive materials in northeastern United States during 1952. (Pt. I, Unclassified: Pt. 2, Official use only). June 1953. (TIS)*

318. Rosholt, J。N $\mathbb{N}_{0}, \mathrm{~J} x_{0}, \mathrm{~A}$ quantitative radiochemical method for the deter mination of the major sources of natural radioactivity in ores and minerals: (Unclassified). April 1953. (TIS; NSA).

319. Smith, JoFo, and others, Progress report on geologic studies in the Capitol Reef area, Wayne County, Utah, 1953.*

320. Trites, $A_{0} F_{0}, J_{0}$ and Finnell, $T_{0} I_{0}$, Progress report on geologic studies in the White Canyon area, San Juan County, Utah, 1953.*

321. Trimble, $D, E$, and Lewis, $R_{0} Q_{0}$, Geologic studies in the Monument Valley region, San Juan County, Utah。*

322. Stieff, L。 R。 and Stern, $T$, Wo, The lead-uranium ages of some uraninite specimens from Triassic and Jurassic sedimentary rocks of the Colorado Platear: (Unclassified). April 1953. (J-100; NSA)。

323. Honkala, Fred S. Preliminary report on geology of the phosphate deposits in the Centennial Range, Montana Idaho: (Unclassified). May 1953. $(\mathrm{J}-51 ; \mathrm{OF} ; \mathrm{NSA})$.

324. Portnov, A. Io, The use of aromatic compounds of arsenic in chemical analysis, Part I (translated by Skitsky, V, Lo): (Unclassified)。 April 1953. (TIS)。

325. Blatcher, Virginia $K_{\circ}$ and Wallace, Jane $H$. (compiled by), Numerical list of U.S.Geological Survey Trace Elements Reports to April 30, 1953: (Official use only). May 1953.

326. Cuttitta, Frank and Kinser, Charles $A_{\circ}$, An improved tubular electric furnace for the closed-tube distillation of oil from oil shale: (Unclassified). May 1953. (TIS; NSA)。

327. Frondel, Clifford, Hydroxyl substitution in thorite and zircon: (Unclassified)。 May 1953。( $\mathrm{J}-37$; NSA)。

328. Finch, W. Io, Resource appraisal of uranium deposits in pre-Morrison formations of the Colorado Platea o an interim report: (Pt, I, Unclassified; $P t 。 2$, Secret). May 1953。 (J-3l; TIS; NSA)。 
329. Sakakura, A. Y., A note on the transient gas flov problem: (Unclassified). June 1953. (NSA).

330. Staff, Search for and geology of radioactive deposits, semiannual progress report, December I, 1952 to May 31, 1953: (Unclassified). June 1953. (TIS; NSA)。

331. Staff, Search for and geology of radioactive deposits, semiannual progress report, classified data, December 1, 1952 to May 31, 1953: (Confidential). June 1953.

332. Masursky, Harold, Pipiringos, G. No, and Gower, H. D。, Results of exploratory core drilling for uranium-bearing coal in the northern part of the Red Desert area, Sweetwater County, Wyoming: (Official use only). May 1953.

333. Flanagan, F. J. and Senftle, F. E。, Tables for the calculation of radioactive equilibrium from Bateman's equation: (Unclassified). JuIy 1953. (NSA).

334. Weeks, A. D. and Thompson, M. E., Identification and occurrence of uranium and vanadium minerals from the Colorado Plateaus: (Unclassified). April 1953. (NSA).

335. Weeks, A. D., Cisney, E, A, and Sherwood, A. M, Montroseite, a new vanadium oxide from the Colorado Plateaus: (Unclassified). June 1953. ( $\mathrm{J}=118$; NSA).

336. Vine, J. $D_{0}$ and Flege, Robert $F_{0}, J r_{0}$, Reconnaissance during 1952 for uraniumbearing carbonaceous rocks in parts of Colorado, Utah, Idaho, and. Wyoming: (Unclassified), June 1953. (NSA).

337. Moore, G. W. and Stephens, J. Go, Reconnaissance for uranium-bearing carbonaceous rocks in California and adjacent parts of Oregon and Nevada: (Unclassified). June 1953. (C-313\%, NSA).

338. Zeller, H. D. and Baltz, E.H., Jro, Uranium-bearing copper deposits in the Coyote district, Mora County, New Mexico: (Unclassified). May 1953.

339. MapeI, W. J. and Hail, W. J., Jr., Uraniumbearing carbonaceous shale and lignite in the Goose Creek district, Cassia County, Idaho, Boxelder County, Utah, and Elko County, Nevada: (Official use only). June 1953.

340.

341. Mullens, T. E, ancfreemen, W. L., Lithotacies of the Salt Wash menber of the Morrison Pornation.* (J-73). 
342. Black, R. A. A magnetic investigation of the Round. Mountein stock, Castle Valley, Utah. *

343.

344.

345. Troyer, M。 I. McKay, E。 Jog Soister, P. E。, and Wallace, Stewart R。, Summary of investigations of uranium deposits in the Pumpkin Buttes area, Johnson and Campbell Counties, Wyoming: (Pt. I, Unclassified; Pt. 2, Official use onIy). JuIy 1953.

346. Freedman, Jacob, Petrology and mineralogy of some radioactive Tertiary intrusive rocks from the northern Black Hills, South Dakota。*

347. Welch, Stewart $W_{\text {. }}$ Radioactivity of coal and associated rock in the coal fields of eastern Kentucky.*

348. Welch, Stewart $W_{0}$, Radioactivity of coal and associated rocks in the anthracite fields of eastern Pennsylvania.*

349. Overstreet, $W_{0} C_{0}$, Theobald, $P_{0} K_{0}, J_{0}$, White, $A_{0} M_{0}$, Cuppels, No P., Caldwell, D. Wo, and Whitlow, JoWog Progress report of south= eastern monazite exploration, 1952: (Official use only). April 1953.

350. Hill, Jo Wo Summary of reconnaissance for radioactive materials in the south-central states, *

351. Sharp, $W_{0} N_{0}$ and Cavender, $W_{0}, S_{0}$, The geology and vein deposits of the Lemhi Pass area, Lemhi County, Idaho, and Beaverhead County, Montana。*

352. Johnson, $H_{0} \mathrm{~S}_{2}, \mathrm{Jr}_{0}$, Reconnaissance for uranium in the southeastern states, 1953 * 
353. Olson, J. C. and Wallace, S。 R., Thorium in the Powderhorn district, Gunnison County, Colorado.*

354. Christman, R. A, and others, Wet Mountain thorium investigations, 1952-54, Fremont and Custer Counties, Colorado**

355. Page, $I_{0} R_{0}$, and others, Black Hills uranium deposits, South Dakota。*

356.

357.

358.

359.

360. Cheney, T. M., Smart, R. A., Waring, R. G., and Warner, M. A., Stratigraphic sections of the Phosphoria formation in Utah, 1949-1951: (Official use only). July 1953. (C-306).

361. Cressman, E. R०, Wilson, W. H., Tandy, C. W., and Carmoe, W. J., Stratigraphic sections of the Phosphoria formation in Montana, 1949-1950, Part I: (Official use only). July 1953. (C-302).

362. Swanson, R. W., Cressman, E. Ro, Jones, R。 S., and Replogle, B. Ko, Stratigraphic sections of the Phosphoria formation in Montana, 1949-1950, Part II: (Official use only). July 1953. (C-303).

363. Sheldon, R, P., Waring, R。 Go, Warner, M。 A。, and Smart, R。A., Stratigraphic sections of the Phosphoria formation in Wyoming, 1949-1950: (Official use only). July 1953. (C-307).

364. Sheldon, R。 P., Warner, M。A., Thompson, M. E., and Peirce, H。 W。, Stratigraphic sections of the Phosphoria formation in Idaho, 1949, Part I: (Official use only). July 1953. (C-304).

365. Davidson, D。F., Smart, R. A, Peirce, H. W., and Weiser, J. Do, Strati= graphic sections of the Phosphoria formation in Idaho, 1949, Part II: (Official use only). July 1953. (C-305). 
366. Swanson, $V_{0} E_{0}$, Results of 1952 sampling of Chattanooga shale in Tennessee and adjacent states。*

367. Frondel, Judith $W$, and Cuttitta, Frank, Studies of uranium minerals: An alteration product of ianthinite: (Unclassified). August 1953.

368. Evans, Howard T. , Jro and Block, Stanley, The crystal structure of montroseite, a vanadium member of the diaspore group: (Unclassi. fied.). October 1953. (J-26)。

369. Kostyleva, E. E, On metamictic disintegration of the zircon group of minerals (translated by Taisia Stadnichenko): (Unclassified). September 1953。 (TIS) ${ }^{*^{2}}$

370. Kinser, Charles $A_{0}$, The model VI transmission fluorimeter for the determination of uranium: (Unclassified). October 1953.

371. Kellagher, Richard, A multiple cone-splitter for rapid sampling in the laboratory: (Unclassified). October 1953.

372. Breger, I0 Ao, Meyrowitz, Robert, and Warr, JoJ., Jro, Extraction of uranium from the Red Desert coal of Wyoming: (Unclassified). December 1953.

373. Milkey, Robert G., Stability of metallic ions in dilute solution: (Unclassified). November 1953.

374. Senftle, F. E., Farley, T。A., and Stieff, I. R., Theoretical alpha star poprlations in loaded nuclear emulsions: (Unclassified). November 1953.

375. Peterson, J。A. Gosman, R。 Fog and Swanson, $R_{0} W_{0}$, Stratigraphic sections of the Phosphoria formation in Montana, 1951: (Official use only)。 October 1953。(Cos26)*

376. Smart, R。 Ao, Waring, $R$ 。 Go, Cheney, $T$, Mo, and Sheldon, R。 Pog Stratigraphic sections of the Phosphoria formation in Idaho, 1950 51:

(Official use only). October 1953. (C-327):

377. Cheney, To Mo, Sheldon, R。 Po, Waring, $R_{0} G_{0}$, and Warner, Mo Ao, Stratio graphic sections of the Phosphoria formation in Wyoming, 1951: (official use only). November 1953。(C-324)*

378. Sheldon, R。 Po, Cressman, E。 Ro, Carswell, L。 Do, and Smart, R。 A。, Stratigraphic sections of the Phosphoria formation in Wyoming, 1952: (Official use only). November 1953. (C-325)\%

379. Levine, Harry, Rowe, Jo Jo, and Grimaldi, F. S., The molybdenum blue reaction and the determination of phosphorus in waters containing arsenic, silicon, and germanium: (Unclassified). November 1953. 
380. Moxham, R. M., Walker, G. W. and Baumgardner, I. H., An investigation of airborne radioactivity anomalies in the Rock Corral area, San Bernardino County, California.*

381. Duncan, Donald C. (compiled by), Reconnaissance investigations for uranium in black shale deposits of the western states during 1951 and 1952.*

382. McKeown, F. A., Klemic, H., and Choquette, P. W., Occurrencescof uretioum at Clinton, Hunterdon County, N. J.*

383. McKeown, F。A. and Klemic H., Rare earth-bearing apatite at Minevilie, Essex County, N. Y.*

384. Vickers, R. C., Geology and monazite deposits of the PaImer area, Marquette County, Michigan.*

385. Kazakov, A. V., The fluorapatite system of equilibria in the conditions of formation of sedimentary rocks (translated by V. L. Skitsky).*

386. Kazakov, A. V. and Sokolova, E. I., Conditions of the formation of fluorite in sedimentary rocks (translated by V. I. Skitsky).*

387. Moxham, R. M., Airborne radioactivity surveys for phosphate in Florida.*

388. Breger, I. A., Meyrowitz, Robert, and. Deul, Maurice, Effects of des tructive distillation on the uranium associated with selected naturally occurring carbonaceous substances。*

389. Breger, I. A., Deul, Maurice, Meyrowitz, Robert, and Rubinstein, Samuel, Mineralogy and geochemistry of a uraniferous coal from the Red. Desert area, Sweetwater County, Wyoming.* 
390. Staff, Geologic investigations of radioactive deposits, semiannual progress report, June t to November 30, 1953: (Unclassified). December 1953。 (TIS)。*

391. Staff, Geologic investigations of radioactive deposits, semiannual progress report, classified data, June 1 to November 30, 1953: (Confidential-Restricted Data)。 December 1953.

392. Singewald, Quentin D., Search for radioactive intrusive rocks in New Jersey, New York, and New England。*

393. Weeks, $A_{0} D_{0}$. Thompson, M。 E。, and Sherwood, A。 Mo, Navajoite, a new vanadium oxide from Arizona。*

394. Catheart, J. $B_{0}$, The aluminum phosphate zone in the Peace River area, landwpebble phosphate field, Florida.

395.

396.

397.

398.

399.

400. Wallace, Jane E., Blatcher, Virginia $K_{0}$, and Smith, Harriet $B_{0}, U_{0} S_{0}$ Geological Survey Trace Elements anc related reports through 1953: (Official use only). January 1954.

401. Senftie, F. E. and Champion, W. Ro, Table for simplifying calculations of activities produced by thermal neutrons.* 


\section{0}

402. Bracken, J. T. and Senftle, F. E., Change of the isotopic abundance ratio within a sphere due to diffusion.*

403. Wilson, E. E., Rhoden, V. C., Vaughn, W. W., and Faul, Henry, Portable scintillation counters for geologic use.*

404.

405.

406.

407.

408.

409.

410.

411.

412.

413.

414. 


\section{TRACE ELEMENTS MEMORANDUM REPORTS}

1. Gott, G。 B。 Investigation of radioactive springs near Jamestown Colorado: (Official use only). November 1948.

IA. Gott, G. B., Radioactive springs near Jamestown, Colorado: (Official use only). November 1948.

2. Wyant, $D$. Go, Majuba Hill mine, Pexshing County, Nevada, preliminary report: (Official use only). November 1948.

2A. Wyant, D。Go, Majuba Fill mine, Pershing County, Nevada: supplement to preliminary report: (Official use only). November 1949.

2B. Wyant, $D$. Go, Na fuba Hill mine, Pershing County, Nevada: supplement to preliminary report: (Official use only). February 1949.

3. King, R。 U。, Josie Bishop claims, Nojave, California, report of reconw naissance examination: (Official use only). January 1949.

4. King, R. U. , Schmittmitt property, San Diego County, California: (Official use only). Jamuary 1949.

5. King, R. U. Radicactivity in the Jo Reynolds mine, Clear Creek County, Colorado: (Pt. 1. Unclassified; Pt.2, Official use only). Jan uary 1951.

6. Hanley, E。 So, Colden Cycle tailings dump, Colorado Springs, Colorado: (official use only). January 1949.

7. Granger, E. Co and Beroni, E。 Po, Uranium occurrences in the White Canyon area, San Juan County, Utah: (Pt. 1, Unclassified; Pt。2, Official use only). December 1950.

7A. Fischer, $R$ 。 $P$ 。 and King, $R$, Uo, Investigation of uranium deposits in White Canyon, San Juan County, Utah: (Confidential). November 1948.

8. Wyant, D. Go, The Wheelman Tunnel, Boulder County, Colorado: (Officlal. use onIy). May 1949.

9. Wyant, D. Go, Treasure Hill area, Iarimer County, Colorado: (Orficial. use only). Apri1 1949. (TIS; NSA).

9A. Wyant, D。Gog Spaulding-Woodhams scheelite prospects, Iarimer County, Colorado: (Official use only). June 1949.

10. Wyant, D. G. Lost Creek (Wamsutter) schroeckingerite deposit, Sweet: water County, Wyoming: (Official use only). December 1948. (TIS).

10A. Wyant, D. G. Lost Creek schroeckingerite deposit, Sweetwater County, Wyoming: (Unclassified). March 1950. 
11. King, R. U. and Roberts, W. A., Yerington property, Anaconda Copper Mining Company, Lyon County, Nevada: (Official use only). July 1949.

12. King, R. U. and Roberts, W. A., Henebergh Tunnel, Round Mountain, Nye County, Nevada: (Official use only). July 1949.

13. King, R. U., Vein deposits of uranium at the Caribou mine, Boulder County, Colorado: (Official use only). June 1950. (TIS; NSA).

14. Wyant, D. Go, Live Oak Tank area, Joshua Tree National Monument, Riverside County, California: (Official use only). June 1949.

15. Wyant, D. G。, Marshall Ranch, Beaumont, Riverside County, California: (Official use only). June 1949.

16. Wyant, D。 Go, The Wesley R。Collins property, Costa Mesa, Orange County, California: (Official use only). August 1949.

17. Wyant, D。 G, The Kramer Hills area, San Bernardino County, California: (Official use only). August 1949.

18. Laurence, R。A., Prospects of Wm。S. King, Newton County, Arkansas, report of reconnaissance examination: (Official use only). May 1949.

19. McKeown, F. A., Preliminary report of uranium deposits near Mauch Chunk, Pennsylvania: (Official use only). June 1949.

20. Granger, H. C。 and Beroni, E。 P., Cook property, Jefferson County, Colorado: (Unclassified). February 1950.

21. Overstreet, $W_{0} C_{0}$, McKelvey, V. E, and Houser, F。 No, Proposed investigations of the Southeastern monazite deposits: (Unclassified). June 1951.

22. King, $R$. U., A radiometric traverse at the Apex claims (Bates Creek), Gilpin County, Colorado: (Unclassified). August 1950.

23. Mertie, J. B., Jr。, Heavy minerals in the Pleistocene terrace deposits of South Carolina and Georgia: (Unclassified). June 1951.

24. King, R. U. and Granger, H. Co, Torbernite occurrence at the Robineau claims, Clear Creek County, Colorado: (Pt. I, Unclassified; Pt. 2, Official use only). June 1950. (TIS; NSA).

25. Beroni, E. P., Granger, H. Co, and King, R。 U。, Radiometric examination of the Williamson and General Chemical fluorite deposits, Jamestown district, Boulder County, Colorado: (Official use only). November 1950 .

26. Anderson, F. J., Radiometric reconnaissance in the vicinity of Salmon, Idaho: (Unclassified). August 1950. 
27. Gott, G。Bo, Barbers Hill oil field, Chambers County, Texas: (Official use only). December 1949.

28. Gott, G. Bo, Uranium-bearing black shales and stylolite fillings in Spergen limestone, Bussen's Quarry, Ste。Genevieve, Missouri: (Unclassified)。 March 1950。

29. Adams, Jo Wo and King, R。 U., Pitchblende occurrence at the Sunshine mine, Shoshone County, Idaho: (Unclassified). August 1950.

30. Vhay, Jo So, Reconnaissance examination for uranium at six mines and properties in Idaho and Montana: (Unclassified). November 1950. (TIS)。

31. Klepper, M. Ro, FortyaNiner, King Solomon Ridge, and West End claims near Clancy, Jefferson County, Montana: (Unclassified). August 1950. (OF; TIS; NSA)。

32. Granger, $H_{0} \mathrm{C}$. and Bauer, H. Io, Jro, The Eureka and Happy Landing (Cooper-Sands) groups of claims, Uintah County, Utah-ma preliminary report: (Pt. 1, Unclassified; Pt. 2, Official use only). May 1950.

33. Granger, $H_{0} \mathrm{C}$. and Bauer, $\mathrm{H}_{\circ} \mathrm{L}_{0}, \mathrm{Jr}, \mathrm{g}$, Preliminary examination of uranium deposits near Marysvale, Piute County, Utah: (Pt. I, Unclassified; Pt。2, Official use only). September 1950.

34. White, Wo So, Radiometric scanning of collections of Keweenawan rocks of the Michigan copper district: (Unclassified). August 1950.

35. Sharp, W. No, Recommendations for drilling the bastnaesite deposits, Birthday claims, San Bernardino County, California: (Unclassified)。 May 1950。

36. Wilmarth, V. Ro, Uranium deposit in the Sheeprock Mountains, Tooele County, Utah: (Official use only). May 1950.

37. Staff, Memorandum discussing some considerations of the production potential of vanadium and uranium ore in the Colorado Plateau and related mill capacity: (Secret)。 April 1947.

38. Fischer, R. P. and Butlex, $A_{0} P_{0}, J x_{0}$, Memorandum recommending physical exploration and geologic studies in the Colorado Plateau uranium region: (Secret). April 1947.

39. Butler, A, Po, Jro, Memorandum on thorium resources: (Secret). June 194\%

40. Nolan, T. B., Investigation of the rare-element content in mill and smelter products and in raw materials planned for fiscal year 1948: (Confidential)。 JuIy 1947.

41. Butler, A. Po, Jro, Tailing losses in Idaho placer operations: (Official use only). July 1947。 
42. Butler, A. P., Jr., Memorandum on ahalysis of water samples from the Salton Sea, California: (Confidential). July 1947.

43. Hendricks, T. A., Shale of approximately 0.009 percent uranium content in eastern Tennessee with regard to tomnage, grade and some factors relative to mining: (Confidential). August 1947.

44. Hendricks, T. A., Status of Geological Survey studies of Florida phosphate and plans for additional work: (Secret). August 1947.

45. Hendriciss, T. A., Status of current monazite investigations by the Geological Survey: (Secret). August 1947.

46. Rabbitt, J. C., Thorium in Florida phosphate rock: (Secret). August 1947.

47. Hendricks, T. A., Best site for black shale mining on the basis of current data: (Secret). September 1947.

48. Fischer, R. P., Recommendations for exploration on the Colorado Plateau of areas favorable for carnotite deposits: (Official use only). August 1947. (Official use only, $1-20-54$ )

49. Stead, F.W., Available data on the content of radioactive elements in recent marine sediments and sea water: (Confidential). December 1947.

50. Rabbitt, J. C., Interim report on thorium-bearing limestone from Great Slave Lake, Canada: (Secret). December 1947.

51. Nolan, T. B., Investigation of heliumwearing gases and related rocks: (Confidential). Januery 1948.

52. Stead, F.W., Investigation of gamma-ray well logs: (Confidential). February 1948.

53. Carr, W. J., Reconnaissance of the Green River oil. shales: (Confidential). March 1948.

53A. Staff, Results of radioactivity determinations on Green River oil shale: (Confidential). August 1948.

54. Wyant, D. G. Investigation of the Staats fluorite mine, Utah: (Secret). March 1948.

55. Nolan, T. B., Summary of results of investigation of copper ores for radioactivity and status of current work: (Confidential). March 1948.

56. Staff, Monazite in concentrates from Idaho placer operations: (Unclassified). March 1948.

57. Stieff, I. R., Carnotite mineralogical research: (Confidential). April 1948. 
58. Nolan, To Bo, Occurrence of uranium in Nevada, memorandum to AEC (AEC-218/8): (Secret). Apri1 1948. (Declassified, 4-6-54)。

59. Staff, Radioactivity of recent sediments, salt and fresh water: (Confidential)。 May 1948.

60. Carr, W. J., Uranium deposit in Moffat County, Colorado: (Unclassified). May 1948.

61. Nolan, $T$ 。 $B_{0}$, Mill sampling program, memorandum to AEC (AEC-274/8): (Confidential). June 1948。

62. Nolan, To Bo, Status of the Northwest Phosphate project with respect to areas for intensive exploration: (Secret). June 1948.

63. Brown, Andrew, Experimental drilling in Chattanooga shale: (Secret). July 1948。 (Declassified, 3-4×54)

64. Staff, Some factors related to western phosphate development: (Secret). June 1948 .

65. Staff, Western phosphate program, sampling and mill studies: (Secret). August 1948.

66. Keiser, H。D。g Zirconium, memorandum to AEC: (Secret). August 1948.

67. Kinney, Do Mo, Investigation of reported uranium occurrence near Beaumont, California: (Unclassified). August 1948.

68. Stieff, I。 Ro, A progress report on some methods of study of the minw eralogy of the Colorado Plateau carnotites: (Unclassified). September 1948.

69. Staff, Beryl deposits of the Mt. Antero region, Chaffee County, Colorado: (Unclassified)。 September 1948.

70. Staff, Samples for metallurgical testing from the Anaconda Copper Mining Company's phosphate mine at Conda, Idaho: (Confidential). October 1948.

71. Guinan, Wo A, Status of mill products and raw materials project: (Cor. fidential)。 October 1948。

72. Schaller, Wo T., Beryl, preliminary statement: (Unclassified). November 1948。

73. Staff, Preliminary notes on distribution of uranium in the Florida pebble phosphate field and suggestions for study and sampling: (Confidential). January 1949.

74. Stieff, I。 Ro, Use of isotopes in geological investigations: (Unclassified). March 1949. 


\section{6}

75. Staff, Geological work of the Geological Survey for the Atomic Energy Comission that would be of special interest to petroleum geologists: (Official use oniy). March 1949.

76. Butler, A. P., Jr., Metallurgical research on berylliumwbearing rocks other than pegmatites: (Official use only). April 1949.

77. Hilpert, I. S. and Fischer, R. Po, Problems relating to ore recently discovered on Outlaw Mesa: (Confidential). April 1949.

78. Staff, Extent of investigations by the Geological Survey of various types of materials suggested by Mr.Wallace $\mathrm{E}$. Pratt, consultant to the Atomic Energy Commission: (Confidential). May 1949.

79. Staff, Carnotite deposits on government-owned claims, Calamity Mesa, Mesa County, Colorado: (Unclassified). May 1949.

80. Trace, R. Do, Results of drilling on the Radium group and associated claims near Egnar, San Miguel County, Colorado: (Confidential). March 1949.

81. Nolan, T. B., Highlights of the Geological Survey's program for the Atomic Energy Commission in fiscal year 1949: (Secret). August 1949.

82. Hilpert, I. So, Additional drilling on the Upper group and on the Ellison and Burro claims, San Miguel County, Colorado: (Unclassified). July 1949.

83. Staff, A tentative estimate of tonnage and grade of the leached zone and slime ponds in the Florida phosphate field: (Confidential). September 1949.

84. Stead, F. W., Evaluation of ratemeter type 1011: (Unclassified). September 1949.

85. Cathcart, J.B., Results of mine sampling program, Florida pebble phosphate field: (Secret). October 1949.

86. Guinan, W. A., Record of spectrographic cobalt (CoO) analyses of samples collected under the Mill and Raw Materials Sampling Project:

(Official use only). October 1949; supplemental list, March 1950.

87. Staff, Progress on airborne radiation detection: (Unclassified). December 1949.

88. Staff, Progress on carborne radiation detection: (Unclassified). December 1949.

89. Altschuler, Z. S., Progress on Florida phosphate mineralogy: December 1949. 
90. Stieff, $I_{0} R_{0}$, Progress on carnotite mineralogy: December 1949。

91. Staff, Summary of Alaskan reconnaissance investigations in the 1949 field season and proposals for field season of 1950. (Unclassified). December 1949.

92. Staff, Progress on Barnaby gammaray logging: December 1949.

93. Staff, Gamma-ray well logs, progress report: January 1950。

94. Botinelly, Theodore, Northwest phosphate mineralogy, progress report: (Unclassified)。 January 1950。

95. Botinelly, Theodore, Shale mineralogy, progress report: (Unclassified)。 January 1950.

96. Staff, Wamsutter (Red Desert) area, Wyoming, progress report: (Unclassified)。 January 1950。(OF; TIS; NSA)。

97. Staff, Colorado Front Range area, progress report: (Unclassified)。 January 1950. (OF; TIS; NSA)。

98. Altschuler, $Z_{0} S_{0}, A$ progress report on the Geological Survey's work in determining the nature of the phosphate in the washer plant waste slimes from the Florida phosphate deposits: (Unclassified). January 1949.

99. Phoenix, $D_{0} A_{\circ}$, Preliminary plans for groundwater studies: (Official use only). December 1949.

100. Joesting, H. Ro, Recommendation for geophysical investigation in the Colorado Plateau: (Unclassified)。 February 1950。

101. Blackman, $D_{0} H_{0}$, Geologic guides to carnotite deposits, progress report: (Unclassified)。 March 1950。

102. King, $R_{0} U_{0}$, Investigations in the Wood mine, Colorado: (Unclassified). February 1950. (TIS; NSA)。

103. Stager, H. Ko, Results of diamond-drill exploration in 1949 and plans for additional drilling on Outlaw Mesa and vicinity, Mesa County, Colorado: (Official use only). February 1950.

104. Thurston, W。 R。, Exploration of the Buckhorn mica mine, Larimer County, Colorado: (Unclassified). April 1950。(OF)。

105. Thurston, $W_{0} R_{0}$, Exploration of the Hyatt pegmatite, Larimer County, Colorado: (Unclassified). June 1950。(OF). 
106. Thurston, W. R., Exploration of the Big Boulder prospect, Larimer County, Colorado: (Unclassified). August 1950. (OF).

107. NcNeal, R. P., Reconnaissance in oil fields in Lea County, New Mexico: (Unclassified). June 1950.

108. Fall, R. B. and Moore, F. B., Results of geologic studies and diamonddrilling in the northwest Carrizo area, Apache County, Arizona: (Official use only). July 1950.

109. Phoenix, D. A., Progress of ground-water studies, Nay 1950, Colorado Pla,teau Project: (Unclassified). June 1950.

110. Stephens, H. G., Diamond-drill exploration in Long Park and vicinity, Montrose County, Colorado: (Official use only). May 1950.

111. Bryner, Leonid, Preliminary appraisal of the results of diamond-drill exploration on Club Mesa, Montrose County, Colorado: (Official use only). June 1950.

112. Bell, Henry, III, and. Icke, H. M., Preliminary appraisal of diamonddrill exploration in the Spud Patch area, San Miguel County, Colorado: (Official use only). July 1950.

113. Bell, Henry, III, Results of diamond-drill exploration and plans for additional drilling in the Legin group area, San Miguel County, Colorado: (Official use only). August 1950.

114. Withington, C.F., Preliminary appraisal of diamond-drill exploration in the Upper group area, San Miguel County, Colorado: (Official use only). August 1950 .

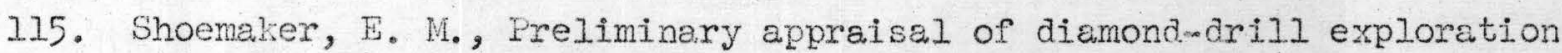
in the Jo Dandy area, Montrose County, Colorado: (Official use only). August 1950 .

116. Cathcart, J. B., Progress report on gamma-ray logging, land-pebble phos phate field, Florida: (Unclassified). July 1951.

117. Granger, H. C. and Bauer, H. L., Jr., Uranium occurrences on the Blue Jay claim, White Signal district, Crant County, New Mexico: (Pt. I, Unclassified; Pt. 2, Official use only). June 1951.

118. Granger, H. C., Preliminary investigation of radioactivity in the Black Hawk district, Grant County, New Mexico: (Unclassified). October 1950.

119. Granger, H. C. and Bauer, H. I., Jr., Reported occurrence of pitchblende, Black Range, Grant and Sierra Counties, New Mexico: (Unclassified). December 1950.

120. Gillerman, Blliot and Granger, H. C., The Hines and Langford uraniferous fluorspar prospects, Grant County, New Mexico: (Unclassified). January 1952. 
121. Bauer, H. L., Jr., Apache Trail uranium prospect, White Signal district, Grant County, New Mexico: (Pt。1, Unclassified; Pt。2, Official use only). June 1951.

122. Love, J. D., Uranium content of middle Pennsylvanian black shales penetrated in wells in southeastern Wyoming: (Unclassified). June 1951.

123. Davidson, D. F. and Wayland, T. E., Uranium and phosphate in the eastern part of the Bonny Lake mine, Polk County, Florida: (Official use only). May 1951.

124. Deul, Maurice, Summary report on public samples received 1949-50, Trace Elements Section Washington Laboratory, Geochemistry and Petrology Branch: (Unclassified). June 1951.

125. Johnson, D. H., A torbernite deposit near Stockton, Huntexdon County, New Jersey: (Unclassified). August 1950.

126. Wyant, D. G. and Beroni, E. P., Some preliminary estimates of potential reserves of western uraniferous lignites: (Secret). May 1950.

127. Klepper, M. R., Comstock claims near Basin, Jefferson County, Montana: (Unclassified). August 1950.

128. Granger, H. C. and King, R. U., Report of factual data obtained during examination of Copper King shaft, Black Hawk claim No. I, Larimer County, Colorado: (Unclassified). May 1950.

128A. Granger, H. C. and King, R. U., Uranium in the Copper King mine, Black Hawk No. I claim, Larimer County, Colorado: (Unclassified). April 1951.

129. McNeal, R. P., Radioactivity in the Yellowhouse field, Hockley County, Texas: (Unclassified). June 1950.

130. Cathcart, J. B., Reserves of uranium in the leached zone in the Gooch, Carlton Helms tract of the International Minerals and Chemical Corporation, Polk County, Florida: (Official use only). May 1950.

131. Hill, J.W., Radon-bearing gas in the Amarillo helium district, Texas: (Unclassified). August 1950.

132. Gott, G. B., The Leyden uranium prospect, Jefferson County, Colorado: (Unclassified). November 1950.

133. Beroni, E. P. and King, R. U., The Mike Doyle carnotite deposit, EI Paso County, Colorado: (Pt. 1, Unclassified; Pt. 2, Official use only). October 1950. (TIS).

134. Granger, H. C. and Bauer, H. L., Jr., A radiometric examination of the Tunnel Site No. I claim, Grant County, New Mexico: (Unclassified). December 1950. 
135. Faul, Henry and Sakakura, A. Y., Preliminary report on gamma-ray distribution in cylindrical cavities (drill holes): (Unclassified). June 1951.

136. Chace, F. M., An autunite deposit in the Rosamond Hills, Kern County, California: (Unclassified). August 1950.

137. Phoenix, D. A., Preliminary statement of the analyses of gtound water from the Morrison formation, southwestern Colorado and southeastern Utah: (Unclassified). August 1951.

138. Cathcart, J. B., Davidson, D. F。, Dutro, H. B., Ketner, K. B., Petersen, R. G., Tillman, C。 G., and Pratt, J. B., Reserves of phosphate rock and leached-zone material that will be mined by January 1956, land-pebble phosphate field, Florida: (Confidential). September 1951.

139. Bauer, H. L., Jr., Radioactive ilmenite, Virginia claim, Hillsboro mining district, Sierra County, New Mexico: (Unclassified). October 1950.

140. Roberts, W. A. and Gude, A. Jo, 3rd, Geology of the area adjacent to the Free Enterprise uranium-silver mine, Boulder district, Jefferson County, Montana: (Unclassified). March 1952. (B-988-G).

141. McNeal, R. P., Reconnaissance of the Howard-Glasscock oil field, Howard and Glasscock Counties, Texas: (Unclassified). August 1950.

142. Flanagan, F. J., Nelson, J.M., and Warr, J.J., Jr., Modification to Tracerlab automatic sample changer: (Unclassified). June 1950.

143. Stugard, Frederick, Jr., Nickel and cobalt prospect, Cobalt, Middlesex County, Connecticut: (Unclassified). November 1950.

144. Hewett, D. F., Uranium occurrence at the Hoerner-Ross pegmatite, Cady Mountains, San Bernardino County, California: (Unclassified). July 1950.

145. Kaiser, E. P., The Papsy's Hope autunite prospect, Marysvale district, Piute County, Utah: (Pt. 1, Unclassified; Pt。2, Official use only). July 1950. (TIS)。

146. Granger, H. C. and Bauer, H. L。, Jr., Results of diamond drilling, Merry Widow claim, White Signal, Grant County, New Mexico: (Unclassified). July 1950. (TIS; NSA).

147. Nelson, R. A., Sharp, W. N., and Stead, F. W., Airborne radioactivity survey of the Red Desert region, Sweetwater County, Wyoming: (Unclassified). July 1951. (TIS; NSA).

148. Brobst, D. A., Radioactivity at the Armentrout property, Erbacon, Webster County, West Virginia: (Unclassified). December 1950. 
149. Jaffe, E, B. and Sherwood, A. Mo, Physical and chemical comparison of modern and fossil tooth and bone material: (Unclassified). August 1951. (OF; TIS; NSA).

150. Bauer, H. L., Jr。, Klinger, F。 I., and Page, I. R., A uranium prospect, Black Hill, Sevier County, Utah: (Unclassified). October 1950 .

151. Bauer, H. I., Jro, and Klinger, F。 I., Monzonite in Dry Creek Canyon, Sevier Plateau, Sevier County, Utah: (Unclassified)。October 1950.

152. Page, I. R. and Redden, J.A., The carnotite prospects of the Craven Canyon area, Fall River County, South Dakota: (Pt. I, Unclassified; Pt. 2, Official use only). January 1952. $(\mathrm{C}=175)$.

153. Harrison, J. E. and Leonard, B. F。, Preliminary report on the Jo Reynolds area, Lawson-Dumont district, Clear Creek County, Colorado: (Pt. 1, Unclassified; Pt。2, Official use only). March 1952. $(\mathrm{C}-213)$.

154. Adams, J. Wo, Gude, A. J., 3rd, and Beroni, E. P., Uranium occurrences in the Golden Gate Canyon and Ralston Creek areas, Jefferson County, Colorado: (Pt. 1, Unclassified; Pt. 2, Official use only). January 1953. (C-320*; J-1).

155. Conant, I. C., Examination of drill cores of the Tennessee Coal, Iron, and Railroad Company, Jefferson County, Alabama: (Official use only). August 1950。

156. Fischer, R. P., Uranium and vanadium potential of the Colorado Plateau: (Secret). July 1950.

157. Cathcart, J. B., Extent, thickness, and grade of the leached zone in the land-pebble phosphate field, Polk and Hillsborough Counties, Florida, a progress report: (Secret)。 November 1950。

158. White, W. S. and Wright, J. C., Radioactivity of the Nonesuch shale, White Pine mine, Ontonagon County, Michigan: (Unclassified). October 1950.

159. James, H. I., Field investigation of airborne radioactivity anomalies in Marquette County, Michigan: (Unclassified). August 1950.

160. Bauer, H. L., Jr., Autunite at the Monarch No. 2, Moneymaker, and Wild Irishman claims, White Signal district, Grant County, New Mexico: (Unclassified)。 December 1950 .

161. Stead, F.W., Airborne radioactivity survey in the vicinity of Grants, McKinley, and Valencia Counties, New Mexico: (Unclassified). July 1951.

162. Staatz, M. H., Uranium prospect, Jan Group, Juab County, Utah: (Unclassified). September 1950. 
163. Cannon, H. I., Geobotanical reconnaissance for uranium in the Craven Canyon area, Fall River County, South Dakota: (Official use only). March 1953.

164. Stugard, Frederick, Jr., and Klinger, F。 L., Tiger Eye No. I uranium prospect, Sevier County, Utah: (Unclassified). December 1950.

165. Staatz, M. H. and Bauer, H. I., Jr., Preliminary examination of the uranium prospect at the Spider No. I claim, Honeycomb Hills, Juab County, Utah: (Unclassified). October 1950. (TIS).

166. Bales, W. F, and Erickson, R. L., Carnotite deposits in Craven and Coal Canyons, Fall River County, South Dakota: (Official use only). March 1952.

167. Staatz, M. H. and Bauer, H. L., Jr., A preliminary report on radioactive deposits, Thomas Range, Juab County, Utah: (Unclassified). September 1950. (TIS).

168. Ketner, Keith B., The aluminum phosphate zone of the hardrock phosphate belt, Florida.*

169. Wyant, D. G., Stugard, Frederick, Jr., and Kaiser, E. P., Uranium resources in the Marysvale region, Utah: (Official use only). September 1950.

170. Blackman, D. H, Geologic guides to carnotite deposits on the Colorado Plateau: (Unclassified). August 1950.

171. Rogers, A. S., Distribution of leached radioactive material in the Legin group area, San Miguel County, Colorado: (Unclassified). November 1950.

172. Cathcart, J. B., Estimated production, 1951-55, and uranium content of phosphate products, land-pebble field, Florida: (Secret). September 1950.

173. Phair, George and Onoda, Kiyoko, Verification of uraninite in fluorite breccias from the BIue Jay mine, Jamestown, Colorado: (Official use only). October 1950.

174. Rabbitt, J. C., Numerical summary of the analytical work of the Trace Elements Section, Geochemistry and Petrology Branch, for the fiscal year 1950: (Unclassified). October 1950.

175. Denson, N. M., Bachman, G. O., and Zeller, H. D., Summary of new information on uraniferous lignites in the Dakotas: (Confidential). January 1951.

176. Trace, R. D., Preliminary reserve statement 1, Reserve Block 1, Club Mesa, Montrose County, Colorado: (Official use only). September 1950 . 
177. Trace, R. D., Preliminary reserve statement 2, Reserve Blocks 3 and 4 , Club Mesa, Montrose County, Colorado: (Official use only). September 1950。

178. Trace, R。 Do, Preliminary reserve statement 3, Reserve Block 5 (east part), Club Mesa, Montrose County, Colorado: (Official use only). September 1950.

179. Trace, R. Do, Preliminary reserve statement 4, Reserve Block 5 (west part), Club Mesa, Montrose County, Colorado: (Official use only). September 1950。

180. Bush, A. Io, Preliminary reserve statement 5, Reserve Block A, Otero and Eloisa claims, Legin group, San Miguel County, Colorado:

(Official use only). September 1950.

181. Trace, R. D., Preliminary reserve statement 6, Reserve Blocks 1, 2, and 3, Veta Mad and Veta Glad claims, Georgetown group, San Miguel County, Colorado: (Official use only). September 1950 .

182. Trace, R. Do, Preliminary reserve statement 7, Reserve Blocks 5, 6, and 7, Georgeto claim, Georgetown group, San Miguel County, Colorado: (Official use only). September 1950.

183. Page, L. R., Interim report of geologic investigation, Lost Creek schroeckingerite deposits, Sweetwater County, Wyoming: (Unclassified). October 1950. (OF; TIS; NSA).

184. Trace, R. Do, Preliminary reserve statement 8, Reserve Block 2, Club Mesa, Montrose County, Colorado: (Official use only). October 1950。

185. Trace, R. D。, Preliminary reserve statement 9, Reserve Block A, Outlaw Mesa, Mesa County, Colorado: (Official use only). October 1950。

186. Brasher, G。 $K$. and Jobin, D。A.g Preliminary reserve statement 10 , Reserve Blocks $B$ and $C$, Mineral Channels Nos。 10 and 12 claims, Outlaw Mesa, Mesa County, Colorado: (Official use only)。 March 1951.

187. Newman, Wo L。, Preliminary reserve statement 11, Reserve Block A, Long Park vicinity, Montrose County, Colorado: (Official use only). March 1951.

188. Stephens, H。 Go, Preliminary reserve statement 12, Reserve Block B, Long Park Vicinity, Montrose County, Colorado: (Official use only). March 1951.

189. Brasher, G。 $K_{0}$ and Jobin, D. A., Preliminary reserve statement 13, Reserve Blocks $D_{2} E_{9} F_{9}$ and $G_{9}$ Outlaw Mesa, Mesa County, Colorado: (Official use only)。April 1951. 
190. Bell, Henry, III, Preliminary reserve statement 14, Reserve Blocks B and C, Legin Group area, San Miguel County, Colorado: (Official use only). May 1951.

191. Bell, Henry, III, Preliminary reserve statement 15, Reserve Block D, Legin Group area, San Miguel County, Colorado: (Official use only). May 1951.

192. Bell, Henry, III, and Cramer, M. A., Preliminary reserve statement 16, Reserve Blocks E, F, and G, Legin Group area, San Miguel County, Colorado: (Official use only). August 1951.

193. Stephens, H. G. and Cramer, M. A., Preliminary reserve statement 17, Reserve Blocks C and D, Long Park area, Montrose County, Colorado: (Official use only). October 1951.

194. McKelvey, V。E., Rare earths in western phosphate rocks: (Unclassified). October 1950 .

195. Denson, N. Mo, Uranium content of coal samples from the Mountain Home coal mine, Converse County, Wyoming: (Unclassified). October 1950 .

196. Fischer, R. P. and Davis, W. E., Status of plans for Geological Survey work in the Carrizo Mountains area, Arizona and New Mexico: (Official use only). November 1950.

197. Vhay, J. S., Reconnaissance radiometric examination of Spokane Molybdenum Mines property, Lincoln County, Washington: (Unclassified). October 1950.

198. Moore, F。 B. and Butler, C. R。, Pitchblende deposits at the Wood and Calhoun mines, Central City mining district, Gilpin County, Colorado: (Pt. I, Unclassified; Pt. 2, Official use only). October 1950. $(C-186)$.

199. Cannon, H. L., Preliminary report on geobotanical prospecting studies on the Colorado Plateau: (Unclassified). February 1951.

200. Bell, Henry, III, Preliminary appraisal of diamond-drill exploration in the Legin group area, San Miguel County, Colorado: (Official use only). February 1951.

201. Stephens, H. G. and Newman, W. L., Preliminary report on diamond-drill exploration and plans for additional drilling in Long Park and vicinity, Montrose County, Colorado: (official use only). June 1951.

202. Brasher, G. K. and Jobin, D. A., Results of diamond-drill exploration and plans for additional drilling on Outlaw Mesa, Mesa County, Colorado: (Official use only). April 1951. 
203. Fischer, R. P., Recommendations for a shift in emphasis of diamonddrilling on the Colorado Plateau: (Official use only). April 1951.

204. Bryner, Leonid and Withington, C. F., Interim report of diamond-drill exploration, Club Mesa, Montrose County, Colorado: (Official use only). May 1951.

205. Fischer, R. P., MacKallor, Jules, and Brown, C. N., Base maps of a part of the Thompsons district, Grand County, Utah: (Unclassified). February 1952. (OF)。

206. Sample, R。D。 and Albee, H. F., Claim map, Pine Mountain quadrangle, Mesa County, Colorado: (Official use only). August 1951.

207. Sample, R。D。 and Albee, H。F。, Claim map, Calamity Mesa quadrangle, Mesa County, Colorado: (Official use only). August 1951.

208. Sample, R。D。 and Albee, H. F., Claim map, Naturita NW quadrangle, Montrose and San Miguel Counties, Colorado: (Official use only). August 1951。

209. Craig, L。C。 and Freeman, V. L., Recommendations on geologic mapping and exploration of the Morrison formation in the northern Chuska Mountains, Arizona and New Mexico: (Official use only). January 1951.

210. Kaiser, E。 Po, Uraniferous quartzite, Red Bluff prospect, Gila County, Arizona: (Pt. 1, Unclassified; Pt. 2, Official use only). January 1951。(C-137)。

211. Wyant, $D_{0} G_{0}$, The East Slope No. 2 uranium prospect, Piute County, Utah: (Pt. 1, Unclassified; Pt. 2, Official use only). January 1951. $(\mathrm{C}-322) *$

212. Wyant, D. G。 and Stugard, Frederick, Jr。, Indian Creek uranium prospects, Beaver County, Utah: (Pt. 1, Unclassified; Pt. 2, Official use only). January 1951. (OF).

213. Beroni, E。P., McKeown, F。A., Stugard, Frederick, Jr., and Gott, G. B., Uranium deposits on the Bulloch group of claims, Kane County, Utah: (Unclassified). January 1951. (C-239).

214. Stugard, Frederick, Jr., Uranium resources in the Silver Reef (Harrisburg) district, Washington County, Utah: (Pt. I, Unclassified; Pt. 2, Official use only). January 1951. (OF).

215. Moore, F。 Bo, King, R。 U., and Hinrichs, E. N., Proposed exploration for uranium in the Front Range mineral belt, Colorado: (Official use only). January 1951.

216. Kaiser, E. Po, Radioactivity at the Jim Kane mine, Mohave County, Arizona: (Unclassified). January 1951. 
217. Kaiser, E。 P., Red Hills (Tate) uranium prospect, Mohave County, Arizona: (Unclassified). January 1951.

218. Singewald, Q。 D., Christman, R. A., and Brock, M。 R。, Preliminary report on 1952 field investigations in Wet Mountains, Colorado: (Official use only). January 1953.

219. Granger, H. C., An occurrence of radioactive pyromorphite, Golondrina claims, Graham County, Arizona: (Unclassified). January 1951.

220. Bauer, $\mathrm{H}_{0} \mathrm{I}_{0}, \mathrm{Jr}_{0}$, and Staatz, M. $\mathrm{H}_{0}$, Uranium occurrence on the Autunite No. 8 claim, east side of the Thomas Range, Juab County, Utah: (Pt. 1, Unclassified; Pt. 2, Official use only). July 1951.

221. Wyant, D. G., Proposed exploration, Papsy's Hope No. 2 uranium prospect, Piute County, Utah: (Official use only). January 1951.

222. Gott, G. B., Garo uranium deposits, Park County, Colorado: (Pt. I, Unclassified; Pt. 2, Official use only). June 1951.

223. Staatz, M. H., Stalin's Present uranium prospect, Pershing County, Nevada: (Pt. I, Unclassified; Pt. 2, Official use only). August 1951.

224. Singewald, Q. D。, Wilmarth, V.R., Pierson, C. T., and Vickers, R. C., Radioactive inclusions in Chalk Mountain rhyolite, Lake County, Colorado.*

225. Cannon, Ralph S., Jr., Radioactivity of alluvium downstrean from uranium deposits: (Official use only). April 1953.

226. Staatz, M. H. and Bauer, H. I., Jr., Uranium-bearing lignite beds at the Gamma property, Churchill County, Nevada: (Unclassified). June 1951.

227. Staatz, M. H. and Bauer, H. I., Jr., Virgin Valley opal district, Humboldt County, Nevada: (Pt. 1, Unclassified; Pt. 2, Officiol use only). May 1951. (C-142).

228. Staatz, M. H. and Bauer, H. L., Jr., Uranium in the East Walker River area, Lyon County, Nevada: (Pt. 1, Unclassified; Pt. 2, Official use only). August 1951. (B-988-C).

229. Roberts, W. A. and Gude, A. J., 3rd, Uranium-bearing deposits west of Clancey, Jefferson County, Montana: (Pt. 1, Unclassified; Pt. 2, Official use only). June 1951. (B-988-F; OF).

230. Wayland, T. E., Preliminary report on drilling in the eastern part of the Bonny Lake mine, Polk County, Florida: (Official use only). December 1950 . 
231. Petersen, $R$ 。 $G$, Uranium and phosphate in the western part of the Bonny Lake mine, Polk County, Florida: (Official use only). May 1951.

232. Davis, $W$. E。, Electrical resistivity investigations of carnotite de* posits in the Colorado Plateau: (Unclassified). April 1951. (TIS)。

233. Ketner, Ko B., Uranium and phosphate in the Hamilton tract, Polk County, Florida: (Officia.l use only). Apri1 1951.

234. Davidson, D。 Fo Cathcart, J。 $\mathrm{B}_{0}$, and Ketner, $K_{0}$ B。 Some results of channel sampling, Southeast Phosphate project, March 1949 July 1951: (Confidential). August 1951.

235. Wedow, Helmuth, Jro, White, $M_{0} G_{0}$, and Moxham, $R$ 。 $M_{0}$, Interim report on an appraisal of the uranium possibilities of Alaska: (Unclassio fied): March 1951。(OF).

236. McKelvey, V。E. Cathcart, J。B。, and Worthing, H。W., Preliminary note on the minor metal content of Florida phosphate rock: (Unclassified). January 1951. (TIS)。

237. Altschuler, $Z$ 。 $S_{0}$, Jaffe, E。 Bo, and Dwornik, Edward, The stratigraphy of the upper part of the Bone Valley formation and its relation to the leached zone: (Orficial use only). May 1951.

238. Altschuler, $Z$. So, The petrography and uranium content of phosphates from Morocco: (Official use only). November 1951.

239. Faul, Henry, Mangex, G。E。, and Sakakura, A。 Yo, Radon in the hellum bearing natural gas of the Texas Panhandle: (Unclassified)。 February 1951.

240. Narten, $\mathrm{P}, \mathrm{F}_{\circ}, \mathrm{Crawford} \mathrm{J}_{0} \mathrm{E}_{0}$, and Butler, A。 Po, Jro, Summary, re view of analytical data pertaining to the uranium content or radio activity of domestic shalles: (Confidential). January 1951.

241. Butler, A. Po, Jxo, and Bush, A。 Lo, Inspection of carnotite deposits near Mauch Chunk, Carbon County, Pennsylvania: (Official use only). February 1951.

242. Finch, W。 I., Preliminary report on diamond-drill exploration of parts of Blue and Moon Mesas, Mesa County, Colorado: (Official use only). February 1951.

243. Carr, Wo Jo, Cathcart, J.B., and Gray, C. Ho, Jro, Distribution of uranium in phosphate products of the land pebble phosphate field, Florida: a progress report: (Official use only). June 1952.

244. Wyant, D。G。 and Sheridan, D。 Mo Interim report, Lost Creek schroeckingerite deposit, Sweetwater County, Wyoming: (Official use only)。 May 1951. 
245. Swanson, R. Wo, Uranium content of the phosphate rock mined in Powe 11 County, Montana, and treated in Canada: (Official use only). April 1951.

246. Davidson, D. Fo, Uraniferous phosphate rock near Charleston, Charleston County, South Carolina: (Pt。1, Unclassified; Pt。2, Official use only). May 1951.

247. Smith, J.F., Jro, Preliminary report on geologic studies in the Capitol Reef area, Wayne County, Utah: (Unclassified). November 1951.

248. Mertie, J。B., Jr., Monazite in the southeastern states: (Unclassified)。 March 1951.

249. Gott, G。B., Smith, J.F。, Jro, and McKelvey, V. E, Plans for the Geological Survey's investigations of uranium in pre-Morrison formations in southern Utah, northern Arizona, and northwestern New Mexico: (Official use only). March 1951.

250. Rabbitt, J.C., Numerical summary of the analytical work of the Trace Elements Section, Geochemistry and Petrology Branch, for fiscal year 1951: (Unclassified). August 1951.

251. Weeks, A. D., Red and gray clay underlying ore-bearing sandstone of the Morrison formation in western Colorado: (Unclassified). Nay 1951. (OF; TIS; NSA).

252. Fletcher, $M_{0} H_{0}$ and Warner, $E, R, A$ fluorimeter for solutions: (Unclassified)。April 1951. (C-311*; OF; TIS; NSA).

253. Cathcart, J. B., Recommendations for prospecting for uranium in the land-pebble phosphate field, Florida: (Official use only). April 1951.

254. Page, L. R., Proposed beryllium program: (Official use only). June 1951.

255. Stewart, R. H., Radiometric reconnaissance examination in southeastern Pennsylvania and western New Jersey: (Official use only). Decenber 1951. (TIS).

256. Bryner, Leonid and Cramer, M. A., Preliminary reserve statement 18, Reserve Block 6, Club Mesa, Montrose County, Colorado: (Official. use only). October 1951.

257. Bel1, Henry, III, and Cramer, M. A。, Preliminary reserve statement 19 , supplemental report on Reserve Block F, Legin Group area, San Miguel County, Colorado: (Official use only). November 1951.

258. Brasher, G. Ko, Preliminary reserve statement 20, Reserve Blocks H, I, $\mathrm{J}, \mathrm{K}, \mathrm{I}, \mathrm{M}$, and $\mathrm{N}$, Outlaw Mesa, Mesa County, Colorado: (Official. use only). November 1951. 
259. Be11, Henry, III, and Cramer, M.A. Preliminary reserve statement 21, Reserve Blocks A and B, Spud Patch area, San Miguel County, Colorado: (Official use only). January 1952.

260. Bryner, Leonid and Cramer, M. A., Preliminary reserve statement 22, Reserve Block 7, Club Mesa, Montrose County, Colorado: (Official use only). Jamuary 1952.

261. Bryner, Leonid and Cramer, Mo A. Preliminary reserve statement 23, Reserve Block 8, Club Mesa, Montrose County, Colorado: (Official use ondy)。 March 1952.

262. Jobin, D。A. Preliminary reserve statement 24, Reserve Block A, Dolores Bench, Montrose County, Colorado: (Official use only). November 1952 .

263. Jobin, D. A. Preliminary reserve statement 25, Reserve Block B, Dolores Bench, Montrose County, Colorado: (Official use only). November 1952 .

264. Jobin, D.A. Preliminary reserve statement 26, Reserve Block C, Dolores Bench, Montrose County, Colorado: (Official use only). November 1952 .

265. Jobin, D.A., Preliminary reserve statement 27, Reserve Block A, Atkinson Mesa, Montrose County, Colorado: (Official use only). February 1953.

266. Sample, R. D。 and Albee, F. F, Claim map, Atkinson Creek quadrangle, Montrose County, Colorado: (Official use only). August 1951.

267. Sample, R. Do and Albee, H. Fo, Claim map, Davis Mesa quadrangle, Montrose County, Colorado: (Official use only). August 1951.

268. Sample, R. D. and Albee, H。 F, Claim map, Bull Canyon quadrangle, Montrose and San Miguel Counties, Colorado: (Official use only). August 1951 .

268A, Sample, R。D, Albee, $H_{,}$., , and Stephens, $H_{0} G_{0}$, Claim map, BuII Camyon quadrangle, Montrose County, Colorado: (Official use on1y). Apri1 1953.

269. Finch, W. I. Preliminary report on diamond drill exploration of part of Blue Mesa, Mesa County, Colorado: (Official use only). August 1951 .

270. Phoenix, D. A. Preliminary report on correlation between the gammaray logs and permeability of the ore bearing sandstone in the Morrison formation, Calamity Mesa, Mesa County, Colorado: (Unclassified). October 1951.

271. McKay, E。 Jo, Large scale geologic guides to carnotite deposits in the Uravan and Gateway districts, Montroseiand Mesa Counties, Colorado: (Unclassified). September 1951 . 
272. Cannon, H. I., Geobotanical reconnaissance near Grants, New Mexico: (Unclassified)。 November 1951. (C-264)。

273. Cannon, H. Io, Preliminary report on geobotanical exploration in the Yellow Cat district, Grand County, Utah: (Unclassified). October 1951.

274. Brew, David A。, Preliminary report on exploration in the Atkinson Mesa area, Montrose County, Colorado: (Confidential). June 1953.

275. Bell, Henry, III, Preliminary report on diamond-drill exploration of the Legin group area, San Miguel County, Colorado: (Official use only). October 1951 .

276. Fischer, R. P., Hilpert, I. So, Schumacher, J。 I., Cater, F。W., Strobe11, J. D., Jr., Craig, L. C., Phoenix, D. A。, and Trace, R. D. , Summary of investigations through 1950 of the carnotitebearing sandstones of the Colorado Plateau: (Secret). October 1951.

277. Ca.thcart, J. Bo, Leached zone material in overburden dumps, landpebble phosphate district, Florida: a preliminary report:

(Official use only). December 1951.

278. Read, C. B。, Recent discoveries of radioactive carbonaceous shale, Sandoval County, New Mexico: (Official use only). January 1952.

279. Davidson, D. F., Results of drilling on the Lowe property, Citrus County, Florida: (Official use only). January 1952.

280. Conant, I. C., Summary of the results of investigations of the Chattanooga shale through June 1950: (Confidential). August 1951.

281. Aberdeen, E. J., White, W. F., Sherwood, A. M०, Bruce, F. I., and Ferguson, D. E., Interim report on the location of nonsaline uraniferous waters: (Confidential-Restricted Data). November 1952.

282. Love, J. D., Preliminary report on uranium-bearing Pliocene (?) rocks in the Split Rock area, central Wyoming: (Official use only). July 1952.

283. Overstreet, W. C. and Theobald, P. K., Jr, , Progress report on investigations of southeastern monazite placers: (Official use only). January 1952.

284. Sheridan, D. M., Plans for geologic exploration of the Lost Creek schroeckingerite deposit, Sweetwater County, Wyoming, during fiscal year 1952: (Official use only). August 1951.

285. Dellwig, I. F. and Gott, G. B., Radioactive deposits on the Haputa Ranch, Custer County, Colorado: (Pt. 1, Unclassified; Pt. 2, Official use only). November 1951. 
286. Sharp, W. N. and Cavender, W. S., Preliminary report on the Mineral Hill monazite deposits, Lemhi County, Idaho: (Official use only). April 1953.

287. Dellwig, L. Fo, Preliminary summary report on the Wet Mountains thorium area, Custer and Fremont Counties, Colorado: (Official use only). December 1951.

288. Sheridan, D。 Mo, Collier, J。T., and Sears, R. S., Results of exploration at Lost Creek schroechingerite deposit, Sweetwater County, Wyoming, July 1951-February 1952-man interim report: (Confidential). July 1952.

289.

290. Gott, G. Bo and Erickson, R. L., A preliminary summary report of a reconnaissance of sandstone-type copper-uranium deposits in parts of New Mexico, Colorado, Utah, Idaho, and Wyoming: (Official use only). December 1951.

291. Harrison, J。 E。, The uranium occurrences in the Martha E prospect, Lawson-Dumont district, Clear Creek County, Colorado: (Official use only). April 1952。

292. Gude, A。 J., 3rd, and McKeown, F。A., Results of exploration at the old Leyden coal mine, Jefferson County, Colorado: (Pt. 1, Un. classified; Pt. 2, Official use only). December 1952。 (OF).

293. Beroni, E. Po and Whitebread, D. Wo, Reconnaissance for uranium in Rawhide Buttes area, Niobrara and Goshen Counties, Wyoming.*

294. Bell, Henry, III, Interim report on exploration in the Spud Patch area, San Miguel County, Colorado: (Official use only). January 1952.

295. Brasher, G. Ko, Preliminary report on diamondwdrill exploration on Outlaw Mesa, Mesa County, Colorado: (Confidential). January 1952.

296. Bryner, Leonid and Douglas, $R_{0} F_{0}$, Interim report on exploration on Club Mesa, Montrose County, Colorado: (Confidential). March 1952.

297. Stephens, $H_{0} G_{\%}$ and Ekren, E. Bo, Preliminary report on diamond-drill exploration and plans for additional drilling in Long Park and vicinity, Montrose County, Colorado: (Confidential). January 1952.

298. Bush, A。 I and Bryner, Leonid, Freliminary report on the uranium and vanadium resources of the Entrada sandstone, western San Juan Mountains, Colorado: (Confidential). January 1953. 
299. Stewart, J. H., Interim report on exploration of the Moon Mesa and Horse Mesa areas, Mesa and Montrose Counties, Colorado: (Official use only). March 1952.

300. Strobell, J. D., Jr., Preliminary appraisal of the carnotite resources of the Carrizo Mountains area, San Juan County, New Mexico, and Apache County, Arizona: (Confidential). May 1952.

301. Luedke, R. G. and Shoemaker, E. M., Tectonic map of the Colorado Plateau (including text "Structural setting of the Colorado Plateau," by E. M. Shoemaker): (Unclassified). 1952. (OF; NSA).

302. Vogel, J. D., Interim report on exploration of the Jo Dandy area, Montrose County, Colorado: (Confidential). March 1953.

303. Hilpert, I. S., Preliminary report on exploration in the Spud Patch area, San Miguel County, Colorado: (Official use only). July 1952.

304. Granger, H. C., Preliminary summary of reconnaissance for uranium in Arizona: (Official use only). August 1951.

305. Koozy, Gerta, Further uranium determinations on sea water samples (translated by J. B. Lyons): (Unclassified). September 1951.

306. Sakakura, A. Y., Theory of gamma-ray logging: preliminary calculations: (Unclassified). December 1951. (TIS; NSA).

307. Wilmarth, V. R., Preliminary report on the thucholite deposits near Placerville, San Miguel County, Colorado: (Official use only). September 1951.

308. McKeown, F. A. and Gude, A. J., 3rd., Preliminary report on the carnotite deposits of the old Leyden coal mine, Jefferson County, Colorado: (Official use only). September 1951.

309. Bachman, G. O. and Read, C. B., Results of recent reconnaissance investigations of uranium in coal, black shale, and related deposits, in Sandoval and Rio Arriba Counties, New Mexico: (Official use only). September 1951.

310. Burbank, W. S. and Pierson, C. T., Preliminary results of radiometric reconnaissance of parts of the northwestern San Juan Mountains, Gunnison, Ouray, San Juan, San Miguel, and Dolores Counties, Colorado: (Official use only). March 1952. (C-236).

311. BelI, K. G., Progress in development of gamma-ray logging instruments and techniques: (Unclassified). October 1951.

312. Suess, H. E., An outline of a research program on the cosmic abundance. of nuclear species: (Unclassified). September 1951.

313. Wilmarth, V. R., Preliminary report on carnotite at the Yellow Canary claims, Daggett County, Utah: (Official use only) September 1951. 
314. Stead, F.W., Progress in airborne radioactivity surveying: (Official use only). April 1952.

315. Ketner, K. B., Correlation between uranium and $\mathrm{P}_{2} \mathrm{O}_{5}$ in a coarse pebble phosphate deposit, Florida: (Official use only). February 1952.

316. Rowe, J. J., Noninterference of arsenate ion in the volumetric deter. mination of uranium using the Jones reductor: (Unclassified). October 1951. (B-1006\% NSA).

317. Stieff, L. R, and Stern, T, W., The identification and leaduranium ratio ages of massive uraninite from the Shinarump conglomerate, Utah: (Unclassified). October 1951. (J-98).

318. Witkind, I. J., McKay, E. J., Johnson, D. H., Finnell, T. I. , Claus, R. J., and Johnson, D. L., Preliminary report on geologic studies in the Monument Valley area, Arizona: (Official use only). October 1951.

319. Tolbert, G. E. and Nelson, A. E., Preliminary summary of reconnaissance for uranium in the Alaska Railroad-Iliamna region during 1951: (Unclassified). December 1951. (Cw196).

320. Nelson, A. E. and Tolbert, G. E., Preliminary summary of reconnaissance for uranium in the Gulf of Alaska region during 1951: (Unclassified). December 1951. (Cw196).

321. Houston, J. R., Preliminary summary of reconnaissance for uranium in southeastern Alaska during 1951: (Unclassified). December 1951. $(\mathrm{C}-196)$.

322. White, M. G. and West, W. S., Preliminary summary of reconnaissance for uranium on the Seward Peninsula, Alaska during 1951: (Unclassified). January 1952. (C-196).

323. Wedow, Helmuth, Jr., Adaptation of portable survey meters for air. borne reconnaissance with light planes in Alaska: (Unclassified). October 1951. (TIS).

324. Fischer, R。 P., Low-grade carnotite material in the Morrison formation on the Colorado Plateau: (Confidential). January 1952.

325. Benson, W. E., Trites, A. F., Jr., Beroni, E. P., and Feeger, J. A., Preliminary report on the White Canyon area, San Juan County, Utah: (Pt. 1, Unclassified; Pt. 2, Official use only). February 1952. $(\mathrm{C}-217)$.

326. Moxham, R. M., Radioactive minerals in the Yakataga Beach placers, southern Alaska: (Unclassified). January 1952. (C-184).

327. White, $M_{0} G_{\circ}$, Radioactivity and mineralogy of placer concentrates from the Wiseman and Chandalar districts, Upper Yukon region, northeastern Alaska: (Unclassified). January 1952. (C-195). 
328. Wedow, Helmuth, Jr., Uraniferous phosphate rock in the Brooks Range, northern Alaska.*

329. White, M. G。 and Nelson, $A_{0} E_{0}$, Radiometric reconnaissance of the Fortymile Highway from the Alaska Highway to Chicken, Alaska.*

330. Moxham, R. M and West, W. S., A radiometric traverse along the Alaska Railroad: (Official use only). February 1953.

331. Wyant, D. Go, Summary of investigations in Venezuela from June to November 1951: (Confidential). November 1951.

332. Stager, H. Ko, Plans for the Geological Survey's development drilling program, Colorado Plateau: (Official use only). January 1952.

333. Brown, Andrew, Notes on eastern oil shale drilling: (Official use only). January 1952.

334. Cathcart, J. B., A drilling program for land in areas near Brewster and Mulberry, land-pebble phosphate district, Florida: (Official use only). January 1952.

335. Meyrowitz, Robert, A new series of immersion liquids: (Unclassified). March 1952. (C-250; J-69; NSA).

336. Duncan, $D_{0} C_{0}$, Preliminary report on a uranium-bearing rhyolitic tuff deposit near Coaldale, Esmeralda County, Nevada: (Unclassified). February 1952. (C-291; TIS).

337. Davidson, D. Fo, Relation of the "topography" of the Hawthorn formation to size of phosphate particles in the deposits, and to topography, in the northern part of the land-pebble phosphate field, Florida: (Unclassified). May 1952. (TIS).

338. Duncan, D. Co, Preliminary statement of results of black-shale inves tigations in the western states: (Unclassified). February 1952.

339. Bates, R. G. and Wedow, Helmuth, Jr., Preliminary summary review of thorium-bearing mineral occurrences in Alaska: (Unclassified). March 1952. $(\mathrm{C}-202)$.

340. Vine, J. D. and Moore, G. W., Occurrence of uranium-bearing coal, carbonaceous shale, and carbonaceous limestone in the Fall Creek area, Bonneville County, Idaho: (Pt. 1, Unclassified; Pt. 2, Official use only). March 1952. (C-212). 
341. Denson, $N_{0} M_{*}$, with description of deposits by Bachman, G. 0., Gill, $J_{\circ} R_{0}$, Hail, W. J., Jr., Love, J. D., Masursky, Harold, Denson, $N_{0} M_{*}$, Moore, $G_{0} W_{0}$, Pipiringos, $G, \mathbb{N}_{*}$, Vine, $J_{0} D_{0}$, and Zeller,

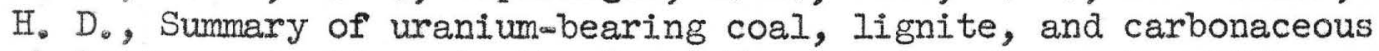
shale investigations in the Rocky Mountain region during 1951: (Confidential). May 1952.

342. Zeller, Howard D., Results of core drilling for uranium-bearing liginites in the Bar H area, Slim Buttes, Harding County, South Dakota: (Official use only). June 1953.

343. Coats, $R_{0} R_{0}$, Preliminary report of reconnaissance for uraniferous granitic rocks in Montana, Idaho, Oregon, Washington, and California: (Official use only). April 1952.

344. Meuschke, J。 I*, Aeromagnetic profiles of the Monument Valleymarrizo Mountains area, Arizona.*

345. Sample, R. D. and Albee, H. F., Claim map, Paradox quadrangle, Montrose County, Colorado: (Official use only). March 1952.

346. Sample, R. D。 and Albee, H. F., Claim map, Gypsum Gap quadrangle, San Miguel County, Colorado: (Official use only). March 1952.

347. Sample, R。 D. and Albee, H. F., Claim map, Uravan quadrangle, Montrose County, Colorado: (Official use only). March 1952.

348. Sample, R. D. and Albee, H. F., Claim map, Juanita Arch quadrangle, Mesa County, Colorado: (Official use only). January 1953.

349. Sample, R。 D. and Albee, H. F., Claim map, Roc Creek quadrangle, Montrose County, Colorado: (Official use only). December 1952.

350. Sample, $R . D_{0}$, Albee, $H_{\text {. }}$ F, and Stephens, H. G., Claim map, Red Canyon quadrangle, Montrose County, Colorado: (Official use only). January 1953.

351. Sample, R。 D., Albee, H. F., and Stephens, H. G., Claim map, Hamm Canyon quadrangle, San Miguel County, Colorado: (Official use only). January 1953.

352. Alvord, D. C., Interim report on exploration in the Yellow Cat area, Grand County, Utah: (Official use only). September 1952.

353. Trimble, D, E., Unclaimed mineralized area in the Shinarump conglomerate, northwest of Oljeto Trading Post, Utah: (Official use only). June 1952.

354. Faul, Fenry and Hunt, C. B., Radon in the Dillon tunnel in Miner's Basin north La Sal Mountains, Grand County, Utah: (Official use only). September 1952 . 
355. West, W. S., Reconnaissance for a uranothorianite-bearing lode in the vicinity of the headwaters of the Peace River, Candle quadrangle, Seward Peninsula, Alaska: (Unclassified). June 1952. (C-250; OF).

356. Houston, J.R., Interim report on the radioactive carbonate-hematite veins near Salmon Bay, Prince of Wales Island, southeastern Alaska: (Official use only). June 1952.

357. Wedow, Helmuth, Jr., Summary of reconnaissance for radioactive deposits in Alaska by the Geological Survey duxing the period 19451953 and an appraisal of Alaska uranium possibilities.*

358. Bates, R. G, (compiled by), Preliminary index to Geological Survey Trace Elements reports on Alaska for the period January 1945December 1952: (Official use only). February 1953.

359. Meuschke, J. L., Aeromagnetic survey of Uravan mineral belt.*

360. Moxham, R. M. Airborne radioactivity surveys in the Mojave Desert region, Kern, Riverside, and San Bernardino Counties, California: (Unclassified). July 1952. (TIS; NSA).

361. Nelson, R. A., Airborne radioactivity survey in Liberia, West Africa: (Official use only). September 1952.

362. Davidson, D. F., Grain size distribution in the surface sands, and the economic phosphate deposits of the land-pebble phosphate district, Florida: (Unclassified). August 1952. (TIS: NSA).

363. Cathcart, J. B., Recommendations for geological drilling, land-pebble phosphate district, Florida: (Official use only). May 1952.

364. Hackman, R. J., Photogeologic map, Aneth-2 quadrangle, San Juan County, Utah: (Unclassified). May 1952. (OF).

365. Hackman, R. J., Photogeologic map, Aneth-3 quadrangle, San Juan County, Utah: (Unclassified). May 1952. (OF).

366. Hackman, R. J., Photogeologic map, Aneth-4 quadrangle, San Juan County, Utah: (Unclassified). 1952. (OF).

367. Hackman, R。 J., Photogeologic map, Aneth-7 quadrangle, San Juan County, Utah: (Unclassified). May 1952. (OF).

368. Hackman, R. J., Photogeologic map, Aneth-8 quadrangle, San Juan County, Utah: (Unclassified). May 1952. (OF). 
369. Hackman, Ro J., Photogeologic map, Bluff-l quadrangle, San Juan County, Utah: (Unclassified). April 1952. (OF).

370. Hackman, $R_{0} J_{0}$, Photogeologic map, Bluff-8 quadrangle, San Juan County, Utah: (Unclassified), May 1952。(OF).

371. Ray, R。G., Photogeologic map, Bluff-13 quadrangle, San Juan County, Utah: (Unclassified). May 1952。(OF).

372. Tolbert, G. E。, Photogeologic map, Carlisle-1 quadrangle, San Juan County, Utah: (Unclassified)。 March 1952。(OF).

373. Tolbert, G. E., Photogeologic map, Carlisle-8 quadrangle, San Juan County, Utah: (Unclassified). March 1952. (OF).

374. Tolbert, G. E。, Photogeologic map, Carlislew9 quadrangle, San Juan County, Utah: (Unclassified). May 1952. (OF).

375. Tolbert, G。 E., Photogeologic map, Carlisle-16 quadrangle, San Juan County, Utah: (Unclassified). May 1952. (OF).

376. Hackman, R. Jo, Photogeologic map, Elk Ridge 13 quadrangle, San Juan County, Utah: (Unclassified). May 1952。 (OF)。

377. Hackman, R. J., Photogeologic map, Elk Ridge 16 quadrangle, San Juan County, Utah: (Unclassified). April 1952. (OF).

378. Tolbert, G. E。, Photogeologic map, Mt. Peale-5 quadrangle, San Juan County, Utah: (Unclassified). April 1952. (OF).

379. Tolbert, G. E。, Photogeologic map, Mt. Pealo-6 quadrangle, San Juan County, Utah: (Unclassified). April 1952. (OF).

379A. Tolbert, G. E. and Hackman, R. Jo, Photogeologic map, Mt. Peale -6 quadrangle, San Juan County, Utah: (Unclassified)。 March 1953. (OF)

380. Tolbert, G。 E., Photogeologic map, Mt. Peale-ll quadrangle, San Juan County, Utah: (Unclassified). April 1952. (OF).

380A. Hackman, R. J. and Tolbert, G。 E., Photogeologic map, Mt. Peale-1l. quadrangle, San Juan County, Utah: (Unclassified). December 1952. (OF)。

381. Tolbert, G. E。, Photogeologic map, Mt. Peale-12 quadrangle, San Juan County, Utah: (Unclassified). May 1952. (OF).

382. Tolbert, G。E。, Photogeologic map, Mt. Peale-14 quadrangle, San Juan County, Utah: (Unclassified). May 1952. (OF).

383. Ray, R. Go, Photogeologic map, Stinking Spring Creek II $_{\text {quadrangle, }}$ Emery County, Utah: (Unclassified). May 1952. (OF). 
384. Fischer, W. A., Photogeologic map, Stinking Spring Creek-12 quadrangle, Emery County, Utah: (Unclassified). May 1952. (OF).

385. Hackman, R. J., Photogeologic nap, Verdure $=9$ quadrangle, Coloradow Utah: (Unclassified). April 1952. (OF).

386. Hackman, R. Jo, Photogeologic map, Verdure -10 quadrangle, San Juan County, Utah: (Unclassified). April 1952. (OF).

387. Hackman, R. J., Photogeologic map, Verdure 11 quadrangle, San Juan County, Utah: (Unclassified). April 1952. (OF).

388. Hackman, R. J., Photogeologic map, Verdure-12 quadrangle, San Juan County, Utah: (Unclassified). March 1952. (OF).

389. Hackman, R. J., Photogeologic map, Verdure-13 quadrangle, San Juan County, Utah: (Unclassified), 1952. (OF).

390. Hackman, R. J., Photogeologic map, Vexdure -14 quadrangle, San Juan County, Utah: (Unclassified), April 1952. (OF).

391. Hackman, $R, J$, Photogeologic map, Verdure-15 quadrangle, San Juan County, Utah: (Unclassified). May 1952. (OF).

392. Hackman, R. J., Photogeologic map, Vexdure-16 quadrangle, Coloradow Utah: (Unclassified). May 1952. (OF).

393. Hackman, R. Jo, Photogeologic map, Aneth-5 quadrangie, San Juan County, Utah: (Unclassified). July 1952. (OF).

394. Bates, C. E., Photogeologic map, Stinking Spring Creek-14 quadrangle, Emery County, Utah: (Unclassified). July 1952. (OF).

395. Hackman, R. J., Photogeologic map, Verdure -7 quadrangle, San Juan County, Utah: (Unclassified). July 1952. (OF).

396. Hackman, R. J., Photogeologic map, Elk Ridge-12 quadrangle, San Juan County, Utah: (Unclassified). July 1952. (OF).

397. Bates, C. E。, Photogeologic map, Stinking Spring Creek-13 quadrangle, Emery County, Utah: (Unclassified). July 1952, (OF).

398. Tolbert, G. E., Photogeologic map, Mt. Peale-13 quadrangle, San Juan County, Utah: (Unclassified). July 1952. (OF).

399. Hackman, R. Jo, Photogeologic map, Vexdure - I quadrangle, ColoradoUtah: (Unclassified). July 1952. (OF).

400. Hackman, R. J., Photogeologic map, Aneth-6 quadrangle, San Juan County, Utah: (Unclassified). July 1952. (OF).

401. Ray, R. G., Photogeologic map, Bluff 14 quadrangle, Navajo Indian Reservation, San Juan County, Utah: (Unclassified). July 1952. (OE). 
402. Ray, R. G., Photogeologic map, Setsiltso Springs-3 quadrangle, Navajo Indian Reservation, Apache County, Arizona: (Unclassified). July 1952. (OF).

403. Hackman, R. J., Photogeologic map, Verdure -8 quadrangle, Coloradow Utah: (Unclassified), July 1952。(OF).

404. Ray, $R_{*} G_{*}$, Photogeologic map, Setsiltso Springs -4 quadrangle, Navajo Indian Reservation, Apache County, Arizona: (Unclassifiecl). August 1952. (OF).

405. Hackman, R。 J., Photogeologic map, Verdure-6 quadrangle, San Juan County, Utah: (Unclassified). July 1952. (OF)。

406. Hackman, $R_{0} J_{0}$, Photogeologic map, Verdure-2 quadrangle, San Juan County, Utah: (Unclassified). July 1952。(OF).

407. Hackman, R.J., Photogeologic map, Elk Ridge-8 quadrangle, San Juan County, Utah: (Unclassified.). August 1952. (OF).

408. Hackman, R. J., Photogeologic map, Verdure 5 quadrangle, San Juan County, Utah: (Unclassified). August 1952. (OF).

409. Fischer, W. A., Photogeologic map, Clay Hills-13 quadrangle, Navajo Indian Reservation, San Juan County, Utah: (Unclassified). JuIy 1952. (OF).

410. Hackman, R。 J., Photogeologic map, Elk Ridge-I quadrangle, San Juan County, Utah: (Unclassified). August 1952. (OF).

411. Eckstein, $W_{0} H_{0}$, Photogeologic map, Agathla Peak-2 quadrangle, Navajo Indian Reservation, Navajo County, Arizona: (Unclassified). June 1952. (OF).

412. Hackman, R. J., Photogeologic map, Agathla Peakw quadrangle, INavajo Indian Reservation, Navajo County, Arizona: (Unclassified). August 1952. (OF).

413. Fischer, W. Ao, Photogeologic map, Clay Hills-12 quadrangle, Piute Indian Reservation, San Juan County, Utah: (Unclassified). July 1952。(OF)。

414. Eckstein, W.H. Photogeologic map, Clay Hills-15 quadrangle, Navajo Indian Reservation, San Juan County, Utah: (Unclassified)。 August 1952. (OF).

415. Strobell, J。 D., Jr., Dinne Mesa NW, preliminary geologic map of part of the Carrizo Mountains area, northeastern Arizona: (Unclassified). June 1952. (ONA t)*

416. Strobell, J. D., Jr., Dinne Mesa SW, preliminary geologic map of pari of the Carrizo Mountains area, northeastern Arizona: (Unclassified). June 1952. (OMH) * 
417. Strobe11, J. Do, Jro, Los Gigantes NW, preliminary geologic map of part of the Carrizo Mountains area, northeastern Arizona: (Unclassified). June 1952。( $\left.\mathrm{OM} \mathrm{k}^{*}\right)$.

418. Strobe11, J。 D。, Jro, Los Gigantes NE, preliminary geologic map of part of the Carrizo Mountains area, northeastern Arizona: (Un. classified)。 June 1952. (OM-k*)。

419. Strobe11, J。 $D_{0}, J r_{0}$, Red Rock Valley NW, preliminary geologic map of part of the Carrizo Mountains, area, northeastern Arizona: (Unclassified)。 June 1952. (OM-K*)。

420. Strobell, J。 D., Jr。, Red Rock Valley NE, preliminary geologic map of part of the Carrizo Mountains area, northeastern Arizona and northwestern New Mexico: (Unclassified)。 June 1952. (OM-k*).

421. Strobel1, J。 Do, Jro, Red Rock Valley SE, preliminary geologic map of part of the Carrizo Mountains area, northeastern Arizona and northwestern New Mexico: (Unclassified)。 June 1952. (OMmk*).

422. Strobell, J。 D., Jro, Red Rock Valley SW, preliminary geologic map of part of the Carrizo Mountains area, northeastern Arizona: (Unclassified)。 August 1952. (NSA; OM-k*).

423. Strobe11, J. Do, Jr., Dinne Mesa NE, preliminary geologic map of part of the Carrizo Mountains area, northeastern Arizona: (Unclassified). August 1952. (NSA; OM- $\mathrm{K}^{*}$ )。

424. Strobe11, J. Do, Jro, Dinne Mesa SE, preliminary geologic map of part of the Carrizo Mountains area, northeastern Arizona: (Unclassified). August 1952. (NSA; OM- $\mathrm{K}^{*}$ ).

425. Strobeli, J. Do, Jro, Pastora Peak NE, preliminary geologic map of part of the Carrizo Mountains area, northeastern Arizona and northwestern New Mexico: (Unclassified). August 1952. (NSA; OMols*).

426. Strobell, J. Do, Jrog Pastora Peak NW, preliminary geologic map of part of the Carrizo Mountains area, northeastern Arizona: (Unclassified)。 August 1952. (NSA; OM=k*).

427. Strobell, J。 Do, Jr。, Pastora Peak SE, preliminary geologic map of part of the Carrizo Mountains area, northeastern Arizona and northwestern New Mexico: (Unclassified). August 1952. (NSA; OMmk*).

428. Strobel1, J. Do, Jr., Pastora Peak SW, preliminary geologic map of part of the Carrizo Mountains area, northeastern Arizona: (Unclassified). August 1952. (NSA; OMmk*)。

429. Strobe11, J. D., Jr., Los Gigantes SE, preliminary geologic map of part of the Carrizo Mountains area, northeastern Arizona: (Unclassified). August 1952. (NSA; OM=k*). 
430. Strobell, J. Do, Jr., Los Gigantes SW, preliminary geologic map of part of the Carrizo Mountains area, northeastern Arizona: (Unclassified). August 1952. (NSA; OM-k*).

431. Weeks, Alice $D_{*}$, Summary report on mineralogic studies of the Colorado Plateau through April 30, 1952: (Official use only). June 1952.

432. Mapel, $W_{0}$ Jo and Hail, W。 J., Summary of preliminary results of field studies in 1952 in the Goose Creek district, Cassia County, Idaho, Boxelder County, Utah, and Elko County, Nevada: (Official use only). January 1953.

433. Hackman, R. Jo, Photogeologic map, Verdure-3 quadrangle, San Juan County, Utah: (Unclassified). August 1952. (OF).

434. Schnabel, R. W. and Vickers, R. C., Reconnaissance of the Clinton formation in New York, Pennsylvania, Maryland, and New Jersey: (Unclassified). January 1953. (TIS; NSA).

435. Bachman, G. O. and Read, C. B., Uranium-bearing copper deposits near Guadalupita, Mora County, New Mexico: (Official use only). September 1952.

436. Cathcart, J. B., Carx, W. J., Petersen, R. G., and Gray, C. H., Jr., Distribution of the leached zone of the Bone Valley formation, land-pebble phosphate field, Florida: (Confidential). September 1952.

437. Weeks, A. Do, Summary report on Colorado Plateau clay studies through April 30, 1952: (Official use only). July 1952.

438. Hackman, R. J., Photogeologic map, Verdure 4 quadrangle, San Juan County, Utah: (Unclassified). August 1952. (OF).

439. Ray, R. Go, Photogeologic map, Setsiltso Springs-5 quadrangle, Navajo Indian Reservation, Apache County, Arizona: (Unclassified). August 1952. (OF).

440. Ray, R. G. Photogeologic map, Agathla Peak-8 quadrangle, Navajo Indian Reservation, Navajo County, Arizona: (Unclassified). August 1952. (OF).

441. Ray, R. G., Photogeologic map, Agathla Peak-1 quadrangle, Navajo Indian Reservation, Navajo County, Arizona: (Unclassified). September 1952. (OF).

442. Fischer, W. A., Photogeologic map, Clay Hills-14 quadrangle, Navajo Indian Reservation, San Juan County, Utah: (Unclassified). September 1952. (OF).

443. Bachman, $G_{0} O_{0}$ and Read, $C, B_{0}$, Trace Elements reconnaissance inves. tigations in New Mexico and adjoining states in 1951: (Official use only). October 1952. 
444. Duncan, D. Co, Results of reconnaissance for uranium in nonmarine carbonaceous rocks in parts of California, Idaho, Nevada, Oregon, Utah, and Washington during 1951 and 1952: (Orficial use only). March 1953. (TIS) *

445. Tourtelot, H. A., Reconnaissance for uraniferous rocks in northeastern Wind River Basin, Wyoming: (Unclassified). August 1952. (TIS: NSA).

446. Hail, W. J., Jr., and Gill, J. R., Results of reconnaissance for uraniferous coal, lignite, and carbonaceous shale in western Montana: (Unclassified). September 1952. (C -251 ; NSA).

447. Hackman, R. J., Photogeologic map, Mt. Peale-15 quadrangle, San Juan County, Utah: (Unclassified). October 1952. (OF).

448. Hackman, $R_{0}$ Jo, Photogeologic map, Mt。 Peale-16 quadrangle, UtahColorado: (Unclassified). September 1952. (OF).

449. Bates, C. E. and Eckstein, W. H., Photogeologic map, Clay Hills-16 quadrangle, Navajo Indian Reservation, San Juan County, Utah: (Unclassified). September 1952. (OF)。

450. Hackman, R。 J., Photogeologic map, Mt, Pealem9 quadrangle, UtahColorado: (Unclassified). September 1952。(OF).

451. Hackman, R。 J., Photogeologic map, Mt. Peale-10 quadrangle, San Juan County, Utah: (Unclassified). October 1952. (OF).

452. Hackman, R. J., Photogeologic map, Aneth-l quadrangle, UtahColorado: (Unclassified). July 1952. (OF).

453. Hackman, R。 J., Photogeologic map, Elk Ridge-9 quadrangle, San Juan County, Utah: (Unclassified). July 1952. (OF).

454. Scott, J. B., Development drilling on the Vanura claims, San Miguel County, Colorado: (Official use only). September 1952.

455. Withington, C.F. and Scott, J. B., Development drilling on the Contact No. 4 claim, Gypsum Valley district, San Miguel County, Colorado: (Official use only). June 1953.

456. Sample, R. Do and Albee, H.F., Claim map, Egnar quadrangle, San Miguel County, Colorado: (Official use only). January 1953.

457. Sample, R. D. and Albee, I. F., Claim map, Joe Davis Hill quadrangle, San Miguel County, Colorado: (Official use only). January 1953.

458. Sample, $R_{0} D_{0}$, Albee, $H_{0} F_{0}$, and Stephens, $H_{0} G_{0}$, Claim map, Anderson Mesa quadrangle, Montrose and San Miguel Counties, Colorado: (Officiall use only). January 1953. 


\section{3}

459. Brasher, G。 $K_{0}$ and Douglas, $R, F$, Development drilling on the Gramlich group, Paradox district, Montrose County, Colorado: (Official use only). November 1952.

460. Mobley, C. Mo, Development drilling on the Pay Day group, Gypsum Valley district, San Miguel County, Colorado: (Official use on1y)。 January 1953.

461. Jobin, Do Ao, Preliminary report on exploration of the Dolores Bench, Montrose County, Colorado: (Official use only). January 1953.

462. Sample, R. Do and Albee, H. F., Claim map, Gateway quadrangle, Mesa County, Colorado: (Official use only). January 1953.

463. Sample, R。 D., Albee, H. F., and Stephens, H. G., Claim map, Horse Range Mesa quadrangle, San Miguel County, Colorado: (Ofificial use only). April 1953.

464. Cathcart, J。 B. and McGinley, F。 E., Reserves of leached-zone material that will be mined prior to January 1957, landwpebble phosphate field, Florida: (Confidential). July 1952.

465. Hackman, R. Jo, Photogeologic map, Mt. Peale-8 quadrangle, UtahColorado: (Unclassified). September 1952. (OF).

466. Hackman, R. J., Photogeologic map, Mt. Peale $=7$ quadrangle, San Juan County, Utah: (Unclassified). October 1952. (OF).

467. Hackman, $R, J_{0}$, Photogeologic map, Mt. Peale-1 quadrangle, Grand and San Juan Counties, Utah, Montrose County, Colorado: (Unclassified). October 1952. (OF).

468. Ray, R. G., Photogeologic map, Agathla Peak-7 quadrangle, Navajo Indian Reservation, Navajo County, Arizona: (Unclassified). October 1952. (OF)。

469. Fischer, W. A. and Condon, W. H., Photogeologic map, Navajo Mountain 9 quadrangle, Navajo Indian Reservation, San Juan County, Utah: (Unclassified). October 1952. (OF)。

470. Fischer, W. A. and Condon, W. H., Photogeologic map, Navajo Mountain= 16 quadrangle, Navajo Indian Reservation, San Juan County, Utah: (Unclassified). October 1952. (OF).

471. Dwornik, Edward and Ross, Malcolm, Application of the electron microw scope to mineralogic studies: (Official use only). October 1952.

472. Cathcart, J。B., Dxilling program for lands owned by Swift and Company near Fort Meade, land pebble phosphate district, Florida:

(Official use only). August 1952. 
473. Mackin, Hoover, Reconnaissance geology of the monazite placers of the Long Valley district, Idaho: (official use only). JuIy 1952.

474. Botinelly, Theodore, Summary report of the project "Mineralogy of the Chattanooga shale": (official use only). September 1952.

475. Berman, Robert, Summary report on public samples received during 1951, Trace Elements Section Washington Laboratory, Geochemistry and Petrology Branch: (Official use only). August 1952.

476. Fix, P. Fo, Progress report on uranium in natural waters: (Confidentialstestiricted Data). August 1952.

477. Cathcart, J. B., Blade, I. V., and Gray, $C_{0} \mathrm{H}_{0}$, Jr, Ieached-zone materia. in overburden dumps, Varn and Peace Valley mines, landw pebble phosphate district, Florida: (Officlal use only). January 1953.

478. A.tschuler, $Z$. S., Progress report on sampling of leached zone materials of Florida, for mineralogic and metallurgical study: (Confidential). August 1952.

479. Finne1I, T。 Io, Renzetti, B. Io, and Trites, A, F., Jro, Preliminary report on the geology of the Miger (Hideout) claim, White Canyon area, San Juan County, Utah, with recommendations for exploration for geologic information: (Official use only). October 1952.

480. Douglas, R. F, and Brasher, $G$. $K_{0}$, Development drolling in the Gray Daun area, Paradox district, San Juan County, Jtak: (Official use only). January 1953.

481. Jobin, D. A. and Schesslex, T. E., Interim report on exploration in the Atkinson Mesa area, Montrose County, Colorado: (Official use only). February 1953.

482. Cannon, H. I $L_{0}$ and Stillman, Ro Mo, Geobotanical recomaissance for uranium in the Temple Mountain district, Emery County, Utab: (Official use only). November 1952.

483. Cannon, H. L. and Still man, R, M. , Geobotanical reconnaissance for uranium in the Marysvale area, Piute County, Utah: (Official use only). November 1952.

484. Cannon, Ho Io and DurreII, Mo No, Geobotanical reconnaissance for uranium in the Great Divide Basin, Sweetwater County, Wyoming: (official use oniy). November 1952.

485. Emerick, W. I., Development drilling on the Iost group area, Gypsum Valley district, San Miguel County, Colorado: (official use only). August 1953. 
486. Bell, Kenneth G., Gammawray logging of hot holes in the northwest Carrizo Mountains area, Apache County, Arizona and San Juan County, Utah: (Official use only). March 1953.

487. Eicher, I. J., Interim report on exploration of the San Miguel Bench, Montrose County, Colorado: (Official use only). January 1953.

488. Eicher, I.J., Interim report on exploration of the Spring Creek Mesa, Montrose County, Colorado: (Official use only). March 1953.

489.

490. Brew, D. A., Development drilling on the American Eagle group, Gypsum Valley district, Montrose County, Colorado: (Official use only). Apri工 1953.

491. Stager, $H_{0} K_{0}$, Results of the Geological Survey's Colorado Plateau developmentwdrilling program for the period May 5 to December 13, 1952: (Official use only). January 1953.

492. Witkind, I. Jo, Thaden, R. E., and Lough, C. F., Interim report on geologic investigations in the Monument Valley ared, Arizona: (Official use only). January 1953.

493. Gualtieri, J. L., Development drilling on the Terrible group, Gypsum Valley district, Montrose County, Colorado: (Official use only). March 1953.

494. Vogel, J. D., Preliminary reserve statement 28, Reserve Blocks A and B, Jo Dandy area, Montrose County, Colorado: (Confidential). April 1953.

495. Douglas, R. Fo, Preliminary reserve statement 29, Reserve Block 8, Club Mesa, Montrose County, Colorado: (Official use only). March 1953.

496. Alvord, D. C., Preliminary reserve statement 30, Reserve Block A, San Miguel Bench, Montrose County, Colorado: (Official use only). June 1953.

497. Alvord, D. C., Preliminary reserve statement 3I, Reserve Blocks B and C, San Miguel Bench, Montrose County, Colorado: (Official use only). July 1953.

498. Brew, D. A., Preliminary reserve statement 32, Reserve Block A, Atkinson Mesa, Montrose County, Colorado: (Confidential). July 1953.

499. Fischer, W. A. and Condon, W. H., Photogeologic map, Shanto SpringmI quadrangle, Navajo Indian Reservation, Navajo County, Arizona: (Unclassified). September 1952. (OF). 
500. Ray, R. G., Photogeologio map, Orange Cliffs-13 quadrangle, Garfield County, Utah: (Unclassified). October 1952. (OF).

501. Ray, R. G., Photogeologic map, Orange Cliffs-14 quadrangle, Garfield County, Utah: (Unclassified). October 1952, (OF).

502. Overstreet, W. C., Areas in the western monazite belt, North and South Carolina, recommended for physical exploration by the U. S. Bureau of Mines: (Official use only). October 1952.

503. Klemic, Harry and Baker, Richard C., Preliminary summary of uranium occurrences in Carbon County, Pennsylvania.*

504. Dutro, H. B., Areal distribution, thickness, and uranium content of the Ieached zone and matrix in the Sydney area, Hillsborough County, Florida: (Official use only). January 1953.

505. Cathcart, J. B, and McGinley, F, E., Drilling program for lands owned by the American Agricultural Chemical Company in the Boyette and. South Pierce areas, land-pebble phosphate district, Florida: (Official use only). November 1952.

506. Ketner, K. B., Drilling program for lands owned by American Cyanamid Company, land-pebble phosphate district, Florida: (Official use only). November 1952 .

507. Bergendahl, M. H., Wavellite spherulites in the Bone Valley formation of central Florida: (Unclassified). February 1953. (NSA).

508. Stead, F. W., Balsley, J.R., Moxham, R. M., and Reinharat, P. W., Airborne radioactivity survey of the Pumpkin Buttes area, Campbell and. Johnson Counties, Wyoming: (Unclassified). February 1953. $(\mathrm{OF})$.

509. Manger, G. E. and Gates, G. I., Progress report on original-state core studies: (Unclassified). January 1953. (TIS; NSA).

510. Read, C. B., Sample, R. D., and Bachman, Go O., Notes on copperbearing sandstone beds in the southwestern United States.*

511. Raup, R. B., Jr., A leaduranium deposit at the thite Oak No. 1 mine, Santa Cruz County, Arizona: (Official use only). August 1953.

512. Campbell, $R_{\text {e }} H$, and Schafer, Max, A systematic radioactivity connaissance of part of the north Gilpin County mining district, Gilpin County, Colorado.* 
513. Erickson, R. L., Myers, A. T., and Horr, C. A., The association of uranium and other metals with crude oils, asphalts, and petroliferous rocks: (Unclassified). December 1952. (J-24).

514. Walker, G. W., Rosamond prospect, Kern County, California: (Pt. I, Unclassified; Pt. 2, Official use only). February 1953. (J-III).

515. Dings, McClelland G., Preliminary summary of reconnaissance for radioactive materials in the Garfield and Taylor Park quadrangles, Colorado: (Official use only). November 1952.

516. Dings, McClelland G*, Preliminary summary of reconnaissance for radioactive materials near Montezuma, Summit County, Colorado:

(Official use only). December 1952.

517.

518. Sheridan, D. M. Preliminary report on Lost Creek schroeckingerite area, Sweetwater County, Wyoming: (Official use only). January 1953.

519. Vickers, $R_{*} C_{*}$, Preliminary summary of reconnaissance for radioactive deposits in the north-central states: (Official use only). February 1953.

520. Sims, $P_{*} K_{*}$, Harrison, J. E., and Moore, F。 B., Preliminary report on 1952 investigations in the Colorado Front Range: (Official use only). December 1952.

521. Leonard, B. F., Preliminary summary on zonal relations of uranium deposits in metalliferous districts: (Official use only). December 1952 .

522. Armstrong, F. C., Preliminary report on regional reconnaissance for radioactive materials in the northwestern states during 1952: (Official use only). January 1953.

523. Ray, R. G., Photogeologic map, Orange Cliffs-ll quadrangle, Wayne and Garfield Counties, Utah: (Unclassified). December 1952. (OF).

524. Ray, R. G., Photogeologic map, Orange Cliffs-12 quadrangle, Wayne and Garfield Counties, Utah: (Unclassified). December 1952. (OF).

525. Hosley, $V_{0} M_{*}$, Photogeologic map, Orange Cliffs-5 quadrangle, Wayne County, Utah: (Unclassified). December 1952. (OF).

526. Hackman, R. J., Photogeologic map, Navajo Mountain-13 quadrangle, Navajo Indian Reservation, San Juan and Kane Counties, Utah: (Unclassified). October 1952. (OF). 
527. Hackman, R. J., Photogeologic map, Mt. Peale-4 quadrangle, Grand and. San Juan Counties, Utah: (Unclassified). December 1952. (OF).

528. Orkild, P. P., Photogeologic map, Stinking Spring Creek-5 quadrangle, Emery County, Utah: (Unclassified). November 1952. (OF).

529. Scott, J. M., Photogeologic map, Circle Cliffs -9 quadrangle, Garfield County, Utah: (Unclassified). November 1952. (OF).

530. Hemphill, $W . R_{0}$, Photogeologic map, Stinking Spring Creek-6 quadrangle, Emery County, Utah: (Unclassified). November 1952. (OF).

53I. Hackman, R.J., Photogeologic map, Circle Cliffs-10 quadrangle, Garfield County, Utah: (Unclassified). November 1952. (OF).

532. Orkild, P. P., Photogeologic map, Stinking Spring Creek-4 quadrangle, Emery County, Utah: (Unclassified). November 1952. (OF).

533. Faul, Henry, Gott, G. B., Manger, G. E., Mytton, J. W., and Sakakura, A. Y., Radon and helium in natural gas: (Unclassified). June 1953. ( J-29; NSA).

534. Osterwald, F. W. Preliminary notes on 1951-52 investigations of the Thomas Range fluorite district, Juab County, Utah: (Official. use only). November 1952.

535. Trimble, D. E. and Lewis, R。 Q., Sr., Preliminary report on geologic studies in Monument Valley, San Juan County, Utah, 1952: (Official use only). January 1953.

536. Witkind, I. J., Thaden, R。 E., and Lough, C. F., Preliminary report on geologic investigations in Monument Valley area, Arizona, 1952: (Official use only). February 1953. (OF).

537. Mullens, T. E. and Hubbard, H. A., Preliminary report on geologic studies in the Red House Cliffs area, San Juan County, Utah: (Official use only). December 1952.

538. Smith, J. F., Jr., Hinrichs, E. N $N_{0}$, Huff, I. C., and Luedke, R. G., Preliminary report on geologic studies in the Capitol Reef area, Wayne County, Utah, 1952: (Official use only). January 1953.

539. Overstreet, W. C., Further areas in the western monazite belt of South Carolina recommended for physical exploration by the U. S. Bureau of Mines: (Official use only). December 1952.

540. Trites, A. F., Jr., and Finnell, T. I., Preliminary report on geologic investigations in White Canyon, San Juan County, Utah, 1952:

(Official use only). January 1953.

541. Eckstein, W. H., Photogeologic map, Agathla Peak-6 quadrangle, Navajo Indian Reservation, Navajo County, Arizona: (Unclassified). November 1952. (OF). 
542. Orkild, P. P., Photogeologic map, Stinking Spring Creek-3 quadrangle, Emery County, Utah: (Unclassified). December 1952. (OF).

543. Hemphill, W. R., Photogeologic map, Stinking Spring Creek-10 quadrangle, Emery County, Utah.*

544. Hosley, $V . M_{*}$, Photogeologic map, Carlisle $=5$ quadrangle, Wayne and San Juan Counties, Utah: (Unclassified). January 1953. (OF).

545. Orkild, P. P., Photogeologic map, Stinking Spring Creek*15 quadrangle, Emery County, Utah: (Unclassified). December 1952. (OF).

546. Condon, W。 H., Photogeologic map, Emery 16 quadrangle, Emery County, Utah: (Unclassified). December 1952. (OF).

547. Hosley, V. M., Photogeologic map, Carlisle -4 quadrangle, Wayne and San Juan Counties, Utah: (Unclassified). December 1952. (OF).

548. Hackman, R. J., Photogeologic map, Circle Cliffs-2 quadrangle, Garfield County, Utah: (Unclassified). August 1953. (OF).

549. Scott, J.M., Photogeologic map, Circle Cliffs-3 quadrangle, Garfield County, Utah: (Unclassified). January 1953. (OF).

550. Hemphill, $W_{\diamond} R_{\circ}$, Photogeologic map, Stinking Spring Creek-7 quadrangle, Emery County, Utah: (Unclassified). January 1953. (OF).

551. McKeown, F. A。 and Klemic, Harry, Preliminary report on reconnaissance for radioactive materials in the northeastern United States: (Official use only). January 1953.

552. Wedow, Helmuth, Jr., Bates, R. G., Grantz, Arthur, Houston, J. R., Killeen, P. L., Matzko, J. J., Nelson, A.E., Ste jer, F. A., Velikanje, R. S., and West, W. S., Preliminary summary of reconnaissance for uranium and thorium in Alaska, 1952: (Official use only). December 1952. (C-248).

553. Swanson, V. E., Preliminary sunmary of investigations of Chattanooga shale in 1952: (Official use only). December 1952.

554. Walker, George W., Preliminary report on the regional reconnaissance for radioactive materials in California during 1952: (Official use only). January 1953.

555. Vine, James $D_{0}$, Investigations in the Fall Creek area, Bonneville County, Idaho, during the 1952 field season - a preliminary report: (Official use only). November 1952.

556. Zeller, Howard. D. and. Baltz, Elmer H., Jr., Uranium-bearing copper deposits in the Coyote mining district, Mora County, New Mexico: (Official use only). December 1952. 
80

557.

558. Vickers, R. C., Preliminary report on the monazite-bearing Goodrich quartzite, Palmer area, Marquette County, Michigan: (Official use only). April 1953.

559. Vickers, R. C., An occurrence of autunite, Lawrence County, South Dakota: (Pt. 1, Unclassified; Pt. 2, Official use only). January 1953. $(\mathrm{C}-286)$.

560. Sharp, W。 No and Cavender, W. S., Preliminary summary report on geology and thorium deposits of the Lemhi Pass district, Idaho and Montana: (Official use only). February 1953.

561.

562.

563.

564.

565.

566.

567.

568.

569. 
570.

571.

572. Troyer, M. L., McKay, E. J., and Soister, P. I., Preliminary report on results of field investigations for uraniferous deposits in the Pumplin Buttes area, Johnson and Campbell Counties, Wyoming: (Official use only). December 1952.

573. Davidson, David F., Preliminary report of the results of reconnaissance for uraniferous materials in the Powder River Basin, Wyoming: (Official use only). February 1953.

574. Barge, E. M., Development drilling on the Sunset claim, Gypsum Valley district, San Miguel County, Colorado: (Official use only). September 1953.

575. Cannon, H. I., Geobotanical reconnaissance for uranium on La Ventana Mesa, Sandoval County, New Mexico: (Official use only). March 1953.

576. Madsen, J.W., Development drilling on the Rambler group, Gypsum Valley district, Montrose County, Colorado: (Official use only). June 1953.

577. Witkind, I. J., Thaden, R. E., and Lough, C. F., Reconnaissance for a geophysical survey and a diamond-drilling program on Mitchell Mesa, Monument Valley area, Arizona.*

578. Black, R. A. Geophysical investigations on the Gramlich group, Paradox district, Montrose County, Colorado: (Official use only). March 1953.

579. Cannon, H. I., Interim report on geobotanical results in the Yellow Cat area, Thompsons district, Grand County, Utah.*

580. Narten, P. F. and Starrett, W. H., Preliminary report on geobotanical prospecting, Valencia and McKinley Counties, New Mexico: (Official use only). May 1953.

581. Carter, W. D., Interim report on diamond-drill exploration and plans for additional drilling in the Long Park area, Montrose County, Colorado: (Confidential). April 1953. 
582. Okerlund, $M_{0}$ D. Interim report on exploration in the Yellow Cat area, Grand County, Utah: (Official use only). May 1953.

583. Shoemaker, E. M., Reconnaissance geology of the Ute Mountains, Colorado.*

584. Hosley, V. M., Photogeologic map, Moab-14 quadrangle, Grand County, Utah: (Unclassified). January 1953. (OF).

585. Hackman, R. J., Photogeologic map, Circle clifis-6 quadrangle, Garfield County, Utah: (Unclassified). December 1952. (OF).

586. Scott, J. $M_{0}$, Photogeologic map, Circle Cliffs-1 quadrangle, Garfield County, Utah: (Unclassified). January 1953. (OF).

587. Bates, C. E., Photogeologic map, Carlisle-6 quadrangle, San Juan County, Utah: (Unclassified). May 1953. (OF).

588. Condon, W. H., Photogeologic map, Emery-9 quadrangle, Emery County, Utah: (Unclassified). April 1953. (OF).

589. Hemphill, W. R., Photogeologic map, Stinking Spring Creek-2 quadrangle, Emery County, Utah: (Unclassified). January 1953. (OF).

590. Hackman, $R_{0} J_{0}$, Photogeologic map, Circle Cliffs -7 quadrangle, Gr field County, Utah: (Unclassified). Januery 1953. (OF).

591. Orkild, P. P., Photogeologic map, Emery-1 quadrangle, Emery County, Utah: (Unclassified)。 March 1953. (OF)。

592. Bates, C.E., Photogeologic map, Carlislew3 quadrangle, San Juan County, Utah: (Unclassified). January 1953. (OF).

593. Condon, W. H., Photogeologic map, Emery 8 quadrangle, Emery County, Utah: (Unclassified). March 1953. (OF).

594. Orkild, P.P., Photogeologic map, Orange Cliffs-3 quadrangle, Wayne County, Utah: (Unclassified). January 1953. (OF).

595. Scott, J. M., Photogeologic map, Circle Cliffs=8 quadrangle, Garfield County, Utah: (Unclassified). March 1953. (OF).

596. Hackman, R. J., Photogeologic map, Mt. Pennell-5 quadrangle, Garfield County, Utah: (Unclassified). March 1953. (OF).

597. Scott, J. M. Photogeologic map, Mt. Pennell-12 quadrangle, Garfield Councy, Utah: (Unclassified). February 1953. (OF).

598. Hosley, V. M., Photogeologic map, Moab-15 quadrangle, Grand County, Utah: (Unclassified). March 1953. (OF). 
599. Hemphill, W. $R_{3}$, Photogeologic map, Orange Cliffs 6 quadrangle, Wayne County, Utah: (Unclassified). August 1953.

600. Orkild, P. P. Photogeologic map, Orange Cliffs -2 quadrangle, Wayne County, Utah: (Unclassified). March 1953. (OF).

601. Masursky, Harold and Pipiringos, George N., Uranium-bearing coal in the Red Desert, Great Divide Basin, Sweetwater County, Wyoming: (Official use only). March 1953.

602. Mackin, Hoover and Schmidt, Dwight L., Reconnaissance geology of placer deposits containing radjoactive minerals in the Bear Valley district, Valley County, Idaho: (Pt. I, Unclassified; Pt. 2, Official use only). January 1953. (J-68; OF).

603. Becraft, George E., The Comet and Gray Eagle mines and adjacent areas, Jefferson County, Montana: (Official use only). March 1953.

604. Altschuler, Z. S., Berman, Robert, Owens, J. T., Delevaux, M. H., and. Lundine, So, Fractionation studies of millisite-pseudowavellite rock from the leached zone at Homeland, Florida: (Confidential). April 1953.

605. Henderson, $J \circ R_{0}$ and Moxham, R. M., Airborne radioactivity survey of the Devil's Tower area, Crook County, Wyoming: (Unclassified). February 1953. (OF; NSA).

606. Meuschke, J. I. and Moxham, R. M., Airborne radioactivity survey of the Miller Hill area, Carbon County, Wyoming: (Unclassified). February 1953. (OF).

607. Johnson, R. W. and Moxham, R. M., Airborne radioactivity survey of portions of the Defiance Uplift and Carrizo Mountains, Apache County, Arizona: (Unclassified). April 1953. (OF).

608. Keller, G. V., Progress report on petrophysical studies of the Morrison formation: (Official use only). February 1953.

609. Meuschke, J。 I。 and Moxham, R. M。, Airborne radioactivity survey of the Aspen Mountain area, Sweetwater County, Wyoming: (Unclassified). April 1953. (OF).

610. Meuschke, J. I. and Moxham, R. M., Airborne radioactivity survey of the Tabernacle Buttes area, Sublette and Fremont Counties, Wyoming: (Unclassified). March 1953. (OF).

611. Meuschke, J. I. and Moxham, R. M., Airborne radioactivity survey of the West Lonetree area, Uinta County, Wyoming: (Unclassified). March 1953. (OF).

612. Hemphill, W. R., Photogeologic map, Orange Cliffs-7 quadrangle, Wayne County, Utah: (Unclassified). March 1953. (OF). 
84

613. Hackman, R. J., Photogeologic map, Mt. Penne11-14 quadrangle, Gerfield and Kane Counties, Utah: (Unclassified). March 1953. (OF).

614. Hackman, R. J., Photogeologic map, Circle Cliffs-16 quadrangle, Garfield and Kane Counties, Utah: (Unclassified). March 1953. $(\mathrm{OF})$.

615. Scott, J.M., Photogeologic map, Mt. Pennell-13 quadrangle, Garfield and Kane Counties, Utah: (Unclassified). April 1953. (OF).

616. Bates, C. E, Photogeologic map, Moab-10 quadrangle, Grand County, Utah: (Unclassified). April 1953. (OF).

617. Orkild, P. P., Photogeologic map, Tidwell-16 quadrangle, Emery and Grand Counties, Utah: (Unclassified). April 1953. (OF).

618. Condon, W. H., Photogeologic map, Orange Cliffs-10 quadrangle, Wayne and Garfield Counties, Utah: (Unclassified). April 1953. (OF).

619. Scott, J. M., Photogeologic map, Navajo Mountain-4 quadrangle, Kane County, Utah: (Unclassified). April 1953. (OF).

620. Scott, J. M., Photogeologic map, Navajo Mountain 6 quadrangle, San Juan and Kane Counties, Utah: (Unclassified). August 1953. (OF).

62I. Hackman, R. J., Photogeologic map, Navajo Mountain-3 quadrangle, Kane and San Juan Counties, Utah: (Unclassified). April 1953. (OF).

622. Wedow, Helmuth, Jr., Analysis of samples from properties of the Baranof Exploration and Development Company, Chichagof district, southeastern Alaska: (Official use only). March 1953.

623. Barge, E. M., Development drilling on the Early Morn group of claims, Gypsum Valley district, San Miguel County, Colorado: (Official use only). September 1953.

624.

625. Emerick, W. I. and Gualtieri, J. I., Development drilling on the Georgetown group, Slick Rock district, San Miguel County, Colorado: (Official use only). August 1953.

626. Millgate, M. I., Development drilling in the Joker group, Gypsum Valley district, Montrose County, Colorado: (Official use only). June 1953.

627. Jackson, W. H., Preliminary report on geophysical investigations of the Deer Flat area, White Canyon district, San Juan County, Utah.* 
628. Alvord, D. C., Preliminary report on exploration of the San Misuel bench, Montrose County, Colorado: (Official use only). May 1953.

629. Chew, $R_{0} T_{0}$, III, Preliminary report on radioactivity in modern stream gravels。*

630. Dutro, H。 B., Development drilling on the Pooch group, Gypsum Valley district, Montrose County, Colorado: (Official use only). August 1953.

631. Madsen, J. Wo, Development drilling on the Pitchfork group of claims, Gypsum Valley district, San Miguel County, Colorado.*

632. Strobell, J. D., Jr., Sample, R. D., Stephens, H. G., and Gilbert, Cyothia C., Preliminary analysis of ore distribution in the Gate way and Uravan districts, Mesa and Montrose Counties, Colorado**

633. Scott, Jo Mo, Photogeologic map, Mt. Pennell=ll quadrangle, Garfield County, Utah: (Unclassified). April 1953. (OF).

634. Scott, J. M., Photogeologic map, Circle Cliffs 4 quadrangle, Garfield. County, Utah: (Unclassified). August 1953. (OF).

635. Scott, J. Mo, Photogeologic map, Circle Cliffs -5 quadrangle, Garfleld County, Utah: (Unclassified). April 1953. (OF).

636. Hackman, R. J., Photogeologic map, Circle Cliffswil quadrangle, Garfield County, Utah: (Unclassified). April 1953. (OF)。

637. Hackman, $R_{0} J$ o, Photogeologic map, Circle Cliffs 14 quadrangle, Garfield and Kane Counties, Utah: (Unclassified)。 April 1953. (OF)

638. Hosley, $V_{0} M_{0}$, Photogeologic map, Straight Cliffs = I quadrangle, Kane County, Utah: (Unclassified), May 1953. (OF)。

639. Hosley, V. Mo, Photogeologic map, Moab-12 quadrangle, Grand County, Utah: (Unclassified). June 1953. (OF).

640. Hackman, R。 J. and Tolbert, G. E., Photogeologic map, Notom 15 quade rangle, Garfield County, Utah: (Unclassified). June 1953. (OF).

641. Hackman, R。 J., Photogeologic map, Circle Cliffs-15 quadrangle, Gar field and Kane Counties, Utah: (Unclassified)。 May 1953。 (OF). 
642. Oxkild, P. P., Photogeologic map, Tidwe11-5 quadrangle, Emery County, Utah: (Unclassified). May 1953. (OF).

643. Huff, Iyman C., Preliminary geochemical studies in the Capitol Reef area, Wayne County, Utah.*

644. Moxham, R. M. and Johnson, R. W., Airborne radioactivity survey of parts of the Atlantic Ocean beach, Virginia to Florida: (Unclassified). May 1953. (OF).

645. Trites, A. F., Jr., and Chew, R. T., III, Preliminary report on the Happy Jack mine, San Juan County, Utah.*

646. Finne1I, T. I., Structural control of ore deposits at the Monument No. 2 mine, Arizona.*

647. Stern, T. W. and Stieff, I. Ro, Preliminary description of coffinitew a new uranium mineral: (Unclassified). October 1953.

648. Thompson, R. Bruce, Jr., Summary report on public samples received 1949 51. Trace Elements Section Washington Laboratory, Geochemistry and Petrology Branch: (Official use only). November 1952.

649. Conant, I. C. and Rowe, J. J., Proposed investigations of Chattanooga. shale in fiscal year 1954: (Official use only). May 1953.

650. Hemphill, W. R., Photogeologic map, Stinking Spring Creek-9 quadrangle, Emery County, Utah: (Unclassified). July 1953. (OF).

651. Kent, B. H., Photogeologic map, Desert Lake-14 quadrangle, Emery County, Utah: (Unclassified). May 1953. (OF).

652. Bates, C. E。, Photogeologic map, Moab-11 quadrangle, Grand County, Utah: (Unclassified). September 1953. (OF).

653. Kent, B. H. and Condon, W. H., Photogeologic map, Orange Cliffs $=15$ quadrangle, Garfield and San Juan Counties, Utah.**

654. Hemphill, w. R., Photogeologic map, Orange Cliffs 8 quadrangle, Wayne and San Juan Counties, Utah: (Unclassified). May 1953. (OF).

655. Orkild, P. P., Photogeologic map, Tidwell-4 quadrangle, Emery County, Utah: (Unclassified). August 1953. (OF).

656. Hosley, $\nabla_{0} M_{0}$, Photogeologic map, Tidwell-15 quadrangle, Emery County, Utah: (Unclassified). June 1953. (OF). 


\section{7}

657. Hemphill, W. R., Photogeologic map, Stinking Spring Creek 8 quadrangle, Emery County, Utah: (Unclassified). August 1953. (OF).

658. Kent, B. H., Photogeologic map, Desert Lake-1l quadrangle, Emery County, Utah: (Unclassified). August 1953. (OF).

659. Orkild, P. P., Photogeologic map, Woodside-13 quadrangle, Emery County, Utah: (Unclassified). August 1953. (OF).

660. Bates, C. E. and Hosley, V. M., Photogeologic map, Tidwell-a quadrangle, Emery and Grand Counties, Utah: (Unclassified). August 1953. (OF).

661. Scott, J.M., Photogeologic map, Kaiparowits Peak-8 quadrangle, Garfield County, Utah: (Unclassified). September 1953. (OF).

662. Scott, J. M., Photogeologic map, Straight Cliffs-2 quadrangle, Kane County, Utah: (Unclassified.). July 1953. (OF).

663. Scott, J. M., Photogeologic map, Kaiparowits Peak 9 quadrangle, Carfield County, Utah: (Unclassified). August 1953. (OF).

664. Concion, W. H., Photogeologic map, Orange Cliffs 4 quadrangle, Wayne County, Utah: (Unclassified). September 1953. (OF).

665. Orkild, P. P. Photogeologic map, Orange Cliffs-l quadrangle, Wayne and San Juan Counties, Utah: (Unclassified). August 1953. (OF).

666.

667. Scott, J. Mo, Photogeologic map, Carlisle-2 quadrangle, San Juan County, Utah.*

668. Hackman, R.J., Photogeologic map, Carlisle-15 quadrangle, San Juan County, Utah: (Unclassified). September 1953.

669. Scott, J.M. , Photogeologic map, Carlislew10 quadrangle, San Juan County, Utah: (Unclassified). September 1953.

670. Narten, P. F., Preliminary report on the results of geobotanical prospecting on the south flank of Haystack Butte, McKinley County, New Mexico: (Official use only). April 1953.

671. Sears, J.D. and Sample, R. D. (mapped under supervision of), Preliminary geologic map of the Comb Ridge area, San Juan County, Utah (BIuff I NW, I SW, and $4 \mathrm{NW}, 7 \frac{1}{2}-$ minute quadrangles).* 
672. Cathcart, J. Bo and Ward, E. I. Mo, Ownership maps of perts of Hillsborough and Polk Counties, land-pebble phosphate district, Florida: (Unclassified). May 1953. (OF).

673. Meuschke, J。 $I_{0}$, Moxhar, $R_{\odot} M_{\infty}$, and Bortner, T. E., Airborne radiow activity survey of parts of the Atlantic Ocean Beach, North and South Carolina: (Unclassified). November 1953.

674. Walker, George $W_{0}$, Regional reconnaissance for radioactive materials in eastern Imperial County, California: (official use only). June 1953.

675. Gillerman, Elliot, Gammamay logging in the Tyrone, White Signal, and. Black Hawk districts, Grant County, New Mexico: (Official use only). May 1953.

676. Davidson, David F。, Distribution of coarse and fine-grained rocks in the Wasatch formation and their relationship to uranium deposits, Powder River Basin, Wyoming: (Unclassiried). May 1953. (TIS; NSA).

677. Davidson, David F., Reconnaissance for uranium in the Powder River Basin, Wyoming: (Unclassified). May 1953. (TIS; NSA).

678. Meuschke, J。 Io, Moxharn, R。 Mo, and Bortner, T。 E。, Airborne radioactivity survey of the Gulf of Mexico beach, between Sanibel Island and Caladesi Island, Florida.**

679. Raup, $R_{0} B_{0}, J r_{0}$, and Haines, $D_{0} V_{0}$, Reconnaissance for radioactivity in the Yuma Air Force Base gunnery range, Yuma County, Arizona.*

680. Barge, E. Mo, Development drilling on the Tiny claim, Gypsum Valley district, San Miguel County, Colorado: (Official use only). September 1953.

681. Dutro, $H_{0} B_{0}$ and Bivens, N. $W_{0}$, Development drilling on the Spectacle Point claim, Gypsum Valley district, San Miguel County, Colorado: (Official use only). September 1953.

682. Dutro, $H_{\circ} B_{0}$ and Bivens, $N_{0} W_{\circ}$, Development drilling on the Long Ridge group of claims, Gypsum Valley district, San Miguel County, Colorado: (Official use only). October 1953.

683. Emerick, W。 I. and Gualtieri, Jo I., Development drilling in the Ellison Burro claims area, Slick Rock district, San Miguel County, Colorado: (Official use only). November 1953. 
89

684. Emerick, Wo I. and Gualtieri, J. I., Development drilling on the Upper group area, Slick Rock district, San Miguel County, Colorado.*

685. Emerick, H. I. and Gualtieri, J. I., Preliminary reserve statement 33, Reserve Block 1, South Radium group area, Slick Rock disw trict, San Miguel County, Colorado: (Official use only). September 1953.

686. Bowers, Howard, Preliminary reserve statement 34 , Reserve Block E, Long Park area, Uravan district, Montrose County, Colorado,*

687. Gualtieri, J. I. and Emerick, W. I., Development drilling in the Hawkeye claim area, Slick Rock district, San Miguel County, Colorado: (Official use only). October 1953.

688. Roach, C. H., Preliminary report on exploration of the Spring Creek Mesa area, Montrose County, Colorado: (Official use only). September 1953.

689. Emerick, W。 Io and Gualtieri, J. I, Interim report on drilling in the Slick Rock district, San Miguel County, Colorado.*

690. Cater, F.W., Jr., Geology of the Anderson Mesa quadrangle, Colorado, with a sertion on "The Mines" by C.F. Withington.* (OM)*

691. McKay, E. J., Geology of the Atkinson Creek quadrangle, Montrose County, Colorado.* (QM).*

692. Cater, F. W. Jr., Geology of the Bull Canyon quadrangle, Montrose and San Miguel Counties, Colorado.* (QM).*

693. Cater, F.W., Jro, Geology of the Calamity Mesa quadrangle, Mesa County, Colorado, with a section on "The Mines" by Harold K. Stagex.* (QM)*

694. Cater, F. W. Jro, Geology of the Davis Mesa quadrangle, Colorado, with a section on "The Mines" by Leonid Bryner.* (QM).* 
695. Cater, $F$. Wo, Jr., Geology of the Egnar quadrangle, San Miguel and Dolores Counties, Collorado, with a section on "The Mines" by A. I. Bush and Henry Be11, III.* (QM)*

696. Cater, F。 W. Jr。, Geology of the Gateway quadrangle, Mesa County, Colorado* (QM)*

697. Cater, F. W., Jr., Geology of the Gypsur Gap quadrangle, Colorado.* $(\mathrm{QM}) \cdot *$

698. Cater, F. W. Jr., Geology of the Hamm Canyon quadrangle, Colorado.* $(\mathrm{Or})$.* $^{*}$

699. Cater, F. W., Jr., Geology of the Horse Range Mesa quadrangle, Colorado, with a section on "The Mines" by A. L. Bush, Henry Bell, III, and C. F. Withington.* (QM)。*

700. Cater, F. W., Jr., and Bell, Henry, III, Geology of the Joe Davis Hill quadrangle, Dolores and San Miguel Counties, Colorado.* $(\mathrm{QM}) *$

701. Shoemaker, E. Mv , Geology of the Juanita Arch quadrangle, Mesa County, Colorado.* (QM)*

702. Cater, F, W, Geology of the Naturita NW quadrangle, Colorado, with a section on "The Mines" by J. D. Vogel。* (QM)*

703. Withington, C. F., Geology of the Paradox quadrangle, Colorado.* (QM)*

704. Cater, F. W., Jr., Geology of the Pine Mountain quadrangle, Mesa County, Colorado: (Unclassified). August 1953. (QM)*.

705. McKay, E. J., Geology of the Red Canyon quadrangle, Montrose County, Colorado, with a section on "The Mines" by D. A. Jobin.* (QM)* 
706.

707.

708. Love, J, D., Uranium in the Gas Hills area, Fremont and Natrona Counties, Wyoming a preliminary report: (Pt. 1, Unclassified; Pt. 2, Official use only). October 1953.

709. Neuerburg, George J. ard Gottfried, David, Age determinations of the San Gabriel anor thosite massif.*

710. Jackson, $W_{*} H_{0}$, Geophysical investigations of the Happy Jack mine area, San Juan County, Utah.*

711. Starrett, W. Ho and Cannon, H. L, Geobotanical prospecting for uranium on La Ventana Mesa, Sandoval County, New Mexico.*

712. Lewis, $R, Q_{*}$, Appraisal and recomendations for drilling on Holiday Mesa, Monument Valley, Utah。*

713. Lewis, R, Q. and Reitan, P, H., Geologic appraisal and recommendations for exploration at Burch Canyon, Elk Ridge, San Juan County, Utah.*

714. Krumme1, W.J. and Lewis, R。Q., Preliminary report on Elk Ridge mapping.*

715. Carter, W. D, Development drilling on the Vanadium queen group of claims, Paradox district, San Juan County, Utah,*

716. Cadigan, R. A., A field method for making a quantitative estimate of silicified tuff in sandstone.* 
717. Roach, C. H., Preliminary reserve statement 35. Reserve Block A, Spring Creek Mesa area, Montrose County, Colorado: (Officlal use only). October 1953.

718. Roa.ch, C. H., Preliminary reserve statement 36, Reserve Blocks B and C, Spring Creek Mesa, Montrose County, Colorado: (Official use only). November 1953.

719. Roach, C. H., Preliminary reserve statement 37, Reserve Block D, Spring Creek Mesa, Montrose County, Colorado: (Official use only). November 1953.

720.

721.

722.

723. Mobley, C. Mo, Preliminary report on exploration in the Yellow Cat area, Grand County, Utah.*

724. Carter, W. D., Development drilling on the Hesperus claim, La Sal Creek area, Paradox district, San Juan County, Utah.*

725. Vogel, J. D. and Elston, D. P., Interim report on exploration in the Jo Dandy area, Montrose County, Colorado.*

726.

727. Eicher, I. J. and Myers, A. R., Interim report on exploration of the Beaver Mesa area, Mesa County, Colorado, and Grand County, Utah.* 
93

729.

730.

731. Eckstein, W. H., Photogeologic map, Moab-13 quadrangle, Grand and Emery Counties, Utah.*

732. Condon, W. H., Photogeologic map, Orange Cliffs-9 quadrangle, Garfield and Wayne Counties, Utah.*

733.

734.

735.

736.

737. Cass, J. T., Photogeologic map, Desert Lake-9 quadrangle, Emery County, Utah.*

738.

$739_{*}$

740. Vickers, $R, C$, Uranium occurrences in the Bald Mountain mining district, Lawrence County, South Dakota.* 
94

741. Vickers, $R$ 。 C., An occurrence of an unidentified $U$ mineral, Baraga County, Michigan.*

742. Vickers, R. C., Reconnaissance for radioactive deposits associated with the nepheline syenite complex near Wausau, Marathon County, Wisconsin。*

743. Henderson, J. R., Airborne radioactivity survey of parts of Baggs SW and. SE quadrangles, Carbon and Sweetwater Counties, Wyoming.*

744. Henderson, J. R, Airborne radioactivity survey of parts of Sand Creek SE and SW quadrangles, Carbon County, Wyoming.*

745. Henderson, J. R., Airborne radioactivity survey of parts of Savery $\mathrm{SE}$ and SW quadrangles, Carbon County, Wyoming,*

746. Henderson, J. R., Airborne radioactivity survey of parts of Saratoga $\mathrm{SE}$ and SW quadrangles, Carbon County, Wyoming.*

747. Henderson, J. R., Airborne radioactivity survey of parts of Savery NE and NW quadrangles, Carbon County, Wyoming.*

748. Johnson, R. W., Airborne radioactivity survey of parts of Harney Peak and Hermosa quadrangles, Custer County, South Dakota.*

749.

750. 
PART II。 TRACE ELENENTS AND REIATED REPORTS

AVAILABIE TO THE PUBLIC

Many U.S. Geological Survey Trace Elements / and related reports have been made available to the public, either by open-file release, reproduction and distribution by the Technical Information Service (referred to as TIS) of the U. S. Atomic Energy Commission, or publication by the Geological Survey or in a scientific journal.

The following list is a reference guide to Geological Survey Trace Elements reports that are available to the public, through December 31, 1953. These reports are listed according to the type of publication or release.

\section{REPORTS REIEASED IN OPEN FILE}

(* Indicates report is in preparation.)

These reports may be consulted at the U. S. Geological Survey Library, Room 1033, GSA Building, Washington 25, D. C., and at various depositories, whose addresses are indicated after the date of open file, either by symbol, or complete address. Symbols are used for the following depositories:

B - Office of the Director, Montana Bureau of Mines and Geology, Butte, Montana

BA - Atomic Energy Commission, Butte Suboffice, Butte, Montana

D - Geological Survey Public Inquiries Office, Room 468 New Customhouse, Denver, Colorado

DA - Atomic Energy Commission, Denver Exploration Branch, Denver Federal Center, Denver, Colorado

GJ - Geological Survey, Grand Junction, Colorado

GJA - Atomic Energy Commission, Grand Junction Operations Office, Grand Junction, Colorado

\section{(Symbols continued on next page)}

\footnotetext{
I Reports prepared by the Geologic Division of the Geological Survey on behalf of the Division of Raw Materials and the Division of Research of the U.S.Atomic Energy Commission. (TEI - Trace Elements Investigations Report; TEM - Trace Elements Memorandum Report; reports with no TE designation are not numbered into the Trace Elements Reports Series.)
} 
H - Atomic Energy Commission, Hot Springs Suboffice, Hot Springs, South Dakota.

IM - Idaho Bureau of Mines and Geology, Moscow, Idaho

NY - Atomic Energy Commission, New York Raw Materials Office, New York, New York

R - Atomic Energy Commission, Richfield Suboffice, Richfield, Utah

SF - Geological Survey Public Inquiries Office, Room 724, Appraisers Building, San Francisco, California

SL - Geological Survey Public Inquiries Office, Room 504, Federal Building, Salt Lake City, Utah

SLA - Atomic Energy Commission, Salt Lake Exploration Branch, Salt Lake City, Utah

T - Arizona Bureau of Mines, University of Arizona, Tucson, Arizona

U - University of Utah, Salt Lake City, Utah

W - Geological Survey, S. 157 Howard St., Spokane, Washington

\section{a. Trace Elements Investigations Reports}

TEI

47. Grimaldi, $F_{\circ} S_{\circ}$ and Levine, Harry, The rapid fluorimetric determination of uranium in low-grade ores, a preliminary report: Oct. 12, 1950.

71. Hinrichs, E. No, The pegmatites of the Errington-Thiel mine, Elko County, Nevada: Dec. 28, 1949: Office of Dr. Jay Carpenter, Director, Nevada Bureau of Mines, Reno, Nev。; Cornell University Library, Ithaca, N。 Y。

104. Fletcher, M。 H。, May, Irving, and Slavin, Morris, A transmission fluorimeter for use in the fluorimetric method of analysis for uranium: Oct.12, 1950。

109. Fischer, R。 Po, The Uravan mineral belt: July 7, 1951: SL; GJ。 (Superseded by $B-988-A$ )。

118. Silverman, $S_{0} R_{0}$, Fuyat, $R_{0} K_{0}$, and Weiser, $J_{0} D_{0}$, The quantitative determination of calcite associated with carbonate-bearing apatites: Oct. 19, 1951: SL; T; D。 (Superseded by Am。 Mineralogist, v. 37 , pp. 211-222, 1952).

120. Fletcher, M。 H. and May, Irving, An improved fluorimeter for the determination of uranium in fluoride melts: Oct。12, 1950.

127. Stieff, I。 R. and Stern, T。 Wo, The preparation of nuclear-track plates and stripping films for the study of radioactive minerals: Feb. 26, 1951. (Superseded by Am。 Mineralogist, v。37, pp。184-196, 1952)。

129. Stern, T. W., A catalog of study material of radioactive minerals: Oct. 19, 1951: SL; T; D。

133. Fletcher, $M_{\circ} H_{0}$, May, Irving, and Anderson, $J_{0} W_{0}$, The design of the Model V transmission fluorimeter: Oct. 19, 1951: SL; T; D。 
TEI

138. Staatz, M. H. and Trites, A. F., Jr., Geology of Quartz Creek pegna tite district, Gunnison County, Colorado: July 15, 1952: D; SL; Columbia University Library, New York, N. Y.

139. Thurston, W. R., Pegmatites of the Crystal Mountain district, Larimer County, Colorado: July 15, 1952: D; SL; Columbia University Library, New York, N.Y.

144. Phair, George and Onoda, Kiyoko, Hydrothermal uranothorite in fluorite breccias from the BIue Jay mine, Jamestown, Boulder County, Colorado: Oct. 19, 1951: SL; "T; D. (Superseded by Am. Mineralogist, v. $37, \mathrm{pp} .659-666,1952)$.

148A. Rabbitt, J, C., Summary of the research work of the Trace Elements Section, Geochemistry and Petrology Branch, for the period April 1, $1948-$ December 31, 1950: Oct. 19, 1951: SL; T; D.

151. Rabbitt, J. C., Summary of the research work of the Trace Elements Section, Geochemistry and Petrology Branch, for the period January $1-$ March 31, 1951: Oct. 19, 1951: SL; T; D.

152. Cuttitta, Frank, A photometric method for the estimation of the oil yield of oil shale: Oct. 19, 1951: SL; T; D. (Superseded by $\mathrm{B}=992$ ).

168. Kaiser, E. P., King, R. U., Wilmarth, V. R, Stugard, Frederick, Jr。, Wyant, $D_{0} G_{0}$, Gott, G. B., and others, Selected papers on uranium deposits in the United States: June 10, 1952: SL: D. (Superseded by $(-220)$.

176. Wilmarth, V. R. and Vickers, R. C., The Robinson and Weatherly uraniferous pyrobitumen deposits near Placerville, San Miguel County, Utah: Sept. 16, 1953: D; GJ.

183. McKelvey, V. E., Davidson, D. F., O'Malley, F. W., Smith, I. E., Armstrong, F, $C_{0}$, and Sheldon, R. P., Stratigraphic sections of the Phosphoria formation in Idaho, 1947-48, Part I: Aug. 15, 1951: W: SI; IM: U: B; Geol. Survey, Montpelier, Idaho; Wyoming Geol. Survey, Laramie, Wyo. (Superseded by C-208).

184. McKelvey, V. E., Smith, I. E, Hoppin, R. A, and Armstrong, F. C., Stratigraphic sections of the Phosphoria formation in Wyoming, 1947-48: Aug. 15, 1951: U; W; SL; IM; B; Geol. Survey, Montpelier, Idaho: Wyoming Geol. Survey, Laramie, Wyo.: (Superseded by C-210).

185. McKelvey, $V_{0} E_{*}$, Smith, L. E., Kinney, D. M., Hudale, $J_{0} W_{0}$, Hosford, G. F., Sears, R, S., Sprouse, D. P., and Stewart, M, D. , Stratigraphic sections of the Phosphoria formation in Utah, 1947 48 : Aug, 15, 1951: U; W; SL; IM; B; Geol. Survey, Montpelier, Idaho; Wyoming Geol. Survey, Laramie, Wyo. (Superseded by Cw211). 
186. Swanson, $R_{0} W_{0}$, Klepper, $M_{0} R_{0}$, LowelI, $W_{0} R_{0}$, Honkala, F. S., Cressman, E. R., Bostwick, D. A., Payne, O. A, and Ruppel, E。 T., Stratigraphic sections of the Phosphoria formation in Montana, 1947 48: Aug. 15, 1951: U; $W_{;}$SL; $I M_{9}$ B; Ceol. Survey, Montpelier, Idaho: Wyoming Geol. Survey, Laramie, Wyo. (Superseded by $\mathrm{C}-209$ and $(-260)$.

187. McKelvey, V. E., Hoppin, R. A., Armstrong, F. C., Gulbrandsen, R。 A., Smith, I. E., and Campbell, Ro Mo, Stratigraphic sections of the Phosphoria formation in Idaho, 1947 48, Part II: Oct. 4, 1951: $\mathrm{U}_{;} \mathrm{W}_{\text {; }} \mathrm{SI}_{\mathrm{S}} \mathrm{IM} ; \mathrm{B}$; Geol. Survey, Montpelier, Idaho; Wyoming Geol. Survey, Laramie, Wyo. (Superseded by C-301).

188. O'Malley, F. Wo, Davidson, D。 F。, Hoppin, $R_{0} A_{0}$, and Sheldon, R。 P., Stratigraphic sections of the Phosphoria formation in Idaho, 1947=48, Part III: Apr. 25, 1952: W: SL: TM: $\mathrm{B}_{\text {; }}$ Wyoming Geol. Survey, Laramie, Wyo. (Superseded by C-262).

221. West, W. S. and White, M. G., The occurrence of zeunerite at Brooks Mountain, Seward Peninsula, Alaska: Aug. 25, 1952: SF; U. S. Geol. Survey offices in Juneau, Anchorage, Fairbanks, and College, Alaska; Territorial Dept. of Mines Offices in Juneau, College, and Nome, Alaska. (Superseded by C-214).

233. Stugard, Frederick, Jr., Geologic map of parts of Glastonbury and Middle Haddam quadrangle, Conn. (Map only): Nov. 25, 1953: Director's Office, Connecticut Geol, and Natural History Survey, Trinity College, Hartford, Conn。: Geol. Survey, Beltsville, Md.

237. Conant, I. C., Origin of the Chattanooga shale: Det. 7, 1952: W. B. Jones, Alabama Geol. Survey, University, Ala.; A. C. McFarlan, Kentucky Geol. Survey, Lexington, Ky.: W. D, Hardman, Division of Geol., State Office Bldg, Nashville, Tenn.

246. Swanson, R. W., McKelvey, V. E., and Sheldon, R。 P., Progress report on investigations of western phosphate deposits: June 21, 1953: IM; D; SL; W; and Geol. Survey, Montpelier, Idaho。 (Superseded by (-297).

254. Stugaxd, Frederick, Jr., Physical exploration for uranium during 1951 in the Silver Reef district, Washington County, Utah: Jan. 11, 1954: SI; D.

258. Cressman, E. R。, Geology of the Dry Valley quadrangle, Idaho: Aug. 25, 1952: W: SL; IM。

259. Meyers, W. B., Geology and mineral deposfts of the northwest quarter Willis quadrangle and adjacent Brown's Lake area, Beaverhead County, Montana: July 28, 1952: $W_{3}: B_{\text {; }} I_{\text {。 }}$

260. Gulbrandsen, $R_{0} A_{0}$, McLaughlin, $K_{0} P_{0}$, Honkala, F. S., Clabaugh, S. E., and Krauskopf, $K, B_{0}$, Ceologic map and structure sections of the Johnson Creek quadrangle, Caribou County, Idaho: Aug, 25, 1952: W: SL; $I M_{0}$ 
TEI

263. Mclielvey, $V_{0} E_{*}$, Swanson, $R_{*} W_{*}$, and Sheldon, $R . P$. , The Permian phosphorite deposits of western United States: Mar. 30, 1953: D; SL; W.

265. Cathcaxt, J. B., Blade, L. V., Davidson, D. F., and Ketnex, K. B., The geology of the Floxida land-pebble phosphate deposits: Mar: 30, 1953: D; SL; Geol. Survey, Plant City, Florida.

271. McKelvey, V. E., Cathcart; J. B, Altschuler, Z, S, Swanson, R. Wo, and Lutz, $K_{0}$, Domestic phosphate deposits: Mar. 30, 1953: D; SI: W: Geol. Survey, Plant City, Florida. (Superseded by chapter in Soil and fertilizer phosphorus in crop nutrition, v. IV of Agronomy, Academic Press, pp. 347-376, 1953).

279. Shoemakex, E. M, and Luedke, R. G., Map of the uranium region of the Colorado Plateau: Mar. 30, 1953: D; SL: GJ: T: New Mexico Bur. of Mines and Mineral Resources, Socorro, $\mathbb{N}$. M.

282. Becraft, $G_{*}$ E. Meschtex, $D_{*} X_{*}$, and Gross, E. B., Geologic map of the Comet area, Jefferson City quadrangle, Jefferson County, Montana: Det. $8,1952:$ SL; W: B, (Superseded by Co277).

287. Finch, W. I. Geology of the Shinarump No. 1 uranium mine, Seven Mile Canyon area, Grand. County, Utah: Jan. 11, 1954: SL; GJ。

304. Sims, P, K, Drake, A. A, and Moench, R, H, Preliminary geologic and vein maps of part of the Central City district, Gilpin and Clear Creek Counties, Colorado: Jan. 11, 1954: D.

312. Lowe11, W. R., Geologic map and structure sections of the southwest quarter Willis quadrangle, Beaverhead County, Montana: Mar. 30, 1953: W: B: IM: Dept. of Geology, Indiana University, Bloomiagton, Ind.

323. Honkala, F, S., Preliminary report on geology of the phosphate de posits in the Centennial Range, Montanaw Idaho: June 22, $1953: \mathrm{U}$; SI: IM; W: B; Geol. Survey, Montpelier, Idaho; Wyoming Geol. Suxvey, Laramie, Wyo. 


\section{b. Trace Elements Memorandum Reports}

TEM

31. Klepper, $M$. R. Forty $=$ Niner, King Solomon Ridge, and West End claims near Clancy, Jefferson County, Montana: Oct. 19, 1951: SL; T; D.

96. Staff, Wamsutter (Red Desert) area, Wyoming, progress report: Oct. 19, 1951: $S L ; T ; D$.

97. Staff, Colorado Front Range area, progress report: Oct. 19, 1951: SL; T: $D_{0}$

104. Thurston, W. R., Exploration of the Buckhorn mica mine, Larimer County, Colorado: July 12, 1950: $D_{\text {g }}$ State Mine Inspector, 220 State B1dg., Denver, Colo.

105. Thurston, W. R., Exploration of the Hyatt pegmatite, Larimer County, Colorado: Mar, 8, 1951: D; Office of State Commissioner of Mines, State Museum Bldg., Denver, Colo.

106. Thurston, $W, R$, Exploration of the Big Boulder prospect, Larimer County, Colorado: Mar. 8, 1951: D; Office of State Commissioner of Mines, State Museum Bldg., Denver, Colo.

149. Jaffe, E. B。 and Sherwood, A. M, Physical and chemical comparison of moder and fossil tooth and bone material: Oct. 19, 1951: SL; $T_{0}: D_{0}$

183. Page, $L . R_{*}$, Interim report of geologic investigation, Lost Creek schroeckingerite deposits, Sweetwater Counicy, Wyoming: Oct. 19, 1951: $S L_{;}: T_{;} \cdot D_{0}$

205. Fischer, R. P., MacKallor, Jules, and Brown, $C . N_{5}$, Base maps of a part of the Thompsons district, Grand County, Utah: May 26, 1952: D; GJ; SI; U; Library, Denver Federal Centex, Denver, Colo.

212. Wyant, D. G, and Stugard, Frederick, Jr., Indian Creek uranium prospects, Beaver County, Utah: Nov. 30, 1951: SL; D。

214. Stugard, Frederick, Jx., Uranium resources in the Silver Reef (Harrisburg) district, Washington County, Utah: Oct. 8, 1951: SL; D; U.

229. Roberts, $W_{0} A_{6}$ and Gude, $A_{0} J_{*}, 3 r d .$, Uraniumbearing deposits west of Clancy, Jefferson County, Montana: Mar. 14, 1952: W; B; Helena Public Iibrary, Helena, Montana. (Superseded by B-988-F).

235. Wedow, Helmuth, Jr。, White, $M_{0} G_{0}$, and Moxham, $R_{0} M_{0}$, Interim report on an appraisal of the uranium possibilities of Alaska: July 16, 1952: Geol. Survey Offices in Juneau, Anchorage, Palmer, Fairbanks, and College, Alaska: Territorial Dept. of Mines Offices in Juneau, Ketchikan, Anchorage, College, and Nome, Alaska: Bureau of Mines, Anchorage, Alaska. (Superseded by $\mathrm{C}-328$ )* 
TEM

251. Weeks, A. D., Red and gray clay underlying ore-bearing sandstone of the Morrison formation in western Colorado: Oct. 19, 1951: SL; T: D.

252. Fletcher, M. H. and Warner, E. R., A fluorimeter for solutions: Det. 19, 1951: SL; T; D. (Superseded by C-311)*

292. Gude, A. J., 3rd, and Mckeown, F. A., Results of exploration at the Old Leyden coal mine, Jefferson County, Colorado: Mar. 30, 1953: $\mathrm{D} ; \mathrm{GJ}$.

301. Luedke, R. G. and Shoemaker, E. M., Tectonic map of the Colorado Plateau: July 23, 1953: D; SL; GJ; T; Bureau of Mines and Mineral Resources, New Mexico School of Mines, Socorro, N. M, ; Office of the Area Director, Bureau of Indian Affairs, Window Rock, Ariz.

355. West, W. S., Reconnaissance for a uranothorianite-bearing lode in the vicinity of the headwaters of the Peace River, Candle quadrangle, Seward Peninsula, Alaska: Oct. 27, 1952: SF; Ceol. Survey Offices in Juneau, Anchorage, Fairbanks, and College, Alaska; Territorial Dept. of Mines Offices in Juneau, College, Ketchikan, and Nome, Alaska. (Superseded in part by $\mathrm{C}-250$ ).

364. Hackman, R. J., Photogeologic map, Aneth-2 quadrangle, San Juan County, Utah: Aug. 25, 1952: SL; D; GJ.

365. Hackman, R. J., Photogeologic map, Aneth 3 quadrangle, San Juan County, Utah: Aug, 25, 1952: SL; D; GJ.

366. Hackman, R. J., Photogeologic map, Aneth-4 quadrangle, San Juan County, Utah: Aug. 25, 1952: SL; D; GJ.

367. Hackman, R. J., Photogeologic map, Aneth-7 quadrangle, San Juan County, Utah: Aug. 25, 1952: SL; D; GJ.

368. Hackman, R. J., Photogeologic map, Anethw8 quadrangle, San Juan County, Utah: Aug. 25, 1952: SL; D; GJ.

369. Hackman, R. J., Photogeologic map, Bluffol quadrangle, San Juan County, Utah: Aug. 25, 1952: SL; D; GJ.

370. Hackman, R. J., Photogeologic map, Bluff-8 quadrangle, San Juan County, Utah: Aug. 25, 1952: SL; D; GJ.

371. Ray, R. G., Photogeologic map, Bluff-13 quadrangle, San Juan County, Utah: Aug. 25, 1952: SL; D; GJ.

372. Tolbert, G. E., Photogeologic map, Carlisle-l quadrangle, San Juan County, Utah: Aug, 25, 1952: SL; D; GJ.

373. Tolbert, G. E., Photogeologic map, Carlisle-8 quadrangle, San Juan County, Utah: Aug. 25, 1952: SI; D; GJ. 
TEM

374. Tolbert, G. E., Photogeologic map, Carlisle-9 quadrangle, San Juan County, Utah: Aug. 25, 1952: SL: D; GJ.

375. Tolbert, G. E., Photogeologic map, Carlislew 16 quadrangle, San Juan County, Utah: Aug. 25, 1952: SL; D; GJ.

376. Hackman, R. J., Photogeologic map, Elk Ridge-13 quadrangle, San Juan County, Utak: Aug, 25, 1952: SL; D; GJ.

377. Hackman, R. J., Photogeologic map, Elk Ridgew 16 quadrangle, San Juan County, Utah: Aug. 25, 1952: ST: D; GJ.

378. Tolbert, G. E., Photogeologic map, Mt. Peale 5 quadrangle, San Juan County, Utah: Aug. 25, 1952: SL; D; GJ.

379. Tolbert, G. E. Photogeologic map, Mt. Pea.le-6 quadrangle, San Juan County, Utah: Aug。 25, 1952: SL; D; GJ.

379A. Tolbert, $G$. E. and Hackman, R. J, Photogeologic map, Mt. Peale-6 quadrangle, San Juan County, Utah: July 23, 1953: SL; D; GJ.

380. Tolbert, G. E., Photogeologic map, Mt. Peale-ll quadrangle, San Juan County, Utah: Aug. 25, 1952: SL; D; GJ.

380A. Hackman, R. J. and Tolbert, G. E., Photogeologic map, Mt. Peale 11 quadrangle, San Juan County, Utah: Feb, 5, 1953: SI; D; GJ.

381. Tolbert, G. E., Photogeologic map, Mt. Peale-12 quadrangle, San Juan County, Utah: Aug. 25, 1952: SL; D; CJ.

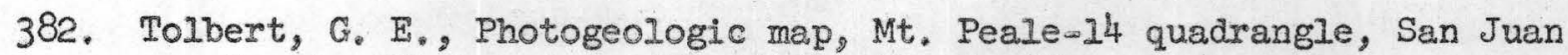
County, Utah: Aug. 25, 1952: SL; D; GJ.

383. Ray, R. G., Photogeologic map, Stinking Spring Creek=11 quadrangle, Emery County, Utah: Aug. 25, 1952: SI; D; GJ.

384. Fischer, W. A, Photogeologic map, Stinking Spring Creekw12 quadrangle, Emexy County, Utah: Aug, 25, 1952: SL; D; GJ.

385. Hackman, R. J., Photogeologic map, Verdure-9 quadrangle, ColoradoUtah: Aug. 25, 1952: SL; D; GJ .

386. Hackman, R. J., Photogeologic map, Verdure - 10 quadrangle, San Juan County, Utah: Aug. 25, 1952: SL; D; GJ.

387. Hackman, R. J., Photogeologic map, Verdure -11 quadrangle, San Juan County, Utah: Aug. 25, 1952: SL; D; GJ.

388. Hackman, R. J., Photogeologic map, Verdure-12 quadrangle, San Juan County, Utah: Aug, 25, 1952: SL; D; GJ.

389. Hackman, R. J., Photogeologic map, Verdure -13 quadrangle, San Juan County, Utah: Aug. 25, 1952: SL; D; GJ. 
TEM

390. Hackman, R. J., Photogeologie map, Verdure--14 quadrangle, San Juan County, Utah: Aug. 25, 1952: SL; D; GJ.

391. Hackman, R. J., Photogeologic map, Verdure-15 quadrangle, San Juan County, Utah: Aug. 25, 1952: SL; D; GJ.

392. Hackman, R. J., Photogeologic map, Verdure-16 quadrangle, Coloradow Utah: Aug, 25, 1952: SL; D; GJ.

393. Hackman, R. J., Photogeologic map, Aneth-5 quadrangle, San Juan County, Utah: Oct. 8, 1952: SL; D; GJ.

394. Bates, C. E. Photogeologic map, Stinking Spring Creek-14 quadrangle, Emexy County, Utah: Oct. 8, 1952: SL; D; GJ.

395. Hackman, R. J., Photogeologic map, Veräure-7-quadrangle, San Juan County, Utah: Oct, 27, 1952: SL; D; GJ.

396. Hackman, R. J., Photogeologic map, Elk Ridge-12 quadrangle, San Juan County, Utah: Oct. 8, 1952: SL; D; GJ.

397. Bates, C. E., Photogeologic map, Stinking Spring Creek-13 quadrangle, Emery County, Utah: Oct. 8, 1952: SI; D; GJ.

398. Tolbert, G. E., Photogeologic map, Mt. Pealewl3 quadrangle, San Juan County, Utah: Oct. 8, 1952: SL; D; GJ.

399. Hackman, R.J., Photogeologic map, Verdure w quadrangle, Coloradow Utah: Oct. 27, 1952: SL; D; GJ.

400. Hackman, R. J., Photogeologic map, Aneth-6 quadrangle, San Juan County, Utah: Oct. 8, 1952: SL; D: GJ.

401. Ray, $R_{0} G$. , Photogeologic map, Bluff 14 quadrangle, Navajo Indian Reservation, San Juan County, Utah: Oct. 27, 1952: SL; D; GJ.

402. Ray, R. G., Photogeologic map, Setsiltso Springs-3 quadrangle, Navajo Indian Reservation, Apache County, Arizona: Oct. 27, 1952: SL; D: GJ: $T$.

403. Hackman, R. J., Photogeologic map, Verdure-8 quadrangle, Coloradow Utah: Oct. 27, 1952: SL; D; GJ.

404. Ray, $R, G$. , Photogeologic map, Setsiltso Springs-4 quadrangle, Navajo Indian Reservation, Apache County, Arizona: Nov. 24, 1952: D; GJ: $T_{*}$

405. Hackman, R. J., Photogeologic map, Verdure 6 quadrangle, San Juan County, Utah: Oct. 27, 1952: D; GJ; SI.

406. Hackman, B. J., Photogeologic map, Verdure -2 quadrangle, San Juan County, Utah: Oct. 27, 1952: D; GJ; SL. 
TEEM

407. Hackman, $R$, Jo, Photogeologic map, Elk Ridge..8 quadrangle, San Juan County, Utah: Oct, $27,1952: \mathrm{SL} ; \mathrm{D} ; \mathrm{GJ}$.

408. Hackman, R. J., Photogeologic map, Verdure-5 quadrangle, San Juan County, Utah: Oct. 8, 1952: SL: D; GJ.

409. Fischer, W. A., Photogeologic map, Clay Hills-13 quadrangle, Navajo Indian Reservation, San Juan County, Utah: Oct. 8, 1952: SL; $D_{\xi} G J$.

410. Hackman, $R$. J., Photogeologic map, Elk Ridge-l quadrangle, San Juan County, Utah: Oct, 27, 1952: SI: D; GJ.

411. Eckstein, W. H., Photogeologic map, Agathla Peak-2 quadrangle, Navajo Indian Reservation, Navajo County, Arizona: Jan, 9, 1953: GJ; $T: D$.

412. Hackman, R. J., Photogeologic map, Agathla Peak-4 quadrangle, Navajo Indian Reservation, Navajo County, Arizona: Oct. 8, 1952: $D_{9}$ GJ: T.

413. Fischer, W. A, Photogeologic map, Clay Hills=12 quadrangle, Piute Indian Reservation, San Juan County, Utah: Oct. 27, 1952: D; $\mathrm{GJ}$; SL.

414. Eckstein, $W_{\text {. }} \mathbb{H}_{0}$, Photogeologic map, Clay Hills 15 quadrangle, Navajo Indian Reservation, San Juan County, Utah: Oct, 27, 1952: D; $\mathrm{GJ}$; SL。

433. Hackmax, R. J., Photogeologic map, Verdure 3 quadrangle, San Juan Couxty, Utah: Oct, 8, 1952: SL: $D_{\text {; }}$ GJ.

438. Hackman, R. J., Photogeologic map, Verdure 4 quadrangle, San Juan County, Utah: Oct. 27, 1952: SL; D: GJ.

439. Ray, R. G., Photogeologic map, Setsiltso Springs-5 quadrangle, Navajo Indian Reservation, Apache County, Arizona: Oct, 27, 1952: D; GJ: T.

440. Ray, $R, G$, Photogeologic map, Agathla Peak-8 quadrangle, Navajo Indian Reservation, Navajo County, Arizona: Nov, 24, 1952: D; GJ: T.

441. Ray, R. G. Photogeologic map, Agathla Peak-1 quadrangle, Navajo Indian Reservation, Nawajo County, Arizona: Jan. 9, 1953: GJ; $D_{j} \mathrm{I}$.

442. Fischer, W. A., Photogeologic map, Clay Hills-14 quadrangle, Navajo Indian Reservation, San Juan County, Utah: Jan. 9, 1953: D: SL.

447. Hackman, R. J., Photogeologic map, Mt. Peale-15 quadrangle, San Juan County, Utah: Feb, 5, 1953: SI; D; GJ. 
TEM

448. Hackman, R. J., Photogeologic map, Mt. Peale-16 quadrangle, UtahColorado: Jan. 9, 1953: D; SL.

449. Bates, C.E. and Eckstein, W. H., Photogeologic map, Clay Hills-16 quadrangle, Navajo Indian Reservation, San Juan County, Utah: Jan. 9, 1953: D; SL.

450. Hackman, R. J., Photogeologic map, Mt. Peale-9 quadrangle, UtahColorado: Jan. 9, 1953: D; SL.

451. Hackman, R. J., Photogeologic map, Mt. Pealew10 quadrangle, San Juan County, Utah: May II, 1953: D; SL; GJ.

452. Hackman, R. J., Photogeologic map, Aneth-I quadrangle, Utah-Colorado; Aug. 25, 1952: D; GJ; SL。

453. Hackman, R. J., Photogeologic map, Elk Ridge-9 quadrangle, San Juan County, Utah: Aug. 25, 1952: D; GJ; SL.

465. Hackman, R. J., Photogeologic map, Mt. Peale-8 quadrangle, UtahColorado: Jan. 9, 1953: D; SL.

466. Hackman, R. J., Photogeologic map, Mt. Peale-7 quadrangle, San Juan County, Utah: Feb. 5, 1953: SL; D; GJ.

467. Hackman, R. J., Photogeologic map, Mt. Peale-l quadrangle, Grand and San Juan Counties, Utah, Montrose County, Colorado: Feb. 5, 1953: SL; D; GJ.

468. Ray, R. G., Photogeologic map, Agathla Peak-7 quadrangle, Navajo Indian Reservation, Navajo County, Arizona: Feb. 5, 1953: D; GJ; SL; T.

469. Fischer, W. A, and Condon, W. H., Photogeologic map, Navajo Mountain -9 quadrangle, Navajo Indian Reservation, San Juan County, Utah: Feb. 5, 1953: SL; GJ; D.

470. Fischer, W. A. and Condon, W. H., Photogeologic map, Navajo Mountain-16 quadrangle, San Juan County, Utah: Feb. 5, 1953: SL; GJ; D.

499. Fischer, W. A, and Condon, W. H. Photogeologic map, Shanto Spring I quadrangle, Navajo Indian Reservation, Navajo County, Arizona: Feb. 5, 1953: SL; GJ; D; T.

500. Ray, R. Go, Photogeologic map, Orange Cliffs -13 quadrangle, Gariield County, Utah: Feb. 5, 1953: D; GJ; SL.

501. Ray, R. G., Photogeologic map, Orange Cliffs-14 quadrangle, Gariield County, Utah: Feb. 5, 1953: D; GJ; SL。 
TEM

508. Stead, F。 W., Bals ley, J. R, Moxham, R. M, and Reinhardt, P. W., Airborne radioactivity survey of the Pumpkin Buttes area,

Campbe11 and Johnson Counties, Wyoming: June 10, 1953: D; GJ; $\mathrm{SF}_{\mathrm{P}} \mathrm{SL}$ : Ceol. Survey Offices at Caspex, Wyo. and Custer, S, D.; University of Wyoming, Laramie, Wyo; Bureau of Mines Office, Rapid City, $S$. $D_{5}$; $\mathrm{MI}_{\text {}} \mathrm{DA}_{\text {j }} \mathrm{SIA}$; $\mathrm{BA}$; GJA; H; $\mathrm{R}$.

523. Ray, $R$. Go, Photogeologic map, Oxange Cliffs 21 quadrangle, Wayne and Carfield Counties, Utah: May 11, 1953: $\mathrm{D}$; SI; GJ.

524. Ray, $R$. G. Photogeologie max, Orange Cliffs-12 quadrangle, Wayne and Garfield Counties, Utah: July 23, 1953: D; SL; GJ.

525. Hosley, V. M, Photogeologic map, Orange Cliffs $=5$ quadrangle, Wayne County, Utah: JuIy 23, 1953: D; SL; CJ,

526. Hackman, R.J., Photogeologic map, Navajo Mountain-13 quadrangle, Navajo Indian Reservation, San Juan and Kare Counties, Utah: May 11, 1953: $D_{9}^{\circ} G_{3}: S I_{0}$

527. Hackman, $R$, Jo, Photogeologic map, Mt. Peale 4 quadrangle, Grand and San Juax Counties, Utrah: July 23, 1953: $D_{i}$ CJ: SL.

528. Oxkild, P. F., Photogeologic map, Stinking Spring Creek 5 quadrangle, Emery County, Utak: May 11, 1953: D; GJ; SL.

529. Scott, J. M. Photogeologic map, Circle Cliffs -9 quadrangle, Garfield County, Utah: June 22, 1953: $D_{\xi} \mathrm{GJ}_{5} \mathrm{SL}$.

530. Hemphi11, W. R., Photogeologic map, Stinking Spring Creek 6 quadrangle, Emery Courty, Utah: June 22, 1953: $\mathrm{D}_{3} \mathrm{SL}: \mathrm{GJ}$.

531. Hackman, R.J., Photogeologic map, Circle Cliffs-10 quadrangle, Garfield County, Utah: May 11, 1953: $\mathrm{D} ; \mathrm{GJ}$ : SL。

532. Orkild, P. P., Photogeologic map, Stinking Spring Creek-4 quadrangle, Emery County, Utah: May 11, 1953: D; GJ; SL.

536. Witinind, I. J., and others, Preliminary report on geologic studies in the Monument Valley area, Axlzona ( 3 maps only -- Agathla Peak, (Garnet Ridge, and Boot Mesa): May 11, 1953: $\mathrm{D} ; \mathrm{SL}$; GJ; $\mathrm{T}$.

541. Eckstein, W. H., Photogeologic map, Agathla Peak 6 quadrangle, Nava,jo Indian Reservation, Navajo County, Arizona: June 22, 1953: $\mathrm{D}$; $\mathrm{GJ}$; $\mathrm{SL}$; $\mathrm{I}$ 。

542. Orkild, P. P., Photogeologic map, Stinking Spring Creek-3 quadrangle, Emexy County, Utah: June 22, 1953: $\mathrm{D}_{9} \mathrm{SL}$; GJ.

544. Hosley, V. M., Photogeologic map, Carlis le-5 quadrangle, Wayne and San Juan Counties, Utah: July 23, 1953: $D_{\text {; }}$ SI; GT. 
TEM

545. Orkild, $P_{0}$ P, Photogeologic map, Stinking Spring Creek-15 quad. rangle, Emery County, Utah: July 23, 1953: D; SL; GJ.

546. Condon, W. H., Photogeologic map, Emeryol6 quadrangle, Emery County, Utah: July 23, 1953: D; GJ; SL。

547. Hosley, V. M. Photogeologic map, Carlisle 4 quadrangle, Wayne and San Juan Counties, Utah: JuIy 23, 1953: D; GJ; SI.

548. Hackman, $R$ 。 J, Photogeologic map, Circle Cliffs-2 quadrangle, Garfield County, Utah: Dec, 21, 1953: D; GJ; SL。

549. Scott, J.M., Photogeologic map, Circle Cliffs-3 quadrangle, Gar field County, Utah: July 23, 1953: $D$; GJ; SL.

550. Hemphil1, $W_{0} R_{0}$, Photogeologic map, Stinking Spring Creek 7 quadm rangle, Emexy County, Utah: June 22, 1953: D; SL; GJ.

584. Hosley, V. M., Photogeologic map, Moab-14 quadrangle, Grand County, Utah: JuIy 23, 1953: D; GJ; SI.

585. Hackman, R. Jo, Photogeologic map, Circle Cliffs 6 quadrangle, Garfield County, Utah: JuIy 23, 1953: D: GJ; SI.

586. Scott, J.M. Photogeologic map, Circle Cliffs 1 quadrangle, Garfield County, Utah: Aug. 17, 1953: $\mathrm{D}$; GJ; SI.

587. Bates, C.E。, Photogeologic map, Carlis le.6 quadrangle, San Juan County, Utah: Oct. 19, 1953: D: SL: GJ。

588. Condon, W. H., Photogeologic map, Emery 9 quadrangle, Emery County, Utah: Oct. $19,1953:$ D; SL: GJ.

589. Hemphil1, W。 R. Photogeologic map, Stinking Spring Creek-2 quadrangle, Emery County, Utah: July 23, 1953: D; SL; GJ。

590. Hackman, R. J., Photogeologic map, Circle Cliffs-7 quadrangle, Garw field County, Utah: Aug. 17, 1953: D; GJ; SL。

591. Orkild, P. P., Photogeologic map, Emery I quadrangle, Emexy County, Utah: Aug. 17, 1953: D; SL; GJ.

592. Bates, C. E. Photogeologic map, Carlisle-3 quadrangle, San Juan County, Utah: July 23, 1953: D; GJ; SL.

593. Condon, W. H., Photogeologic map, Emery 8 quadrangle, Emery County, Utah: Aug. 17, 1953: D; GJ; SL。

594. Orkild, P. P. Photogeologic map, Orange Cliffs-3 quadrangle, Wayne County, Utah: July 23, 1953: D; GJ; SL. 
TEM

595. Scott, J. M. Photogeologic map, Circle Cliffs $=8$ quadrangle, Garfield County, Utah: JuIy 23, 1953: D: SL: GJ。

596. Hackman, R. J., Photogeologic map, Mt. Pennell-5 quadrangle, Garfield County, Utah: Aug. 17, 1953: D; GJ; SL.

597. Scott, J. M., Photogeologic map, Mt. Penne11-12 quadrangle, Garfield County, Utah: July 23, 1953: $D_{;}$GJ; SL.

598. Hosley, V. M, Photogeologic map, Moab-15 quadrangle, Grand County, Utah: Aug, 17, 1953: D: GJ: SL.

600. Orkild, P. P., Photogeologic map, Orange Cliffs -2 quadrangle, Wayne County, Utah: Aug. 17, 1953: D; GJ; SI.

602. Mackin, J. H. and Schmidt, D, I., Reconnaissance geology of placer deposits containing radioactive minerals in the Bear Valley district, Valley County, Idaho (Part I): June 22, 1953: SL; W: IB.

605. Henderson, J, R。 and Moxham, R. M, Airborne radioactivity survey of the Devil's Tower area, Crook County, Wyoming: June 1, 1953: D: GJ: SF; Geol. Survey Offices at Custer, S. D., Casper, and Sheridan, Wyo., Science Ha11, University of Wyoming, Laramie, Wyo.; NY; $D A$; $\mathrm{H}$; GJA; SLA; BA; R.

606. Meuschire, J. I. and Moxham, R. M., Airborne radioactivity survey of the Miller Hill area, Caxbon County, Wyoming: Mar, 28, 1953: D; GJ; SF; SL; Geol. Survey Offices at Custer, S. D, Casper and Sheridan, Wyo., University of Wyoming, Laramie, Wyo. : $\mathrm{NY}$; $\mathrm{DA}$; $\mathrm{H}_{\text {; }}$ GJA; SLA; BA; $R$, ?

607. Johnson, $R, W$, and Moxham, R. M, Airborne radioactivity survey of portions of the Defiance Uplift and Carrizo Mountains, Apache County, Arizona: Aug. 25, 1953: D; GJ; SF; SL; T; Geol. Survey Offices at Spencer Bldg., Room 5, Flagstaff, Ariz:, Holbrook, Ariz., Hadley Hall, University of New Mexico, Albuquerque, N.M., Public Inquiries Office, Room 529 Post Office and Court House Bldg., Los Angeles, Calif.: Bureau of Mines Office, Rapid City, $\mathrm{S} . \mathrm{D}$; $\mathrm{NY} ; \mathrm{DA} ; \mathrm{GJA}$; $\mathrm{H}_{;} \mathrm{SLA} ; \mathrm{BA} ; \mathrm{R}$.

609. Meuschire, J. L. and Moxham, R. M., Airborne radioactivity survey of the Aspen Mountain area, Sweetwater County, Wyoming: Aug. 10, 1953: $\mathrm{D}$; GJ; SF; SL; Geol. Survey Offices at Custer, S. D., Sheridan and Casper, Wyo, University of Wyoming, Laramie, Wyo.; Bureau of Mines, Rapid City, $S_{*}$ D.; NY; DA: GJA; H; SLA; T; $B A$. 
TEM

610. Meuschke, $J, I$, and Moxham, $R, M_{0}$, Airborne radioactivity survey of the Tabernacle Buttes area, Sublette and Fremont Counties, Wyoming: Aug. 10, 1953: D; GJ; SF; SL; Geol. Survey Offices at Custer, $S_{8} D_{0}$, Sheridan and Casper, Wyo., University of Wyoming, Laramie, Wyo.; Bureau of Mines, Rapid City, $S, D_{0}$; NY; $\mathrm{DA} ; \mathrm{GJA} ; \mathrm{H} ; \mathrm{SLA} ; \mathrm{BA} ; \mathrm{B}$.

611. Meuschke, J. I. and Moxham, R, M., Airborne radioactivity survey of the West Lone Tree area, Uinta County, Wyoming: Aug. 10, 1953: D; GJ; SF: SL; Geol. Survey Offices at Custer, S. Do, Sheridan and Casper, Wyo., University of Wyoming, Laramie, Wyo; Bureau of Mines, Rapid City, S. Do: NY; DA; GJA; H; SLA; BA; R. . .

612. Hemphill, W。 R。, Photogeologic map, Orange Cliffs 07 quadrangle, Wayne County, Utah: Sept. 16, 1953: $D_{2}$ GJ: SI.

613. Hackman, R. J., Photogeologic map, Mt。 Pennell-14 quadrangle, Garfield and Kane Counties, Utah: Oct. 19, 1953: D; GJ; SL.

614. Hackman, R。 J., Photogeologic map, Circle Cliffs-16 quadrangle, Garfield and Kane Counties, Utah: Sept, 16, 1953: D; GJ; SL.

615. Scott, J.M. Photogeologic map, Mt。 Pennell-13 quadrangle, Garfield and Kane Counties, Utah: Sept。16, 1953: $\mathrm{D} ; \mathrm{GJ}$ : SL.

616. Bates, C. E., Photogeologic map, Moab-10 quadrangle, Grand County, Utah: Sept. 16, 1953: D; GJ; SL.

617. Orkild, PoPo, Photogeologic map, Tidwell-16 quadrangle, Emery and Grand Counties, Utah: Dec. 21, 1953: $D_{;}$GJ: SL。

618. Condon, W. H., Photogeclogic map, Orange Cliffs-10 quadrangle, Wayne and Garfield Counties, Utah: Sept. 16, 1953: D: SL; GJ。

619. Scott, J. Mo, Photogeologic map, Navajo Mountain 4 quadrangle, Kane County, Utah: Oct. 19, 1953: D; GJ SL.

620. Scott, J. Mo Photogeologic map, Navajo Mountain 6 quadrangle, San Juan and Kane Counties, Utah: Dec。21, 1953: D; GJ; SL.

621. Hackman, R.J., Photogeologic map, Navajo Mountain-3 quadrangle, Kane and San Juan Counties, Utah: Oct, 19, 1953: D; GJ; SL.

633. Scott, J. M, Photogeologic map, Mt. Pennell-1I quadrangle, Garfield County, Utah: Oct。 19, 1953: D; GJ: SL。

634. Scott, J. M., Photogeologic map, Circle Cliffs 4 quadrangle, Garfield County, Utah: Dec。21, 1953: D; GJ; SL。

635. Scott, Jo M。, Photogeologic map, Circle Cliffs 5 quadrangle, Garfield County, Utah: Oct. 19, 1953: D; GJ; SI. 
TEM

636. Hackman, $R_{0} J$, Photogeologic map, Circle Cliffs-11 quadrangle, Carfield County, Utah: Oct. 19, 1953: $\mathrm{D}_{2} \mathrm{SL} ; \mathrm{GJ}$.

637. Hackman, R. J., Photogeologic map, Circle Cliffs-14 quadrangle, Carfield and Kane Counties, Utah: Oct. 19, 1953: $D_{3}$ SL; GJ.

638. Hosley, V. M. Photogeologic map, Straight Cliffs-1 quadrangle, Kane County, Utah: Oct. 19, 1953: $\mathrm{D}_{\xi} \mathrm{SI} ; \mathrm{GJ}$

639. Hosley, $V . M_{*}$, Photogeologic map, Moab-12 quadrangle, Grand County, Utah: Oct. 19, 1953: $D_{2}$ GJ $S I$.

640. Hackman, $R_{0} J_{0}$ and Tolbert, $G_{0} E_{0}$, Photogeologic map, Notom=15 quadrangle, Garield County, Utah: Nov, 25, 1953: D: SL: GJ.

64. Hackman, R.J., Photogeologic map, Circle Cliffs 15 quadrangle, Garfield and Kane Counties, Vtah: Oct, 19, 1953: $D_{3}$ ST: GJ.

642. Orkild, P. P, Photogeologic map, Tidwell-5 quadrangle, Emery County, Utah: Nov, 25, 1953: $D$; GJ: SL。

644. Moxham, R。 Mo and Johnson, R. Wo, Airborne radioactivity survey of parts of the Atlantic Ocean Beach, Virginia to Florida: Sept. 18, 1953: $D_{\text {; }} \mathrm{GJ}$; SF; SL; Geol. Survey Offices at Plant City, Fla., and New Dining Hall, Floxida State University, Tallahassee, Fla.; Florida Geol. Survey, Tallahassee, Fla.: Georgia Dept. of Mines, Mining and Ceology, 425 State Capitol, Atlanta, Ga.; Bureau of

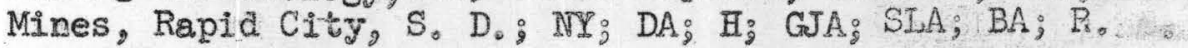

650. Hemphil1, W. R, Photogeologic map, Stinking Spring Creek-9 quadrangle, Emery County, Utah: Nov, 25, 1953: $\mathrm{D} ; \mathrm{SL}$; $\mathrm{CJ}$.

651. Kent, B. H., Photogeologic map, Desert Lake=14 quadrangle, Emery County, Utah: Nor, 25, 1953: $\mathrm{D}$; SL: GJ.

652. Bates, C. E., Photogeologic map, Moab-11 quadrangle, Grand County, Utah: Dec. 21, 1953: $D_{9}$ GJ; SL.

654. Hemphil1, W。 R., Photogeologic map, Orange Cllffs -8 quadrangle, Wayne and San Juan Counties, Utah: Nov, 25, 1953: D: GJ: SL。

655. Orkild, P. P., Photogeologic map, Tidwell-4 quadrangle, Emery County, Utah: Dec。21, 1953: $D_{3}$ GJ; SL.

656. Hosley, V. M., Photogeologic map, Tidwell-15 quadrangle, Emery County, Utah: Nov. 25, 1953: $\mathrm{D}_{\text {: }} \mathrm{CJ}$ : SI.

657. Hemphill, $W$, R。, Photogeologic map, Stinking Spring Creek-8 quadrangle, Emery County, Utah: Dec。2I, 1953: $\mathrm{D}_{3} \mathrm{GJ}$ : SL。

658. Kent, B. H., Photogeologic map, Desert Lake=11 quadrangle, Emexy County, Utah: Nov. 25, 1953: $\mathrm{D}_{3} \mathrm{GJ}$ : SL。 
TEM

659. Oxkild, P. P., Photogeologic map, Woodside-13 quadrangle, Emery County, Utah: Nov. 25, 1953: D; SL; GJ.

660. Bates, C. E. and Hosley, V. M., Photogeologic mep, Tidwell-9 quad. rangle, Emery and Grand Counties, Utah: Nov, 25, 1953: D; GJ: SL:

661. Scott, J. Mo, Photogeologic map, Kaiparowits Peak 8 quadrangle, Garfield County, Utah: Jan. 11, 1954: D; SL; GJ.

662. Scott, J. $M_{*}$, Photogeologic map, Straight Cliffsw2 quadrangle, Kane County, Utah: Jan. 11, 1954: D; SL; GJ.

663. Scott, J. M. Photogeologic map, Kaiparowits Peak-9 quadrangle, Garfield County, Utah: Dec. 21, 1953: D; GJ; SL.

664. Condon, $W_{0} H_{*}$, Photogeologic map, Orange Cliffsw quadrangle, Wayne County, Utah: Nov. 25, 1953: D; GJ; SL.

665. Orkild, P. P., Photogeologic map, Orange Cliffs 1 quadrangle, Wayne and San Juan Counties, Utah: Nov. 25, 1953: D; GJ; SI.

672. Cathcart, J. B. and Ward, E. I. M., Ownership maps of parts of Hillsborough and Polk Counties, land-pebble phosphate district, Florida: Dec, 2l, 1953: Geol. Survey, Plant City, Fla。; Florida Geol. Survey, Tallahassee, Fla. 


\section{c. Miscellaneous}

a. Cheney, T. M., Peterson, J. A., Sheldon, R. P., Smart, R. A., Waring, R. G., and Warner, M. A., Stratigraphic sections of the Phos = phoria formation measured and sampled in 1951: Oct. 8, 1952: W: SL; IM; B; Wyoming Geol, Survey, Laramie, Wyo.

b. Cheney, T. M, Sheldon, R。 P., Cressman, E. R, Smart, R. A, , and Carswell, I. D., Stratigraphic sections of the Phosphoria formation measured and sampled in 1952: June 1, 1953: SI; $\mathrm{W}_{3}$ IM; $\mathrm{B} ; \mathrm{U}_{3}$ Geol. Survey, Montpelier, Idaho; Wyoming Geol. Survey, Laramie, Wyo.

c. Grimaldi, F. S., Quercetin as a colorimetric reagent for zirconium: Oct. 19, 1953.

d. Kennedy, G. C., Preliminary report on the geology of a portion of the SE 1/4 Lyon quadrangle, Montana-Idaho: Jvne 14, 1949: W; IM; B.

e. Lowell, W. R, , Geology of the Small Horn Canyon, Daly's Spur, Cedar Creek and Dell areas, southwestern Montana: Dec。 8, 1949: B; W.

f. Luedke, Ro G., Stratigraphy and structure of the Miners Mountain area, Wayne County, Utah: Aug. 17, 1953: SI.

g. McKelvey, V. E., Preliminary report on the stratigraphy of the phosphatic shale member of the Phosphoria formation in western Wyoming, southeastern Idaho and northeastern Montana: Feb. 1947.

h. Olson, J.C., Geologic setting of the Mountain Pass rare earth deposits, San Bernardino County, California: Oct, 27, 1952: SF; California Div. of Mines and Geology, Ferry Bldg, San Francisco, Calif.

i. Olson, Jo Co, Preliminary report on the Dawley Canyon beryl deposits, Ruby Mountains, Elko County, Nevada: Oct. 14, 1949: Nevada Bureau of Mines, Reno, Nev.

3. Olson, J. C., Preliminary report to accompany geologic map of the Mountain Pass District, San Bernardino County, California: Mar. 14, 1952: SL: D。

k. Sharp, W. N. and Olson, J. C., Geologic map of the baritic carbonate body near Mountain Pass, San Bernardino County, California: June 26, 1951: $D_{\text {; }}$ SF; California Div, of Mines, Ferry Bldg., , San Francisco, Calif.: Library, Dept. of Ceology, California Institute of Technology, Pasadena, Calif.

m. Sheldon, R. $P_{0}$, Cressman, E. R., Smart, R. A, Waring, R, G., Thompson, M. E., Weiser, J. D., Jones, R. J., and Peirce, H. W., Stratigraphic sections of the Phosphoria formation measured and sampled in 1949: Dec. 27, 2951: W: SI; IM; B; U; Geol. Survey Information Office, Montpeliex, Idaho; Wyoming Geol. Survey, Laramie, Wyo. 
n. Shomakex, E. Mo, Preliminary geologic map of part of the Sinbad Valleywischer Valley anticline, Colorado and Utah; Structure map and sections of the Sinbad Valley-Fischer Valley anticline, Colorado and Utah: Aug. 25, 1952: SL; D.

o. Swanson, R. W., Geology of a part of the Virginia City and Eldridge quadrangles, Montana: Mar. 8, 1951: W; B; Geol. Library, Princeton University, Frinceton, N. J.; Geol. Library, University of Minnesota, Minneapolis, Minn.

p. Swanson, R. Wo, Waring, R. G., Peirce, H. W., Warner, M. A. , and Smart, R. A. Stratigraphic sections of the Phosphoria formation measured and sampled in 1950: Dec. 27, 1951: W; SL; IM; B; U; Geol. Survey Information Office, Montpelier, Idaho; Wyoming Geol. Survey, Laramie, Wyo. 
2. TRACE ELEMENTS REPORTS ISSUED BY THE U。S。ATOMIC ENERGY COMMISSION, TECHNICAI INFORMATION SERVICE, OAK RIDGE, TENN。

Trace Elements reports that have been issued by Technical Information Service (referred to as TIS), are Iisted by Trace Elements Investigations and Trace Elements Memorandum Report numbers. The asterisk indicates that the report has not yet been released by TIS, or published。 If TIS issued a Trace Elements Report under a different number, the TIS number is given after the title (i。e, TEI-23 was issued as AECD-1815 - Atomic Energy Commission Declassified; TEM-444 was issued as TEM-444-A)。The year listed is the date shown on the copy of the TIS issue.

These reports are on file at the U. S. Geological Survey Library, Room 1033, GSA Building, Washington 25, D。C., and at the following AEC depository libraries:

\section{CALIFORNIA}

Berkeley, University of California General Library COLORADO

Denver, Denver Public Iibrary CONNECTICUT

New Haven, Yale University Library

DISTRICT OF COLUMBIA GEORGIA

Washington, Library of Congress ILLINOIS

Atlanta, Georgia Institute of Technology Library

Chicago, John Crerar Library

Chicago, University of Chicago Library INDTANA

Urbana, University of IIlinois Library

IOWA

Iafayette, Purdue University Library KENTUCKY

Ames, Iowa State College Library

Lexington, University of Kentucky Library LOUISIANA

Baton Rouge, Louisiana State University Library 
MASSACHUSETTS

Cambridge, Harvard University Library

Cambridge, Massachusetts Institute of Technology Library MICHIGAN

Ann Arbor, Unjversity of Michigan Iibrary MINNESOTA

Detroit, Detroit Public Library

MISSOURI

Kansas City, Linda Hall Library

NEW JERSEY

St. Louis, Washington University Library

Princeton, Princeton University Library

NEW MEXICO

Albuquerque, University of New Mexico

NEW YORK

Buffalo, Rockwood Memorial Library

Ithaca, Cornell University Library

New York, Columbia University Library

New York, New York Public Library

Troy, Rensselaex Polytechnic Institute

NORTH CAROLINA

Durham, Duke University Library

OHIO

Raleigh, North Carolina State College Library

Cincinnati, University of Cincinnati Library

Cleveland, Cleveland Public Library

OKI.AHOMA

Columbus, Ohio State University Library OREGON

Stillwater, Oklahoma Agricultural and Mechanical College Library PENNSYLVANIA

Philadelphia, University of Pennsylvania Library TENNESSEE

Pittsburgh, Carnegie Library of Pittsburgh

TEXAS

Knoxville, University of Tennessee Library

Nashville, Joint University Libraries

UTAH

Austin, University of Texas Library

WASHINGTON

Salt Lake City, University of Utah Library

WISCONSIN

Seattle, University of Washington Library

Madison, University of Wisconsin Library 
a. Trace Elements Investigations Reports

TEI

23. Grimaldi, F, S., Elimination of interference by nickel in the determination of uranium by means of zinc amalgam reductors: 1946; AECD-1815. (Superseded by Pt. 5 in B-1006)*

28. Schlecht, W. G., Control chart method applied to errors in radioactive counting: $1946 ; \mathrm{MDDC}-695$.

29. Fleischer, Michrel and Cameron, E. N, Geochemistry of beryllium: 1946; $\mathrm{MDDC}=643$.

31A. Foster, $M_{0} D_{0}$, Stevens, $R_{0} E_{0}$, Grimaldi, F, S., Schlecht, W. G, and Fleischer, Michael, Methods for the complete decomposition of rock and oxe samples to be analyzed for very small amounts of uranium. and thorium: 1946; AECD-1782. (Superseded by Pt. 2 in B-1006)*

31B. Foster, $M_{0} D_{0}$ and Stevens, $R_{0} E_{\text {, }}$, The determination of very small amounts of uranium in naturaliy occurring materials: 1946: AECD-2630. (Superseded by Pt. 4 in B-1006).*

31C. Grimaldi, F. So, The determination of very small amounts of uranium in rocks and minerels: 1946: $\mathrm{AECD}-2631$. (Superseded by Pt. 3 in $\mathrm{B}=1006)^{*}$.

31D. Fahey, J. Jo axd Foster, M. Do, The determination of small amounts of thorium in rocks and minerals: 1946; AECD-2629. (Superseded by Pt. 19 in $\mathrm{B}=1006 \%$

31E. Grimaldi, F, $S_{0}$ and Fairchild, $J_{0} G_{0}$, The determination of very small amounts of thorium in naturally occurring materials: 1946 ; AECD 2632. (Superseded by Pt. 18 in B-1006) *

31H. Fleischer, Michael and Harder, Jo 0., Geochemistry of Indium: 1946; MDDC $=646$.

31I. Fleischer, Michael and Harder, J. O, Geochemistry of germanium: 1946; MDDC 645.

31J. Fleischer, Michael and Harder, J. $\mathrm{O}_{0}$, Geochemistry of columbium and tantalum: 1946 : MDDC- 644 .

44. Grimaldi, F. S. and Marsh, C. A., The determination of thorium in high grade and 1ow grade ores: 1947: AECD-2818. (Superseded by Pt. 20 in $\mathrm{B}-1006)$ *

47. Grimaldi, F。 S, and Levine, Harry, The rapid fluorimetric determination of uranium in low grade ores, a preliminary report: 1948: AECD2824. (Superseded by Pt. 6 in Bw1006)* 
TEI

65. Nelson, J. M., Prospecting for uranium with car-mounted equipment, a progress report: 1949. (Superseded by B $-988-I$ ).

67. Mckeown, F.A., Reconnaissance of radioactive rocks of Vermont, New Hampshire, Connecticut, Rhode Island, and southeastern New York: 1951.

68. Nelson, J.M. and Naxten, P. F., Reconnaissance of radioactive rocks of Maine: 1951.

69. Johnson, D. H., Reconnaissance of radioactive rocks of Massachusetts: 1951.

70. Narten, P. F. and McKeown, F. A., Reconnaissance of radioactive rocks of the Hudson Valley and Adirondack Mountains, New York: 1952.

98. Grimaldi, F. S., Ward, F. No, and Kreher, Ruth, A direct quantitative fluorimetric method for the determination of small amounts of uranium in the field and laboratory: 1949; AECD-2825. (Super seded by Pt。 9 in $B-1006)$.*

105. Levine, Harry and Grimaldi, F. S., Application of mesityl oxide to the determination of thorium: 1950; AECD-3186. (Superseded by Pt. 21 in $B=1006) *$

118. Silverman, S. R., Fuyat, R. K., and Weiser, J. D., The quantitative determination of calcite associated with carbonate-bearing apatites: 1951. (Superseded by Am. Mineralogist, v. 37, nos. 3-4, pp. 211222, 1952).

120. Fletcher, M. H. and May, Irving, An improved fluorimeter for the determination of uranium in fluoride melts: 1950. (Superseded by Pt. 10 in $B=1006)$ *

129. Stern, T. W. A catalog of study material of radioactive minerals: 1950.

130. Fletcher, M. H., A study of critical factors in the "direct" fluorimetric determination of uranium (and addendum): 1950. (Super seded by Pt. 8 in $B-1006) *$

133. Fletcher, Mo H., May, Irving, and Anderson, J. W., The design of the Model V transmission fluorimeter: 1950. (Superseded by Pt. 12 in $\mathrm{B}=1006)$ *

140. Trites, A. F., Jr., and Tooker, E. W., Uranium and thorium deposits in east-central Idaho and southwestern Montana: 1952; TEI-140, Pt. 1. (Superseded by $\mathrm{B}-988 \mathrm{~m}$ H).

142. Thompson, M. E., Distribution of uranium in rich phosphate beds of the Phosphoria formation: 1951. (Superseded by B $=988-D$ ). 
TEI

143. Waring, C. I. and Anne1I, C. S, A semiquantitative spectrographic method for the analysis of minerals, rocks, and ores: 1951. (With TEI-215- Anal. Chemistry, v。25, no. 8, pp.1174-79, 1953).

144. Phair, George and Onoda, Kiyoko, Hydrothermal uranothorite in fluorite breccias from the Blue Jay mine, Jamestown, Boulder County, Colorado: 1951. (Superseded by Am. Mineralogist, v. 37, nos. 7-8, pp. 659-666, 1952).

148A. Rabbitt, J.C., Summary of the research work of the Trace Elements Section, Geochemistry and Petrology Branch, for the period April 1 , 1948 - December 31, 1950: 1951.

151. Rabbitt, J. C., Summary of the research work of the Trace Elements Section, Geochemistry and Petrology Branch, for the period January 1-march 32, 1951: 1951.

152. Cuttitta, Frank, A photometric method for the estimation of the oil yield of oil shale: 1951. (Superseded by chapter in B-992).

153A. Guttag, N.S. and Grimaldi, F. S., Fluorimetric determination of uranium ir shales, lignites, and monarites after alkali carbonate separation: 1951. (Superseded by Pt. 15 in B-1006)*

179. Myers, A. T. and Barnett, P. R, Contamination of rock samples during griming as determined spectrographically: 1952. (Superseded by Am. Joux. Sci., v. 251, pp. 814-830, Nov., 1953).

180. Craig, L. C., Holmes, C.N., Cadigan, R. A., Freeman, V. I., Mullens, T. E., and Weir, $G$. W., Preliminary report on the stratigraphy of the Morrison and related formations of the Colorado Plateau region: 1951. (To be part of B-1009).*

181. Pietsch, Audrey and Grimaldi, F. S., The fluorimetric determination of uranium in nonsaline and saline waters: 1952. (Superseded by Pt. 17 in $B \times 1006)$ *

182. Rabbitt, J. C., Summary of the research work of the Trace Elements Section, Geochemistry and Petrology Branch, for the period July I w September 30, 1951: 1952.

203. Smith, J.F., Jro, Hinrichs, E. N., and Luedke, R,G., Progress report on geologic studies in the Capital Reef area, Wayne County, Utah: 1952.

206. Rabbitt, J. C., Rubey, W. Wo, Butier, A. P., Jx。, Lovering, T. S。, and McKelvey, V. E。, A preliminary outline of desirable research in the geochemistry of uranium: 1949.

207. Butler, A. P., Jro, The Geological Survey's work on the geology of uranium and thorium deposits: 1952. 
TEI

208. McKelvey, V. E., Trace elements work of the Geological Survey: 1951.

209. Cannon, R. S., Jx。, Geological Survey's work on isotope geology of uranium and thorium and their decay products: 1952.

210. Cuttitta, Frank, A volumetric method for the estimation of the oil yield of oil shale: 1952. (Superseded by chapter in B-992).

211. Stead, F.W., The Geological Survey's work on development of pros pecting tools, instruments, and techniques: 1952.

212. Cathcart, J. B. and Davidson, D. F., Distribution and origin of phosw phate in the landopebble district of Florida: 1952.

213. Gordon, E. D., Withington, C. F., and Dow, V. To, Practices and results obtained with sample collectors for wagon-drill cuttings: 1953.

215. Waring, C. I. and Anne11, C. S., A semiquantitative spectrographic method for the analysis of minerals, rocks, and ores (II): 1952. (With TEI-143 an Anal. Chemistry, v. 25, no. 8, pp.1174-9, 1953).

216. Waring, C. I. and Worthing, Helen, A spectrographic method for determining trace amounts of lead in zircon and other minerals: 1952. (Superseded by Am. Mineralogist, v. 38, nos.9-10, pp.827-33, 1953).

218. Rabbitt, J.C., Summary of the research work of the Trace Ilements Section, Geochemistry and Petrology Branch, for the period Octow ber 1-owecember 31, 1951: 1952.

223. Cuttitta, Frank, The colorimetric determination of total iron with Ow phenanthroline: a spectrophotometric study: 1953.

236. Milkey, R. G., A theoretical treatment of the absorption characteristics of the dithizone mixeducolor system: 1952. (Superseded by Anal. Chemistry, v. 24, no. 10, pp. 1675-76, 1952).

239. Waring, C. Is and Mela, Henry, Jr., The determination of small amounts of rare earths in phosphate rocks: 1952. (Superseded by Anal. Chemistry, v. 25, no: 3, pp. 432-5, 1953)。

244. Cook, $K_{0}$ L. and Moss, C. K., Geophysical observations in parts of the Grants district, McKinley County, New Mexico: 1952; TEI $244, P t 。 1$.

245. Milkey, R. Go, Methods of analysis used in the treatment of Colorado Plateau carnotite for age studies: 1952 .

247. Phair, George, Radioactive Tertiaxy porphyries in the Central City district, Colorado, and their bearing upon pitchblende deposition: 1952.

255. Dings, M. G. and Schafer, Mo, Radiometric reconnaissance in the Garfield and. Taylor Park quadrangles, Chaffee and Gunnison Counties, Colorado: 1953. 
TEI

262. Phair, George and Levine, Harry, Notes on the differential leaching of uranium, radium, and lead from pitchblende in $\mathrm{H}_{2} \mathrm{SO}_{4}$ solutions: 1952. (Superseded by Econ. Geol., v. 48, no, 5, pp. 358.369, 1953).

267. Tucker, W.. and Waring, C. I., The effect of ashing temperatures on the volatility of germanium in lignite samples: 1952.

270. Staff, Trace Elements research quarterly progress report, January 1 to March 31, 1952: 1953: TEI-270, Pt。1.

275. Thompson, M. E., Further studies of the distribution of uranium in rich phosphate beds of the Phosphoria formation: 1952. (To be part of B- 1009)*

280. Staff, Trace Elements research quarterly progress report, April 1 to June 10, 1952: 1953.

281. Vine, J. D. and Moore, G. W., Reconnaissance for uranium-bearing car bonaceous rocks in northwestern Colorado, southwestern Wyoming and adjacent parts of Utah and Idaho: 1952.

285. Weeks, A. D., Mineralogic study of some Jurassic and Cretaceous claystones and siltstones from western Colorado and eastern Utah: 1953.

296. Dings, M. G, Radiometric reconnaissance near Montezuma, Summit County, Colorado: 1953.

308. Beroni, E. P. and McKeown, F. A., Reconnaissance for uraniferous rocks in northwestern Colorado, southwestern Wyoming and northeastern Utah: *

311. Sims, P. Ko and Phair, George, Ceology of the Copper King mine area, Prairie Divide, Larimer County, Colorado: 1952.

317. McKeown, F, A. and Klemic, Harry, Reconnaissance for radioactive materials in northeastern United States during 1952. *; TEI-317A.

318. Rosholt, J. N., Jr., A quantitative radiochemical method for the determination of the major sources of natural radioactivity in ores and minerals: 1953.

324. Portnov, A. I., translated by V. I. Skitsky, The use of aromatic compounds of arsenic in chemical analysis, part I: 1953.

326. Cuttitta, Frank and Kinser, C. A., An improved tubular electric furnace for the closedotube distillation of oil from oil shale: 1953.

328. Finch, W. I., Geologic aspects of the resource appraisal of uranium deposits in pre-Morrison formations on the Colorado Plateau-an interim report: 1953; TEI-328A。 
330, Staff, Search for and geology of radioactive deposits, semiannual progress report, Dec. 1, 1952 to May 31, 1953: 1953.

369. Kostyleva, E. E., translated by Taisia Stadnichenko, On metamictic disintegration of the zircon group of minerals:

390. Staff, Geologic investigations of radioactive deposits, semiannual progress report, June 1 to November 30, 1953: * 


\section{b. Trace Elements Memorandum Reports}

TEM

9. Wyant, $D_{0}$ Go, Treasure Hil1 area, Larimer County, Colorado: 1951; TEM $=9 B$.

10. Wyant, D. Go, Lost Creek (Wamsutter) schroeckingerite deposit, Sweet water County, Wyoming: 1952; TEM-10B.

13. King, R. U., Vein deposits of uranium at the Caribou mine, Boulder County, Colorado: 1952; IEM-13A.

24. King, R。 U. and Granger, H. C., Torbernite occurrence at the Robineau claims, Clear Creek County, Colorado: 1952; TEM-24A.

30. Vhay, J.S., Reconnaissance examination for uranium at six mines and properties in Idaho and Montana: 1951; TEM-30A.

31. Klepper, M。 R., FortyoNiner, King Solomon Ridge, and West End claims near Clancy, Jefferson County, Montana: 1950.

96. Staff, Wamsutter (Red Desert) area, Wyoming, progress report: 1951; TEM-96A.

97. Staff, Colorado Front Range area; progress report: 1951; TEM-97A.

102. King, $R$. U., Investigations in the Wood mine, Colorado: 1951; TEM-102A.

133. Beroni, E. F. and King, R. U。, The Mike Doyle carnotite deposit, EI Paso County, Colorado: 1952; TEM-133A.

145. Kaiser, E. P., The Papsy's Hope autunite prospect, Marysvale district, Piute County, Utah: 1952: TEM-145A。

146. Granger, H. C. and Bauer, H. L., Jro, Results of diamond dxilling, Merxy Widow claim, White Signa.l, Grant County, New Mexico: 1951; TEM-146A。

147. Nelson, R. A., Sharp, W. N., and Stead, F. W., Airborne radioactivity survey of the Red Desert region, Sweetwater County, Wyoming: 1951.

149. Jaffe, E. B. and Sherwood, A. M., Physical and chemical comparison of modern and fossil tooth and bone material: 1951.

165. Staatz, M. Ho and Bauer, H. I., Jro, Preliminary examination of the uranium prospect at the Spider No. 1 claim, Honeycomb Hills, Juab County, Utah: 1950.

167. Staatr, M. H. and Bauex, H. I., Jro, A preliminary report on radioactive fluorite deposits, Thomas Range, Juab County, Utah: 1951; TEM- $167 \mathrm{~A}$. 
TEM

183. Page, L. Ro, Interim report of geologic investigation, Lost Creek schroeckingerite deposits, Sweetwater County, Wyoming: 1950; TEMar $183 \mathrm{~A}$.

232. Davis, W. E., Electrical resistivity investigations of carnotite de. posits in the Colorado Platea: 1951.

236. McKelvey, V.E. Cathcart, J。B。, and Worthing, H。W. Preliminary note on the minor-metal content of Florida phosphate rock: 1951.

251. Weeks, A. D., Red and gray clay underlying ore-bearing sandstone of the Morrison formation in western Colorado: 1951.

252. Fletcher, M. H. and Warner, E, R., A fluorimeter for solutions: 1951. (Superseded by C-311).

255. Stewart, $R_{0} H_{0}$, Radiometric reconnaissance examination in southeastern Pennsylvania and western New Jersey: 1951.

306. Sakakura, A. $\mathcal{I}_{0}$, Theory of gamma-ray logging: preliminary calculations: 1951.

323. Wedow, Helmuth, Ix, Adaptation of portable survey meters for airborne reconnaissance with light planes in Alaska: 1951.

336. Duncan, D. C., Preliminary report on a uranium-bearing rhyolitic tuff deposit near Coaldale, Esmeralda County, Nevada: 1952. (Supero seded by $(-291)$.

337. Davidson, D. F., Relation of "topography" of the Hawthorn formation to size of phosphate particles in the deposits, and to topography in the northern part of the land-pebble phosphate field, Florida: 1952.

360. Moxham, R. Mo Airborne radioactivity surveys in the Mojave Desert region, Kern, Riverside, and San Bernardino Counties, California: 1952.

362. Davidson, D. F., Grain size distribution in the surface sands, and the economic phosphate deposits of the landeupeble phosphate district, Florida: 1952 .

434. Schnabel, $R_{0}, W_{0}$ and Vickers, $R, C$, Reconnaissance of the Clinton formation in New York, Pennsylvania, Maryland, and New Jersey: 1953.

444. Duncan, D. C., Results of reconnaissance for uranium in nonmarine carbonaceous rocks in parts of California, Idaho, Nevada, Oregon, Utah, and Washington during 1951 and 1952: TEM $444-A_{\text {, * }}$.

445. Tourtelot, H. A., Reconnaissance for uraniferous rocks in northeastern Wind River Basin, Wyoming: 1952. 
509. Manger, G. E. and Gates, G. L., Progress report on original-state core studies (Joint report $=$ USGS and Bureau of Mines): 1953.

676. Davidson, Do Fo, Distribution of coarse and fine-grained rocks in the Wasatch formation and their relationship to uranium deposits, Powder River Basin, Wyoming: 1953.

677. Davidson, D。F。, Reconnaissance for uranium in the Powder River Basin, Wyoming: 1953. 


\section{CIRCULARS}

Free on application to the

Geological Survey, Washington 25, D. C.

(* Indicates Circular is in process)

Cir. No.

74. Frondel, J. W. and Fleischer, Michael, A glossary of uranium- and thoriumwearing minerals, Apr. 1950 (TEI-103). (Superseded by C-194).

111. Stokes, W. L., Carnotite deposits in the Carrizo Mountains area, Navajo Indian Reservation, Apache County, Arizona, and San Juan County, New Mexico, May 1951.

135. Jaffe, E, B, Abstracts of the literature on synthesis of apatites and some related phosphates, Dec. 1951 (TEI-132, pt. I).

137. Kaiser, E. Po, Uraniferous quartzite, Red Bluff prospect, Gila County, Axizona, Oct. 1951 (TEM-210).

142. Staatz, $M_{*} H_{*}$ and Bauer, $H_{*} I_{0}, J r_{0}$, Virgin Valley opal district, Humboldt County, Nevada, Dec. 1951 (TEMw227).

175. Page, $L, R$, and Redden, J. A., Carnotite prospects of the Craven Canyon area, Fall River County, South Dakota, Mar. 1952 (TEM-152).

176. Love, J. D., Preliminaxy report on uranium deposits in the Pumpkin Buttes area, Powder River Basin, Wyoming, Mar. 1952.

184. Moxham, $R, M_{*}$ and Nelson, A. E, Reconnaissance for radioactive deposits in south-central Alaska, 1947-1949, Aug. 1952 (TEI-48, -191, TEM-326).

185. White, $M, G$, Reconnaissance for radioactive deposits along the upper Porcupine and lower Coleen Rivers, northeastern Alaska, July 1952 (TEI-55, -57B).

186. Moore, F. B. and Butler, C. R., Pitchblende deposits at the Wood and Calhoun mines, Central City mining district, Gilpin County, Colorado, Oct. 1952 (TEM-198).

189. Granger, H. C and Bauer, H, I*, Jr, Uranium occurrences on the Merry Widow claim, White Signal district, Grant County, New Mexico, Oct. 1952 (TEI 157 ).

194. Frondel, J.W. and Fleischer, Michael, A glossary of uranium and thorium-bearing minerals, second edition, June 1952 (Revision of $(\mathrm{C}-74)=$ 
Cir. No.

195. White, M, G, Radioactivity of selected rocks and placer concentrates from nor theastern Alaska, Oct. 1952 (TEI-57C, TEM-327).

196. White, M. G., West, W. S., Tolbert, G, E, Nelson, A. E, and Houston, $J . R_{0}$, Preliminary summary of reconnaissance for uranium in Alaska, 1951, June (1952 (TIM-319, 320, 32I, 32.2).

199. Grimaldi, F: S。, May, Irving, and Fletcher, M. H, U, S. Geological Survey fluorimetric methods of uranium analysis, Nov. 1952 (TEI-219).

202. Bates, $R_{*} G_{*}$ and Wedow, Helmuth, Jr. Preliminary summary review of the thorium-bearing mineral occurrences in Alaska, Jan. 1953 (TEM-339).

207. Moxham, R. M. and Nelson, A. Eo, Reconnaissance for radioactive de posits in the southern Cook inlet region, Alaska, 1949, Dec, 1952 (TEI-74A, - 190).

208. McKelvey, $V_{0} E_{0}$, and others, Stratigraphic sections of the Phosphoria formation in Idaho, 1947 48 , Part I, Apr. 1953 (TEI-183).

209. Swanson, R. W., and others, Stratigraphic sections of the Phosphoria formation in Montana, 1947 48, May 1953 (pto of TEI-186).

210. McKelvey, $V_{0} E_{0}$ and others, Stratigraphic sections of the Phosphoria formation in Wyoming, 1947-48, May 1953 (TEI-184).

211. Smith, I, E, and others, Stratigraphic sections of the Phosphoria formation in Utah, 1947 48, Apr. 1953 (TEI-185).

212, Vine, Jo D, and Moore, G. W, Uranium bearing coal and carbonaceous rocks in the Fall Creek area, Bonneville County, Idaho, Nov. 1952 $(15 E-340)$.

213. Harrison, J. E, and Leonard, $B, F$, Preliminary report on the Jo Reynolds area, Lawson $=$ Dumont district, Clear Creek County, Colorado, Dec. 1952 (TEM-153).

214. West, $W_{0} S_{0}$ and White, $M_{0}, G_{0}$, The occurrence of zeunerite at Brooks Mountain, Seward Peninsula, Alaska, Dec. 1952 (TEI-221).

215. King, $R, U_{0}$, and others, Uranium in the metal-mining districts of Colorado, Apr. 1953 (TEI-173).

217. Benson, W. E。, Trites, A. F。, Jx。, Beroni, E. P., and Feeger, J. A, Preliminary report on the White Canyon area, San Juan County, Utah, Nov. $1952(T E M-325)$.

219. Gott, G, B, and Erickson, R, I, , Reconnaissance of uranium and copper deposits in parts of New Mexico, Colorado, Utah, Idaho, and. Wyoming, Dec. 1952 (TEI-232, pt。 1).

220. Kaiser, E. P., and others, Selected papers on uranium deposits in the United States, Dec. 1952 (TEI-168). 
Cir. No.

224. Waters, A, C. and Granger, H. C., Volcanic debris in uraniferous sandstones, and its possible bearing on the origin and precipitation of uranium, Jan. 1953 (TEI-170).

234. Stich, J. N., Spectrographic identification of mineral grains, Jan. $1953(T E I-274)$.

236. Burbank, W. So and Pierson, C. T., Prellminary results of radiometric reconnaissance of parts of the northwestern San Juan Mts., Colorado, Feb。 $1953(T E M=310)$.

239. Beroni, E. P., McKeown, F. A., Stugard, Frederick, Jr。, and Gott, G. B., Uranium deposits of the Bulloch group of claims, Kane County, Utah, Max. 1953 (TEM-213).

244. White, Mo Go, West, W. Sos and Matzko, Jo Jo, Reconnaissance for radiow active deposits in the vicinity of Teller and Cape Nome, Seward Peninsula, Alaska, 1946-47, Feb. 1953 (TEI-40, -45, pt。2).

245. Lang, $A_{0} J_{0}, J_{0}$, and Redden, J.A., Geology and pegmatites of part of the Fourmile area, Custer County, South Dakota, Mar. 1953 (TEI-155, pt. 1).

248. Wedow, Helmuth, Jr., and others, Preliminary summary of reconnaissance for uranium and thorium in Alaska, 1952, Mar. 1953 (TEM-552).

250. Gault, $H_{0} R_{0}$, and others, Reconnaissance for radioactive deposits in the northeastern part of the Seward Peninsula, Alaska, 1945 447 , and 1951, Apse. 1953 (TEI-25, -41, pt. 1, -42, pt. 2, -49, TEM-355)。

251. Hail, W. J., Jro, and Gill, J.R., Results of reconnaissance for uraniferous coal, Iignite, and carbonaceous shale in western Montana, Mar. 1953 (TEMoot46).

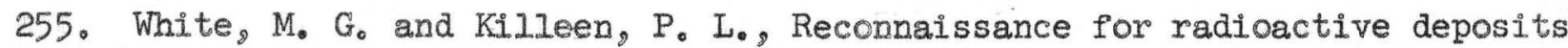
in the lower YukonwKuskokwim Highlands region, Alaska, Apr. 1953 (TEI 45, pto 1, -46 ).

260. Klepper, Mo R., and others, Stratigraphic sections of the Phosphoxia formation in Montana, 1948, Sept. 1953 ( $p t_{0}$ of TEI-186).

262. O'Malley, F。 Wo, and others, Stratigraphic sections of the Phosphoria formation in Idaho, part III, Sept. 1953 (TEI-188).

264. Cannon, H. I., Geobotanical reconnaissance near Grants, New Mexico, Apr. $1953(T E M-272)$.

265. Moxham, $R, M_{0}$ and West, $W_{0} S_{0}$, Radioactivity investigations in the Serpentine-Kougarok area, Seward Peninsula, Alaska, 1946, Apr。 1953 (IEI-39). 
Cir. No.

271. Stieff, L. Ro, Stern, T. Wo, and Milkey, R. Go, A preliminary determination of the age of some uranium ores of the Colorado Plateau. by the lead-uranium method, July 1953 (TEI-268)。

277. Becraft, C. E。, Preliminary report on the Comet area, Jefferson County, Montana, Sept。 1953 (TEI 282 )。

278. Love, J. Do, Preliminary report on uranium deposits of the Miller Hill area, Carbon County, Wyoming, July 1953 (TEI-315, pt。1).

279. White, $M_{0} G_{0}$ and Stevens, J。 Mo, Reconnaissance for radioactive deposits in the Ruby -Poorman and Nixon-Fork districts, west centraI Alaska, 1949, Aug。 1953 (TEI-75, -192).

281. Curtis, Diane and Houser, S. So, Bibliography of U. S. Geological Survey Trace Elements and related reports, Sept. 1953 (pt. 2 of TEI-301)。

286. Vickers, R。C., An occurrence of autunite, Lawrence County, South Dakota, July 1953 (TEM-559)。

290. Christman, R. A. Heyman, A. M., Dellwig, I. F。, and Gott, G. B., Thorium investigations, 1950-1952, Wet Mountains, Colorado, Nov. 1953 (TEI-250).

291. Duncan, D. C., A uranium bearing rhyolitic tuff deposit near Coaldale, Esmeralda County, Nevada, Aug。 1953 (TEM-336).

294. Pierson, C.T. and Singewald, Q。 Do, Results of reconnaissance for radioactive minerals in parts of the Alme district, Park County, Colorado, Sept。 1953 (TEI-248, pt。1)。

297. Swanson, $R_{0} W_{0}, M c K e l v e y, V_{0} E_{0}$, and Sheldon, R。 P., Progress report on investigations of western phosphate deposits, Nov. 1953 (TEI-246, pt。1)。

300. West, W. S., Reconnaissance for radioactive deposits in the Darby Mountains district, Seward Peninsula, Alaska, 1948, Nov. 1953 (TEI-53)。

301. McKelvey, V. E。, and others, Stratigraphic sections of the Phosphoria formation in Idaho, 1947-48, part II, Nov, 1953 (TEI-187).

302. Cressman, E。 R。, and others, Stratigraphic sections of the Phosphoria formation in Montana, 1949-50, part I, Nov。 1953 (TEI-361).

303. Swanson, R. Wo, and others, Stratigraphic sections of the Phosphoria formation in Montana, 1949-50, part II, Dec. 1953 (TEI-362)。

304. Sheldon, R. Po, Stratigraphic sections of the Phosphoria formation in Idaho, 1949, part I, Nov. 1953 (TEI-364). 
Cir. No.

305. Davidson, D. F., and others, Stratigraphic sections of the Phosphoria formation in Idaho, 1949, part II, Dec. 1953 (TEI-365).

306. Cheney, T. M., and others, Stratigraphic sections of the Phosphoria formation in Utah, 1949 51, Nov, 1953 (TEI- 360).

307. Sheldon, R。 P., and others, Stratigraphic sections of the Phosphoria formation in Wyoming, 1949-50, Dec. 1953 (TEI-363).

309.* Griffitts, W. R., Beryllium resources of the tinmspodumene belt, North Carolina, (IEI-249, pt. 1).

311. Fletcher, M. H. and Warner, E. R., A fluorimeter for solutions, $(T E M=252)$.

312.* Wilmarth, V. R, and others, Yellow Canary uranium deposits, Daggett County, Utah, (TEI-124, pt. 1).

313. Moore, G. W. and Stephens, J. C., Reconnaissance for uraniumbearing carbonaceous rocks in California and adjacent parts of Oregon and Nevada, (TEI-337).

316.* Wedow, Helmuth, Jr., Reconnaissance for radioactive deposits in the Eagle-Nation area, eastwcentral Alaska, 1948, (TEI-56).

317. Moxham, $R, M_{*}$, Reconnaissance for radioactive deposits in the Manley Hot Springs-Rampart district, central Alaska, 1948, (TEI-54).

319. * Wite, $M_{0} G_{0}$ and West, $W . S .$, Reconnaissance for uranium in the Lost River area, Seward Peninsula, Alaska, 1951, (TEI-220).

320. * Adams, J. W., and others, Uranium occurrences in the Colden Gate Canyon and Ralston Creek areas, Jefferson County, Colorado, (TEM-154, pt. 1).

321. * Singewald, Q. D. and Pierson, C, T., Occurrance of uranium-bearing minerals in the St. Kevin district, Lake County, Colorado, (TEI 234, pt. 1).

322.* Wyant, $D_{*} G_{*}$, The East Slope No. 2 uranium prospect, Piute County, Utah, $(\mathrm{TEM}-211)$.

324.* Cheney, T. M*, and others, Stratigraphic sections of the Phosphoria formation in Wyoming, 1951, (TEI-377).

325.* Sheldon, R. P., and others, Stratigraphic sections of the Phosphoria formation in Wyoming, 1952, (TEI-378).

326.* Peterson, J. A., Gosman, R. F., and Swanson, R. W., Stratigraphic sections of the Phosphoria formation in Montana, 1951, (TEI-375). 
Cir. No.

327. * Smart, $R_{0} A_{0}$, and others, Stratigraphic sections of the Phosphoria formation in Idaho, 1950 -51, (TEI-376).

328. West, W. S., Reconnaissance for radioactive deposits in selected areas of the lower Yukon-Kuskokwim region, Alaska, 1952, (TEI-291). 


\section{BULLETINS}

For sale by the Superintendent of Documents,

$\mathrm{U}_{3} \mathrm{~S}$. Government Printing Office

Washington 25, D. C., at the price indicated.

(* Indicates Bulletin is in process)

BuIl. No.

936. Strategic minerals investigations, 1942.

(Issued only in separate chapters)

(P) Fischer, $R_{0}, P_{0}$, Vanadium deposits of Colorado and Utah, a preliminary report, 1942. $30 \phi$

982. Contributions to economic geology, 2952.

(Issued only in separate chapters)

(D) Adams, Jo $W_{0}$, Beryllium deposits of the Mt. Antero region, Chaffee County, Colorado, Apr. 1953. (TEI-126). 15ф

988. Contributions to the geology of uranium, 1952.

(Issued only in separate chapters)

(A) Fischer, $R, P$ and Hilpert, $L, S$, Geology of the Uravan mineral belt, Sept. 1952. (Revised TEI-109). 35\&

(B) Weir, Doris Blackman, Geologic guides to prospecting for carnotite deposits on Colorado Plateau, Aug. 1952. (TEI-219). $15 \%$

(C) Staatr, $M_{0} H_{0}$ and Bauer, $H_{0} I_{0}, J r$, , Uranium in the East Walker River area, Lyon County, Nevada, Feb. 1953 (TEM-228). $35 \phi$

(D) Thompson, $M_{*} E_{0}$, Distribution of uranium in rich phosphate beds of the Phosphoria formation, Jan. 1953. (TEI 142). $15 \phi$

(E) Gott, G. B, and Hill, J.W., Radioactivity in some oil fields of southeastern Kansas, Apr. 1953. (TEI-121). $\$ 1.00$

(F) Roberts, W。 A。 and Gude, A. Jo, 3rd, Uraniumbearing deposits west of Clancy, Jefferson County, Montana, June 1953. (TEM-229). $45 \%$

(G) Roberts, W. A. and Gude, A. Jo, 3rd., Geology of the area adjacent to the Free Enterprise mine, Jefferson County, Montana, Dec. 1953. (TEM-140)。 \$1.50 
Bu11. No.

988. Contributions to the geology of uranium, 1952. (Continued)

(H) Trites, A. F., Jr., and Tooker, E. W., Uranium and thorium deposits in east-central Idaho, southwestern Montana, Oct. 1953. (TEI-140). 35\%

(I) Nelson, J. M., Prospecting for uranium with car-mounted equipment, Oct. 1953. (TEI-65). $15 \%$

992. Contributions to geochemistry, 1949.

Brannock, $W_{*} W_{0}$, and others, Contributions to geochemistry, 1949, Aug. 1953. (TEI $=60,-99,-152,-210) .65 \phi$

1005.* Thurston, $W_{*} R_{*}$, and others, Fluorspar deposits of Utah. (Includes TEI-136).

1006:* Edited by Grimaldi, F。 S., May, Irving, Fletcher, $M_{0} H_{*}$, and Titcomb, Jane, Collected papers on methods of analysis for uranium and thorium developed by the U. S. Geological Survey. (TEI-23, -31A, $-31 B,-3 I C,-3 I D,-3 I E,-44,-47,-98,-104,-105,-120,-130$, $-133,-134,-135,-153 \mathrm{~A},-178,-181, \mathrm{TEM}-316)$.

1009.* Contributions to the geology of uranium, 1953.

(Issued only in separate chapters)

(A)* Wilmarth, V. R. and Johnson, D. H., Uranophane at Silver Cliff mine near Lusk, Wyoming. (TEI-158).

* Craig, L. C., and others, Preliminary report on the stratigraply of the Morrison and related formations of the Colorado Plateau region. (TEI -180$)$.

* Lovering, T. G, Radioactive deposits of Nevada. (TEI-169).

* Thompson, M. E., Further studies of the distribution of uranium in rich phosphate beds of the Phosphoria formation. (TEI-275).

* Thurston, R. H. and Trites, A. F., ir., The uranium, tin, and copper deposits at Majuba Hill, Pershing County, Nevada. (TEI-171).

* Wyant, D. G., Sharp, W. N*, and Sheridan, D. W., Uranium deposits in the Red Desert of the Great Divide Basin, Sweetwater County, Wyoming. (TEI-122).

1011. * Thurston, $W, R_{*}$, Pegmatites of the Crystal Mountain district, Larimer County, Colorado. (TEI-139). 
Bul1. No.

1015. Contributions to economic geology, 1954.

(Issued only in separate chapters)

* Cressman, $E_{*} R_{0}$ and Gulbrandsen, $R_{*} A_{*}$, Geology of the Dry Valley quadrangle, Idaho. (TEI-258).

* Sheridan, Douglas M., Geology of the High Climb pegmatite, Custer County, South Dakota. (TEI=23I). 


\section{PROFESSIONAI PAPERS}

For sale by the Superintendent of Documents,

U. S, Government Printing Office

Washington $25, D_{0} C$, at the price indicated.

(* Indicates Professional Paper is in process)

P. No.

227. Hanley, $J_{*} B_{*}$, Heinrich, $E_{\text {. }} W_{m}$, and Page, I. R, Pegmatite investigations in Colorado, Wyoming, and Utah, 1942-44: 1950. \$1.50

261. *1son, J.E., and others, Rare-earth mineral deposits of the Mountain Pass district, San Bernardino County, California: (Includes T्EI-251)

265.* Staatz, M. H, and Trites, A, F, Jr., Geology of the Quartz Creek pegmatite district, Gunnison County, Colorado: (TEI-138) 


\section{U. S, GEOLOGICAL SURVEY OII AND GAS MAPS AND}

MINERALS INVESTIGATIONS PRELIMINARY MAPS AND REPORTS

\section{(* Indicates publication is in process)}

If copies are available, they may be obtained by application to the Director, Geological Survey, Washington 25, D, C.; or to the Distribution Section, Geological Survey, Denver Federal Center, Denver, Colorado.

a. Fischer, R. P., Stokes, W. I., and Smith, L. E., Geology of the Rifle Creek vanadium area, Garfield County, Colorado: U. S. Geol. Survey Strategic Minerals Investigations Preliminary Report (mimeographedlimited distribution). 1944.

b. Fischer, $R_{0} P_{0}$, Vanadium region of southwestern Colorado and southeastern Utah: U. S. Geol. Survey Strategic Minerals Investigations Prew liminary Map (with text). 1944. (Second edition issued as Straw tegic Minerals Investigations Preliminary Map 3-226, 1949. 30\%)

c. Huddle, J. W. and McCann, F. T*, Geologic map of the Duchesne River area, Wasatch and Duchesne Counties, Utah: U. S, Geol. Survey Pre= liminary 011 and Gas Map No. 75, Sept. 1947.60ф

d. Huddle, J. W., Mapel, W. J., and McCann, F. T, Geology of the Moon Lake area, Duchesne County, Utah: U.S. Geol. Survey Oil and Gas Map Series, OM-125, 1951.50ф

e. Hunt, C. B., and others, Geologic map of the Henry Mountains region, Utak: U. S. Geol. Survey Oil and Gas Map Series, OM-13I, May 21, 1952. $\$ 1.00$

f. Kinney, D. M, Geology of the Uinta River and Brush Creek-Diamond Mountain area, Duchesne and Uintah Counties; Utah: U. S. Geol. Survey 011 and Gas Map Series, OM-123, 1951. $75 \phi$

g. Love, J. D., Henbest, I, Go, and Deason, No M, Stratigraphy and paleonio tology of Paleozoic rocks, Hartville area, eastern Wyoming: U. S Geol. Survey $0 i 1$ and Gas Investigations Chart 44, 1953. 2 sheets. $\$ 1.00$ per set.

h. Sharp, W. No and Pray, L, C, Geologic map of bastnaesite deposits of the Birthday claims, San Bernardino County, California: U. S, Geol. Survey Mineral Investigations Field Studies Map 4, 1952.

i. Stokes, W. Io, Russe11, R. T., Fischer, R, Po, and Butlex, A, Po, Jx., Geologic map of the Gateway area, Mesa County, Colorado, and adjoining part of Grand County, Utah: U. S. Geol. Survey Strategic Minerals Investigations Preliminary Map (with text) 3×173, 1945. $25 \phi$ 
3. Stokes, W, I, and Phoenix, D. A., Geology of the Egnar-Gypsum Valley area, San Miguel and Montrose Counties, Colorado: U. S. Geol. Survey $0 i 1$ and Gas Investigations Preliminary Map 93, 1948. 50\%

k. Strobell, J. $\mathrm{D}_{*}, \mathrm{Jr}$., Geology of the Carrizo Mountains area in northeastern Arizona and northwestern New Mexico: U. S. Geol. Survey Oil. and Gas Investigations Map Series, * (TEM-415-430 inclusive). 


\section{GEOLOGIC QUADRANGIE MAP SERIES \\ (* Indicates publication is in process)}

When published, these maps may be purchased, flat or folded, from the U. S. Geological Survey, Washington 25, D. C.

Anderson Mesa, Montrose and San Miguel Counties, Colorado. Geology of', by Fred W. Cater, Jr., with a section on "The Mines" by C. F. Withington: * (TEM-690).

Atkinson Creek, Montrose County, Colorado. Geology of, by E. J. McKay: * (TEM-691).

Bul1. Canyon, Montrose and Sen Miguel Counties, Colorado. Geology of, by Fred W. Cater, Jr.: * (NEM-692).

Calamity Mesa, Mesa County, Colorado. Ceology of, by Fred W. Cater, Jr.: * (IMM-693).

Davis Mesa, Montrose County, Colorado. Geology of, by Fred with a section on "The Mines" by Leonid. Bryner: * (TEM-694).

Egnar, Dolores and San Miguel Counties, Colorado. Geology of, by Fred. W. Cater, Jr., with a section on "The Mines" by A. L. Bush and Henry Bell, III: * (TEM-695).

Gateway, Mesa County, Colorado. Ceology of, by Fred W. Cater, Jr.: * (TEM-696).

Gypsum Gap, San Miguel County, Colorado. Geology of, by Fred W. Cater, Jr.: * (TEM-697).

Hamm Canyon, San Miguel County, Colorado. Geology of, by Fred W. Cater, Jr。: * (TEM-698).

Horse Range Mesa, San Miguel County, Colorado. Geology of, by Fred W. Cater, Jr., with a section on "The Mines" by A. L. Bush, Henry Be11, III, and C. F. Withington: * (TEM-699).

Joe Davis Hill, Dolores and San Miguel Counties, Colorado. Geology of, by Fred. W. Cater, Jr., and Henry Bell, III: * (TEM-700).

Juanita Arch, Mesa County, Colorado. Geology of', by E. M. Shoemaker: * (TEM-701).

Naturita NW, Montrose and San Miguel Counties, Colorado. Geology of, by Fred W. Cater, Jr., with a section on "The Mines" by J. D. Vogel: * (TEM-702). 
Paradox, Montrose County, Colorado. Geology of, by C. F. Withington: * (TEM-703).

Pine Mountain, Mesa County, Colorado. Geology of, by Fred. W. Cater, Jr.: * (TEM-704).

Red Canyon, Montrose County, Colorado. Geology of, by E. J. McKay, with a section on "The Mines" by D.A. Jobin: * (TEM-TOS). 


\section{PUBLICATIONS IN SCIENTIFIC JOURNALS}

Exclusive of "Nuclear Science Abstracts"

\section{(Publications are listed alphabetically by authors)}

1. Adams, J. W. , Uranium in the Golden Gate Canyon and Ralston Creek areas, Jefferson County, Colorado (abs.): Geol. Soc. Am. Bull., v. 64, no. 12, pt. 2, p. 1539, 1953. (TEM-15!)

2. Altschuler, Z. S, and Cisney, E. A., X-ray evidence of the nature of the carbonate-apatites (abs.): Geol. Soc. Am. Bull., v. 63, no. 12, pt. 2, p. 1230, 1952.

3. Armstrong, F. C., Pitchblende deposits on Quartz Hill, Central City district, Gilpin County, Colorado (abs.): Geol. Soc. Am. Bull., v. 63, no. 12, pt. 2, p. 1232, 1952; (abs.): Econ. Geology, v. 47 , no. $7, \mathrm{pp} .767-768,1952$.

4. Axelrod, J., Grimaldi, F. S., Milton, Charles, and Murata, K. J., The uranium minerals from the Hillside mine, Yavapi County, Arizona: Am. Mineralogist, v, 36, nos. 1 and 2, pp. 1-22, 1951.

5. Bales, W. E., Bell, Henry, III, and Wilmarth, V. Ra, Uranium-vanadiun deposits near Edgemont, Fall River County, South Dakota (abs.): Geol. Soc. Am. Bull., v. 64, no. 12, pt. 2, p. 1540, 1953.

6. Becraft, G. E., Uranium deposits in the northern part of the Boulder Batholith (abs.): Geol. Soc. Am. Bull, v, 64, no. 12, pt. 2, p. $1540,1953$.

7. Becraft, G. E. and Rosenblum, Saruel, Petrographic features of the northeastern part of the Boulder Batholith (abs.): Geol. Soc. Am. Bul1., v. 64, no. 12, pt. 2, p. 1540, 1953.

8. Berman, Joseph, Studies of metamict minerals (I): Methods and procedures (abs.): Geol. Soc. Am. Bull, , v. 62, no, 12, pt. 2, p. 1422, 1951.

9. Berman, Joseph, Studies of metamict minerals (II): Re-examination of fergusonite (abs.): Geol. Soc. Am. Bul1., v. 63, no. 12, pt. 2, p. $1235,1952$.

10. Berman, Robert, A nomogram for obtaining percent composition by weight from mineral-grain counts: Jour. Sed. Petrology, v. 23, no. 2, pp. 120-123, 1953. (TEI-273)

11. Cannon, Helen, The effect of uranium-venadium deposits on the vegetam tion of the Colorado Plateau: Am. Jour. Sci., v. 250, pp. 735-770, Oct. 1952. (TEI-160) 
12. Cannon, R. S., Jr., Nature of orewlead (abs.): Geol. Soc. Am. Bull,, v. 61 , no. 12 , pt. 2, p. $1448,1950$.

13. Cathcart, J. B., Notes on the land-pebble phosphate deposit of Florida: in Symposium on Mineral Resources of the southeastern United States (1949 proc.), Univ。 of Tenn。 press, pp。132-151, 1950.

14. Cathcart, J, Bo and Davidson, D, F, , Distribution and origin of phosphate in the landapebble phosphate district of Florida (abs.): Econ。Geology, v, 47, no, I, p. 127, Jan, $=F$ Feb, 1952. (TEI-212)

15. Cathcart, J。 Bo and Houser, F。 $\mathbb{N}_{0}$, Development and distribution of leached rock in the land-pebble phosphate district, Florida (abs.): Geol. Soc.Am. Bull., v。 61, no, 12, pt. 2, p. 1449, 1950.

16. Christ, C, I, Clark, Jo R, and Evans, H, To, Jro, The crystal structure of $\mathrm{KVO}_{3}{ }^{\circ} \mathrm{H}_{2} \mathrm{O}:$ Jour. Chem, Physies, v. 21, no. 6, p. 1114 , June, 1953.

17. Conant, I, C., Shallow-water origin of the Chattanooga shale (abs.): Geol. Soc.Am.Bu11., v. 64, no. 12, pt. 2, pp. 1529-30, 1953. (TEI-237).

18. Craig, I, Co and Holmes, Clifford, The Morrison formation of the Colorado Plateau region, progress report (abs.): Am. Assoc. Petrol. Geol. Bull., v。 35, no, 5, p. 1108, 1951.

19. Cressman, E, R, , Stratigraphy of the Phosphoria formation in part of southwestern Montana (abs.): Geol. Soc. Am.Bül., v. 64, no. 12 , pt. 2, pp. 1543-4, 1953.

20. Deul, Maurice and AnnelI, C. S. The concentration of minor and trace elements in ash of low-rank coals from Texas, Colorado, North and South Dakota (abs.): Geol. Soc. Am. Bull., v. 63, no, 12, pt, 2, p. 1243, 1952; (abs.): Econ. Geology, v. 47, no. 7, p. 770, 1952.

21. Donnay, Gabrielle, Roentgenite, $3 \mathrm{CeFCO}_{3}, 2 \mathrm{CaCO}_{3}$ a new mineral: $\mathrm{Am}$. Mineralogist, v. 38 , nos. 9 and 10 , pp. 868-870, 1953.

22. Donnay, Gabrielle and Donnay, J, D. H.; The cxystallography of bastnaesite, parisite, poentgenite and synchisite: Am. Mineralogist, v. 38, nos. 11 and 12, pp. 932-963, 1953.

23. Donnay, Gabrielle and Donnay, $J_{0} \mathrm{D}_{\circ} \mathrm{H}_{s}$, Tyuyamunite, carnotite, and sengierite (abs,): Geol, Soc.Am。Buil, v. 64, no. 12, pt. 2, pp. 1412m13, 1953.

24. Exickson, R. L., Gott, G, B., Myers, A, T., and Horr, C. A, Association of uranium and other metals with crude oils, asphalts, and petroliferous rocks (abs.) Geol. Soc. Am. Bull., v。 64, no. 12, pt. 2, pp. 1505-6, 1953. (TEM-513). 
25. Evans, $\mathrm{H}_{0} \mathrm{~T}_{0}, \mathrm{Jr}_{0}$, and Block, Stanley, Crystal structure of $\mathrm{KVO}_{3}$ (abs.): Geol. Soc. Am. Bul1., v. 64, no. 12, pt. 2, p. 1419, 1953.

26. Evans, $H_{0}$ To, J $_{0}$, and Block, Stanley, The crystal structure of montroseite, a vanadium member of the diaspore group: Am. Minerglogist, v. 38, nos. 11 and 12, pp. 1242-1250, 1953. (TEI-368)

27. Evans, $H_{0} T_{0}, J x_{0}$, and Mrose, $M_{0} E_{0}$, Alteration processes in montroseite (abs.): Geol. Soc, Am. Bull., v. 64, no. 12, pt. 2, p. 1419, 1953.

28. Faul, Henry, Radioactivity methods: in Exploration Geophysics (edited by J.J. Jakosky), Chapter 10, Los Angeles, 1950.

29. Faul, Heary, Gott, G. B. Manger, G. E, Mytton, J. W., and Pierce, A. P.s Radioactivity of the helium bearing formations of the Texas Pan handle region (abs.): Ceol. Soc. Am. Bull, v. 64, no. 12, pt. 2, pp. 1420-1421, 1953. (TEM-533)

30. Faul, Henry and Tittle, C. W., Logging of drill holes by the neutron, gamma method, and gamma-ray scattering: Geophysics, $v_{0} 16$, no. 2, pp. 260-276, 1951 .

31. Finch, Warren $I_{0}$, Distribution of uranium deposits in the Shinarump conglomerate of the Colorado Plateau (abs.): Econ。Geology, v, 48, no. 7, p. 619, 1953; (abs.): Geol. Soc. Am. Bull, v. 64, no. 12 , pt. 2, p.1422, 1953. (TEI-328)

32. Fischer, $R_{0} P_{0}$, Deposits of vanadiumwbeaxing sandstone: in Vanderwilt, J. W. Mineral Resources of Colorado, pp.451.456, Colorado Mineral Resources Board, $194 \%$

33. Fischer, R, P. Federal exploration for carnotite ore: Colorado Mining Association, special publication, Denver, Colo., 1949.

34. Fischer, R。 Po, Uraniumbearing sandstone deposits of the Colorado Plateau: Econ. Geology, v. 45, no. I, pp。 loll, 1950.

35. Fischer, $R_{0} P_{0}$, Haff, J。 $C_{0}$, and Rominger, J.F., Vanadium deposits near Placervilie, San Miguel County, Colorado: Colorado Sci. Soc. Proc., v. 15, no. 3, pp. 115-134, 1947 .

36. Fleischex, Michael and Rabbitt, JoC., Geochemistry: Ann. Rev. Nuclear Sc1. 1, pp. 465 $4478,1952$.

37. Frondel, Clifford, Hydroxyl substitution in thorite and zircon: Am. Mineralogist, v. 38, nos. 11 and 12, pp. 1007-1018, 1953. (TEIw327)

38. FrondeI, J. W. Studies of uranium minerals (VII): Zeunerite: Am. Mineralogist, $v, 36$, nos。 3 and 4, pp. 249w255, 1951。

39. Frondel, JoW. and Cuttitta, Frank, Studies of uranium minerals (XII): The status of billietite and becquerelite: Am. Mineralogist, vo 38, nos. 11 and 12, pp. 1019.1024, 1953: (abs.): Geol. Soc. Am. Bull., v. 63, no. 12, pt. 2, p. 1253, 1952. (TEI-309) 
40. Garrels, R. M, Some thermodynamic relations among the vanadium oxides, and their relation to the oxidation state of the uranium ores of the Colorado Plateau: Am. Mineralogist, v. 38, nos. 11 and 12 , pp. 1251-1265, 1953: (abs。): Geol. Soc. Am. Bullo, v。 64, no. 12, pt. 2, p. 1426, 1953 .

41. Gillerman, Elliot, Uranium deposits in the Blackhawk district, Grant County, New Mexico (abs.): Geol.Soc. Am. Bull., v. 63, no. 12, pt. 2, p. 1254, 1952.

42. Gillerman, Elliot, Uranium deposits of the White Signal district, New Mexico (abs.): Geol, Soc. Am, Bull., v。63, no. 12, pt. 2, p. 1329, 1952.

43. Gott, G. B, Wyant, D. G., and Beroni, $E_{0}, P_{0}$, Uranium in black shales, lignites, and limestones in the United States (abs.): Geol. Soc. Am. Bul1., v. 62, no. 12, pt. 2, p. 1535, 1951. (part of TEI-168)

44. Hanley, J. B., Economic geology of the Rincon pegmatites, San Diego County, California: California State Division of Mines Special Report 7B, 1951. 35\%

46. Harrison, $J \cdot E_{*}$, Relation between fracture pattern and hypogene zoning in the Freeland-Lamartine district, Clear Creek County, Colorado (abs.): Geol. Soc. Am. Bull。, v. 64, no, 12, pt. 2, p. 1431, 1953.

47. Hewett, D, F。 and Glass, Jewell J., Two uraniumbearing pegmatite bodies in San Bernardino County, California: Am. Mineralogist, v. 38, nos. 11 and 12, pp. 1040-1050, 1953.

48. Holmes, $C . N_{s}$, The effect of the Uncompangre uplift on the Mesozoic sedimentary rocks of Colorado (abs.): Geol. Soc. Am. Bull., v, 61, no. 12 , pt. 2, p. $1470,1950$.

49. Holser, W. T., Beryllium minerals in the Victorio Mountains, Iuna County, New Mexico: Am. Mineralogist, v. 38, nos. 7=8, pp. 599611, 1953. (TEI-166)

50. Holser, W, T., Warner, $I_{*} A_{*}$, Wilmarth, V. R., and Cameron, E. N, Notes on the geochemistry of beryllium (abs.): Geol. Soc, Am. Bull., v. 62 , no. 12, pt. 2, p. $1450,1951$.

51. Honkala, Fred $S_{0}$, Phosphatic rocks in the Centennial Range, MontanaIdaho (abs,): Geol. Soc. Am, Bull., v. 64, no, 12, pt. 2, p. 1547 , 1953. (TEI-323)

52. Huleatt, Wm. $\mathrm{P}$, Wagon-drill sampling by U, S. Geological Survey: Eng, Min. Jour., v. 153, no. 8, pp. 82-83, 1952. (TEI-217)

53. Kaiser, $E_{*} P$, and Page, $I, R_{,}$, Distribution of uranium deposits in the United States (abs.): Geol.Soc. Am. Bull., v.62, no. 12, pt.2, p. 1537, 1951. (part of TEI-168) 
54. King, $R, U$. and Moore, $F, B$, Pitchblende deposits in the United States (abs.): Geol. Soc. Am. Bull., v. 62, no. 12, pt. 2, p. 1537. 1951. (part of TEI-168) :

55. King, Robert U., Moore, F, B, and Leonard, B, F, Uranium in metalmining districts of Colorado (abs.): Geol. Soc. Am. BuIl, v, 63, no. 12, pt. 2, p. 1335, 1952. (TEI-173)

56. Koschmann, A, Ho, Relation of the work of the Geologic Division, $U_{0}$, Geological Survey, to the mining industry in Colorado: Mining Yearbook, Colo. Mining Assoc., Denver, Colo, pp. 33=36, 1951.

57. Krauskopf, Konrad $B_{0}$, Control of trace element concentrations in sea water (abs.): Geol. Soc. Am. Bull, v。63, no. 12, pt. 2, p. 1336, 1952.

58. Kumme1, Bernhard, Triassic stratigraphy of the area around the Green River Basin, Wyoming: Wyoming Geol. Assn. Guidebook, pp. 28=36, 1950.

59. Larsen, Esper $\mathrm{S}_{0}, \mathrm{Jr}_{\mathrm{r}}$, Fletcher, $\mathrm{M}_{*} \mathrm{H}_{0}$, and Cisney, $\mathrm{E}_{*} \mathrm{~A}_{*}$, Strontian apatite: $\mathrm{Am}$. Mineralogist, v. 37, nos. 7 and 8, pp. 656.659, 1952.

60. Larsen, Esper $\mathrm{S}_{*}, \mathrm{~J} \mathrm{r}_{0}, \mathrm{Keevil}, \mathrm{N}_{*} \mathrm{~B}_{\mathrm{a}}$, and Harrison, $\mathrm{H}_{0} \mathrm{C}$, , A method of determining the age of igneous rocks using the accessory minerals: Geol. Soc. Am. Bull, v. 63, no, 10, pp, 1045-1052, 1952.

61. Larsen, Esper S., Jr., Waring, C. I., and Berman, Jo, Zoned zircon from Oklahoma: $\mathrm{Am}$. Mineralogist, v, 38, nos, 11 and 12, pp. 1118= 1125, 1953.

62. Leonard, $B, F_{0}$, Relation of pitchblende deposits to hypogene zoning in the Front Range mineral belt, Colorado (abs.): Geol. Soc. Am。 Bu11., v. 63, no, 12, pt. 2, g. 1274, 1952.

63. McKee, $E_{*}, D_{0}$ and Weir, Gordon $W_{*}$ Terminology for stratification and crosswstratification in sedimentary rock: Geol. Soc. Am, Bull. ข. 64, no. $4, \mathrm{pp} .381=390,1953 .($ TEI $=269)$

64. McKelvey, V, E, Geological studies of the western phosphate field: Am. Inst, Min. Met, Eng, Mining Trans, v. 184, pp。270-279, 1949.

65. McKelvey, $V . E_{0}$, Cathcart, J。 Bo, Altschuler, $Z_{0} S_{0}$, Swanson, $R, W_{0}$, and Lutz, $K_{0}$, Domestic phosphate deposits: in Soil and fertilizer phosphorus in crop nutrition, $v$. IV of Agronomy, Academic Press, pp. 347 -376, 1953. (TEI-271)

66. McKelvey, $V_{0} E_{0}$ and Nelson, J. M. , Characteristics of marine uraniumbearing sedimentary rocks: Econ. Geology, v。 45, no. I, pp. 35-53, 1950. 
67. McKelvey, V. E., Page, I. R., Fischer, R, $P_{0}$, and Butler, A, $P_{0}, J r$, Uranium deposits in the United States (abs.): Econ. Geology, v. 47, no. 1, p. 125, 1952 .

68. Mackin, J. Hoover and Schmidt, Dwight Lo, Placer deposits of radioactive minerals in Valley County, Idaho (abs.): Geol. Soc. Am. Bull., v. 64, no. 12, pt. 2, p. 1549, 1953. (TEM-602)

69. Meyrowitz, R., A new series of immersion liquids: Am. Mineralogist, v. 37, nos. 9 and 10 , pp. 853=856, 1952. (ITM-335)

70. Meyrowitz, Ro and Larsen, E. S., Jr., Immersion liquids of high refractive index: Am. Mineralogist, $v, 36$, nos. 9 and 10, pp. 746 . 750, 1951; (abs.): Geol. Soc. Am, Bull., v。6I, no, 12, pt. 2, p. 1486,1950 。

71. Milkey, R. Go, A theoretical treatment of the absorption characteristics of the dithizone mixed-color system: Anal. Chemistry, v. 24, no. 10, pp. 1675-1676, 1952. (TEI-236)

72. Moore, F. B, and Cavender, W. S. The pitchblende deposit at the Caribou mine, Boulder, Colorado (abs.): Geol. Soc. Am. Bull., v. 63, no. 12, pt. 2, p. 1281, 1952.

73. Mullens, T. E. and Freeman, V. I., A lithofacies study of the Salt Wash sandstone member of the Morrison formation (abs.): Geol. Soc. Am. Bul1., v. 63, no. 12, pt. 2, p. 1340, 1952. (TEI-341)

74. Murata, K, Jo, Cisney, E。A, Stieff, $I_{0} R_{0}$, and Zworykin, E. V., Hydration and base-exchange properties of carnotite, tyuyamunite, and related compounds (abs.): Geol.Soc.Am. Bull., v. 61, no. 12, pt. 2, p. 1489, 1950. (TEI-107)

75. Olson, J. C., Feldspar and associated pegmatite minerals in New Hampshire: Part 14 of a Mineral Resource Survey, N.H. State Planning and Development Commission, 1950.

76. Olson, J. C. and Sharg, W. N, , Geologic setting of the Mountain Pass bastnaesite deposits, San Bernardino County, California (abs.): Geol. Soc, Am. Bull., v。 62, no, 12, pt. 2, p. 1467, 1951.

77. Page, L. Ro, Beryllium in Colorado: The 1950 Mining Yearbook, Colorado Mining Assoc., Denver, Colo., pp. 37-39. (TEI-88).

78. Page, I. R., Uranium in pegmatites: Econ. Geology, v. 45, no. 1, pp. $12-34,1950$.

79. Phair, George and Levine, Harry, Notes on the differential leaching of uranium, radium, and lead from pitchblende in $\mathrm{B}_{2} \mathrm{SO}_{4}$ solutions: Econ, Geology, v. 48, no. 5, pg. 358-369, 1953; (abs.): Geol. Soc. Am. Bul1., v. 63, no. 12, pt. 2, p. 1290, 1952. (TEI-262) 
80. Phair, George and Shimamoto, Onoda Kiyoka, Hydrothermal uranothorite in fluorite breccias from the Blue Jay mine, Janestom, Boulder County, Colorado: Am, Mineralogist, v. 37, nos. 7 and 8, pp. 659. 666, 1952. (TEI 144 )

81. Pierson, C. T., Burbank, W. S., and Singewald, Q. D., Some uranium occurrences in the central and southwestern parts of the Colorado mineral belt (abs.): Geol. Soc. Am. Bull., v. 63, no. 12, pt. 2, p. $1368,1952$.

82. Rove, 0. No, A review of mining geology, Min. Eng., v. 4, no. 2, pp. $140-143,1952$.

83. Senftle, F. E. Effect of diffusion on the natural isotopic abundance ratios (abs.): Geol. Soc. Am. Bull., v. 64, no. 12, pt.2, p. 1472, 2953.

84. Sharp, $W . N_{0}$ and Cavender, W. S., Thorium deposits of the Lemhi Pass district, Lemhi. County, Idaho, and. Beaverhead County, Montana (abs.): Geol. Soc. Am. Bull, v. 64, no. 12, pt. 2, p. 1555, 1953.

85. Shoemaker, E. M. Collapse origin of the diatremes of the Navajo-Hopi. meservation (abs.): Geol. Soc. Am, Bull., v. 64, no, 12, pt. 2, p. $1514,1953$.

86. Shoemaker, E.M. Internal structure of the Sinbad Valleywischer Valley Salt anticline, Colorado and Utah (abs.): Geo1. Soc. Am. Bull., v. 62, no. 12, pt. 2, p. 1478, 1951.

8\%. Shoemaker, $E_{*}$. and Newman, W. L. Ute Mountains, a laccolithic feature in southwestern Colorado (abs.): Ceol. Soc. Arn. Bull., v. 64, no. 12, pt. 2, p. 1555, 1953.

88. Silverman, S. R., Fuyat, R. Ko, and Weiser, Jo D., Quantitative deter. mination of calcite associated with carbonate bearing apatites: Am. Mineralogist, v. 37 , nos. 3 and 4, pp. 211.222, 1952. (TTI. 118)

89. Sims, P. K. and Phair, George, Some features of the pitchblende deposit at the Copper King mine, Larimer County, Colorado (abs.): Ceol. Soc. Am. Bul1., V. 64, no. 12, pt. 2, pp. 1555-6, 1953. (based on TEI -32.1 )

90. Staatz, M. H. and Bauer, H. I., Jr., Uraniferous fluorspar pipes and. veins in the Thomas Range of Juab County, Utah (abs.): Geol. Soc. Am. Buld., v. 63, no. 12, pt. 2, p. 1371, 1952.

91. Staatz, M. H. and Trites, A. F., Jr., Relation of type of country rock to the shape of granitic pegmatite intrusions (abs.): Geo1. Soc. Am. Buld., v. 61, no. 12, pt. 2, pp. 1505-1506, 1950.

92. Stead, F. W., Airborne radioactivity surveying speeds urenium prosw pecting: Eng. Min. Jour., v. 151, no. 9, pp. 74 . 76,1950 . 
93. Stead, F. W., Equipment for uranium prospecting (abs.): Elec. Engineering, v. 69, no. 3, p. 254, 1950.

94. Stead, F. W., Prospecting for uranium with portable Ceiger Munller equipment: In Report of Upper Peninsula of Michigan Mineral Industries Conference, Michigan College of Mining and Technology, Houghton, Michigan, pp. 27-28, May 6, 1949.

95. Stead, F. W. and Davis, F. J., Development and application of airborne radioactivity surveying (abs.): Econ. Geology, v. 47, no. 1, p. 126,1952 .

96. Stead, F. W., Moxham, $R_{0} M_{0}$, and Davis, F. J., Progress in airborne radioactivity surveying (abs.): Geol. Soc. Am. Bull., v。64, no. 12, pt. 2, p. $1477,1953$.

97. Stern, T. W. and Weeks, $A_{0}$. D, Second occurrence of bayleyite in the United States: Am. Mineralogist, v. 37, nos. 11 and 12, pp. 1058 $=1060,1952 . \quad(T E I=243)$

98. Stieff, I. R, and Stern, T. W., The identification and leadwuranium ratio ages of massive uraninites from the Shinarump conglomerate, Utah: Science, v. 115, pg. 706.708, June 27, 1952: (abs.): Chem. Abstracts, v. 46, no. 17, p. 7943, Sept. 10, 1952. (TEM317)

99. Stieff, I. R. and Stern, T. W., Isotopic composition of lead in lead minerals from the Colorado Plateaus (abs.): Geol. Soc. Am. Bull., v. 64, no. 12, pt. 2, pp. 1478-9, 1953.

100. Stieff, I. R. and Stern, T. W., Lead-uranium ages of some uraninites from Triassic to Jurassic sedimentary rocks of the Colorado Plateau (abs.): Geol. Soc. Am. Bull, v. 63, no. 12, pt. 2, p. 1299, 1952. (TII-322)

101. Stieff, I. R. and Stern, T. W., The preparation of nuclear track plates and stripping films for the study of radioactive minerals: Am. Mineralogist, v. 37, nos. 3 and 4, pp. 184-196, 1952. (TEI-127)

102. Stieff, L. R., Stern, T. W., and Milkey, R, G., A preliminary determination of lead uranium and of some Colorado Plateau uranium ores by the lead-uranium and lead-lead ratio methods (abs.): Econ. Geology, v. 47, no. I, p. 123, 1952.

103. Stokes, W. I., Ceology of the Utah-Colorado salt dome region with emphasis on Gypsum Valley, Colorado: Utah Geol. Soc. Guidebook $3,1948$.

104. Stokes, W. L., Uranium-vanadium deposits of the Thompsons area, Grand County, Utah, with emphasis on the origin of carnotite ores: Utah Geol. and Mineralogical Survey Bul1. 46, Dec. 1952, 51 pp., $\$ 1.00$. 
105. Stugard, Frederick, Jr. Two uranium deposits in sandstone, Washington and Kane Counties, Utah (abs.): Geol. Soc. Am. Bullog v. 63, no. 12, pt. 2, p. 1373, 1952 .

106. Stugard, Frederick, Jr., Wyant, D. Go, and Gude, A. J., 3rd, , Secondary uranium deposits in the United States (abs.): Geol. Soc. Am, Bu11., V. 62, no. 12, pt. 2, p. 1542, 1951, (part of TEI -168$)$

107. Swanson, R, W, Phosphate deposits of Permian age in Montana (abs.): Geol. Soc. Am. Buil., v, 64, no. 12, pt, 2, p. 1556w7, 1953.

108. Swanson, V. E. Uranium in the Chattanooga shale (abs): Geol. Soc, Am. Buil., v. 64, no. 12, pt. 2, p. 1481, 1953.

109. Thurston, $R, H$, and Trites, A. F., Ir., Intrusion brecclas of Majuba Hil1, Nevada (abs.): Geol. Soc. Am. Bu11., v。 63, no. 12, pt.2, p. 1305, 1952.

110. Tittle, C.W. and Faul, Henry, Thermal neutron absorption cross section of silicon: Phys. Rev, v. 80, p.908, 1950.

111. Walkex, George W., Rosamond uranium prospect, Kern County, California: Calif. Div, of Mines Special Report 37, 1953. (TEM-514)

112. Waring, C. I. and AnneII, C. S., A semiquantitative spectrographic method for the analysis of minerals, rocks, and ores: Anal. Chemistry, $\forall, 25$, no. 8, pp. 1174w9, 1953. (TEI-143; -215)

113. Waring, C. I. and Mela, Henry, Jr., Method for the determination of small amounts of rare earths and thorium in phosphate rocks: Anal. Chemistry, vo 25, no. 3, pp. 432.5, 1953. (TEI-239)

114. Waring, C. L, and Worthing, Helen, A spectrographic method for determining trace amounts of lead in zircon and other minerals: Am. Mineralogist, $v, 38$, nos. 9 and 10, pp。827-833, 1953. (TEI- 216)

115. Wayland, $T, E_{0}$, Use of isopachous and related maps in the Florida phosphate district: Min. Eng., v。 3, no, 11, pp.975-979, 1951; Am. Inst. Min. Met。 Eng. Trans. 1951, v。 190, 1952.

116. Weeks, Alice D. Mineralogic studies on the Colorado Plateau (a.bs.): Geol. Soc. Am. Bull., v. 63, no, 12, pt. 2, p. 1309, 1952.

117. Weeks, A. D. , Cisney, E. A., and Sherwood, A. Mo, Hurmerite and montroseite, two new vanadium minerals from Montrose County, Colorado (abs.): Geol. Soc. Am. Bul1., $v .61$, no. 12, pt.2, p. $1513,1920$. 
118. Weeks, A, D., Cisney, E. A., and Sherwood, A. M., Montroseite, a new vanadium oxide from the Colorado Plateaus: Am. Mineralogist, v. 38, nos, 11 and 12, pp. 1235-1241, 1953. (TEI-335)

119. Weeks, A, Do, Thompson, M. E., and Thompson, R。 B., Jr., Mineral associations and types of uranium ores on the Colorado Plateaus (abs.): Geol. Soc. Am. Bull, , v. 64, no. 12, pt. 2, pp. 1489$1490,1953$.

120. Weir, Go Wo, Crossmlamination in the Salt Wash sandstone member of the Morrison formation (abs.): Geol. Soc. Am. Bull., v. 62, no. 12, pt. 2, p. 1514, 1951.

121. Wilmarth, $V \cdot R_{0}$, Uranophane deposit at the Silver Cliff mine near Lusk, Niobrara County, Wyoming (abs.): Geol. Soc. Am. Bull., v. 63, no. 12, pt. 2, p. $1376,1952$.

122. Wilmarth, V. R., Bauer, H. I., Jro, Staatz, M. $H_{0}$, and Wyant, D。 Go, Uranium in fluorite deposits (abs.): Geol. Soc. Am. Bull., v. 62, no. 12, pt. 2, p. 1543, 1951. (part of TEI-168)

123. Wyant, $D_{0} G_{*}$, Beroni, E. $P_{0}$, and Granger, H. C., Some uranium dew posits in sandstone (abs.): Geol. Soc. Am. Bull, , v. 62, no. 12, pt. 2, p. 1544, 1951. (part of TEI-168) 
PART III. FINDING LIST OF STATES, AREAS, AND SUBJECTS

This finding list is based on information derived mostly from the titles of reports as listed, and in some cases where titles are of a general nature, from a cursory review of the reports. This list is not a complete index, but is designed to find subjects of major interest.

If a TE number is given, the reader should look in Part I under the given TEI or TEM number. If any other reference is given, i.e., OF, B, C, etc., look in the appropriate section of Part II.

Aeromagnetic studies

$$
\therefore \mathrm{A}=
$$

Arizona............... TEM-344

Colorado .................... TEM-359

Age determination

By means of accessory minerals ........ J-60

Colonado Plateav. ............ TEI=108, 245, 268, 322, $\mathrm{J}=100, \mathrm{~J}-102$

Methods of andysis used........ TEI-245

San Gabriel anorthosite massif. . . . . . . TEM-709

Shinarump conglomerate . . . . . . . . TEM-317, J-98

Airborne radioactivity surveys. . . . . . . . TEI-83, 87, TEM-314 $\mathrm{J}-92, \mathrm{~J}-96$

Alaska, meters for in light planes. . . . . TEM-323

Arizona, Apache County. ......... TEM-607

California

Kern County ............. TEM-360

Riverside County. ........... TEM 360

San Bernardino County . . . . . . . TEI-380, TEM-360

Development and application......... J-95

Florida...................... TEI-387, TEM-644

Between Sanibel Island and Caladesi Island. . TEM 678

Georgia.............. TEM-644

Liberia ................. TEM 361

Michigan, Marquette County. ........ . TEM-159

New Mexico

McKinley County ........... TEM-161

Valencia County ............ TEM-161

North Carolina, ............ . TEM 673

South Carolina. ............ TEM-673

South Dakota, Custer County . . . . . . . TEMw748 
Airborne radioactivity surveys (cont'd)

Wyoming

Camplel1 County . . . . . . . . TEM-508

Carbon County ................... TEM-606, 743,744,

IEM $-745,746,747$

Crook County。............. TEM-605

Fremont County............... TEM-610

Johnson County. ..................... TEM-508

Sublette County ............ TEM-610

Sweetwater County . . . . . . . TEM-147, 609, 743

Uinta County. ......................6II

Alabama

Jefferson County. . . . . . . . . ... TEM-155

Reconnaissance. $0 . \ldots \ldots$. . . . . . . . . TEI 21, 352

Shale . . ............... TEI- 22, TEM-240 Alaska

Airborne radicactivity survey meters for light

planes . . . . . . . . . . . . TEM-323

Alaska Raliroad . . . . . . . . . . TEM- 330

Alaska Railroad-Iliamna region. . . . . . . TEM-319

Central

Manley-Hot Springs-Rampart district ..... TEI= 54

Medfra quadrangle ............TEI- 75

Eastocentrai

Eagle district。 . . . . .....TEI-195

Fairbanks quadrangle。. . . . . . . . TEI-197

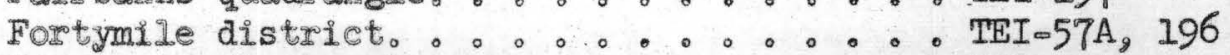

Livengood quadrangle. . ......... TEI-197

Miller HousecCircle Hot Springs area.... TEI-194

Eastern, reconnaissance ........... TEI 292

Fortymile Highway from the Alaska Highway to

Chicken。 . . . . ............ TEM- 329

Gulf of Alaska.

Index to trace elements reports ........ TEM-358

Kobuk River valley, Ruby Creek. ....... TTI-76A

Lower Yukon-Kuskokwim Highlands region. .... TEI-291

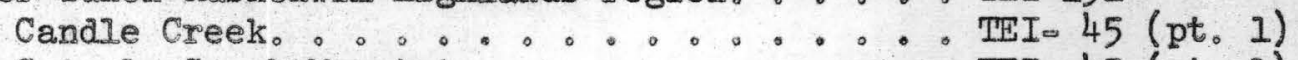

Cripple Creek Mountain. ......... TEI- 45 (pt. 1)

Flat. 0.0 . . . . . . . . . . 46

Julian Creek. . . . . TEI 45 (pt。 1)

Moore Creek ......................... 45 (pt, I)

Mount McKinley。............. TEI $45 \mathrm{C}$

Northeastern

Mount Michelson area. ......... TEI=57C

Upper Porcupine River . ......... TEI 55

Upper Yukon region

Chandalar district。........... TEM-327

Eaglem Nation area............... 56

Wiseman district. 0.0 .0 .0 .0 TEM-327

Northern, Brooks Range. . . . ...... TEM-328 
Alaska (cont'd)

Pegmatites.............. TEI-19I

Phosphate, Brooks Range ....... TTM-328

Placer concentrates ........... TEI-57A

Placer mining ............... TEI- 40

Placers ..................... TEI- 6, 45 (pt. 1),

TEM-326, 327

Reconnaissance。 . . . . . . . TEM 91, 235, 357, 552

Ruby quadrangle ........... TEI-192

Russian Mountains, zeunerite....... TEI-57D

Seward Perinsula. . . . . . . . TEM-322

Brooks Mountain ........... TEI-22I

Candle quadrangle

Buckland-Kiwalik district ...... TEI- 49

Peace River headwaters. ..... TTM-355

Cape Nome area. .......... TEI- 45 (pt. 2)

Darby Mountains district. ........ TEI- 53

Ear Mountain. ........... TEI- 27

Fairhaven district, Candle.Creek.area... . TEI 41

Koyruk district, Sweepstakes Creek area. . . TEI- 25

Lost River area ........... TEI-220

Quartz Creek, South Fork. ..... TEI 42 (pt. 2)

Serpentine-Kougarok ........ TEI 39

South-central district

Southern highway belt ........ TEI 48

Willow Creek mining district. ..... TEI-191

Sortheastern. ............. TEI-293, TEM-32I

Chicagof. . . . . . . . . . TEI-189, TEM-622

Funter Bay。 . . . . . . . . . TEI-189

Goddard Hot Springs ......... . TEI-189

Hyder district. .......... TEI- 73

Juneau. .............. TEIøI89

Ketchikan . . . . . . . . TEI-189

Prince of Wales Is land. . . . . . TEM-356

Southern

Jakolog Bay area. ......... TEI-74A

Yakataga Beach. ........... TTEM-326

Southwestern, Iliamna Lake-Lake Clark region. . TwI-190

Tanana River valley, highways in....... TEI- 38

Tellex area .................... TEI 40

Thorium .............. TEM-339

Upper Copper River valley, highways in. ... TTI- 38

Uppex Yukon division, Lower Coleen River valley . TEI-5TB

Uranothorianite .......... TEM-355

Yentna district, Cache Creek-Upper Peters area. . TEI- 26

Yukon River region

Grant Creek area............. TEI- 42 (pt. 1)

Stevens and Ruby. . . . . . . . TEI-193

Zeunerite . . . . . . TEI-57D, 221

Alluvium, radioactivity of. ......... TEM-225 
Analytical methods and research

Absorption characteristics of the dithizone mixed-color system, theoretical treatment of . . TEI-236

Air concentrator for very low grade ores. . . . TEI-307

Alpha star populations in loaded nuclear

emulsions................ TEI-374

Aromatic compounds of arsenic in chemical analyses ................. TEI-324

Calcite associated with carbonate-bearing apatites, determination. .........TEI-118

Colorimetric determination of total iron with o-phenanthroline ............ TEI-223

Cosmic abundance of nuclear species . . . . . . TEM-3I2 Decomposition of rock and ore samples to be analyzed for very small amounts of $U$ and Th. . . TEI-3IA Effects of destructive distillation of uranium associated with selected carbonaceous subs tances ................... TEI-338 Electric furnace for distillation of oil (from oil shale) ............... TEI-326 Extraction of uranium from aqueous solution

by coal and other materials. ........ TEI-235 Extraction of uranium from coal ........ TEI-372 Fluorimeter

Aluminum in phosphate rock with

8ahydroxyquinoline, determination of ... TEI- 60

Battery powered ........... TEI-135

Critical factors in "direct" determination of uranium ............ T

Direct quantitative method for determination of small amounts of $U$...... TEI- 98

Lignite, determination of $\mathrm{U}$ in....... TEI-153, 153A

Model V transmission fluorimeter...... TEI-I33

Model VI transmission fluorimeter ...... TEI -370 Molybdenum blue reaction, use in determination of phosphorus in waters containing arsenic, silicon, and germanium. ... TEI-379

Monazite, determination of $\mathrm{U}$ in ....... TEI-153, 153A Shale, determination of $\mathrm{U}$ in........ TEI-153, I53A Solutions, for........... TEM-252

Transmission, for determination of $\mathrm{U}_{0}$.... TEI- 9l, 104

Uranium analysis. ........... TTI-219

Uranium in fluoride melts ........ TEI-120

Uranium in nonsaline and saline waters. . . TEI-181

Uranium in phosphate rock ........ TEI-134

Uranium in low grade ores ........ TEI- 47 Hydroxyl substitution in thorite and zircon . . . TEI-327 Multiple conewsplitter for rapid sampling in

the laboratory .............. TEI-37I Noninterference of arsenate ion in volumetric determination of Uusing Jones reductor. . . . TEM-316 
Analytical methods and research (cont'd)

Nuclear track plates and stripping films, preparation of ........... TEI-I27 Phosphorus in vanadiferous rocks....... TEI 99 Photometry, estimation of oil yield of oil shale. TEI 152 Quercetin as colorimetric reagent for zircon. . . OF-c Radiochemistry, Quantitative method for determination of major sources of natural radioactivity. .............. TEI-3I8 Rare earths, determination of small amounts in phosphate rocks .......... TEI-239 Spectrography

Determination of contamination of rock samples, use in............ TrEI- I79 Identification of mineral grains...... TtI-274 Semiquantitative method, analysis of mirera.1s, rocks, ores......... TEI I43, 215

Trace amounts of lead in zircon and other minerals, determination of ......TTI-216 Stability of metallic ions in dilute solutions. . TEI-373 Thorium, determination of

High-grade and low-grade ores, in.... TEI- 44 Naturally occurring material, in. . . . . TEI-3IE Small quantities. ......... TEI- 16

Smali quantities in rocks and minerals... TEI-3ID

Sumary ............ TEI-I78

Use of mesityl oxide。......... TEI 105

Very small percentages......... TEI 15

Uranium, determination of

Elimination of nickel interference by

zine amalgam reductor.......... TEI 23 , 3 IF

Low grade ores, in.......... TTI- 47

Naturally occurring materials, in .....TEI×3IB

Rocks and minerals, in......... TTI-3IC

Small percentages .......... TEI 2

Summary ........... . T TI I I78 Volumetric method, Estimation of oil yield of Apatite oil shale............... TEI 210

New York. .............. TTI-383

Synthesis of, abstracts of literature on. . . . TEI-132 X-ray evidence of nature of carbonatemapatites. . J-2

Arizona (See also Coloraco Plateau) ....... TEI-227 Aeromagnetic studies. .......... TEM-344 Airborne radioactivity surveys, Apache County . . TEM-607 Apache County

Carrizo Mountains ........... TEM-108, 300, C-111 Defiance Uplift, airborne surveys .. . TEMm607 Gamma-ray logging . . . . . . . . TEM-486 Monument Valiey ........... TEI 204 Setsiltso Springs quadrangle $(3,4,5) .$. TEM-402, 404, 439 
Arizona (cont'd)

Carrizo Mountains ............. TEM-196 Aeromagnetic studies.......... TEM- 344 Dinne Mesa NE .............. TEM-423 Dinne Mesa NW ............ TEM-415 Dinne Mesa SE ..................... TEM 424 Dinne Mesa SW....................... TEM 16 Los Gigantes NE .............. TEM-418

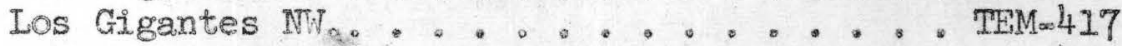
Los Gigantes SF ............... TEM=429 Los Gigantes SW ............... TEM-430 Pastora Peak NE .............. TEM- 425

Pastora Peak NW ........................ T26

Pastora Peak SE ........... TEM-427

Pastora Paak SW...,......... TEM 428

Red Rock Valley NE, ........... TFM- ...420

Red Rock Valley NW. . .......... TEM- 419

Red Rock Valley SE. ............ TEM-421

Red Rock Valley SW............ TEM-422

Chuska Mountains, Morrison formation.......TEM-209

Gammaway Logging, Apache County. ........ TEM-486 Geophysical investigations, Monument Valley . . TFM-577 Gila Cousty, Red Bluff prospect......... TEM=210 Grabam County, Golondrina claims........ TEM-219 Mohave County

Jim Kane mine............... TEM-216

Red HiIIs (Tate) prospect......... TEM=217

Monument \#2 mine............. TEM-646

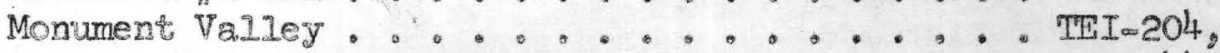
$T E M=344,492,536$

Mitche11 Mesa, geophysical survey ..... . TEM-577 Morrison formation, Chuska Mountains.......TEM-209 Navajo County

Agathla Peak-1 quadrangle......... TEM-44I

Agathla Peak-2 quadrangle ......... TEM-411

Agathla Peak-4 quadrangle ........ TEM-412

Agathla Peak-6 quadrangle ........ TEM-541

Agathla Peak-7 quadrangle ........ TEM-468

Agathla Peak 8 quadrangle ........ TEM=440

Monument Valley ............ TEI $=204$

Shanto Spring-1 quadrangle. ........ TEM-499

Navajoite .......................... . . . . . 393

Pre-Morrison formations ........... TEM-249

Reconnaissance............................. 4 , 21,

Santa Cruz County, White Oak \#1 mine...... TEM-511

Triassic formations............................ 313

Uranium-vanadium ore, potential production. : TEI- 89

Yavapai County, Hillside mine, minerals .... Ju4

Yuma County, Yuma Air Force Base gunnery range. TTM-679 
Arkansas

Newton County, Wm. S. King prospects..... TEM= 18

Reconnaissance。.................. TEI- 9, 21, 34

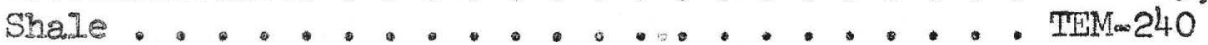
Asphaltites

Kentucky. .............. TEI 43

Pennsylvania. ............... TEI 43

Tennessee ................ TEI 43

West Virginia .............. TEI 43 Asphalts

Association with uranium. ........ TEM-513

Oklahoma................... TEI-298

Base exchange, in uranium minerals. . . . . . TEI-107

Bastnaesite, California................ TEM 35, Jw76, OM-h

Bayleyite............... I $\operatorname{TEI-243}$

Becquerel1te. ............... TEI-309

Beryl ..................... TEM- 72

Colorado, Chaffee County......... TEM 69

Nevada, Elko County, Ruby Mountains ...... OF $-i$.

South Dakota. ............... TEI-226

Beryliium .................... TEI 90, TEM-254

-bearing rocks, non-pegmatitic. ...... TEM- 76

Colorado........................ 88, J-77

Chaffee County, Mount Antero recion . . . TEI-126

Geochemistry. ................ TEI- 29, 3IK, J 050

New Mexico, Luna County, Victorio Mountains . . TEI-166

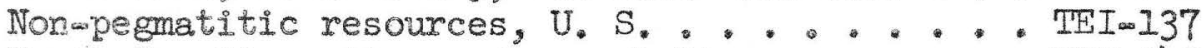

North Carolina, tin spodumene belt. ...... TEI-249

WorId resources ............... TEI I I49

Billietite. ............. TII . . T09

Bone Valley formation, Florida. . . . . . . TEM-237, 436, 507

Mineralogy. ................. TEI I02, 314

Byproduct elements, Phosphoria formation. . . . . . TEI 131 
California

Airborne radioactivity surveys

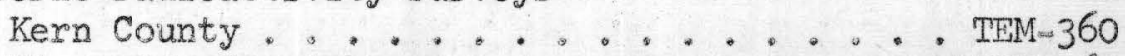

Riverside County. ........... TEM=360

San Bernardino County, Rock Corral area... TEI-380, TEM-360

Autunite.

TEM-136

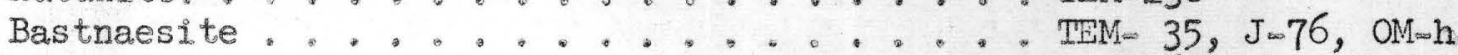

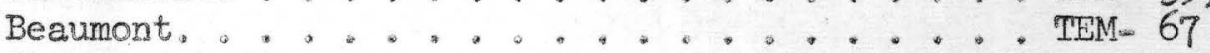

Carbonaceous rocks................ TEI-337, TMM-444

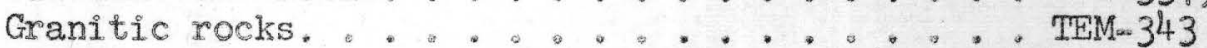

Imperial County ......................... 674

Kern County

Mojave Desert region, airborne surveys. . . TEM-360

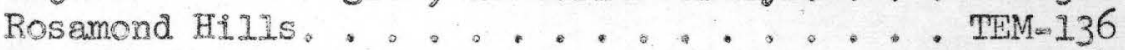

Rosamond uranium prospect...... TEM-514, J-111

Mojave, Jocie Bishop claims.......... TEM 3

Orange County, Costa mesa, Wesley $R$. Collins

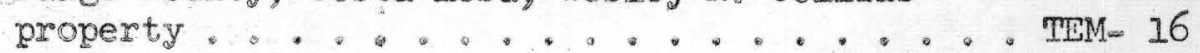

Pegmatites

San Bernardino County, Cady Mountains ... TMM-144

San Diego County. ........... J ... 44

Reconnaissance........................... 21, 24, TEM-554

Riverside County

Beaumont, Marshall ranch, ........ TEM- 15

Joshua Tree National Monument, Live Oak

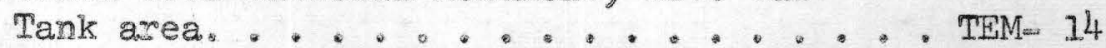

Mojave Desert region, airborne surveys. . . TEM-360

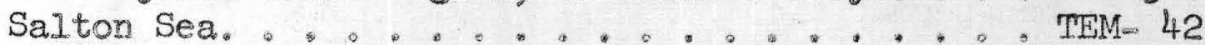

San Bernardino County ....................... OM-h

Birthday claims ....................... 35

Cady Mountains, Hoerner-Ross pegmatite, . TEM-144

Kramer Hills area................. TEM 17

Mojave Desert region, airborne surveys. . . TEM-360

Mountain Pass district. ........ TrI $-251, \mathrm{~J}-76$, OF $-\mathrm{h}$,

Rock Corral area............. TTI-380

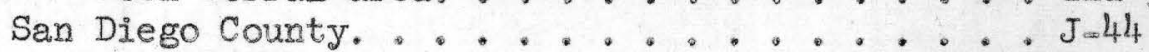

Schmitt-Mitt property ............ TEM 4

Shale .................... TEM-240

Thorium deposits................ TEI-229, 251

Uranium deposits. ..................... TEI-229

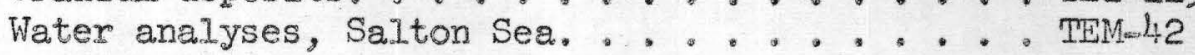

Canada, Great Slave Lake, Iimestone........ THM- 50 
Carbonaceous rocks

California. ............... TET-337, TEM-444

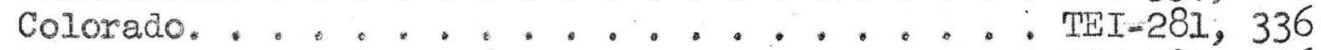

Idaho ....................... TEI-281, 336, TEM-444

Nevada...................... TEI $-337, \mathrm{TEM}-444$

Oregon。.............................. TEI 337, TEM-444

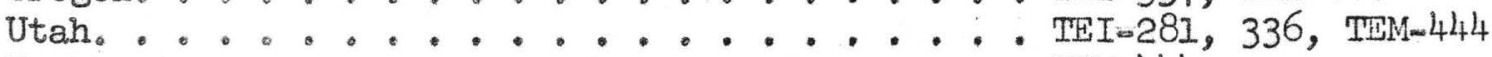

Washington. .................. TEM-444

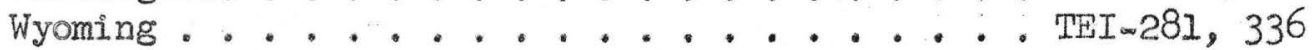

Carbonate apatites, x-ray evidence of nature of : . J-2

Carborne radioactivity surveys. . . . . . . . TEI-65, TEM-88

Carnotite, mineralogy ............. TEM=57, 90

Colorado Plateau. ............. TEM-68

Study of radioactive equilibrium in.... . . TEI-106

Chattanooga shale (See also shales) .. . . . . TEI-22, 58, TMM-63, TEM $=280,333,553$,

TEM-649,

$\mathrm{J}-108$

Experimental adit............. . TEI- 93

Kentucky, ................ TEI-224

Mineralogy, .............. . TEM-474

Origin. ..................... TEI-237

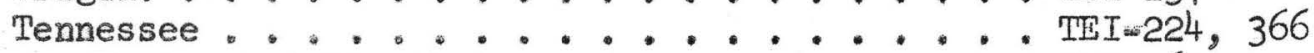

Eastern Highland rim........ TEI- 62

Claim map

Colorado

Mesa County

Calamity Mesa quadrangle....... . TEMw207

Gateway quadrangle. ...... . . TEM 462

Juanita Arch quadrangle .. . . . . . TEM-348

Pine Mountain quadrangle. . . . . . TEM 206

Montrose County

Anderson Mesa quadrangle. ...... TEM-458

Atkinson Creek quadrangle... . . . TEM-266

Bul1 Canyon quadrangle. . . . . . TEM-268, 268 A

Davis Mesa quadrangle ....... TEM-267

Naturita NW quadrangle. ....... TEM=208

Paradox quadrangle........ TEM-345

Red Canyon quadrangle ........ TEM-350

Roc Creek quadrangle. ........ TEM- 349

Uravan quadrangle ......... TEM-347

San Miguel County

Anderson Mesa quadrangle. ...... TEM 458

Bull Canyon quadrangle. . . . . . . TEM-268

Egnar quadrangle. .......... . TEM-456

Gypsum Gap quadrangle ......... TEM-346

Hamm Canyon quadrangle. ....... TEM-351

Horse Range Mesa quadrangle ...... TEM- 463

Joe Davis Hill quadrangle ...... TEM-457

Naturita NW quadrangle. ....... TEM-208 
Clinton formation

Maryland. ................ TEM-434

New Jersey. . . . . . . . . . . . TEM 434

New York. ........................ TEM 434

Coals

Pennsylvania.

Colorado. ..................., J-20

Grand County. .............. TEI-281

Jackson County. ......................... TEI-281

Moffat County ......................... TEI-28I

Rio Blanco County ............ TEI-28I

Routt County................ TEI-28I

Geochemistry. ....................... TEI-389

Idaho, Bonneville County, Fall Creek area . . . TEI-281, TEM-340, 341

Kansas, ...................... TEI- 18

Kentucky. ............................ TE 43, 347

Mineralogy. . . . . . . . . . . . TEI-389

Montana ................. TEM- 446

New Mexico

La Ventana Mesa............. TEI-241, TEM-341

Rio Arriba County ........... TEM-309

Sandoval County .................... TEM-309

North Dakota. . . . . .........., J-20

Oklahome, .......................... TEI- 18

Pennsylvania. ........................ TEI- 43, 348

South Dakota. ................ J-20

Tennessee .......................... TEI 43

Texas ................... J-20

Utah, Uintah County ................ TEI-281

West Virginia.............. TEI 43

Wyoming

Converse County ............... TEM-195

Lincoln County. . . . .......... TEI-281

Sweetwater County, Red Desert....... TEI 332, TEM-341, 601

Extraction of uranium from....... TEI-372

Geochemistry and mineralogy ...... TEI-389

Cobalt analyses, mill sampling program. ...... TEMa 86

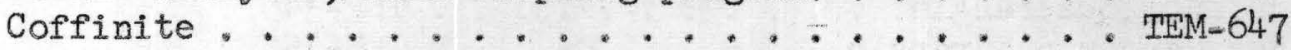

Collapse origin of diatremes in Navajo-Hopi

reservation.

$J \approx 85$

Colorado (See also Colorado Plateau). . . . . J- 81

Aeromagnetic surveys, Uravan Mineral belt . . . TEM-359

Beryl deposits, Chaffee County. ........ TEM= 69

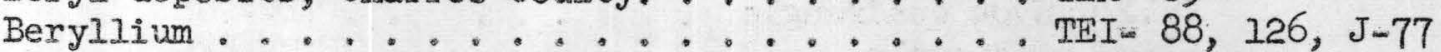

Boulder County. ................. TEI- 21; 173

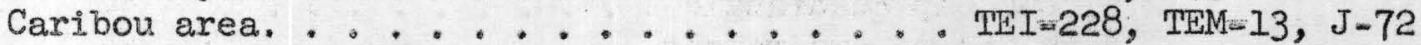

Jamestown district. ........... TEI 4, TEM-1, IA, 25

Blue Jay mine ............ TEI-144, TEM-173

Nederland ......................... TE 4

Wheelman Tunnel ............................ 8

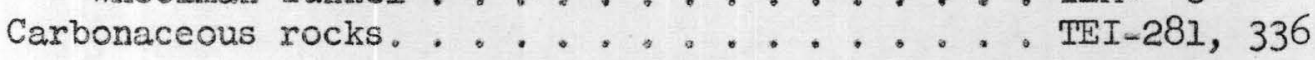


Colorado (cont'd)

Chaffee County

Garfield quadrangle . . . . . . . TTI=255

Mount Antero region, berylilium. ...... TEI-126, TEMw69

Taylor Park quadrangle. . . . . . . TEI-255, TEM 515

Clear Creek County. ........... TEI-173

Central City district ......... TTI 10304

Freeland-Lamartine district . . . . . . TEI-295, J-46

Jo Reynolds mine. .......... TEM- 5

LawsonoDumont district. . . . . . . TEM-153

Jo Reynolds area. ........ TEM-I53

Martha E prospect ......... TEM-291

North Central. . . . . . . . TEI- T05

Robineau claims .......... TEM- 24

Coals ............... J-20, OF $m$

Cretaceous claystones and siltstones, mineralogy. TEI-285

Custer County

Haputa Ranch。 . . . . . . . TEM-285

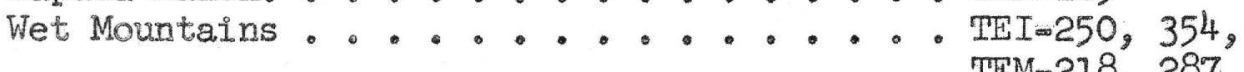

Dolores County

TEM-218, 287

Egnar quadrangle. . . . . . . . TIM-695

Joe Davis Hill quadrangle . . . . . . TEMa T00

Northwestern San Juan Mountains ...... TEM-310

Uravan Mineral belt ..........TEI-109

Aeromagnetic survey........ TEM-359

Verdure-1 quadrangle. ........ TEM-399

Verdure-8 quadrangle. ......... TEM- . 403

Verdure-9 quadrangle. ........ TEM-385

Western San Juan Mountains. ....... TEI-306, TEM-298

Eagle County. ............. THI.173

El Paso County

Colorado Springs, Golden Cycle dump .... TEMia 6

Mike Doyle deposit. ......... TEM-133

Entrada sandstone, western San Juan Mountains . . TEM-298

Fischer Valley-Sinbad Valley anticline.... Jo86

Fluorite. ................. TEI-144, TEM-25, 173

Fremont County, Wet Mountains ....... TEI-250, 354,

TEM- 218,287

Gama-ray logging ........... TTI- 84, TEM-270

Garfield County .............. TEI- 24, 173

Rifle Creek area. ........... OMsa

Geologic guides to carnotite ores ...... TEM-27I

Geophysical investigations

Mesa County . . . . . . . . TEI- 66

Montrose County, Paradox district .... TEMes578

Gilpin County ............. TEI- 21, 173, TEM-512

Apex claims (Bates Creek) : : . TEM- 22

Central City district......... TEI- 4, 125, 177, 
Colorado ( cont $\left.^{\prime} \mathrm{d}\right)$

Grand County................... TEI-308

Coal. ............... TEI 281

Ground water studies, Morris on formation. .. . TEI=161, TEM=137

Gunnison County.............. TEI- 21

Garfield quadrangle ......... TEI-255, TEM-515

Northwestern San Juan Mountains ....... TEM-310

Parlin................ TEI 4

Powderhorn district .......... TEI-353

Quartz Creek pegmatite district...... TEI 138

Taylor Park quadrangle.......... TEI-255,

TEM -515

Jackson County, coal. ............ TEI 281

Jefferson County. ............. TEI

Cook property ............. TEM -20

21, 173

Golden Gate Canyon。 ... ........ TEM-154

Leyden prospect............ TEM 132

Old Leyden Corl mine. .......... TEMw292, 308

Ralston Creek........... TEM=154

Jurassic elaystones and siltstones, mineralogy。. TEI-285

Lake County ..................

St. Kevin district. ......... TEI-234

LaPlata County, western San Juan Mountains. . . TEI-306, TEM-298

Laximer County. .............. TEI $=173$

Big Bouldex prospect. ......... TEM-106

B.lack Hawk \#1 claim

Copper King mine. ......... TEM-128A

Copper King shaft ........... TEM 128

Buckhorn mica mine. ........... TEM-104

Crystal Mountain district ......... TEI-139

Hyatt pegmatite .......... TEMw105

Prairie Divide, Copper King mine...... TEI-311

Spaulding-Woodhams prospects........ TEM- 9A

Treasure Hill area. ........... TEM- 9

Mesa County .............. TEI- 21

Beaver Mesa area. . . . . . . . . TEM-727

Blue Mesa ............... TTI I I54,

Calamity group area .......... TEI= 246

Calamity Mesa . . . . . . . . TEM- 79

Gamma ray logging ......... TEI $=84, T E M-270$

Permeability studies, ........ TEM $=270$

Calamity Mesa quadrangle. ........ TEM-207, 693

Gateway district. .......... TEI-283; TEM-271,

TEM $=632, \mathrm{OM}-\mathrm{i}$

Gateway quadrangle.

Geophysical investigations, ...... TEI 66

Ground water studies. .......... TEI-161

Horse Mesa. . . . . . . . . . TEIw165, TEM 299

Juanita Arch quadrangle ........ TEM-348, 701

Maverick group area ........... TEI 117

Moon Mesa............... TEIw165,

Outlaw Mesa .............. TEI-163;

TTM-185, 186, 189, 202,

TEM-258, 295 
Colorado (cont'd)

Mesa County (cont'd)

Pine Mountain quadrangle. . . . . . TEM-206,704

Uravan Mineral belt . . . . . . . . TEI-109, 283,

TEM-271, 359, 632

Mesozoic rocks. ............ J-48

Mining industry in relation to Geological Survey. J-56

Moffat County ..................... TEI 173, 308, TEM-60

Coal. ................ TEI-281

Montezuma County

Aneth-1 quadrangle. . . . . . . . TEM-452

Ute Mountains .......... . TEM . . . 583, J 87

Verdure-9 quadrangle. . . . . . . . TEM-385

Verdure-16 quadrangle . . . . . . . TEM-392

Montrose County ................. TEI-232, TEM-290

Anderson Mesa quadrangle. . . . . . . TEM 458, 690

Atkinson Creek quadrangle ....... TTM-266, 691

Atkinson Mesa......... T2M-265, 274, 498

Atkinson Mesa area. ......... TTI 290, TMM-48I

Bull Canyon quadrangle. . . . . . TIM-268, 268A, 692

Club Mesa............ TEI-147, TEM-1II, 176,

TIM-177, 178, 179, 184, TEM-204, 256, 260, 261,

TEM-296, 495

Davis Mesa quadrangle........ TEMw267, 694

Dolores Bench .......... TEI 214, TEM-262, 263,

TEM-264, 461

Gateway district. .......... TEI-283, TEM-271, 632

Ground water studies. . . . . . . TEI-16I

Gypsum Valley .......... J . I03, OM-j

American Eagle group. . . . . . . TEM-490

Joker area........... TEM- . 626

Pooch group .......... TEM . . . 630

Rambler group ......... . . TEM=576

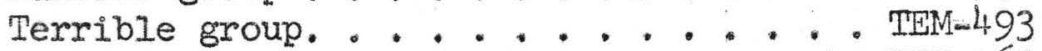

Horse Mesa. . . . . . TTI- 165, TEM-299

Jo Dandy area . . . . . . . . . . TEM-155, 302, 494, 725

Long Park ............. TEM-110, 187, 188, 193,

TEM-201; 297, 581, 686

Moon Mesa........... TEI- 165, TEM-299

Mount Pealewl quadrangle. . . . . . . TEM-467

Mount Peale-8 quadrangle. . . . . . . TEM465

Mount Peale-g quadrangle. ........ TMM

Naturita NW quadrangle. ........ TEM-208, 702

Paradox district. ......... . TEM-459

Geophysical investigations. . . . . TEM -578

Paradox quadrangle. . . . . . . . TEM-345, 703

Red Canyon quadrangle . . . . . . . TEM-350, 705

Roc Creek quadrangle. . . . . . . TEM-349

San Miguel Bench. . . . . . . T TI I 289, TEM-487, 496,

TEM-497, 628 
Colorado $\left(\right.$ cont $\left.^{\prime} \mathrm{d}\right)$

Montrose County (cont'd)

Spring Creek Mesa.

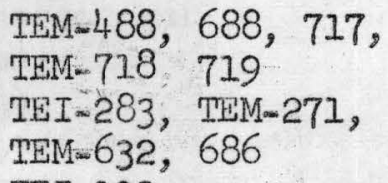

Uravan Mineral belt .......... TEI-109

Aeromagnetic survey ........ TEM-359

Uravan quadrangle ........... TEM-347

Morrison formation............ TEM-251, 270, 324

Ground water studies, ......... . TEM-137

Ouray County, Northwestern San Juan Mountains . TEM-310 Park County

Alma district............... TEI-248

Shirley May (Garo) deposits . . . . . . TEI-277, 299, TEM-222

Pegmatites. .............. . TEI-139, P-227

Larimer County. .......... TTM-105

Permeability studies, Mesa County . . . . TEM-270 Pitchblende

Boulder County, Caribou mine........ J-72

Gilpin County, Central City district,

Quartz Hill............. J-3

Leaching of uranium, radium, and lead from,

in $\mathrm{H}_{2} \mathrm{SO}_{4}$ solutions ........... TEI-262

Pitkin County ............. TEI-173

Radioactive springs ........... TEM 1, IA

Rio Blanco County ............. TTI-173

Coal.................. TEI-281

Routt County. ............... TEI-173, 308

Coal. ............... TEI-281

San Juan County

Northwestern San Juan Mountains . . . . . TEM-310

Western San Juan Mountains. . . . . . TEM-298

San Miguel County

Anderson Mesa quadrangle. ........ TEM 458, 690

Bull Canyon quadrangle. . . . . . . . TEMw268, 692

Charles T area. ........... TT I-112

Egnar quadrangle. ........... TEM- 456,695

Ellison and Burro claims. . . . . . . TEI-115; TEM-683

Georgetown group. ........... TEI-116, TEM-181,

Ground water studies. ......... TEI-161

TEM-182, 625

Gypsum Gap quadrangle ......... . . TEM-346, 697

Gypsum Valley ............. J-103, OM-j

Contact No. 4 claim . . . . . . TEM 455

Early Morn group. . . . . . . . . TEM-623

Long Ridge group. . . . . . . . . TEM-682

Lost Group area ........... TEM-485

Pay Day group . . . . . . . . . TEM-460

Pitchfork group .......... TEM 631

Spectacle Point. . . . . . . . TEM-681

Sunset claim. .......... TEM-574

Tiny clajm. .............. TEM-680 
Colorado (cont'd)

San Miguel County (cont'd)

Hamm Canyon quadrangle.......... TEM-351, 698

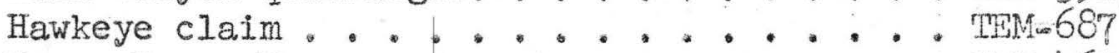

Horse Range Mesa quadrangle... . . TEM-463, 699

Joe Davis Hill quadrangle ........ TEM-457, 700

Legin group crea............ TEI- 164, TRM-113, 171,

TEM $=180,190,391$,

Lower group of claims .......... TET-114

TEM-192, 200, 257, 275

Mount Peale-9 quadrangle. ....... TeM 450

Mount Peale-16 quadrangle ....... TEM 448

Naturita NW quadrangle. ........ TEN 208, 702

Northwestern San Juan Mountains..... THMa 310

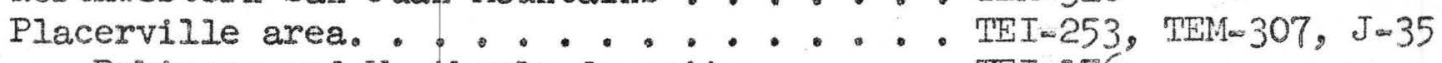

Robinson and Weatherly deposits . . . TEI-176

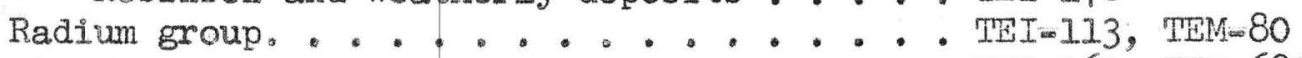

Slick Rock district ........ TrI 162, TEM- 689

South Radium group area... . . . TEM- 685

Spud Patch area......... TEI-286, TEM-112, 259,

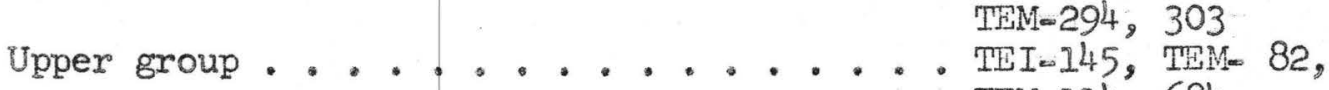

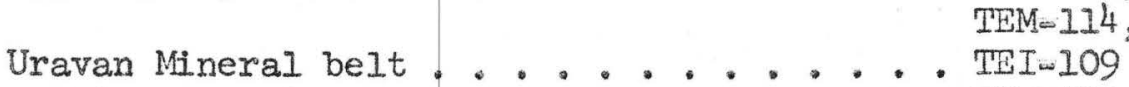

Aeromagnetic survey ...... TEM-359

Vanura claims................... TEM-454

Verdure 1 quadrangle. ........ TEM 399

Western San Juan Mountains. . . . . . TEIm306, TEM-298

Shales.............. TEM-240

Summit County, Montezuma. . . . . . . . TLI-296, TEM-516

Teller County............... TEIw 21

Cripple Creek district. ....... TEI 4

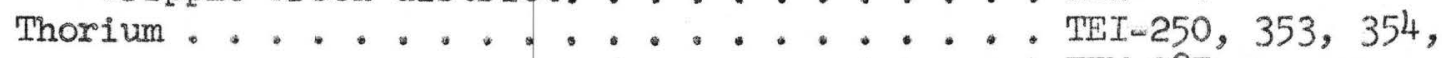

TEM-287

Thucholite, San Miguel County.......... TEM- 307

Torbernite, Clear Creek County. ....... TEM- 24

Uranium vanadium ore, potential production. . . TEI- 89

Uranothorite. ............ . . TEI I I44

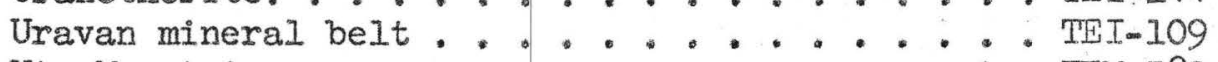

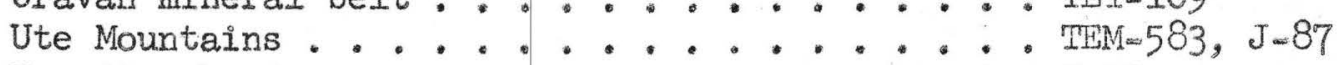

Vanadium-bearing sandstone......... J-32

Vanadium deposits .................... Bas 936

Colorado Front Range (See also Colorado). . . . TIL 59, TEM- 97, 215,

Colorado Plateau (See also Ariz., Colo., N. Mex.,

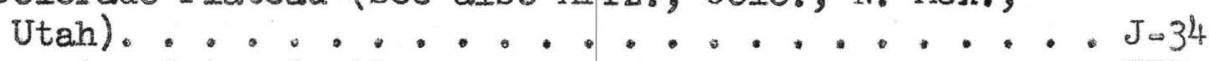

Age determination................ TEI 108, 245, 268, TEI-322, J-100, J-102 
Colorado Plateau (cont'd)

Carnotite ................. TEI 80

Age determination, methods of ....... TEI-108

Geobotanical guides to....... TEI- 96 (pt. 3)

Geologic guides to........... TEI- 86, 96 (pt. 1),

TEI- 119, TEM-101,

TEM-170, 271

Program for study of. ......... TEI- 92

Study of radioactive equilibrium in . . . . TEI-106

Clay studies. .............. TEI $=285, T E M-251,437$

Development drilling program。........ TEM-332, 491

Distribution of ore deposits. ........ TEI-278

Electrical resistivity investigations ...... TEM-232

Geobotanical studies. .......... TEI-160, TEM-199, J-1I

Geologic guides to carnotite ore....... TEI 86,96 (pt, 1),

TEI-119, TEM-101,

TEM-170, 271

Geologic studies............... TEI 110

Geophysical investigations........ TEM-100

Ground water studies.............. TEI-16I,

Isotope geology ............... J-99

Map of uranium region .......... TEI-279

Mi11 capacity for vanadium and uranium ores . . TEM= 37

Mineralogic studies ........... TEI-334, TEM-431,

Carnotite ............. TEM- 68

Montroseite .......... TEI-335

Thermodynamic relations among vanadium

oxides ............. J-40

Uranium ores............ J-119

Morrison formation. ........... TEI 180,341 ,

TEM-324, J-18

Original-state core studies ........ TEM-509

Pre-Morrison formations ............ TEI-328

Production potential of uranium and vanadium

ores................... TEM 37

Recommendations for exploration ....... TEM- 48

Recommendations for geologic studies...... TEM- 38

Recommendations for physical exploration. .... TEM- 38

Recommendations for shift in emphasis of

diamond drilling............. TEM-203

Reserves, accuracy of estimates ....... TEI-288

Silicified tuff, quantity of, in sandstone. . . TEM-716

Spectrographic analyses of rocks and ores . . TEI-278

Sumary of investigations, 1950 ...... TEM-276

Tectonic map. ............ TEM-301

Triassic formations ........... TEI-3I3

Uravan mineral belt ............ TEI-109

Vanadium region ............. OM-b

Geochemistry. ............ TEI-3IJ

Occurrence............... TEI 14 


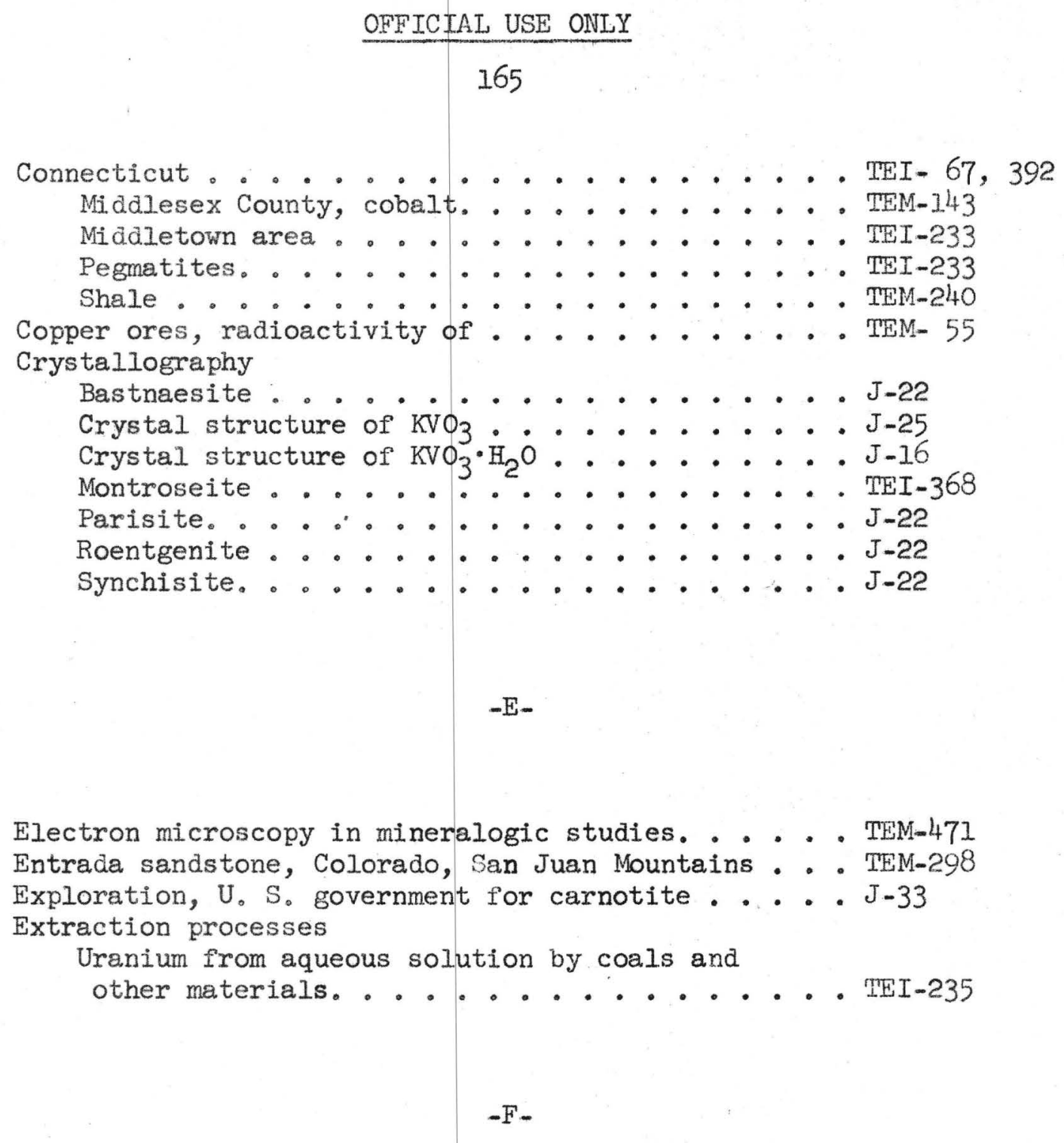

Florida

Airborne radioactivity surveys........ TEI-387, TEM-644

Between Sanibel Island and Caladesi Island. . TEM-678

Aluminum phosphate zone (see Leached Zone)

Bone Valley formation . .......

Chemistry ............. TEI-102

Leached zone. . . . . TEI-102, TEM-436

Mineralogy. ........... . TEI-102, 314

Brewster. . . . . . . . . . . TEM-334

Citrus County, Lowe property. . . . . . . TEM-279

Coarse pebble phosphate deposits....... TEM-315

Fossils, comparison with modern forms ..... TEM-149

Gamma-ray logging ............ TEM-116

Hardee County ............ TEI-141

Hardrock phos phate belt, leached zone ..... TEM-168

Hawthorn formation. . . . . . . . . TEM-337

Hillsborough County ........ . : : TEI-141, TEM-157

Mineralogy。............ TEI-314

Ownership map . . . : : : : : TEM-672

Sydney area .......... TEM-504 


\section{Florida (cont'd)}

Homeland.

Milisite .............. TEI-316, TEM-604

Pseudowave11ite ............ TEI-316, TMM-604

Land-pebble phosphate field........ TEI-79, 94, 95, TEI $=141,212,265$, TEM- $73,83,85$, TEM-138, 157, 172, TEM-243, 253, 289, TEM $334,337,362$, TEM-363, 436, 464, TEM-472, 477, 506, TEM-672, J-13

Bayette area..................... 505

Fort Meade............. TEM- 472

Gamma ray logging ............ TEM-116

Leached zone. ............ TEM-277, 436, J-15

Peace River area. ......... TEI-394, TEM-477

South Pierce area........ . . TEM-505

Varn mine............ . . TEM- 477

Leached zone. . . . . . . . . . TEM-83, 138, 157, 464,

Chemistry .............. TEI-102

Hardrock phosphate belt....... . TEM-168

Hillsborough County .......... TEM-504

Material in overburden dumps. ...... . TEM-277, 477

Mineralogy. ............. TEI-102, TTM-478

Millisite.......................... TEM-604

Pseudowavellite.......... TEI-316, TEM-604

Peace River area. .......... TEI-394

Polk County ...................... 100, 264,

Manatee County...................... TEI-141

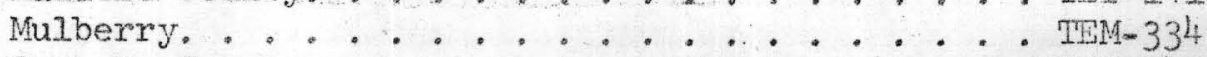

Osceola County. ............... TEI-141

Pasco County. .................. TEI-141

Phosphate (See also land-pebble phosphate field). TEI-79, 85, 94,

TEI- 95, 141, 212,

TEI-387, TEM-44, 46,

TEM- 73, 85, 123,

TEM-138, 230, 231,

TEM-234, 237, 243,

TEM $-253,315,334$,

TEM- 337, 362, 363,

Citrus County........... TEM-279

IEM $-436,506, J-13$

Distribution of uranium in...... . TEI- 85

Phosphate products. ......... TEM-243

Fort Meade............. TEM-472

Gamma-ray logging ........... TEM-116

Hardrock belt, leached zone ....... TEM-168 
Floride (cont'd)

Phosphate (cont'd)

Mineralogy.

Minor metal content . . . . . . TEM-236

Origin and distribution . . . . . . . TII-212

Onnership maps. . . . . . . . . . TEM-672

Petrofraphy ........... TEI-266

Polk County ............ TEM-123, 233

Thorium content . . . . . . . . . TEM- 46

Tonnage and grade of leached zone and

slime ponds............. TEM- 83

Tonnage and grade of slime ponds and

washer debris areas. . . . . . . . TEI- 97

Uranium content of phosphate products . . . TEM-172

Use of isopachous maps in studying. . . . . . J-1.15

Washer plant waste slimes . . . . . . TEM- 98

Polk County.............. . TEI-100, 141, TEM-157

Bonny Lake mine... . . . . . . TEM-123, 230, 231

Clear Springs area. . . . . . . . TEI-264

Gooch, Carlton Helms tract. . . . . . TEM-130

Hamilton tract. . . . . . . . . TEM-233

Homeland area.......... . TEI-264

Ownership map ......... . . TEM-672

Reconnaissance. . . . . . . . . TEI- 17, 21, 352

Shale . . . . . . . . . . . TEM-240

Wavellite . . . . . . . . . TEM-507

Fluorapatite, system of equilibria. . . . . TEI-385

Fluorimeter (See analytical methods)

Fluorite

Colorado, Boulder County, Jamestown district. . . TEI-144,
Formation in sedimentary rocks. . . . . TEI-386

Formation in sedimentary rocks....... . . TEI-386
Missouri, Ste. Genevieve County.. .28

System of equilibria. . . . . . . . . TEI-385

United States... . . . . . . . . TEI-168

Utah. . . . . . . . . . . TEI-136, TEM-54

Juab County, Thomas Range .. . . . TEM-167, 534, J-90

Fluorspar

New Mexico, Grant County. . . . . . . . TEM-120

Utah. . . . . . . . . . . TEI- 50, 252 
Gadolinirm, geochemistry. ........... TEI-128

Gallium, geochemistry ............. TEI 37

Gamma ray logging ............... TEM-52,

Arizona, Apache County, Northwestern Carrizo

Mountains. . ........... TEMa486

Barnaby ....................... TEM 92

Colorado, Mesa County, Calamity Mesa......TEI 84,

Florida, land-pebble phosphate field. . . . TEMa116

TEM-270

Instruments for .............. TEM-311

New Mexico, Grant County, Black Hawk district,

White Signal district.......... TEM 675

0il wells, discovery of radioactive ore ..... TEI 82

Techniques................. TEM-311

Theory of ................. TEM-306

Use of in semiquantitative determination of

uranium and in stratigraphic correlation . . . TEIo 87

Utah, San Juan County, Northwestern Carrizo

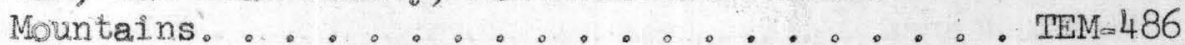

Gamma rays, distribution in dril1 holes...... TEM=135

Geobotanical studies

Carnotite ores, guides to .......... TEI. 96 (pt. 3)

Colorado Plateau. ....................... 96 (pt. 3), 160, TEN. 199, J-11

New Mexico

McKinley County........... TEM-580

Grants. . ........... TEM-272

Haystack Butte. .......... TEM=670

Sandoval County, La Ventana Mesa...... TEMa575, 711

Valencia County ............ TEM-580

South Dakota, Fa.11 River County, Craven Canyon. . TEM-163

Utah, Grand County, Yellow Cat district . . . TEM-273, 579

Piute County. ............ TEM- 483

Temple Mountain district. ....... TEM-482

Wayne County, Capitol Reef area...... TEM-643

Wyoming, Sweetwater County......... TEM-484

Geochemistry. ............... J- ... 36

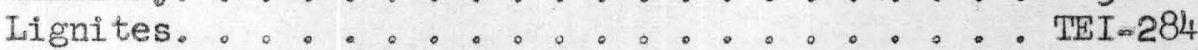

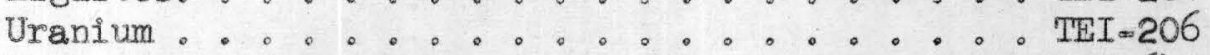

Utah, Wayne County.....................

Geologic guides to carnotite ores, Colorado Plateau. TEI- 86, 96 (pt. 1), TEI-119, TEM=101, TEM $=170,271$

Geophysical investigations

Arizona, Monument Valley, Mitchell Mesa.... TEM=577

Colorado

Mesa County ............. TEI- 66

Montrose County, Paradox district.....TEM-578 
Geophysical investigations (cont'd)

Colorado Plateau. .. . . . . . . . . . TEM-100, 232

Electrical resistivity studies, Colorado Plateau. TEM-232

New Mexico, McKinley County, Grants district. . . TEI-244

Utah

\section{San Juan County}

Happy Jack mine . . . . . . . . ThM-710

White Canyon district, Deerflat... . TwM-627

Georgia

Airborne radioactivity surveys. ....... TEM 644

Heavy minerals. . . . . . . . . . TEM- 23

Monazite, placers........... TEI-349, TEM-2I

Placers, monazite... . . . . . . . . TEI-349, TEM-2I

Reconnaissance. . . . . . . . . . TEI 12, 21, 352

Germanium, geochemistry ........... TEI-3II

In lignites, effect of ashing temperatures

on volatility.............. TEI-267

Occurrence. .............. TEI- 7

Glossary, thorium and uranium-bearing minerals . . TEI-103

Ground-water studies

Colorado Plateau. . . . . . . . . . TEI-161, TEM- 99, 109

Morrison formation, Colorado Plateau. . . . TEI 161, TEM-137

Southeastern Utah, Morrison formation . . . . TEM-137

Southwestern Colorado, Morrison formation . . . TEM 137

$-\mathrm{H}-$

Hawthorn formation, Florida . . . . . . . TEM-337

Heavy minerals

Florida................. TEM=289

Georgia............... TEM- 23

South Carolina. ............ TEM- 23

Heliumbearing gases. . . . . . . . . . . TEM- 51

$-I$ -

Ianthinite................ TEI-367

Idaho

Beaverhead County, Willis quadrangle NW/ . . . TEI-259

Bonneville County, Fall Creek area. . . . . TEI-281, TEM-340, TEM-341, 555

Carbonaceous rocks.............. TEI-281, 336, TEM-444

Caribou County, Johnson Creek quadrangle. . . . TEI-260 
Idaho (cont'd.)

Cassia County, Goose Creek district . . . . TEI-272, 339,

Centennial Range, phosphate ........ TEI-323

Coal, Bonneville, County, Fall Creek area. . . TEM 340

Conda, phosphate. ........... TEM- 70

Dry Valley quadrangle . . . . . . . . TEI-258

East-central. ............. TEI-140

Granitic rocks. ............ TEM-343

Lemhi County

Lemhi Pass district......... TEI-35I, TEM-560, J-84

Mineral Hill. . . . . . . . . . . TEM-286

Lignite, Cassia County, Coose Creek district. . . TEI-272, 339

Limestone, Bonneville County, Fall Creek area . . TEM-340

Long Valley district, monazite. . . . . . . TEM-473

Lyon quadrangle, $S E \frac{1}{4} \ldots . . . . . . . ~ O F-d$

Monazite

Lemhi County.

Long Valley district. . . . . . . TEM-473

Placers .................. TEM 56, 473

Phosphate, Phosphoria formation....... TEI- 94, 142, 183, 187,

TEI-188, 246, 263, 271,

TEI-323, 364, 365, 376,

TEM- 62, 70, 194, J-64,

OF $-a,-b,-g,-r,-p$

Pitchblende, Shoshone County, Sunshine mine . . TEM- 29

\section{Placer deposits}

Idaho (central)

Long Valley district. . . . . . . . . TEM-473

Monazite. . . . . . TEM- 56, 473

Valley County, Bear Valley district . . . . TEM 602

Placer mining ............. TEM 41

Reconnaissance. ................ TEI 4, 21, 72, 232,

Salmon.

Shale

Bonneville County, Fall Creek area. . . . TEM-340

Cassia County, Goose Creek district. . . . TEI-272

Shoshone County, Sunshine mine, pitchblende . . TEM- 29

Valley County, Bear Valley district . . . . . TEM-602

Placer deposits ........... J-68

\section{Illinois}

Reconnaissance................ TEI- 9, 21, 34

Shale ............... TEM-240

Ilmenite, New Mexico, Sierra County ...... TEM-139

Immersion liquids, index. . . . . . . TEM-335, J-70

Indexes

Alaskan trace elements reports. . . . . . TEM-358

Bibliography of trace elements reports. . . . TEI-200, 301, 400

Numerical list of trace elements reports. . . . TEI-202, 300, 325, 400

Trace elements projects......... TEI-2OI 
Indiana

Reconnaissance............ TEI-2I, 34

Shale................. TEI 1, 64, 240

Indium

Geochemistry. ............. . TEI $31 \mathrm{H}$

Occurrence. ............. TEI- 10

Iowa, shale ................ IEM-240

Isotope geology . . . . . . . . . . . . . TEM- 74

Colorado Plateau. . . . . . . . . . . J J 99

Effect of diffusion on natural isotopic

abundance ratios............. TEI-402, J-83

Thorium and decay products. . . . . . . . TEI-209

Uranium and decay products. . . . . . . TEI-209

Kansas

Coals ................ . . TEI 18

Radioactive sediments ......... TEI- 52

Reconnaissance.............. TEI 21

Shales............... TEI- 18, TEM-240

Southeastern, oil fields. . . . . . . . . TEI-12I

Kentucky

Asphaltites .............. . . TEI 43

Coals................... TEI- 43, 347

Reconnaissance. ............ TEI 21, 34, 352

Shales. . . . . . . . . . . TI I, 22, 43,

TEI- 64, 224, TEM-240

$-\mathrm{L}-$

Leached zone, Florida........... TEI-316, TEM- 83, 138,

Bone Valley formation............ TEI-102, TEM-237, 436

Hardrock phosphate belt.......... . TEM-168

Hillsborough County .. . . . . . . . TEM=157, 504

Material in overburden dumps. . . . . . . TEM-277, 477

Mineralogic studies........... TEM-478

Millisite-pseudowaveilite....... TEI-316, TEM-604

Peace River area. .. . . . . . . . . TEI -394

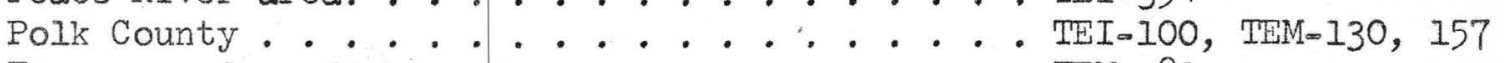

Tonnage and grade............. TEM 83

Leaching, uranium, radium, and lead from pitchblende

in $\mathrm{H}_{2} \mathrm{SO}_{4}$ solutions.............. TEI-262 
Iiberia, airborne radioactivity survey. ...... TEM-361 Limestone

Canada, Great Slave Lake......... TEM- 50

Idaho, Bonneville County, Fall Creek area... TEM 340

United States..................... TEI 168

Iignites

Geochemistry. ............. TEI-284

Germanium in. ............... TEI $=267$

Idaho, Cassia County, Goose Creek district. ... TEI-272, 339, TEM-341

Mineralogy. .............. TEI-284

Montana ........................... 123, TEM=126, 446

Nevada

Churchill County. ........... TEM-226

Elko County, Goose Creek district..... TEI-339

North Dakota.............. TEI-123, TEM-126, 175,

TEM $=341$

Bowman County ..................... TE -238

South Dakota............. TEI-123, TEM-126, 175,

TEM= 341

Harding County............ TEI-238, TEM-342

Perkins County.................... TEI-238

United States .......................... 168

Utah, Boxelder County, Goose Creek district. . TEI-339

Wyoming ...................... TEI-123, TEM-126

Logging of holes, by neutron, gamma method, and

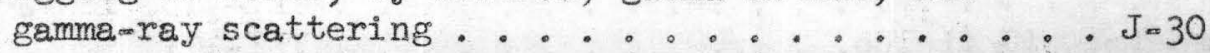

$-\mathrm{M}=$

Magnetic investigations, Utah.

Castle Valley, Round Mountain stock ....... TEI-342

Maine, reconnaissance ............. TEI- 68, 317, 392

Marine sediments (recent), radioactivity. ..... TEM- 49

Maryland, Clinton formation .......... TEMa 434

Massachusetts, reconnaissance ........ TEI 69,392

Measurements of radioactivity, field........ TEI-13

Metamictization

Metamictic disintegration of zircon group .... TEI-369

Studies of metamict minerals

Methods and procedures......... J.8

Michigan

Re-examination of fergusonite......J-9

Airborne radioactivity surveys, Marquette

County ............... TEM-159

Baraga County ............... TEI-303, TEM-74I

Goodrich quartzite.

TEM-558 
Michigan (cont'd)

Keweenawan rocks. . . . . . . . . . IEM= 34

Marquette County

Airborne radioactivity survey . . . . . TEM-159

Palmer area ............. . TEI-384, TEM-558

Monazite, Marquette County, Palmer area... TEI-384, TEM-558

Ontonagon County, White Pine mine...... TEM-158

Pitchblende, Baraga County. ........ . TEI-303

Reconnaissance. ............ . TI 21, TEM-519

Shale .................... TEI. 1, TIM-158, 240

Mill and smelter products............ TEI-242, TEM-40

Mill products program............ TEI-242, TEM-61, 71

Cobalt analyses .......... . TEM- 86

Mineralogy

Arizona, Yavapai County .......... J 4

Bayleyite.............. TEI-243, 309, J-97

Becquerelite............ TEI-309, J-39

Billietite. ........... J-39

Bone Valley formation, Florida. . . . . . . TEI-3I4

Carnotite ........... TEM-57, 90, J-23

Colorado Plateau. . . . . . . . TEM-68

Catalog of radioactive minerals for study. . . TEI-129

Chattanooga shale.......... TEM-474

Claystones and siltstones, Jurassic and.

Cretaceous ............ TTEI-285

Coal, Wyoming, Sweetrater County. . . . . TTE-389

Coffinite ............... TEM-647

Colorado Plateau. . . . . . . . . . ITI-334, TEM-431,

$\mathrm{J}-116,119$

Clay studies. . . . . . . . . . TEM-437

Electron microscopy . . . . . . . . . TEM-471

Hummerite . . . . . . . . . . J-117

Hydration and base exchange properties

carnotite, tyuyamunite, and related compounds. . J-74

Hydroxyl substitution in thorite and zircon . . . J-37

Ianthinite, alteration study. ...... TEI-367

Leached zone, Florida......... TEI-102, TEM-478

Lignites. . . . . . . . . . . . . TEI-284

Millisite, Florida. ......... TEI-3I6, TEM-604

Montroseite . . . . . . . . . J-117, 118

Alteration processes in ....... . J-27

Colorado Plateau. . . . . . . . . TEI-335

Navajoite............ . TEI-393

Phosphate, Florida. . . . . . . . . TEI-266, TEM-89

Phosphate, western field. ......... TEM- 94

Pseudoravelite ........... TTI-316

Quantitative determination of calcite associated

with carbonate-bearing apatites. . . . . . J-88

Roentgenite . . . . . . . . . . J-2I

Sengierite. . . . . . . . . . J-23

Shales. . . . . . . . . . . TEM 95

Strontian apatite......... J-59 
Mineralogy (cont'd)

Thermodynamic relations among vanadium oxides : . Ja40

Thorium-bearing minerals. . . . . . . TEI-103

Tyuyamunite ........... J-23

Uranium-bearing minerals. ......... TEI-103

Wavellite, Florida................ TEM-507, 604

Zeunerite .............. J-38

Zircon, Oklahoma............. J-61

Mine products, sampling program ........ TEI-242

Mine sampling, Florida land pebble phosphate field. . TEM- 85

Mining geology. ............. J-82

Minnesota, reconnaissance .......... TEM-519

Mississippi, reconnaissance ......... TEI-352

Missouri, reconnaissance. .......... TEI $=$ 9, 21, 34

Ste. Genevieve County, Bussen's quarry. . . . TEM 28

Shale .................. TEM-240 Monazite.

Ste. Genevieve County, Bussen's quarry. . . TEM= 28

Georgia .................. TEI-349

Idaho, Lemhi County, Mineral Hill . . . . TEM-286

Long Valley district. ........ TEM 473

Placers ................ TEM 56

Michigan, Marquette County, Palmer area... TEI-384, TEM=558

North Carolina. . . . . . . . . TEI- 32, 349, TEM-502

Placers ............... TEM-248, 283

Placer deposits

Georgia $\ldots \ldots \ldots$ TEI-349, TEM-2

North Carolina. . . . . . TEI- 32,349 ,

South Carolina. . . . . . . . . TEI-349, TEM-21

Virginia. . . . . . . . . . TEI-349, TEM-21

South Carolina............... TEI-349, TEM=502, 539

Placers ............... TEM 248

Virginia................. TEI-349

Montana

Beaverhead County, Brown's Lake area. . . . . TEI-259

Lemhi Pass district .......... TEI-351, J 84

Willis quadrangle

Northwest quarter . . . . . . TEI-259

Southwest quarter . . . . . . . TEI-312

Boulder batholith ........... Jo6

Petrography of northeastern ....... J-7

Cedar Creek ............. OF - . . .

Centennial Range, phosphate ........ TEI-323

Coal................. TEM-446

Daly's spur ................ OF - .

Dell. ..................... OF

Eldridge quadrangle ........... OF $=0$

Granitic rocks. . . . . . . . . TEM-343

Jefferson County, Basin, Comstock claims. . . . TEM-127

Boulder district, Free Enterprise mine. . . TEM-140 


\section{5}

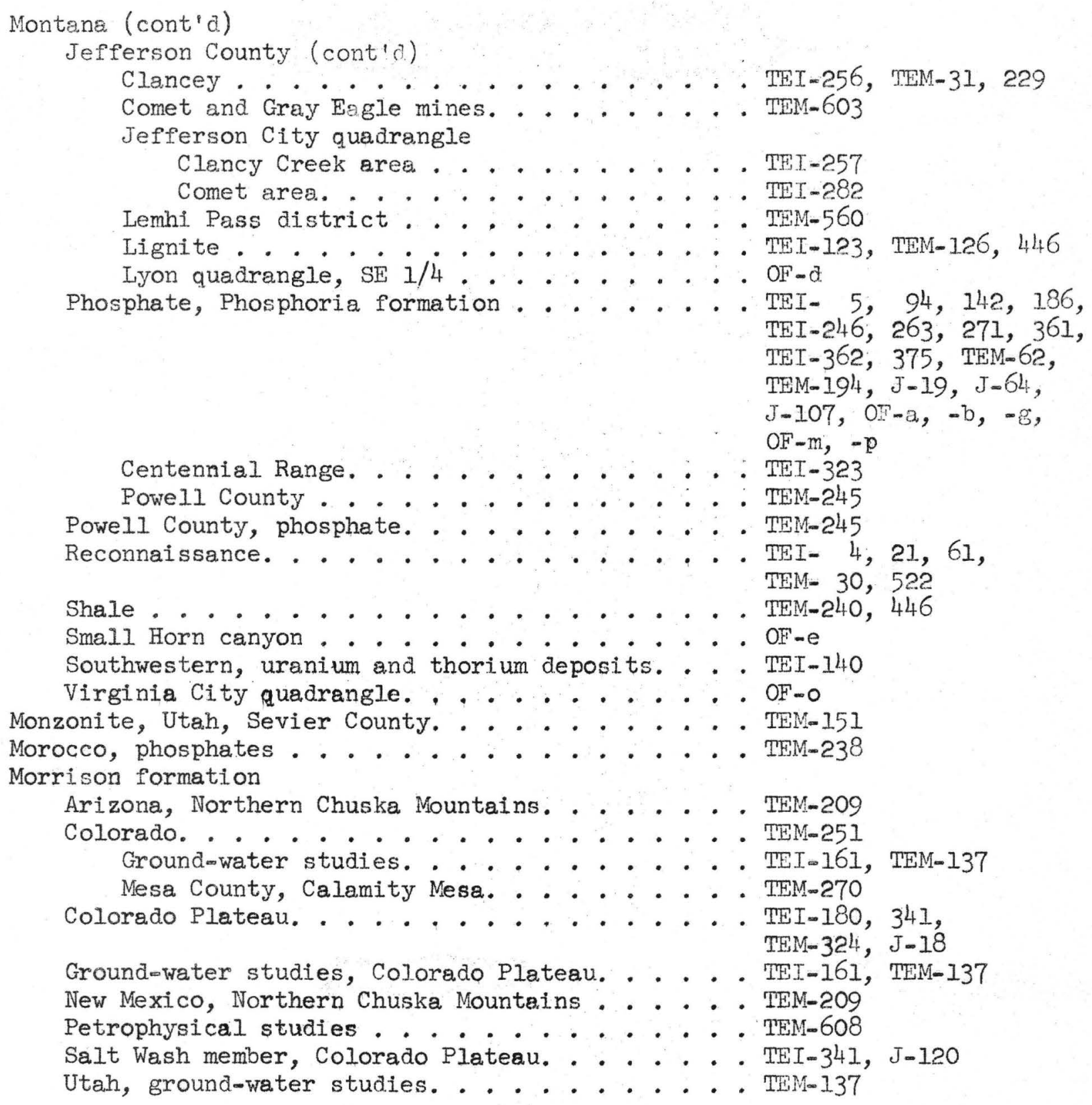




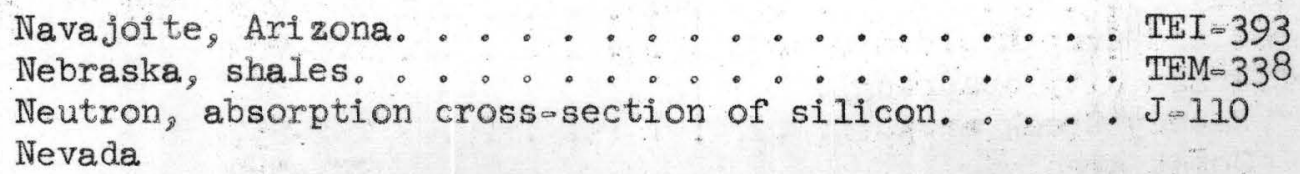

Beryl, Elko County, Ruby Mountains.......: OF $=1$

Carbonaceous rocks. ........... TEI $=337$, TEM- . 444

Churchil1 County, Gamma property. ....... TEM-226

Elko County

Errington-Thiel mine.......... TEI 71

Goose Creek district......... TEI $=339$, TEM-432

Ruby Mountains, beryl......... OF-

Esmeralda County, Coaldale....... TEMa336

Humboldt County, Virgin.Valley district .... TEM-227

Lignite, Elko County, Goose Creek district. . . . TEI-339, TEM-226

Lyon County, East Walker River area...... TEM-228

Yerington property. ........... TEM- 11

Nye County, Round Mountain, Henebergh Tunnel. . TEM= 12

Pershing County

Majuba Hill

Stalin's Present prospect ........ TEM-223

Phosphate, Phosphoria formation ........TEI-263, 271

Reconnaissance. ..................... TEI 4, 9, 21,

Shale........................ TEM-338, 240

Elko County, Goose Creek district... . . TEI-339

New Hampshire . . . . . . . . . . . TEI-392

Pegmatites.................... J 75

Reconnaissance. .................... 67

New Jersey

Clinton formation........... TEM-434

Hunterdon County, Clinton ............ TEI 382

Stockton. ................... TEM-125

Reconnaissance. ...................... TE 317, 392,

Shale . . . . . ...... TEM-240

Torbernite, Hunterdon County, Stockton. . . . TEM-125

New Mexico (See also Colorado Plateau)

Airborne radioactivity survey

McKinley County ............ TEM 161

Valencia County ............ TEM-161

Beryllium ....................... TEI-166

Carrizo Mountains ................. TEM-196

Coal

Rio Arriba County .......... TEM-309

Sandoval County ........... TEM-309

Ia Ventana Mesa ........... TEI-24I

Fluorspar, Grant County ........... TEM=120

Gamma-ray logging, Grant County ........ TEM 675 
New Mexico (cont'd)

Geohntanical studies

McKinley County ............ THM-580

Grants........... . . TEM-272

Haystack Butte. . . . . . . . TEM-670

Sandoval County, Ie Ventana Mesa. . . . TEM-575, 711

Valencia County . . . . . . . . TEM-580

Grant County. ............. . TEI-156

Black Hawk district........ TEI-26I, TEM-118, J-4I

Camma-ray logging, Tyrone..... TEM-675

Black Range.............. . TEM-119

Hines and Langford prospects. . . . . TEM-210

Tunnel Site No. I claim........ TEM-134

White Signal district ........ J-42

Apache Trail prospect . . . . . . TEM-12I

Blue Jay claim. . . . . . . . . TEM-117

Merry Widow claim . . . . . . . TEI-157, TEM-146

Monarch \#2 claim. . . . . . . . TEM-160

Moneymaker claim. ........ . TEM-160

Tyrone, gamma-ray logging ..... TEM-675

Wild Irishman claim....... . . TEM-160

Ilmenite, Sierra County . . . . . . . TEM-139

Lea County. . . . . . . . . . . . . TEM-107

Luna County, Victorio Mountains, beryliium. . . TEI-166 McKinley County

Geobotanical studies. ........ TEM-580

crants

Airborne radioactivity survey .... . TEM-16I

Geobotanical studies. . . . . . . TEM-272

Geophysical investigations. ..... . TEI-244

Haystack Butte, geobotanical studies. . . TEM-670

Mora County, Coyote district........ TEI-338, TEM-556

Guadalupita ........... . . . . . . . . . 435

Morrison formation, Northern Chuska Mountains . TEM-209

Northern Chuska Mountains, Morrison formation . TEM-209

Northwestern, Carrizo Mountains

Pastora Peak NE ......... . TEM-425

Pastora Peak SE .......... . TEM-427

Red Rock Valley NE. .......... TEM-420

Red Rock Valley SE. .......... . TEM-42I

Pitchblende, Grant and Sierra Counties. . . . TEM-119

Pre-Morrison formations ........ TEM-249

Reconnaissance. . . . . . . . . . TEI- 4, 9, 2I,

TEI-174, 198, 232,

TEM-290, 443

Rio Arriba County, black shale, coal. . . . TEM-309

San Juan County, Carrizo Mountains. . . . . TEM-300, C-1II

Sandoval County

Coal. . . . . . . . . . . . . TEM-309

La Ventana Mesa area

Coal........................ TEI-241, TEM-341

Geobotanical studies. . . . . . TEM 575,711

Shale............ TEI-24I, TEM-309, 341 
New Mexico (cont'd)

Shale

Rio Arriba County ........... . TEM-309

Sandoval County ....................... 278, 309

La Ventana Mesa.......... TEI-241

Sierra County

Black Range.............. . TEM-119

Hillsboro mining district, Virginia claim . . TEM०139

Uranium-vanadium ore, potential production. . . . TEI= 89

Valencia County

Airborne radioactivity survey, Grants ... . TEM-161

New York

Geobotanical studies. ........ TEM॰580

Adirondack Mountains........... TEI 70

Apatite ..................... TEI-383

Clinton formation.................. . . . 434

Essex County, Minesville.......... TEI-383

Hudson Valley .............. TEI 70

Reconnaissance. ....................... 21, 67, 317,

TEI-392, TEM-551

Shale ..................... TEI- I, TEM-240

North Carolina

Airborne radioactivity survey ......... TEM-673

Beryllium .............. TEI 249

Monazite............. TIM-502

Placers ................... 32,349 ,

TEM $21,248,283$

Pegmatite .............. TEI 3

Placer deposits, monazite ........ TEI- 32, TEM-283

Reconnaissance. . . . . . . . . . TEI 12, 21, 352

Shale ......................... TEMO

North Dakota

Bowman County, lignite.......... TEI-238

Coals ................... J-20

Lignites. ...................... TEI=123, 238,

Reconnaissance.................... TEI 61

TEM-126, 175, 341

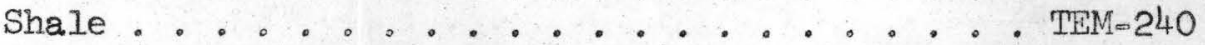


Ohio

Reconnaissance........................ TE 21

Shale ........................... I, 64, TEM-240

Oil fields, radioactivity, in Kansas. . . . . . TEIø121

Oils (crude), associated with uranium ...... TEM॰513

Oklahoma

Coals ....................... TEI 18

Radioactive sediments .......... . TEI 52

Reconnaissance. ............ TEI 9, 21

Shales................ TEI 18, TEM-240

Southwestern, asphaltites ........ TEI-298

Ore distribution studies, Colorado........ TEM-632

Oregono................... TEM-522

Carbonaceous rocks. . . . . . . . . . TEI-337, TEM-444

Granitic rocks. ............ TEM=343

Reconnaissance. ........... TEI 21, 24

Oremlead, nature of ................ Jol2

Origin of uranium, effect of volcanic debris on.. . TEI-170

Original-state core studies, Colorado Plateau . . . TEM-509

Pegmatites. .................. Ja78

Alaska, south=central ........... TEI=191

California

San Bernardino County, Cady Mountains... TEM $144, J=47$

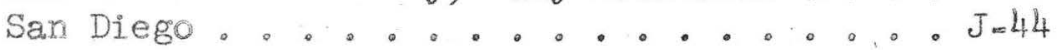

Colorado. ................ TEIo139, P-227

Gunnison County.................. TEI 138

Larimer County. ............ . TEM=105

Connecticut, Middletown area......... TEI-233

New Hampshire ............... J J 75

Nevada, Elko County ........... TEI 71

North Carolina............. TEI 3

South Dakota, Custer County........ THI-155, 225, 226, 231

Utah.................. . . P 227

Wyoming...................... P-227

Pennsylvania.

Asphaltite. ...................... TE43

Carbon County..................... TEM-503

Mauch Chunk ............. TEM॰ 19, 241

Clinton formation.......... TEM- ... 434

Coals......................... TE 43, 348

Reconnaissance..................... TEI 21, 317 ,

TEM=255, 551

Shales....................... TEI $43, \mathrm{TEM}-240$ 
Periodic reports

Quarterly, trace elements progress....... THI-270, 280

Semiannual, trace elements progress . . . . TEI-310, 330, 331, TEI-390, 391

Permeability studies, Colorado, Mesa County . . . TEM-270 Petrography, mineral composition from mineral

grain count................ TEL-273

Petroliferous rocks, association with uranium... TEM-513

Petrology, relation of type of country rock to

shape of granitic pegmatite intrusions ....... . Jm91

Petrophysical studies, Morrison formation. . . . TEM 608 Phosphate

Alaska, Brooks Range........... TEM- 328

Florida........................ 79, 94, 95, 141, TEI-265, 271, TEM-44, TEM $46,73,85,123$, TEM-138, 157, 172, 230, TTEM-231, 234, 243, 253, TEM-315, 334, 337, 362,

Citrus County ............. TEM-279

Distribution.............. TEI-212

Distribution of uranium . . . . . . . TEI 85

Fort Meade.............. TEM-472

Gamma-ray logging ............ TEM-116

Hardrock belt, leached zone . . . . . TEM-168

Mineralogy. ............. TEI-266,

Minor metal content .......... TEM-236

Origin.................... TEI-212

Ownership map . . . . . . . . . . . . . . . .

Polk County ..................... TEM-123,

$T M M=89$

Tonnage and grade of slime ponds and

washer debris areas.......... . TEI- 97

Use of isopachous maps. . . . . . . . Jal15

Washer plant waste slimes...... . TEM- 98 Mineralogy

Florida ............. . . TEM- 89

Northwest phosphate field....... TEM- 94

Minor metal content, Florida............ TEM-236

Morocco ................. TEM-238

Nevada, Phosphoria formation....... TEI-263, 271

Northwestern phosphate field. . . . . . TEM- 94

Phosphoria formation............ . TEI- . . 111

Byproduct elements, potential . ..... TEI-13I

Distribution of uranium in. ....... TEI-275

Idaho...................... TEI, 142, 183, 187, TEI-188, 246, 263, 271, TEI $-323,364,365,376$, TEM- $62,70,194$, $\mathrm{J}-64, \mathrm{OF}-\mathrm{a},-\mathrm{b},-\mathrm{g},-\mathrm{m}$, $\mathrm{OF}-\mathrm{p}$ 
Phosphate (cont'd)

Phosphoria formation (cont'd)

Montana

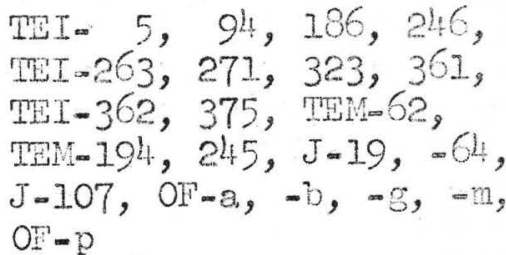

Rare earthe in.............. . TEM-194

Relation of uranium and phosphate . . . . TEI- 77

Utah. ............................ 94, 142, 185, 246,

TEI-263, 271, 360,

TEM $62,194, \mathrm{~J}-64$,

$\mathrm{OF} \approx \mathrm{a},-\mathrm{m},-\mathrm{p}$

Wyoming.......................... 94, 142, 184, 246,

TEI-263, 271, 363, 377,

TET-378, TEM-62, 194, $J=64, O F-a,-b,-8,-m$, $\mathrm{OF}-\mathrm{p}$

South Carolina, Charleston County . . . . . TEM-246

Synthesis of, abstracts of literature on. . . . TEI 132

Tennessee............... . TEI-271

Thorium content, Florida. . . . . . . . THM 46

Uranium in rich phosphate beds, Phosphoria

formation................. TEI I42

Western United States . . . . . . . . . . MII- 64

Sampling and mill studies . . . . . . . IEM- 65

Photogeologic maps (according to quadrangle)

Agatrla Peak-1 quadrangle. . . . . . . . . . TEM-44I

Agathla Peak-2 quadrangle. . . . . . . . . TEM-4II

Agathla Peaken quadrangle. . . . . . . . TEM-412

Agathla Peal-6 quadrangle. . . . . . . . . TEl-54

Agethla Peak-7 quadrangle. . . . . . . . . . TEM-468

Agathla Peak-8 quadrangle. ........... TMM440

Aneth-I anc Aneth-2 quadrangles. . . . . . TEM-452 and 364

Aneth-3 quadrangle ........... TH1-365

Aneth 4 quadrangle .. . ......... TEM-366

Anethw quadrangle .. ........... . . TEM-393

Aneth-6 quadrangle............. . . TEM-400

Anethor quadrangle ............. . . THM-367

Aneth-8 quadrangle.............. . . . . . . . .

Bluff 1 quadrangle............ . . TEl-369

Bluff 8 quadrangle ............ . . TEM-370

Bluf-13 quadrangle. ............ . TEM-371

Blufe 14 quadrangle. . ............ TEM-401

Carlisle-1 quadrangle. . . . . . . . . . THW-372

Carlisle-2 quarrangle. . . . . . . . . . . MEM-667

Carlisle-3 quarangle. . . . . . . . . . IEM-592

Carlisle- 4 quaorangle. . . . . . . . . . TMM-547

Carlisle-5 quadrangle. . . . . . . . . . TEM 544

Carlisle-6 quadrangle. . . . . . . . . . MT-587

Carlisle-8 quadrangle. . . . . . . . . . THM-373 
Photogeologic maps (according to quadrangle) (cont'd) Carlisle- (cont'd)

Carlisleog quadrangle. . . . ....... TEM-374

Carlisle-10 quadrangle ........... TEM-669

Carlisle-15 quadrangle ......... TEM- . 668

Carlisle-16 quadrangle . . . . . . . . TEM-375

Circle Cliffs-l quadrangle ......... TEM-586

Circle Cliffs-2 quadrangle ......... TEM-548

Circle Cliffs-3 quadrangle ......... TEM-549

Circle Cliffs-4 quadrangle .......... TEM-634

Circle Cliffs 5 quadrangle ......... TEM-635

Circle Cliffs 6 quadrangle .......... TEMo585

Circle Cliffs-7 quadrangle .......... TEM-590

Circle Cliffs -8 quadrangle ......... TEM-595

Circle Cliffs-9 quadrangle .......... TEM-529

Circle Cliffs-10 quadrangle. ........ . TEM-531

Circle Cliffsoll quadrangle. . . . . . TEM-636

Circle Cliffs-14 quadrangle......... TEM-637

Circle Cliffs 15 quadrangle.......... TEM-641

Circle Cliffs-16 quadrangle. . . . . . . TEM-614

Clay Hills-12 quadrangle . . . . . . . . TEM-413

Clay Hills-13 quadrangle . . . . . . . . TEM-409

Clay Hills-14 quadrangle . . . . . . . TEM 442

Clay Hillsw15 quadrangle . . . . . . . . TEMo414

Clay Hills-16 quadrangle . . . . . . . TEM 449

Desert Lake-9 quadrangle .......... TEM-737

Desert Lake-11 quadrangle.......... TEM-658

Desert Lake-14 quadrangle. ......... TEM-651

Elk Ridge-l quadrangle ........... . TEM-410

Elk Ridge-8 quadrangle . . . . . . . . . TEM⿻407

Elk Ridge-9 quadrangle . . . . . . . . . TEM 453

Elk Ridge-12 quadrangle. . . . . . . . . TEM-396

Elk Ridge-13 quadrangle. . . . . . . . TEM-376

Elk Ridge-16 quadrangle. . . . . ........ TEM-377

Emery-1 quadrangle . .......... TEM-591

Emery 8 quadrangle ............ TEM-593

Emeryo9 quadrangle .......... TEM-588

Emery-16 quadrangle. . . . . . . . . TEM-546

Kaiparowits Peak 8 quadrangle. ....... TEM-661

Kaiparowits Peak-9 quadrangle. . . . . . . TEM-663

Moab-10 quadrangle ........... . TEM-616

Moab-1l quadrangle . . . . ....... TEM-652

Moab-12 quadrangle .......... TEM-639

Moab-13 quadrangle ............. TEM-731

Moab-14 quadrangle ........... TEME584

Moab-15 quadrangle . . . . . . . . . TEM-598

Mount Peale-1 quadrangle . . . . . . . TEM-467

Mount Peale-4 quadrangle ......... TEMo527

Mount Peale 5 quadrangle . . . . . . . TEM-378

Mount Peale-6 quadrangle ......... TEM-379,

Mount Peale-7 quadrangle ......... TEM-466

Mount Peale 8 quadrangle ......... TEM-465 
Photogeologic maps (according to quadrangle) (cont'd) Mount Peale (cont'd)

Mount Pealea9 quadrangle . . . . . . . . . TEM-450

Mount Peale-10 quadrangle. . . . . . . . . TEM-451

Mount Peale-1l quadrangle. . . . . . . . . . TEM-380, 380A

Mount Peale-12 quadrangle. . . . . . . . TEM=381

Mount Peale-13 quadrangle. . . . . . . . . TIM-398

Mount Peale-14 quadrangle. . . . . . . . . . TFM 382

Mount Peale-15 quadrangle. . . . . . . . . TEMo447

Mount Peale-16 quadrangle. . . . . . . . . TEMa 448

Mount Pennell-5 quadrangle . . . . . . . TEM-596

Mount Pennelloll quadrangle. . . . . . . . TEM 633

Mount Pennell-12 quadrangle. . . . . . . TEM-597

Mount Pennell-13 quadrangle. . . . . . . . TEM-615

Mount Pennell-14 quadrangle. . . . . . . TEM-613

Navajo Mountain-3 quadrangle ........ . TEM-621

Navajo Mountain 4 quadrangle . . . . . . . TIM 619

Navajo Mountain 6 quadrangle . . . . . . . . TEM-620

Navajo Mountain-9 quadrangle . . . . . . . TEM-469

Navajo Mountain-13 quadrangle. . . . . . . . TEM-526

Navajo Mountain-16 quadrangle. . . . . . . . TEM-470

Notom 15 quadrangle. .......... TEM-640

Orange Cliffs-1 quadrangle . . . . . . . . TEM 665

Orange Cliffs-2 quadrangle . . . . . . . . . TEM-600

Orange Cliffs -3 quadrangle . . . . . . . . TEMa594

Orange Cliffs 4 quadrangle . . . . . . . . TEM 664

Orange Cliffs -5 quadrangle ........ . TEM=525

Orange Cliffs 6 quadrangle . . . . . . . TEM-599

Orange Cliffs 7 quadrangle ......... TEM-612

Orange Cliffs 8 quadrangle . . . . . . . . TEMa654

Orange Cliffs -9 quadrangle . . . . . . . . TEM-732

Orange Cliffs-10 quadrangle. . . . . . . . TEM-618

Orange Cliffs-ll quadrangle. . . . . . . . . TEM-523

Orange Cliffs-12 quadrangle. . . . . . . . TIM-524

Orange Cliffs-13 quadrangle. . . . . . . . TFM-500

Orange Cliffs-14 quadrangle. . . . . . . . TEM-501

Orange Cliffs-15 quadrangle. . . . . . . . TEM-653

Setsiltso Springs-3 quadrangle . . . . . . . TEM-402

Setsiltso Springs 4 quadrangle ....... TEM- 404

Setsiltso Springs-5 quadrangle . . . . . . . TEM-439

Shanto Spring-l quadrangle . . . . . . . . TEM-499

Stinking Spring Creek-2 quadrangle . . . . . . TEM-589

Stinking Spring Creek-3 quadrangle ....... TTM-542

Stinking Spring Creekw 4 quadrangle . . . . . . TEM-532

Stinking Spring Creek-5 quadrangle . . . . . . TEM-528

Stinking Spring Creek-6 quadrangle ....... TTM-530

Stinking Spring Creek-7 quadrangle . . . . . . TEM-550

Stinking Spring Creek-8 quadrangle . . . . . . TEM-657

Stinking Spring Creek-9 quadrangle . . . . . . TEM 650

Stinking Spring Creek-10 quadrangle. . . . . TEM-543

Stinking Spring Creek-ll quadrangle. . . . . TEM-383 
Photogeologic maps (according to quadrangle) (cont'd) Stinking Spring Creek- (cont'd)

Stinking Spring Creek-12 quadrangle. ..... TEM-384

Stinking Spring Creek-13 quadrangle. . . . . . TEM-397

Stinking Spring Creek-14 quadrangle. ...... TEM-394

Stinking Spring Creek-15 quadrangle....... TEM-545

Straight Cliffs $m$ quadrangle .........TEM-638

Straight Cliffs-2 quadrangle ........ TEM-662

Tidwell-4 quadrangle .......... TEMa655

Tidwell 5 quadrangle .......... TEM-642

Tidwell-9 quadrangle . . . . . . . . TEM-660

Tidwell-15 quadrangle. . . . . . . . TEM-656

Tidvell-16 quadrangle. .......... TLM-617

Verdure -1 quadrangle .......... TEM-399

Verdure V $^{2}$ quadrangle . . . . . . . . . TEM-406

Verdure -3 quadrangle ........... TEM 433

Verdure -4 quadrangle .......... TEM-438

Verdure -5 quadrangle .......... TEM-408

Verdure-6 quadrangle . . . . . . . . TEM-405

Verdure 7 quadrangle .......... TEM-395

Verdure 8 quadrangle ........... TEM-403

Verdure-9 quadrangle .......... TEM-385

Verdure-10 quadrangle. ......... TEM-386

Verdure-11 quadrangle. ......... TEM- 387

Verdure-12 quadrangle. .......... TEM-388

Verdure-13 quadrangle. ......... TEM-389

Verdure -14 quadrangle. . ......... TEM-390

Verdure-15 quadrangle. .......... TEM-391

Verdure 16 quadrangle. . . . . . . . . TEM-392

Woodside 13 quadrangle .......... TEM-659

Photogeologic maps (according to state and county)

Arizona

Apache County

Setsiltso Springs -3 quadrangle ..... TEM-402

Setsiltso Springs -4 quadrangle ..... TEM=404

Setsiltso Springs $=5$ quadrangle ..... TEMa 439 Navajo County

Agathla Peak-1 quadrangle. ...... TEM-441

Agathla Peak-2 quadrangle. ...... TEM-4II

Agathla Peak 4 quadrangle. . . . . . TEM-412

Agathla Peak-6 quadrangle. . . . . . TEM-541

Agathla Peak 7 quadrangle. . . . . . . TEM-468

Agathla Peak-8 quadrangle. . . . . . TEM-440

Colorado

Shanto Spring I quadrangle . . . . . TEM-499

Dolores County

Verdure 1 quadrangle ........TEM-399

Verdure 8 quadrangle . . . . . . . TEM-403

Verdure $=9$ quadrangle ........ TEM-385 
Photogeologic maps (according to state and county) (cont'd) Colorado (cont'd)

Montezuma County

Anethol quadrangle . . . . . . . TEM-4h52

Verdure-9 quadrangle ........ . TEM-385

Verdure-16 quadrangle. . . . . . . TEM-392 Montrose County

Mount Peale-1 quadrangle . . . . . . TEM-467

Mount Peale-8 quadrangle . . . . . . TMM 465

Mount Pealem9 quadrangle ....... TEM-450

San Miguel County

Mount Peale-9 quadrangle ....... TEM-450

Mount Peale-16 quadrangle. .... TEM 448

Verdure-1 quadrangle . . . . . . . TEM-399

Utah

Emery County

Desert Lake 9 quadrangle . . . . . . TEM-737

Desert Lake-11 quadrangle. . . . . . TEM-658

Desert Lake-14 quadrangle........ TEM-651

Emery-1 quadrangle . . . . . . . TEM-591

Emery-8 quadrangle . . . . . . TEM-593

Emery-9 quadrangle ........ TEM-588

Emery 16 quadrangle. . . . . . . TEM-546

Moab-13 quadrangle ........ TEM-731

Stinking Spring Creek-2 quadrangle ... TEM-589

Stinking Spring Creek-3 quadrangle ... TEM=542

Stinking Spring Creekol quadrangle . . . TEM-532

Stinking Spring Creek-5 quadrangle . . . TEM-528

Stinking Spring Creek 6 quadrangle . . . TEM-530

Stinking Spring Creek-7 quadrangle ... TEM-550

Stinking Spring Creeks8 quadrangle . . . TEM-657

Stinking Spring Creek-9 quadrangle ... TEM-650

Stinking Spring Creeko10 quadrangle... TEM-543

Stinking Spring Creek-11 quadrangle. . . TEM-383

Stinking Spring Creek-12 quadrangle. . . TEM-384

Stinking Spring Creek-13 quadrangle. . . . TEM-397

Stinking Spring Creek-14 quadrangle. . . TEM-394

Stinking Spring Creek-15 quadrangle. . . TEM-545

Tidwello4 quadrangle . . . . . . TEM 655

Tidwell-5 quadrangle ....... TEMa642

Tidwell-9 quadrangle . . . . . . . TEM-660

Tidwell-15 quadrangle. . . . . . . . TEM-656

Tidwell-16 quadrangle. . . . . . . TEM617

Woodside-13 quadrangle ....... TEM-659

Garfield County

Circle Cliffsel quadrangle . . . . . TEM-586

Circle Cliffs-2 quadrangle . . . . . TEM-548

Circle Cliffs-3 quadrangle . . . . . TEM-549

Circle Cliffse 4 quadrangle ..... TEMa634

Circle Cliffs -5 quadrangle ...... TEM-635

Circle Cliffs-6 quadrangle ...... TEM-585

Circle Cliffs-7 quadrangle ...... TEM=590 
Photogeologic maps (according to state and county) (cont'd) Utah ( $\left.\operatorname{cont}^{\mathrm{d}} \mathrm{d}\right)$

Garfield County (cont'd)

Circle Cliffs (cont'd)

Circle Cliffs-8 quadrangle . . . . . TEM-595

Circle Cliffs-9 quadrangle . . . . . . TEM-529

Circle Cliffs-10 quadrangle. ..... TEM-531

Circle Cliffs-11 quadrangle. ..... TEM=636

Circle Cliffs-14 quadrangle. ...... TEM-637

Circle Cliffs-15 quadrangle. ..... TEM-641

Circle Cliffs-16 quadrangle. .....TEM-614

Kaiparowits Peakø8 quadrangle. . . . TEM-661

Kaiparowits Peak -9 quadrangle. . . . : TEM-663

Mount Pennel1-5 quadrangle ....... TEM=596

Mount Pennell-11 quadrangle. ...... TEM-633

Mount Pennel1 - 12 quadrangle. . . . . T TEM=597

Mount Pennel1-13 quadrangle. ..... TEM-615

Mount Penne11-14 quadrangle. ...... TEM-613

Notom-15 quadrangle. ........ TEM-640

Orange Cliffs 9 quadrangle ..... . TEM-732

Orange Cliffs-10 quadrangle. ..... TEM-618

Orange Cliffs-11 quadrangle. ..... TEM-523

Orange Cliffs-12 quadrangle. . . . . TEM-524

Orange Cliffs-13 quadrangle. . . . . TEM 500

Orange Cliffs -14 quadrangle. ..... TEM-501

Orange Cliffs-15 quadrangle...... TEM-653

Grand County

Moab-10 quadrangle .......... TEM-616

Moab-11 quadrangle ............ TMM-652

Moab-12 quadrangle ........... TEM-639

Moab-13 quadrangle ......... TEM-731

Moab-14 quadrangle ..........TEM-584

Moab-15 quadrangle .......... TEM-598

Mount Peale-1 quadrangle . . . . . . TEM 467

Mount Pealew quadrangle ....... TEM-527

Tidwe1l-9 quadrangle ......... TEM=660

Tidwell-16 quadrangle........ TEM-617

Kane County

Circle Cliffs-14 quadrangle. ..... . TEM-637

Circle Cliffs-15 quadrangle. ..... TEM-641

Circle Cliffs-16 quadrangle. . . . . TEM-614

Mount Pennell-13 quadrangle. ..... TEM-615

Mount Pennell-14 quadrangle. ...... TEM=613

Navajo Mountain-3 quadrangle ..... . TEM-621

Navajo Mountaino 4 quadrangle ... . . TEM-619

Navajo Mountain-6 quadrangle... . . TEM=620

Navajo Mountain-13 quadrangle. .. . . TEM-526

Straight Cliffs-1 quadrangle ..... . TEM-638

Straight Cliffs-2 quadrangle .... . . TEM-662 
Photogeologic maps (according to state and county) (cont'd) Utah ( $\left.\operatorname{cost}^{\prime} \bar{a}\right)$

San Juan County

Aneth-1 quadrangle .. . . . . . TEM-452

Aneth-2 quadrangle .. ...... . TEM-364

Aneth-3 quadrangle . . . . . . . TEM-365

Aneth-4 quadrangle . . . . . . . TEM-366

Aneth-5 quadrangle ........ . TEM-393

Aneth-6 quadrangle ........ . . TEM-400

Aneth-7 quadrangle . . . . . . . TEM-367

Aneth-8 quadrangle . . . . . . . . TEM-363

Bluff-1 quadrangle . . . . . . . TEM-369

Bluff-8 quadrangle .. . . . . . . TEM-370

Bluff-13 quadrangle. . . . . . . . TEM-371

Bluff-14 quadrangle. . . . . . . . TEM-401

Carlisle-1 quadrangle. . . . . . . . THM-372

Carlisle-2 quadrangle. . . . . . . . THM-667

Carlisle-3 quadrangle. . . . . . . TEM-592

Carlicle-4 quadrangle. . . . . . . . TEM-547

Carlisle-5 quadrangle. . . . . . . . TEM-544

Carlisle-6 quadrangle. . . . . . . TEM-587

Carlisle-8 quadrangle. . . . . . . TEM-373

Carlisle-9 quadrangle. . . . . . . TEM-374

Carlisle-10 quadrangle. . . . . . . IEM-669

Carlisle-15 quadrangle . . . . . . . TEM-668

Carlisle-16 quadrangle . . . . . . TEM-375

Clay Hills-12 quadrangle . . . . . T TM-413

Clay Hills-13 quadrangle... . . . . TEM-409

Clay Hills-14 quadrangle. . . . . . . TEN-442

Clay HjIIs-15 quadrangle. . . . . . TEM-414

Clay Hills-16 quadrangle. . . . . . . TEM-449

Elk Ridge-I quadrangle . . . . . . . . THM-4lo

Elk Ridge-8 quadrangle . . . . . . TEM-407

Elk Ridge-9 quadrangle . . . . . . . TEM-453

E1k Ridge-12 quadrangle. . . . . . . MM-396

Ilk Ridge-13 quadrangle. . . . . . . TEM-376

Elk Ridge-16 quadrangle. . . . . . . TEM-377

Mount Peale-1 quadrangle. . . . . . . MEM-467

Mount Peale-4 quadrangle . . . . . . TEM-527

Mount Peale-5 quadrangle . . . . . TEM-378

Mount Peale-6 quadrangle . . . . . TMM-379, 379A

Mount Peale-7 quadrangle... . . . . TEM-466

Mount Peale-8 quadrangle . . . . . . TEM-465

Mount Peale-9 quadrangle . . . . . . T TM-450

Mount Peale-10 quadrangle. . . . . . THM-451

Mount Peale- Il quadrangle. . . . . . TEM-380, $380 \mathrm{~A}$

Mount Peale-12 quadrangle. . . . . . . TEM-381

Mount Peale-15 quadrangle, , . . . . TEM-447

Mount Peale-16 quadrangle. . . . . . . TEM-448 


\section{8}

Photogeologic maps (according to state and county) ( cont $^{\prime} \mathrm{d}$ ) Utah (cont'd)

San Juan County $\left(\operatorname{cont}^{8} d\right)$

Navajo Mountain=3 quadrangle . . . . . TEM-621

Nava jo Mountain-6 quadrangle..... TEM-620

Navajo Mountain-9 quadrangle ...... TEM-469

Navajo Mountain-13 quadrangle. .... TEM-526

Navajo Mountain-16 quadrangle. . . . TEM-470

Orange Cliffs-l quadrangle . ..... TEM-665

Orange Cliffs $=8$ quadrangle ...... TEM-654

Orange Cliffs-15 quadrangle. ..... TTM-653

Verdure-1 quadrangle . . . . . . . TEM-399

Verdure-2 quadrangle ........ TEM-406

Verdure-3 quadrangle ........ TEM-433

Verdure-4 quadrangle .........TEM-438

Verdure -5 quadrangle ......... TEM-408

Verdure-6 quadrangle ......... TEM-405

Verdure 7 quadrangle ........ TEM-395

Vexdure 8 quadrangle ......... TEM-403

Verdure-9 quadrangle ......... TEM-385

Verdure-10 quadrangle. ....... TEM-386

Verdure-11 quadrangle. . . . . . . . TEM-387

Verdure-12 quadrangle........ TEM-388

Verdure-13 quadrangle. ....... . TEM-389

Verdure-14 quadrangle. ........ TEM-390

Verdure-15 quadrangle......... TEM-391

Verdure-16 quadrangle........... TEM-392 Wayne County

Carlisle-4 quadrangle. ....... . TEM-547

Carlis le-5 quadrangle. ........ TEM- . 544

Mount Peale-13 quadrangle. ...... TEM-398

Mount Peale-14 quadrangle. . . . . . TEM-382

Mount Penne11-14 quadrangle....... TEM-613

Orange Cliffs-1 quadrangle ...... TEM-665

Orange Cliffs-2 quadrangle ...... TEM-600

Orange Cliffs-3 quadrangle ...... TEM-594

Orange Cliffs-4 quadrangle ...... TEM-664

Orange Cliffs -5 quadrangle ....... TEM-525

Orange Cliffs-6 quadrangle ....... TEM-599

Orange Cliffs 7 quadrangle ...... THE-612

Orange Cliffs -8 quadrangle ...... TEM-654

Orange Cliffs-9 quadrangle ...... TEM-732

Orange Cliffs-10 quadrangle. ..... TEM-618

Orange Cliffs 11 quadrangle...... TEM-523

Orange Cliffs-12 quadrangle. ..... TEM-524 
Photosensitivity, uranium minerals ........ . TEI-107 Pitchblende

Colorado

Boulder County, Caribou mine ....... Jo72

Gilpin County, Central City district.... TEI-177, 247, $T E M=198, J-3$

Idaho, Shoshone County, Sunshine mine...... TEM- 29

Michigan, Baraga County............. TEI $=303$

New Mexico, Grant and Sierra Counties...... TEMo119

United States............... TEI-168

Placer concentrates, Alaska, Fortymile district. . . TEIo 57A

Placer mining

Alaska .......................... TEI 40

Idaho. ............................ 4 I

Placers

Alaska ..................... 6, 45 (pt. 1), TEM $-326,327$

Idaho (central).................... TEI 19

Monazite ....................... 56, 473, 602, $\mathrm{J}=68$

Monazite

Georgia.。. ............. TEM 21

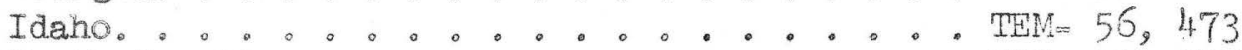

North Carolina......................... 32, TEM-21, 248 $T E M=283$

South Carolina.............. TEM- 21, 243

Virginia。.。. ............ TIM- 21

Pleistocene terrace deposits

Georgia................. TEM 23

South Carolina.............. TEM= 23

Pre-Morrison formations

Arizona. ................. TEM-249

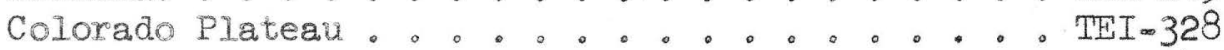

New Mexico......................... 249

Resource appraisal ............. TEI 328

Utah......................... TE-249

Pseudowavelite, Florida........................ 316

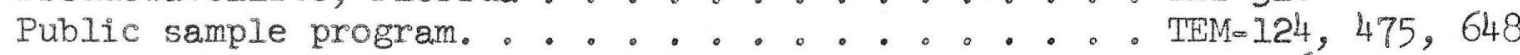

Pyrobitumen deposits, Colorado, San Miguel County. . TEI-176

$-Q=$

Quarterly progress reports, trace elements..... IEI 270, 280 
Radioactive springs, Colorado.......... TEM 1, IA

Radioactive sediments

Kansas ................ TEI- 52

Oklahoma ........................ TEI 52

Radioactivity

Alluvium downstream from uranium deposits. . . . TEI-225

Copper ores, in............. TEM 55

Fresh water.............. TEM- 59

Iron oxides, in......................... TEI6

Recent marine sediments......... TEM- 49, 59

Sea water, in........................ TEM 49

Stream gravels, in...................... TE-629

Radioactivity counting

Errors, control chart method applied to. . . . TEI- 28, 3IG

Radioactivity measurements, field. ....... . TEI- 13

Radioactivity, methods for detection ........ J-28

Equipment. ............ TEI-211, TEM-323, J-93

Ceigerwuller........... Jo94

Modification to Tracerlab automatic

sample changer........... TEM- 142

Ratemeter type 1011......... TEM 84

Scintillation counters........ TEI-403

Measurements of, field....... TEI 13

Radon, Utah, Grand County............. TEM-354

Radon=bearing gas, Amarillo helium district. . . . TEM-131

Radon in natural gas ............ TEM-239, 533

Recent sediments, radioactivity in ........ TEMo 59

Resource appraisal, pre-Morrison formation . . . . TEI-328

Rhode Island, reconnaissance ......... TEI- 67

Sandstones

United States. ............. TEI-168

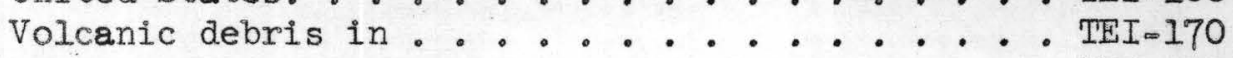

Schroeckingerite, Wyoming, Sweetwater County . . . TEI-302, TEM-10, 10A, TEM-183, 244,284

TEM-288, 518

Secondary uranium deposits, United States. . . . . TEI-168

Sedimentary rocks

Characteristics of marine uranium-bearing. . . . J-66

Cross stratification, terminology........ TEI-269

Radioactivity of ............ TEM- 59

Stratification, terminology. ........ TEI-269

Semiannual progress reports, trace elements. . . . TEI=310, 330, 331, 
Shales

Alabama................. TEI- 22, TEM-240

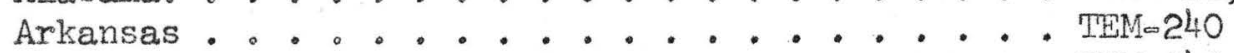

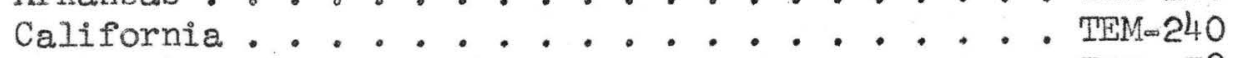

Characteristics of carbonaceous and bituminous. . TEI- 78

Chattanooga.

TEI $\infty 22,58,62$,

TEI $93,224,366$,

TEM $63,280,333$,

$T E M=553,649$, Jol 108

Origin... . . . . . . . . . TEI 237

Colorado.................. . . . TEM-240

Connecticut. ................ TEM-240

Florida. . . . . . . . . . . . . TEM-240

Green River oil shale. . . . . . . . TEM= 53, 53A

Idaho

Bonnevilie County, Fall Creek area... . . TEM-340

Cassia County, Goose Creek district. ... . TEI-272, TEM-34I

Illinois.............. TEM-240

Indiana. . . . . . . . . . . . . TEI- 1, 64, TEMc240

Iowa ..................... TEM-240

Kansas . . . . . . . . . . . TEI 18, TEM-240

Kentucky .......................... TEI 1, 22, 43, 64,

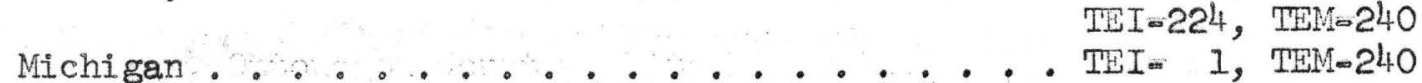

Ontonagon County, White Pine mine..... TEM=158

Mineralogy . . . . . . . . . . . TFM- 95

Mining . ............... TEM- 47

Missouri .............. . . TEM-240

Ste. Genevieve County, Bussen's Quarry . . TEM- 28

Montana. . . . . . . . . . . TEM-240, 446

Nebraska .............. . . TEM-338

Nevada............................. TEM, 338

Elko County, Goose Creek district. ... . TEI-339

New Jersey ............... TEM-240

New Mexico

Rio Arriba County. . . . . . . . . TEM=309

Sandoval County. .......... TEI-24I, TEM-278

New York . . . .......... TEI- 1, TEM-240

North Carolina ............. TEM-240

North Dakota............................ TEM-240

Oklahoma . . . . . . . . . . TEI- 18, TEM-240

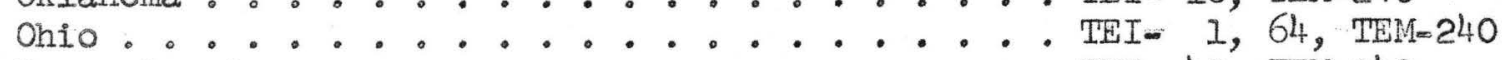

Pennsylvania............. . . TEI 43 , TEM 240

Tennessee. . . . . . . . . TEI 1, 22, 43, 58, TEI $62,63,64,93$,

TEI-224, 366, TEM-43,

$T E M=240,280,333$,

Texas.................. . . TEM-240

United States. . . . . . . . . . . TEI-168

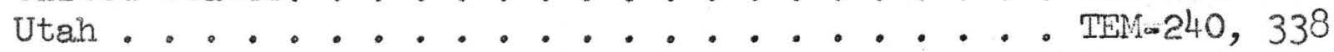

Boxelder County, Goose Creek district. . . T TEI 339 
Shales (cont'd)

Virginia. ................. TEI- 1, 64, TEM-240

Western United States ........... TEI-38I

West Virginia .................. . . 43 , TEM-240

Wyoming ................... TEM-122, 240,338

Shinarump conglomerate

Age determination ........... J-98

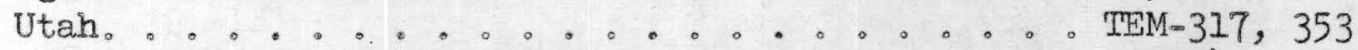

Smelter products, sampling program. ....... TEI-242 South Carolina.

Airborne radioactivity urvey ......... TEM-673

Charleston County ...... TEM-246

Heavy minerals............. TEM- 23

Monazite, placers ................ TEI-349, TEM-21, 248 ,

Phosphate, Charleston County. ........ TEM-246

Reconnaissance. ............ TEI-352

South Dakota

Airborne radioactivity survey ........ TEM-748

Autunite................. TEM-559

Beryl ................ TEI-226

Black Hills . . . . . . . . . T TEI-346, 355

Coals ............... J J 20

Custer County ................. TEI-155, 225, 231, 294

Airborne radioactivity surveys

Harney Peak quadrangle, parts ..... TEM-748

Hermosa quadrangle, parts ...... TEM-748

Fall River County ............ TEI-297

Craven Canyon area. . . . . . TEM-152, 166

Edgemont. .......... J . . 5

Geobotanical studies......... TEM-163

Harding County, lignite ......... TEI-238, TEM-342

Lawrence County ............ TEM-559

Bald Mountain mining district ....... TEM-740

Lignites................. TEI-123, 238,

TEM-126, 175,

TEM-341, 342

Pegmatites. . . . . . . . . TEI-155, 225, 226, TEI-231

Pennington County, beryl.......... TEI-226

Perkins County, lignite ......... TEI-238

Reconnaissance. ................ TEI- 4, 20, 21,

TEM-519

Stream gravels, radioactivity of. ........ TEM-629

Synthesis of uranium minerals .......... TEI-107 
Tables

Calculation of radioactive equilibrium from Bateman's equation ........... TEI-333

Simplifying calculations of activities Tantalum produced by thermal and pile neutrons..... TTE 401

\section{Tennessee}

Geochemistry ............... T TEI $31 \mathrm{~J}$

Occurrence .................. TEI 14

Asphaltite ............. TEI 43

Coals. ...................... TH 43

Eastern Highland rim......... TEI 62

Reconnaissance . . . . . . . . . TEI 8, 21, 352

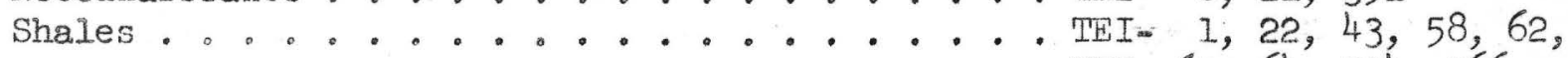
TEI- 63, 64, 224, 366, TEM $-43,240,280,133$

Texas

Amaril10 helium district, radon-bearing gas. .. . TEM-131

Chambers County, Bakers Hill oil field.... . TEM- 27

Coals.................. J-20

Glassock County, Howard-Glassock oil field . . . TEM-141

Hockley County, Yellowhouse field. . . . . . TEM-129

Howard County, Howard-Glassock oil field... . TEM-14I

Panhandle, radon in helium-bearing gas . . . . TEM-239

Panhandle gas field, radon and helium in natural

gas .....................

Radon bearing gas, Amarillo helium district. . . THM-131

Reconnaissance ................ . TEI 9

Thorium

Shale. . . . . . . . . . . . TEM-240

Alaska . . . .............. TEM-339

California ................. TEI-25I

Colorado.............. TEI-251, 353

Custer County, Wet Mountains ...... TEI-354, TEM-287

Fremont County, Wet Mountains. . . . . TEI-354, TEM-287

Florida phosphate............ TEM- 46

Idaho, Lemhi Pass district ........ TEM-560, J-84

Isotope geology. .............. TFI-209

Montana, Lemhi Pass district...... TMM-560, J-84

United States. .............. TEM- 39

Thucholite, Colorado, San Miguel County . . . . . TEM-307

Torbernite

Colorado, Clear Creek County, Robineau claims. . TEMa 24

New Jersey, Hunterdon County, Stockton . . . . TEM-125

Trace elements investigations. . . . . . . TEI 30,33

Trace elements laboratory, progress reports TEI-101, 148, 151, TEI 167 , 182, 218, TEM-174, 250

Trace elements program ........... TEMa 78, 81

Interest to petroleum geologists...... . TWM 75

Transient gas flow ............. TEI 329

Triassic formations. . . . . : . 
194

$-U=$

United States

Berylliurn resources, non-pegmatitic...... . TEI-137

Distribution of uranium deposits ....... . TEI-168

Fluorite ................ TEI-168

Iignites ................. . TEI-168

Limestones................... TII-168

Northwestern phosphate field ........ . TEM- 64

Mineralogy ............ TEM- 94

Sampling and mill studies. ....... THM 65

Pitchblende deposits............. TEI-168

Sandstone deposits ............................. 168

Secondary uranium deposits .......... TEI-168

Shales ................. TEI 168

South-central..................... TEI 350

Southwestern, copper-bearing sandstones. . . . . TEM-510

Thorium resources. ............ TEI-150, TIN-39

Trace elements program ........... TEI 35, 36, 207, 208

Uranium deposits ............. TEI-150, J-67

Western. ................. THI 199

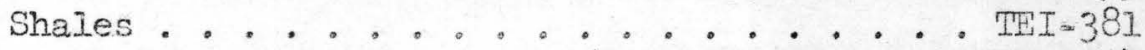

Uranium minerals, identification of, Colorado Plateau . TEI-334

Uranophane, Wyoming, Niobrara County, Lusk . . . . TEI-158, J-121

Uranothorianite

Alaska, Seward Peninoula, Candle quadrangle. . . TEM-355

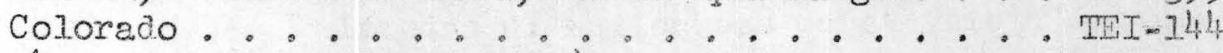

Utah (See a.jso Colorado Platesu). . . . . . . . TEI-230

Beaver County. ..................... TEI $-21,24$

Indian Creek prospect........... TEM-212

Stazts fluorspar mine.......... TWI 50

Boxelder County, Goose Creek district. ..... TTI-339, IMU-432

Burch Canyon.................. TEM-713

Carbonaceous rocks ............ TEI-281, 336, TTM-444

Carbon County. .............. TEI-21, $24, T \mathrm{TE}-444$

Castle Valley, Round Mountain stock. . .... . TEI=342

Daggett County, Yellow Canary claims ...... TTEI-124, TEM-313

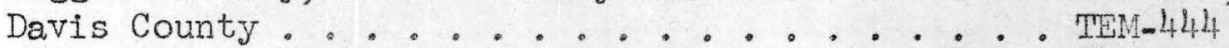

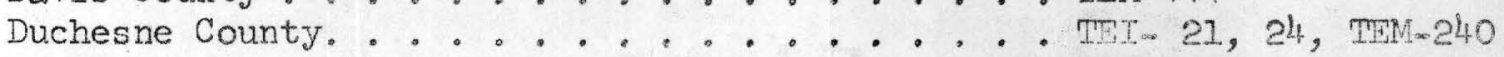

Brush Creek-Diamond Mountain area. . . . OM-f

Duchesne River area.......... OM-c

Limestone. ........................ 308

Moon Lake area.............. OM-d

Uinta River area........... OM-f 


\section{Utah $\left(\operatorname{cont}^{9} \mathrm{~d}\right)$}

Emery County

Desert Lake-9 quadrangle

TEI $=21,24,232$

Desert Lake- 11 quadrangle.

TEM-737

Desert Lake-14 quadrangle. ....... TEM-651

Emery- I quadrangle o. . . . . . . TEM-591

Emery-8 quadrangle ............ TEM-593

Emery 9 quadrangle . . . . . . . T TEM 588

Emery-16 quadrangle。. . . . . . . TEM-546

Moab-13 quadrangle ...........TEM- 731

San Rafael Swell . . . . . . . TTEM-290

Stinking Spring Creekm2 quadrangle.... TEM-589

Stinking Spring Creek-3 quadrangle .... TEM=542

Stinking Spring Creek-4 quadrangle .... TEM-532

Stinking Spring Creek 5 quadrangle.... TTM-528

Stinking Spring Creek-6 quadrangle... . TTM-530

Stinking Spring Creek-7 quadrangle .... TEM-550

Stinking Spring Creek-8 quadrangle ... . . TEM-657

Stinking Spring Creek-9 quadrangle .... TEM-650

Stinking Spring Creek-10 quadrangle.... TEM-543

Stinking Spring Creek-11 quadrangle.... TEM-383

Stinking Spring Creek-12 quadrangle. . . . TEM-384

Stinking Spring Creek-13 quadrangle. . . . TEM-397

Stinking Spring Creek-14 quadrangle.... TTM-394

Stinking Spring Creek-15 quadrangle.....TEM-545

Temple Mountain district ........ TEM-482

Shinarump mesa........... TEI- 51

Tidwe11-4 quadrangle ..........TMM-655

Tidwe11-5 quadrangle ..........TEM-642

Tidwell-9 quadrangle .......... TEM-660

Tidvell-15 quadrangle。......... TEM-656

Tidwe 11016 quadrangle. ........ TEM 617

Woodside-13 quadrangle........ TEM- 659

Fischer Valley-Sinbad Valley anticline..... J-86, OF-n

Fluorite o................ TEI-136, TEM-54

Juab County, Thomas Range. . . . . . T TEM-167, 534, J-90

Fluorspar。。.。.。. ......... TEI- 50, 252

Cammam ray logging, San Juan County, Carrizo

Mountains . . . . . . . . . . TEM-486

Garfield County

Circle Cliffs-1 quadrangle ....... TEM 586

Circle Cliffs-2 quadrangle ...... TEM-548

Circle Cliffs-3 quadrangle ....... TEM-549

Circle Cliffsm quadrangle ........TEM-634

Circle Cliffs -5 quadrangle ....... TEM-635

Circle Cliffs-6 quadrangle ....... TEM-585

Circle Cliffs-7 quadrangle . . . . . . TTM-590

Circle Cliffs-8 quadrangle ....... TEM-595

Circle Cliffs-9 quadrangle ....... TEM-529

Circle Cliffs-10 quadrangle....... . TEM-53I

Circle Cliffs-11 quadrangle. ...... TEM-636 
Utah (cont' $d$ )

Garfield County (cont'd)

Circle Cliffs-14 quadrangle. ...... TMM 637

Circle Cliffs-15 quadrangle. . . . . . TEM-641

Circle Cliffs-16 quadrangle. ...... TEM-614

Kaiparowits Peak-8 quadrangle. . . . . TEM-661

Kaiparowits Peak-9 quadrangle. . . . . . TTM-663

Mount Pennell-5 quadrangle ....... TEM-596

Mount Pennel1-11 quadrangle....... TEM-633

Mount Pennell-12 quadrangle. . . . . . TEM-597

Mount Pennel1-13 quadrangle....... TEM-615

Mount Pennell-14 quadrangle. . ..... TEM-613

Notom-15 quadrangle. ......... TEM-640

Orange Cliffs-9 quadrangle ....... TEM-732

Orange Cliffs -10 quadrangle. ...... TEM-618

Orange Cliffs-11 quadrangle....... TEM-523

Orange Cliffs-12 quadrangle. ...... TEM-524

Orange Cliffs-13 quadrangle....... TEM-500

Orange Cliffs-14 quadrangle. . . . . . TEM-501

Orange Cliffs-15 quadrangle. ...... TEM-653

Geobotanical studies

Grand County, Thompsons district, Yellow

Cat area........... TFM-273, 579

Piute County, Marysvale area ....... TEM-483

Temple Mountain district . . . . . . . TEM- 482

Geochemical studies, Wayne County, Capitol Reef

area. ................ TEM-643

Geophysical investigations, San Juan County,

Happy Jack mine.......... TEM-710

Grand County .............. TI-161

Beaver Mesa area........ TEM-727

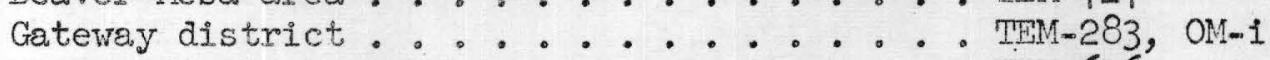

Moab-10 quadrangle ........ TEM-616

Moab-11 quadrangle ...... TEM-652

Moa.b-12 quadrangle ........ TTEM-639

Moab-13 quadrangle . . . . . . . TEM-731

Moab-14 quadrangle ......... TEM-584

Moab-15 quadrangle ......... . TEM-598

Mount Peale-1 quadrangle . . . . . . . IIM-467

Mount Peale-4 quadrangle ........ TEM-527

North La Sal Mountains, Miner's Basin. . . TEM-354

Seven Mile canyon area....... . TEI-287

Thompsons district, Yeliow Cat . . . TEM-205, 352, 579, TEM-582, 723, J-104

Geobotanical studies ........ TEM-273

Tidwell-9 quadrangle ....... TEM-660

Tidwe11-16 quadrangle. . . . . . TEM-617

Uravan district. .......... TEI-109, 283 
Utah $\left(\operatorname{cont}^{\beta} d\right)$

Ground-water studies, Morrison formation.... TMI-161, THM-137

Henry Mountains region............ OM-e

Holiday Mesa ............... TTE-712

Iron County. ............... TEI- 21, 24, TIM- 444

Juab County. ................ TTM-338

Honeycomb Hilis........... T TM-165

Jan Group. ........... TEM-162

Thomas Range, fluorite....... TEI-136, 252, TEM-167,

Kane County................ TTI- 2I, 24,

TEM-220, $534, \mathrm{~J}-90$

Bulloch group. ............ TEM-213

Circle Cliffs-14 quadrangle. . . . . . . IEM-637

Circle Cliffs-15 quadrangle. . . . . . TEM-64I

Circle Cliffs-16 quadrangle. ...... TEM-614

Mount Pennel1-13 quadrangle. . . . . . PEM-615

Mount Penne11-14 quadrangle. ....... TEM-613

Navajo Mountain-3 quadrangle .. . . . . TM-62I

Navajo Mountain-4 quadrangle ...... TEM-619

Navajo Mountain-6 quadrangle ...... TIM-620

Navajo Mountain-13 quadrangle. ..... TEM-526

Straight Cliffs-1 quadrangle . . . . . TEM-638

Straight Cliffs-2 quadrangle ..... . TEM-662

Iignite, Boxelder County, Goose Creek district . . TEI-339

Magnetic investigations............ TTEI-342

Millard County .............. TEM-240

Monzonite, Sevier County, Sevier Plateau . . . TEM 151

Morrison formation, ground-water studies... . TEM-137

Pegmatites ............... P-227

Phosphate, Phosphoria formation. . . . . TEI- 94, 142, 185,

TEI- $246,263,271$,

TEI-360, TEM-62, 194,

$\mathrm{J}-64, \mathrm{OF}-\mathrm{a},-\mathrm{m},-\mathrm{p}$

Piute County

East Slope $\|_{2}$ prospect......... TEM-21I

Marysvale. ................... T3, 169

Geobotanical studies...... . TEM-483

Papsy's Hope prospect. ....... . TEM-145

Papsy's Hope No.2........ TEN-22I

Pre-Morrison formations. . . . . . . . . . THM-249

Radon, Grand County, North La Sal Mountains. . . TEM-35

Reconnaissance ............. Tए... TI- $24, \mathrm{TEM}-290$

Rich County, Laketown. . ......... ITE 72

Salt Iake County ............. ... TEM-338

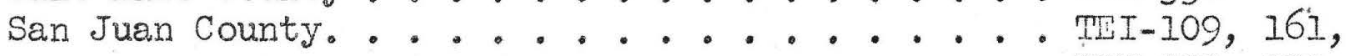

Tim-290, 353

Aneth-I quadrangle .......... TMM-452

Aneth-2 quadrangle ......... TEM-364

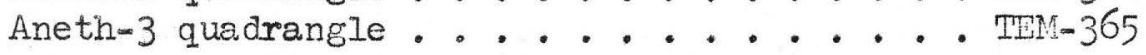


Utah $\left(\operatorname{cont}^{\circ} \mathrm{d}\right)$

San Juan County (cont?d)

Aneth-4 quadrangle ........... TEM-366

Aneth-5 quadrangle .......... TIM-393

Aneth-6 quadrangle .......... TEM-400

Aneth-7 quadrangle .......... TEM-367

Aneth-8 quadrangle ......... TEM-368

Bluff quadrangle, parts of ........ TEM-671

Bluff-1 quadrangle .......... TEM-369

Bluff-8 quadrangle .......................

Bluff-13 quadrangle. .......... TEM-371

Bluff-14 quadrangle. .......... TEM-401

Carlisle-1 quadrangle. .......... TEM-372

Carlis le-2 quadrangle.......... TEM-667

Carlisle-3 quadrangle.......... TEM-592

Carlisle-4 quadrangle. ......... TEM-547

Carlis le-5 quadrangle. ......... TEM-544

Carlisle-6 quadrangle. ......... TEM-587

Carlisle-8 quadrangle。......... TEM-373

Carlis le-9 quadrangle。......... TEM-374

Carlisle-10 quadrangle .......... TEM-669

Carlisle-15 quadrangle ......... TEM-668

Carlis le-16 quadrangle ......... TEM-375

Carrizo Mountains, gamma-ray logging . . . TWM-486

Clay Hills-12 quadrangle .........TEM-413

Clay Hills-13 quadrangle ......... TEM-409

Clay Hills-14 quadrangle ......... TEM-442

Clay Hil1s-15 quadrangle ........TTM-414

Clay Hills 16 quadrangle ........ TEM-449

Comb Ridge area, parts of Bluff quadrangle. TEM-671

Elk Ridge。 . . ........... TEM-714

Elk Ridge-1 quadrangle ......... TEM-410

Elk Ridge-8 quadrangle .......... TEM-407

Elk Ridge-9 quadrangle ......... TEM-453

Elk Ridge-12 quadrangle......... TEM-396

Elk Ridge-13 quadrangle......... TEM-376

EIk Ridge-16 quadrangle. ........ TEM-377

Camma-ray logging, northwest Carrizo

Mountains . . . . . . . . TEM-486

Happy Jack mine............ TEM-645

Geophysical investigations ....... TEM-710

Monument Valley。 ........... TEI-321, TEM-535

Holiday Mesa ............ TEM-712

Mount Peale-I quadrangle ........ TEM-467

Mount Peale-4 quadrangle ........ TEM-527

Mount Peale-5 quadrangle ........ TEM-378

Mount Peale-6 quadrangle . . . . . TEM-379, 379 A

Mount Peale-7 quadrangle ........ TEM-466

Mount Peale-8 quadrangle ....... TEM-465

Mount Peale-9 quadrangle ........ TEM-450 


\section{Utah (cont'd) \\ San Juan County (cont'd.)}

Mount Peale-10 quadrangle........ TEM-45I

Mount Peale-1l quadrangle. . . . . . . TEM-380, 380A

Mount Peale-12 quadrangle. ....... TEM-381

Mount Peale-15 quadrangle. ....... TIM-447

Mount Peale-16 quadrangle. . . . . . . TEM-448

Navajo Mountain-3 quadrangle ....... TTM-621

Navajo Mountain-6 quadrangle . . . . . TEM-620

Navajo Mountain-9 quadrangle . . . . . TEM-469

Navajo Mountain-13 quadrangle. . . . . . TEM-526

Navajo Mountain-16 quadrangle. ...... TEMa470

Orange Cliffs-l quadrangle ........ TTM-665

Orange Cliffs-8 quadrangle ....... TEM-654

Orange Cliffs-15 quadrangle. ...... TIM-653

Paradox district, Gray Daun area . . . . . TMM-480

La Sal Creek area. . . . . . . . TEM-724

Vanadium queen group . . . . . . TEM-715

Red House Cliffs area. . . . . . . TEM-537

Verdure-1 quadrangle . . . . . . . TEM-399

Verdure-2 quadrangle . . . . . . . . TEM-406

Verdure-3 quadrangle ......... TEM-433

Verdure-4 quadrangle . . . . . . . . TEM-438

Verdure -5 quadrangle .......... TEM-408

Verdure-6 quadrangle ......... TTML-405

Verdure -7 quadrangle ........ . . TEM-395

Verdure-8 quadrangle ......... . TEM-403

verdure-9 quadrangle ......... TLM-385

Verdure-10 quadrangle. . . . . . . TTM-385

Verdure-1l quadrangle. . . . . . . . TEM-387

Verdure-12 quadrangle. . . . . . . TEM-388

Verdure-13 quadrangle. . . . . . . . TTM-389

Verdure-14 quedrangle. . . . . . . . TEM-390

Verdure-15 quadrangle. . . . .... TTM-391

Verdure-16 quadrangle. . . . . . . TEM-392

Thite Cenyon ............ TEI-205, 320, TEM-7, TTEM- 7A, 325, 54:0

Deer Flat, geophysical investigations. . TEM-627 Gonway and North Point claims. . . . . TTI-240 Tiger (Hideout) claim. . . . . . TMN-479

Sanpete County .............. TEM-44! Sevier County

Black Hill ........... . TEM-150

Sevier Plateau, Dry Creek canyon ...... . TEM-I5I

Tiger Eye No. 1 prospect . . . . . . TLM-164

Shale.................... TT-339, TMM-240, 338

Shinarump conglomerate . . . . . . . TIM-317, 353

Tooele County, Sheeprock Mountains ...... THM- 36

Triassic formations.......... TEI-313 
Utah (cont'd)

Uintah County. ............ TEI- 21, 24, 232, TEM- 240

Brush Creek-Diamond Mountain area. ..... ON-f

Carbonaceous rocks, Vernal area. ..... TEI-336

Coal ............... TEI-281.

Eureka and Happy Landing groups. . . . . TEM 32

Uinta Basin. . . . . ...... TEI-308

Uinta River area . . . . ...... ON-f

Uranium-vanadium ore, potential production ... TTEI- 89

Vanadium deposits................. B36, OH-b

Utah County................. TEI $24, T E M-338$

Wasatch County ............. TEI- 24

Duchesne River area............ OM-C

Washington County. .......... TTI- 21, 24, J-105

Silver Reef district......... MEI-254, TEM-214

Wayne County ............ TEI-232

Capitol Reef area........... TII-203, 319,

Carlisle-4 quadrangle.......... TEM-547

Carlisle-5 quadrangle. ......... TFM -544

Miners Mountain area .......... OF

Mount Peale-13 quadrangle. . . . . . . TEM-398

Mount Peale-14 quadrangle. . . . . . . TEM-382

Mount Penneli-14 quadrangle. ...... MEM-613

Orange Cliffs-1 quadrangle ........ TMM-665

Orange Cliffs-2 quadrangle ....... TMM 600

Orange Cliffs-3 quadrangle . . . . . . TIM $=594$

Orange Cliffs -4 quadrangle ....... TEM-664

Orange Cliffs 5 quadrangle ....... TEM-525

Orange Cliffs-6 quadrangle....... TEM-599

Orange Cliffs -7 quadrangle ....... TEM-612

Orange Cliffs-8 quadrangle ........ TEM-654

Orange Cliffs-9 quadrangle ........ TEM-732

Orange Cliffs-10 quadrangle. ....... TEM-618

Orange Cliffs-11 quadrangle. ....... TTM-523

Orange Cliffs-12 quadrangle. ....... TEM- 524

Weber County ............... TEM-338 
201.

$-V=$

Vanadum minerais, identification of, Colorado Plateau. THI- 334

Venezuela.................... TEI-222, TEMm 331

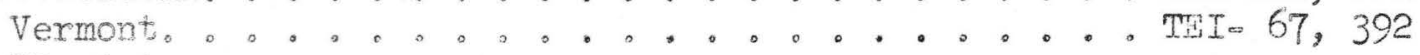

Virginia

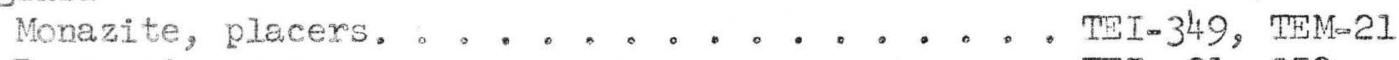

Reconnaissance................ TEI- 21, 352

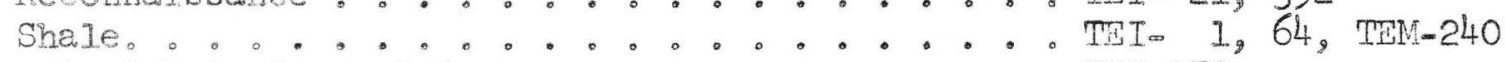

Volcanic debris in sandstones............ TTI×170

$-N=$

Wagon drilling

Sample collectors for cuttings........ TPI-213

Sampling .................... . TII-217

Weshington

Carbonaceous rocks ............ ThM 444

Granitic rocks........................ . . . 343

Iincoln County ................ THM-197

Reconnaissance . . . . . . . T I Vater

Analyses, California, Salton Sea...... TrM- 42

Fresh, radioactivity ........... TWM- 59

Natural, uraniun in............. TEM475

Non-saline 。............... TM-281

Ser, radioactivity ............ TEM- 49, 59

Trace elements concentrations....... J.57

Uranium determinations ......... TEM-305

Wavellite, Florida...............TEM-507

West Virginia

Asphaltites....................... TEI 43

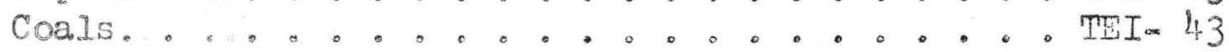

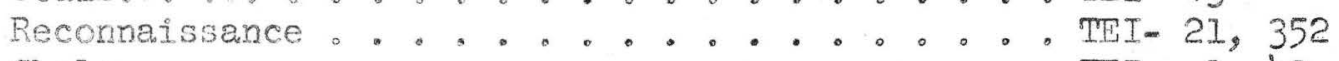

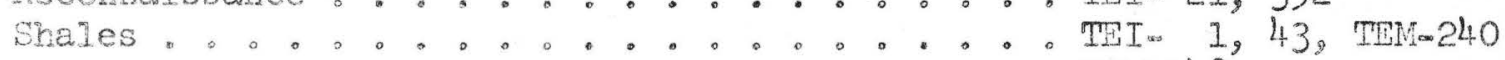

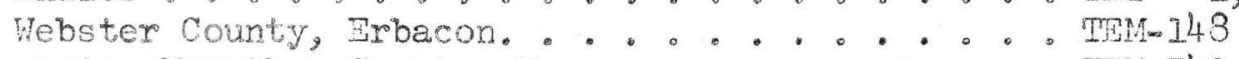

Wisconsin, Marathon County, Wausau ...... TEM-742

Wyoming

Airborne radiosctivity survey

Campbell County。...........TEM-509

Carbon County, Bagss quadrangle, parts... TEM-743

Miller Hill area.......... TMM-606

Sand Creek quadrangle, parts ..... TMM-744

Saratoga quadrangle. . ....... THM 746

Severy quedrangle, parts of. . . . TMM 745,747

Crook County, Devil's Toner area..... TEM-605 
202

Wyoming (cont'd)

Airborne radioactivity survey (cont'd)

Fremont County, Tabernacle Buttes..... TEM-510

Johnson County, Pumpkin Buttes ....... TEM-508

Sublette County, Tabernacle Buttes . . . . TEM-610

Sweetwater County

Aspen Mountain area......... TEM-609

Baggs quadrangle, parts. ...... TEM-743

Red Desert........... TEM-147

Uinta County, West Lonetree area...... TEM-611 Campeli County

Pumpkin Buttes area. . . . . . . . . TEI-345, TEM-572

Airborne radioactivity survey. . . . . TEM-508

Carbonaceous rocks ............. TET-28I, 336

Carbon County

Ba.ggs quadrangie, airborne radioactivity

survey. ............. TEM-743

Miller Hill area.......... TEI-315

Airborne radioactivity survey. . . . . . TEM-606

Sand Creek quadrangle, parts . . . . . . TEM-744

Saratoga quadrangle, airborne radioactivity

survey. ............ TEM-745

Savery quadrangle, airborne radioactivity Coal

survey. ................ TEM-745, 747

Converse County. . . . . . . . . . TEM-195

Sweetwater County, Red Desert. . . . . TEI-332, 389, TEM-601

Converse County, Mountain Home cos.l mine . .... TEM-195

Crook County, Bear Lodge Mountains ...... TEI-172

Devil's Tower area, airborne radioactivity

survey. ............ T世M-605

Fremont County

Gas Hills area . . . . . . . TEM-708

Tabernacle Buttes area, airborne

radioactivity survey。......... TEM 610

Geobotanical studies, Sweetwater County. . . . . TEM-484

Goshen County, Rawhide Buttes area ...... TEM-293

Green River basin........... J-58

Hartville area, Paleozoic rocks........ OM-g

Johnson County

Pumpkin Buttes ........... TEI-345, TTM-572

Airborne radioactivity survey. . . . . TEM-508

Lignites . . . . . . . . . . TEI-123, TEM-126

Lincoln County, coal ........... TEI-281, 308

Natrona County, Cas Hills area...... TEM-708

Niobrara County, Lusk, Silver Cliff mine . . . TEImI58, J-121

Rawhide Buttes area. . . . . . . . TEM-293

Pegmatites .............. P-227

Phos phate, Phosphoria formation. . . . . . TEI- 94, 142, 184, TEI-246, 263, 27I, TEI $-363,377,378$, TEM- 62, $194, \mathrm{~J}-64$, OF $-a,-b,-g,-m,-p$ 


\section{3}

Wyoming (cont'd)

Powder River Basin, Pumpkin Buttes ...... TEM-341, 573, 676, TEM-677, C-176

Reconnaissance ................ TEI 4, 20, 21, 72, TEI-232, TEM-290

Schroeckingerite, Sweetwater County. ..... TrI-302, 308, TIM-10, TEM $10 \mathrm{~A}, 183,244$, TTM-284, 288, 518

Shales ... . . . . . . . . TEM-122, 240, 338

Split Rock area. . . . . . . . . TEM-282

Sublette County, Tabernacle Buttes, airborne radioactivity survey。.......... TEM-610

Sweetwater County, Aspen Mountain area.

Airborne radioactivity survey. ..... TEM-609

Baggs quadrangle, airborne radioactivity survey. ................ TEM-743

Geobotanical studies ........ TMM- 484

Lost Creek, schroeckingerite ....... TEI-302, TEM-10, 10A, $T \mathrm{TE}-183,244,284$, TEM-288, 518

Red Desert area。.......... TEI-122, 332, 372, TEI-389, TTEM-96, TEMM- 341,601

Airborne radioactivity survey. .... TEM-147

Uinta County, West Lonetree area, airborne radioactivity survey。 ..........TEM-611

Uranophane, Niobrara County. ....... TEI-158

Wind River basin ............ TEM 445

$-\mathrm{X}-\mathrm{Z}-$

Yenon, occurrence. . . . . . . . . . . . TEI I 11

Zeunerite, Alaska。............. TEIm57D, 221

Zirconium。........................... 66

Zonal relations of uranium deposits......... TEM-521 



\section{4}

PART TV. FINDTNG LIST OF AUTHORS

If a TE number is given, the reader should look in Part I under the given TEI or TEM number. If any other reference is given, i.e., OF, $B, C$, etc., look in the appropriate section of Part II.

$-A=$

Aberdeen, E. J。 (and White, Sherwood, Bruce, Ferguson). TEM-281

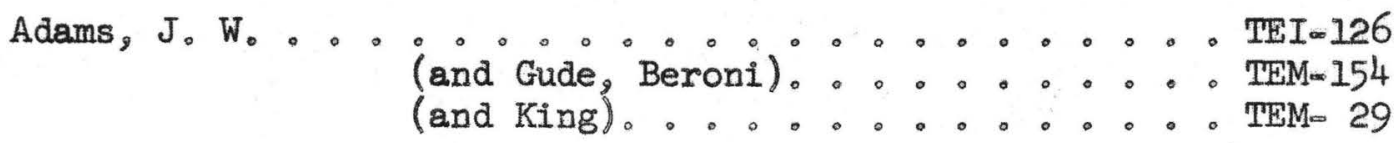

Albee, H。 F。 (with Sample) . . . . . . TEM-206, 207, 208, $-266,267,268$, $-345,346,347$, $-348,349,456$, $-457,462$

(with Sample, Stephens) ......TEM-350, 351, 458, (with Williams, Cadigan, Stewart) 。. TEI-313

Altschuler, Z. S.. 。. . . . . . . . . . . TEI-266 TEM- 89, 98, 238, $-478$

(and Berman, Owens, Delevaux, Lundine)。TEM 604 (and Boudreau). . . . . . . TEI- I02 (and Cisney). 0.0 .0 .0 .0$. (and Jaffe, Dwornik)。....... TEM-237 (with McKelvey, Cathcart, Swanson, R.Wo, Lutz) . . . . . . . . . . TEI-27I (with Owens, Berman).。......TEI-316

Alvord, $D, C$. . . . . . . . . . . . . . TEI-289 $T E M=352,628,496$, $-497$

Anderson, F.J. . . . . . . . . . . . . . TEI 72 $\ldots \ldots$................ 26 
Anderson, J. W. (with Fletcher, May)........ TEI 133

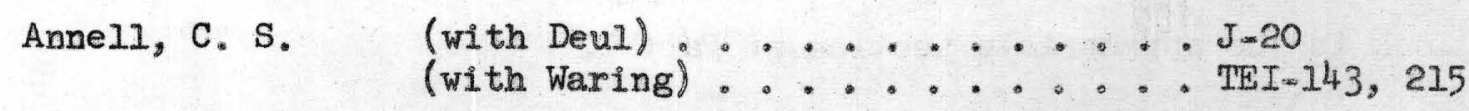

Armstrong, F. C.................. TEI-177, J-3

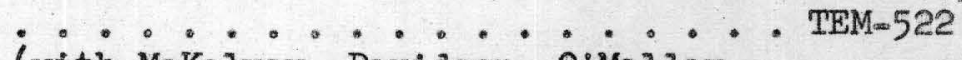

(with McKelvey, Davidson, O'Malley,

Smith, I. E., Sheldon)....... TEI-183

(with McKelvey, Gulbrandsen,

Campbe11). .......... TEI-187

(with McKelvey, Smith, L. E.,

Hoppin)............ TEI-184

Axelrod, J.M. (and Grimaldi, Milton, Murata). . . J-4

$$
-\mathrm{B}=
$$

Bachman, G. O. (and Baltz, O'Sullivan) ...... TEI-198

(and Read)........................... 309, 435, 443

(with Denson, Zeliex) . ..... TEM-175

(with Read, Sample) o. ...... TEM-510

(with Vine, Read, Moore, G. W.) .. TEI-241

Baker, R. C. (with Klemic) ......... TEM-503

Bales, W. E.

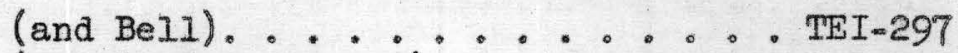

(and Bell, Wilmarth)........ J.. 5

(and Erickson)......... TEM-166

Balsley, J.R, (with Stead, Moxham, Reinhardt) . .TEM-508 
Baltz, E。H, Jro (with Bachman, O'Sullivan)。。。. TEI-198

(with Zeller)。.。. . . . TEI-338

(with Zeller), . . . . . . TEM-556

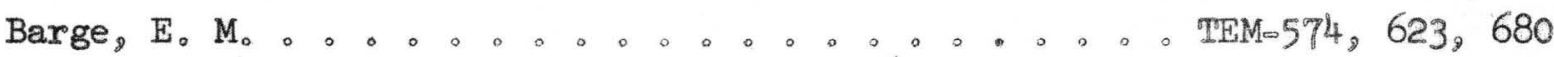

Barnett, P.R。 (with Myers) 。。。。。。。。。.TEI- 179

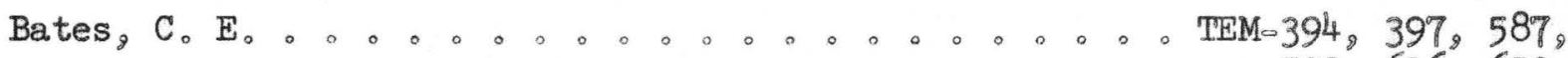

(and Eckstein). 。. 0.0000 TEM 4449

$-592,616,652$

(and Hos ley). 0.0 .0 .0 TEM 660

Bates, $R_{0} G_{0} \circ \circ \circ \circ \circ \circ \circ \circ \ldots$

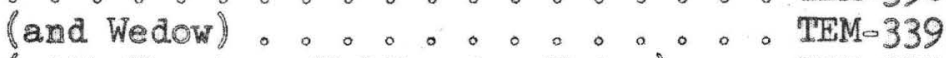

(with Houston, Velikanje, Wedow)。. TEI-293

(with Wedow, Grantz, Houston,

Killeen, Natrko, Nelson, Stejer,

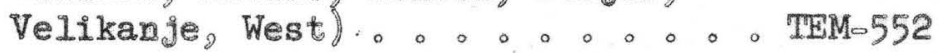

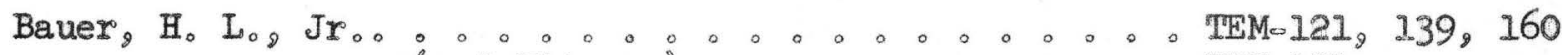

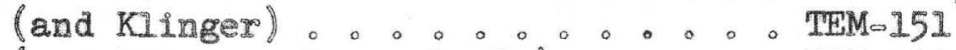

(and Klinger, Page, Io Ro)。。。。-TEM-150

(and Staatz).。. 0.0 .0 .0 TEM-220

(with Beroni) 。. 。. 。. 。. TEI-123

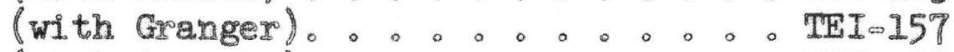

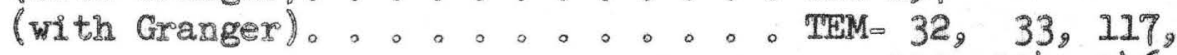

(with Granger, Lovering, $T_{0} G_{0}$, $-119,134,146$

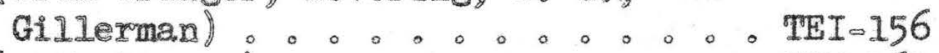

(with Staatz) $0.0 .0 .00 .0 . T E M=165,167,226$,

(with Startz, WiImarth) 。. . . TEI 136 $-227,228, J=90$

Baumgardner, L. H。 (with Moxham, WaLker) 。。。。。-TEIm380 
Becraft, G. E. ................ TEI-257, 282, J-6 ................... TEM-603

(and Rosenblum)

Bell, Henry, III............... TEI-114, 164, 286

TEM-113, 190, 191,

$-200,275,294$

(and Cramer).......... TEM=192, 257, 259

(and Iclie).......... TEM 112

(with Bales).......... TTI-297

(with Bales, Wilmarth)。..... J-5

(with Cater) ......... TEM-700

(with Cater, Bush). ....... TEM-695

(with Cater, Bush, Withington). . . TEM-699

Bell, Ko G. ............. TEI. 87

…............. TEM-311, 486

(and Rogers)........... TEI. 84

Benson, P。 D. (with West) ......... TEI 73,189

Benson, W. E. (and others).......... TEI-205

(and Trites, Beroni, Feeger). ... TEM-325

(with Trites, Beroni) ...... TEI-240

Bergendahl, M。 H。................. TEM-507

Berman, Josenh . . . ............ J- 8, 9 (with Laxsen, Waring, C. L.). : J 61

Berman, Robert ............. TEI-273, 314

..................... 475

(with Altschuler, Owens, Delevaux,

Lundine) ......... TEM-604

(with Owens, Altschuler). ..... TEI-316 
Beroni, $E_{0}$. 。

(and Bauer). ........ TEI-123

(and Granger, King)....... TEM- 25

(and King) . 。 . . . . . TEM-133

(and McKeown)........ . TEI-308

(and McKeown, Stugard, Gott) .... TEM-213

(and Whitebread) ...... TEM=293

(with Adams, Gude) ...... TEM-154

(with Benson, W。 E., Trites,

Feeger) ......... . . TEM-325

(with Granger) ....... TEM- 7, 20

(with Trites, Benson, $\mathrm{W}_{0} \mathrm{E}_{0}$ ) ....TEI-240

(with Wilmarth, Vickers, McKeown)..TEI=124

(with Wyant) ......... TEI- 61

(with Wyant) ........ TEM-126

Bivens, No Wo (with Dutro) ........... TEM 681,682

Black, $R_{0} A_{0} \ldots \ldots \ldots \ldots \ldots \ldots \ldots$

............. TEM-578

Black, R。B. (with Gault, Lyons)....... TIEI- 25

Blackman, D. H. . (See also Weir, D..B.)..... . TEI-119

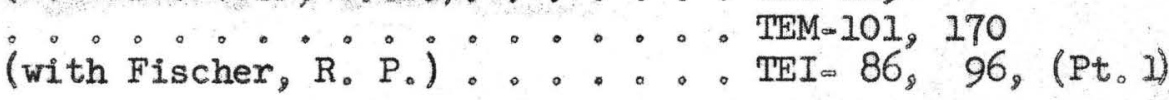

Blade, L。V。 (with Cathcart, Davidson, Ketner) 。TEI=-265

(with Cathcart, Gray) ..... TEM-477

Blatcher, $V_{0} K_{0} \quad$ (and Wallace) ....... TEI-325

(with Wallace). ...... TEI-300

(with Wallace, Smith, H。Bo) ... TEI 400

Block, Stanley (with Evans). ....... TEI-368, J-25 
Bortner, T.E, (with Meuschke, Moxham) . . . . TEM-673, 678

Bostwick, D。A. (with Swanson, R。W。, Klepper, Lowell, Honkala, Cressman, Payne, Ruppel) . . . ...... TEI-186

Botinelly, Theodore ............. TEM-94, 95, 474

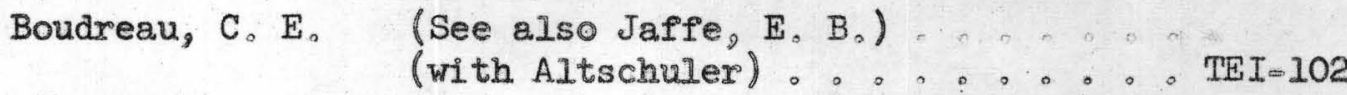

Bowers, Howard . . . . . . . . . . TEM-686

Bracken, J。 To (and Senftle) ........ TTI 402

Brasher, G。 Ko ................ TEI-163

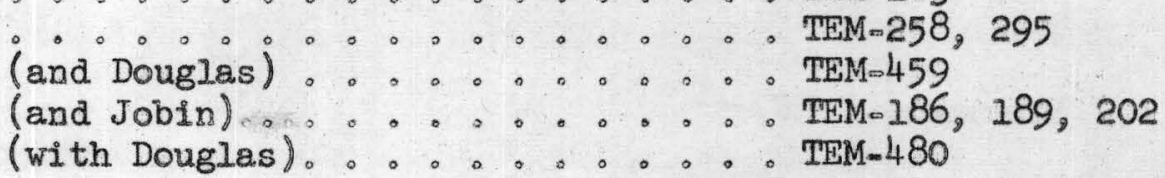

Breger, I. A. (and Deul), ......... TEI-284

(and Deul, Meyrowitz, Rubinstein) . TEI=389

(and Meyrowitz, DeuI) ..... TEI-388

(and Meyrowitz, Warr) ...... TEI $\times 372$

Brew, D, A . ............. TEI 290

TEM-274, 490, 498

Brill, K, G., Jr, (and Carroll) ..........TEI- 32

(and Nelson, J.M., Prouty) .... TEI= 8

(and Wolfe) . . . . . . . TEI- 19

(with Nelson, J. Mo). ....... TEI $=22,43$ 
Brobst, D。A................... . . . . . . . . 148

Brock, M. R. (with Singewald, Christman) . . . TEM-2I8

Brown, Andrew. .................. TEI- 93

(......................... 63, 333

(with Conant, Hass)......... TEI- 62

(with Robeck)........ TII- 63

Brown, C.No (with Fischer, R. P., MecKallor)。. TEM-205

Bruce, F。 I. (with Aberdeen, White, Sherwood,

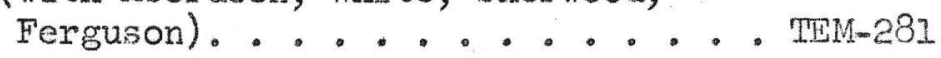

Bryner, Leonid ................. TEI-147

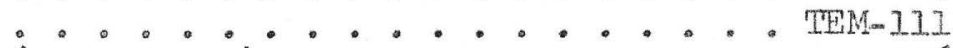

(and Cramer) . . . THM-256, 260, 261

(and Douglas) . . . . . . . TEM-296

(and Withington)....... TMM-204

(with Bush) ........ TEM-298

(with Cater)......... TEM-694

Burbank, W. S.

(and Pierson) ......... TEM-310

(with Plerson, Singewald) . . . J-81

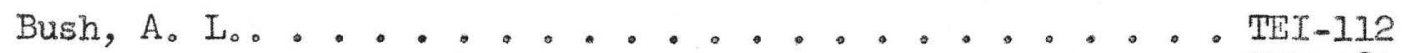

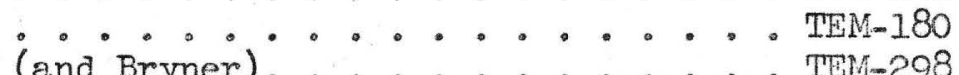

(and Hilpert, Trace). $\cdot \cdot \cdot \cdot \cdot$ THEI-116

(and Stager)............ TEI-288

(with Butler, A. P.)....... IEM-24l

(with Cater, Be11)...... TEM-695

(with Cater, Bel1, Withington). . TEM-699

(with Withington) ........ TEI-115 
Butler, A. P., Jr. . . . . . . . . TEI-207

. . . . TEM- 39, 41, 42, 76

(and Bush)........... TEM-241

(and Chesterman).........TEI- 5, 12

(and Killeen, Page, G. B., Rubey) . . TEI- 35

(and Stead)............. TEI 36

(with Fischer, R. P.) ...... TEM- 38

(with Hall, M. I.)........ TEI-242

(with McKelvey, Page, L. R。, Fischer,

R. $P_{0}$ ) ................ TEI-150, J-67

(with Narten, Crawford) ..... TEM-240

(with Rabbitt, Rubey, Lovering,

T. S., McKelvey). ....... TEI-206

(with Stokes, Russell, Fischer, R.P.) OM-I

Butler, C. R。 (with Moore, F。 B)........ TEM-198

Cadigan, R。A .................. TEM-716

(with Craig, Holmes, Freeman,

Mullens, Weir) ........ TEI-180

(with Williams, Albee, Stewart) ...TTI-313

Caldwell, D. W. (with Overstreet, Theobald, White, Cuppels, Whitlow)....... TEI-349

Cameron, E。N. (with Fleischer)........ TEI- 29, 31K (with Warner, L. A., Holser,

Wilmarth). .......... TEI-137, J-50

Campbell, R. H. (and Schafer) ......... TEM-512 
212

Campbel1, R. M. (with McKelvey, Armstrong, Gulbrandsen) ......... TEI-187

Cannon, H. L..................... TEI 160

..................... TEM-163, 199, 272 ,

(and Durre11) ........ TEM=484

$-273,575,579$

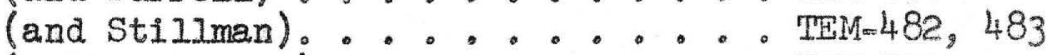

(with Starrett) ......... TEM-711

Cannon, R. S.................... TTE $-209, J=12$

............... TEM-225

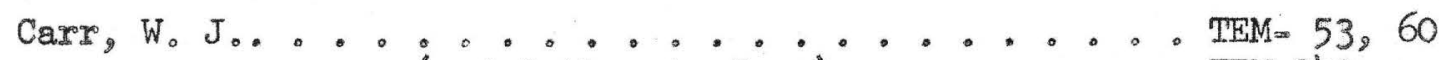

(and Cathcart, Gray)...... TEM-243

(with Cathcart, Petersen, Gray).. TIEM-436

Carroll, G. V. (with Brill).......... TEI 32

Carswe11, I. D。 (with Cheney, Sheldon, Cressman,

Smart) ............. OF $\approx b$

(with Sheldon, Cressman, Smart): . TEI-378

Carter, $W_{0} D_{0} \ldots \ldots \ldots \ldots \ldots$.......................... 715,724

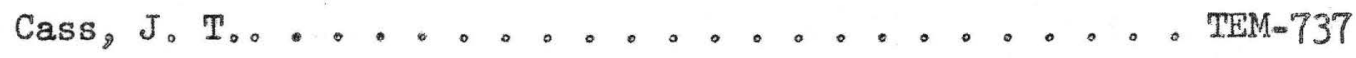


Cater, F. Wo, Jr.................... TEM $692,696,697$,

(and Bell).......... TEM-700 $-698,704$

(and Bryner).......... TEM-694

(and Bush, Bell). ....... TEM-695

(and Bush, Bell, Withington). . . . TEM-699

(and Craig, Phoenix). ....... TEI-110

(and Stager). . . . . . . TEM-693

(and Vogel) ......... TEM-702

(and Withington)......... TEM-690

(with Fischer, R。 Po, Hilpert,

Schumacher, Strobell, Craig,

Phoenix, Trace). ...... TEM-276

Cathcart, J. B. . . . . . . . . . . . TEI $=79,85,95$, $-395, \mathrm{~J}=13$

TEM- 85, 116, 130, $-157,172,253$, $-277,334,363$,

(and Blade, Davidson, Ketner) ... TEI-265

(and Blade, Gray)....... TEM-4T7

(and Carr, Petersen, Gray).... TEM-436

(and Davidson).......... TEI-212, J-14

(and Davidson, Dutro, Ketner,

Petersen, Tiliman, Pratt). .... TEM-138

(and Houser, F。No) ...... J-15

(and McGinley). ........ TEM-464, 505

(and Tiliman, Dutro)........ TEI-141

(and Ward, E。 L。 Mo) ....... TEM 672

(with Carr, Gray) ........ TEM-243

(with Davidson, Ketner) ...... TEM-234

(with McKelvey) 。...... TEI- 94

(with McKelvey, Altschuler, Swanson,

R。 Wo, Lutz) ......... TEI-27I

(with McKelvey, Worthing) ....TEM-236

Cavender, W。 S。 (with Moore)........... TEI-228, J-72 (with Sharp).......... TEI-35I, J-84 (with Sharp). ........ TEM-286, 560

Chace, F. M. ............... TEM-136

(with Thurston, $R_{0} H_{0}$ ) . . . . TEI- 8IA 


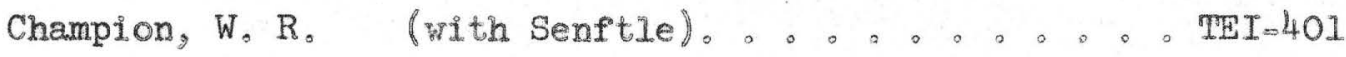

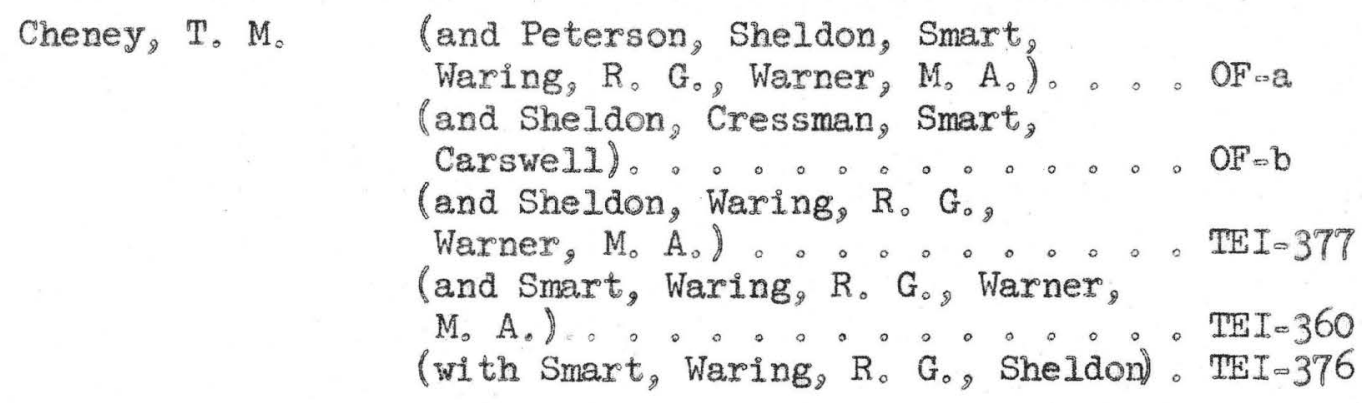

Chesterman, C.W (and Main).。. . . 。 . . TEI $=24,30$

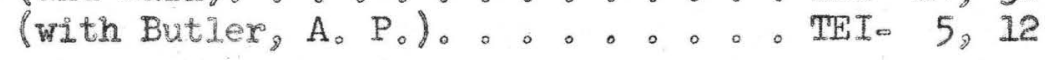

Chew, R。 To. . . . . . . . . . . . . . TEM-629 (with Trites) ......... TEM-645

Choquette, P.W. (with McKeown, KIemic)。。。 . 。 IEI-382

Christ, C.I. (and Clark, Evans)。。.。.。.。 J-16

Christman, R. A. (and Heyman, Dellwig, Gott). 。. TEI-250 (with Singewald, Brock) 。. . 。 TEM॰218 (and others)。........TEI=354

Cisney, $E$. A。

(with Altschuler) 。 $0.00 \ldots . J=2$

(with Iarsen, Fletcher) 。. . . . J-59

(with Murata, Stieff, Zworykin) 。. TEI-107

(with Weeks, Sherwood). 。. . . TEI $335, \mathrm{~J}-117$

Clabaugh, S. E。 (with Gulbrandsen, McLaughlin, Honkala, Krauskopf) 。 。 。 。 TEI-260

(with Slaughter). 。. . 。 . . . TEI- 1, 3, 9 
Clark, J.R。 (with Christ, Evans)....... Jol6

Claus, R.J. (with Witkind, Thaden, Johnson,

$\mathrm{D}_{0} \mathrm{H}_{0}$, Lough) . ....... TEI=204

(with Witkind, McKay, Johnson, D. $\mathrm{H}_{0}$

FinnelI, Johnson, D。 L。) .....TEM-318

Coats, Ro R. ................ TEM -343

Colliex, J. T. (with Sheridan, Maxwell)...... TEI-302

(with Sheridan, Sears) . .... TEM-288

Conant, I. C............... TEI $=58,237$

............. TEM-155, 280

(and Brown, A., Hass) ...... TEI- 62

(and Rowe). . . . . . . TEM-649

(and Swanson, V. E。) ....... TEI-224

(with Robeck) ......... TTI- 64

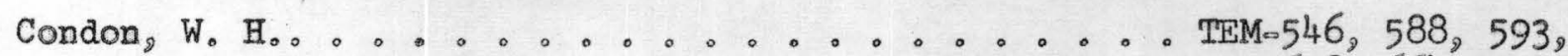

$-618,664,732$

(with Fischer, W. A.) . . . . TEM-469, 470, 499

(with Kent) ......... TEM-653

Cook, Ko I。

(and Moss).......... TEI-244

Craig, I。C.

(and Freeman) .......... TEM-209

(and Holmes). . . . . . J-18

(and Holmes, Cadigan, Freeman,

Mullens, Weir) ......... TEI-180

(with Cater, Phoenix) ...... TEI-110

(with Fischer, R, P., Hilpert,

Schumacher, Cater, Strobell,

Phoenix, Trace). . . . . TEM-276 


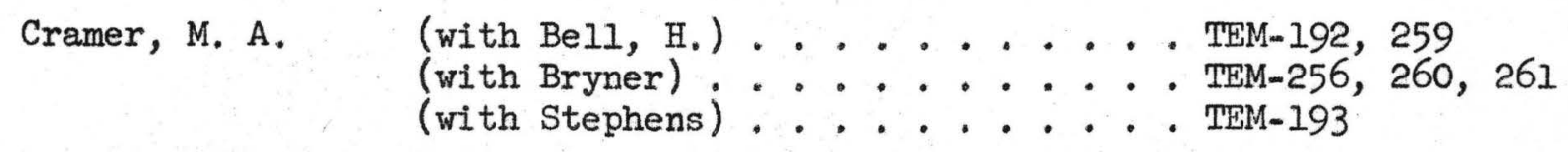

Crawford, J. E. (with Narten, Butler, A. P.). . . TEM-240

Cressman, E.R. . . . . . . . . TEI-258, J-19

(and Wilson, W. H., Tandy, Garmoe). . TEI-361

(with Cheney, Sheldon, Smart,

Carswell). . . . . . . OF-b

(with Sheldon, Carswell, Smart) . TEI-378

(with Sheldon, Smart, Waring, R. G.,

Thompson, M. E., Weiser, Jones, R.J.,

Peirce)...... OF-m

(with Swanson, Jones, Replogle) . TEI-362

(with Swanson, R. W., Klepper,

Lowell, Honkala, Bostwick, Payne,

Ruppel). ......... TEI-186

Cuppels, N. P. (with Overstreet, Theobald, White

Caldwell, Whitlow) $\therefore . . .$. TEI-349

Curtis, Diane (and Houser, S. S.)....... TEI-30I

Cuttitta, Frank. ............ TEI-152, 210,

(and Kinser)......... TEI-326

(with Frondel). . . . TEI-309, 367 
Davidson, D. F.................... TEM-246, 279, 337, $-362,573,676$,

(and Cathcart, Ketner)...... TTM-234

(and Smart, Peirce, Weiser) . . TEI-365

(and Wayland) ......... TEM-123

(with Cathcart) ....... TEI-212, J-14

(with Cathcart, Blade, Ketner). . . TEI-265

(with Catheart, Dutro, Ketner,

Petersen, Tiliman, Pratt)..... TEM-138

(with McKelvey, O'Malley, Smith, I.E.,

Axmstrong, Sheldon)....... TEI-183

(with O'Malley, Hoppin, Sheldon)...TEI-188

Davis, F.J. (with Stead) . . . . ..... J-95

Davis, $W_{0} E_{0} \ldots \ldots \ldots$ TEM-232 (and Swartz, Shujer) ...... TEI- 66

(with Fischer, R。P.) ..... TEM-196

Delevaux, M。 H。 (with Altschuler, Berman, Owens,

Lundine) ........... TEM-604

Dellwig, Io F。 . . ............ TEM-287

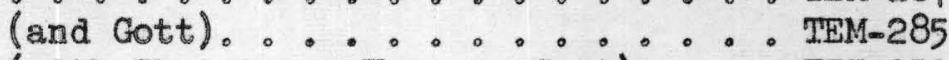
(with Christman, Heyman, Gott). . . TEI-250

Denson, N. M. ................ TEM-195

(and Bachman, Zeller) ..... TEM-175

(and others)......... TEM-34I

(with Love, Henbest)........ OM 
Deul, Maurice. . . . . . . . . . . TEM-124

(and Annel工). . . . . . J-20

(with Breger) . . . . . . . TEI-284

(with Breger, Meyrowitz). . . . . TEI-388

(with Breger, Meyrowitz, Rubinstein) . TEI-389

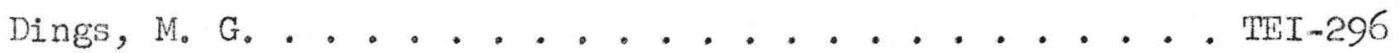

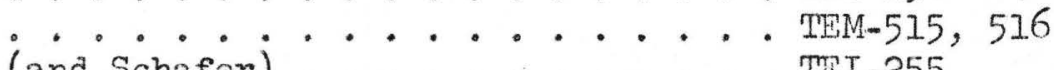

(and Schafer) ....... TTI-255

Donnay, Gabrielle............ J-21

(and Donnay, J. D. H.) : : : J-22, 23

Donnay, J. D. H. (with Donnay, G.) . . . . . J-22, 23

Douglas, R. F. . . . . . . . . . . . TEM-495

(and Brasher) . . . . . . TEM-480

(with Brasher). . . . . . . TEM-459

(with Bryner) . . . . . TEM-296

Dow, V.T. (vith Gordon, Withington) . . . . TEI-213

(with Gordon, Withington) .... TEM-298

Drake, A. A. (with Sims, Moench) ..... TEI-304

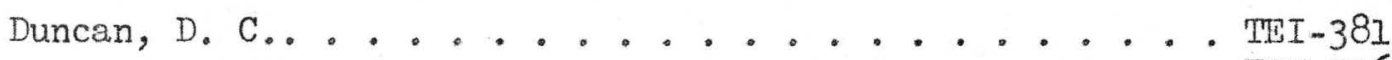

................ TEM-336, 338, 444

Durrel1, M. E. (with Cannon, H. L.)..... TEM-484

Dutro, H. B. ..................... TEM-504, 630 (and Bivens). . . . . TEM-681, 682 (with Cathcart, Davidson, Ketner, Petersen, Tiliman, Pratt). .... TIM-138 (with Cathcart, TiIIman). . . . . TTI-I4I 
Dwornik, Edward (and Ross)................. TEM 41 (with Altschuler, Jaffe)..... TEM-237

Eekstein, W. H....................... TEM 411, 414, 54.1, (with Bates, C. E。) ...... TEM -731

Eicher, I. I..................... TEM-487, 488 (and Myers, $\left.A_{0} R_{0}\right)$

Ekren, E. B。 (with stephens) ........ TEM-297

Elston, D。 P. (with Vogel)......... TEM-725

Emerick, W。 L. ............... TEM-485 (and Gualtieri) $\therefore \ldots$ TEM $625,683,684$, (with Gualtieri)........ TEM-687

Erickson, E.S., Jr.(with Stieff) ......... TEI=307

Exickson, R。 I. (and Gott)............ TEM-290

(and Myers, Horr) ........ TEM-513

(with Bales).......... TEM-166

(with Gott).......... TEI-232

Evans, $H_{0} T_{0}, J r_{0}$ (and Block) ............ TEI-368, J-25

(and Mrose) ........ J -27

(with Christ, Clark).......J-16 


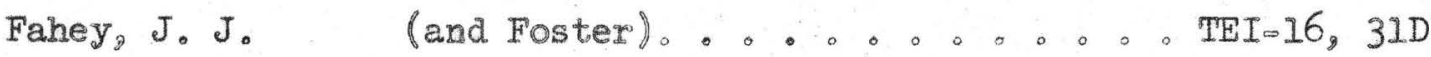

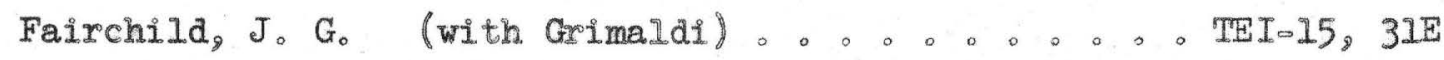

Farley, T.A. (with Senftle, Stieff)。。。。.。.TEI-374

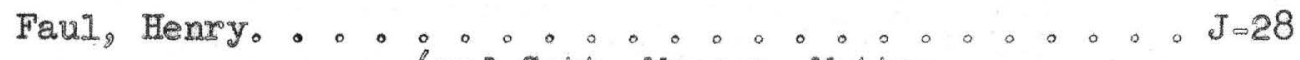

(and Gott, Manger, Mytton,

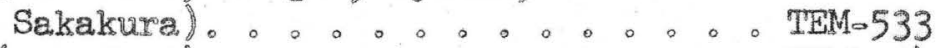

(and Hunt). 0.0 .0 .0 .0354

(and Manger, Sakakura). - . . TEM-239

(and Sakakura). 0.0.0.0.0.TMm 135

- (and Tittle). - . - . . . . . . Jo30

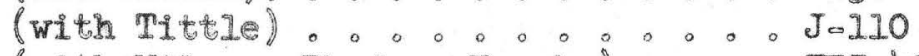

(with WIIson, Rhoden, Vaughn) . . TEI-403

Feegar, JoA。 (with Benson, W. E。, Trites, Beroni)。 TEM-325

Ferguson, D. E. (with Aberdeen, White, Sherwood,

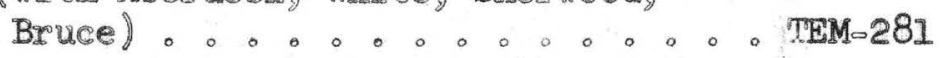

Fetzer, W. G. (and Waulters, Fischer, R. Po) 。 . TEIo89

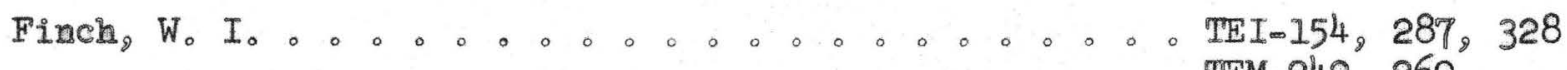

. . . . . . . . . . . TEM-242, 269

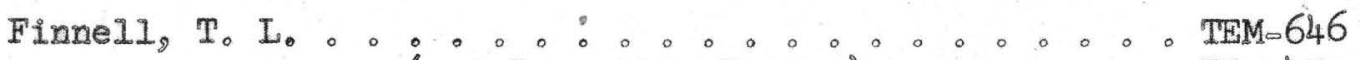

(and Renzetti, Trites). . . . TEM-479

(with Trites) 0.00 .0 .0 TEI-320

(with Trites) 。.०.०.०.。. TEM-540

(with Witkind, McKay, Johnson, D。 H。,

Claus, Johnson, D。 Lo) .....TEM०318 
221

Fischer, R. P. . . . . . . . . TEI- 80, 109, B-936-P, $\mathrm{J}=32,33,3 \mathrm{~L}, \mathrm{OM}-\mathrm{b}$

............... TEM- 48, 156, 203 , $-324$

(and Blackman).......... TEI- 86, 96 (Pt. I)

(and Butler, A. Po) ........ TEM- 38

(and Davis) ......... TEM-196

(and Haff, Rominger)........ J-35

(and Hilpert, Schumacher, Cater,

Strobell, Craig, Phoenix, Trace) . . TEM-276

(and King).......... TEM $7 \mathrm{~A}$

(and MacKallor, Brown, C. W.) .... TEM-205

(and Stokes, Smith, I, E.)..... OM-a

(with Fetzer, Waulters) ...... TEI- 89

(with Hilpert).......... TEM- 77

(with McKelvey, Page, L. R。, Butler,

A. P.) .............. TEI-150, J-67

(with Stokes, Russell, Butler, A.P.) O OM $=1$

Fischer, W. A. ................ TEM-384, 409, 413, $-442$

(and Condon)........... TEM-469, 470, 499

Fix, P, F. ................. TEM-476

Flanagan, F。 J。 (ard Nelson, J. Mo, Warr) ..... TEM-142

(and Senftle)......... TEI-333

Flege, R,F., Jr. (with Vine) ......... TEI-336

Fleischer, Michael.............. TEI- 11, 128

(and Cameron) : : : : TEI- $29,31 \mathrm{~K}$

(and Harder)........... TEI- 7, 10, 14,

- $31 \mathrm{H}, 31 \mathrm{I}, 31 \mathrm{~J}$

(and Rabbitt) .......... TEI - 37, J-36

(with Foster, Stevens, R。 E.,

Grimaldi, Schlecht)....... TEI- 3IA

(with Frondel). ........ TEI-103 
Fletcher, M。H............... TEI-130, 130 Adden-

(and May).......... TEI-120 dum

(and May, Anderson, J.W.). .... T: I-133

(and May, Slavin) ....... TEI-104

(and Warner, E。 R.) ....... TEM-252

(with Grimaldi, May). ..... TeI-219

(with Larsen, Cisney) ....... J-59

(with May). . . . . TEI- 91, 135

Foster, M. D. (and Grimaldi, Stevens, R. E.)...TEI- 2

(and Stevens, $R_{0} E_{0}$ ). ...... T TEI-3IB

(and Stevens, R. E。, Grimaldi,

Schlecht, Fleischer) ..... TEI-3IA

(with Fahey).......... TTI-16, 3ID

Freedman, Jacob................ TEI-346

Freeman, V. I. (with Craig) ........ TEM-209

(with Craig, Holmes, Cadigan,

Mullens, Weir) ......... TEI-180

(with Mullens)......... TEI-34I

Frondel, Clifford. ..............TEI-327

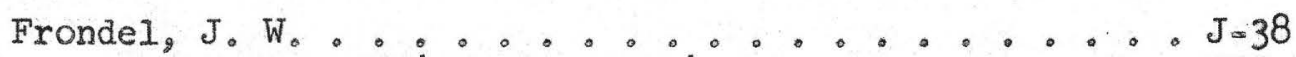

(and Cuttitta) ............... TEI-309, 367

(and Fleischer) ........TEI-103

Fuyat, R. Ko (with Silverman, Weiser). .....TEI-I18 
Garmoe, W. J. (with Cressman, Wilson, Tandy). ... TEI-361

Garrels, R. M. ...................... J-40

Gates, G. I. (w1th Marger) .......... TEM-509

Gault, H. R。.......................... TEI 41 (and Black, Lyons)......... TEI $=25$

Gilbert, C.G. (with Strobell, Sample, Stephens,

H. G.) .................... 632

Gi1. J. R。

(with Hai1) .......... TEI $=272$

(with Ha11) ...................... 446

Gillerman, Eliiot. ............... TEM-675, J-41, 42 (and Whitebread)......... TEI-261

(with Granger).......... TEM-120

(with Granger, Bauer, Lovering, T.G.). TEI-156

Girhard, M. N, (with Stieff, Stern)........ TEI-106, 108

Glass, J.J. (with Hewett)......... J-47

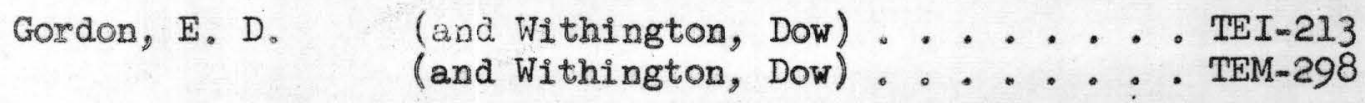

Gosman, R. F. (with Peterson, Swanson, R. W.) ... TEI-375 
224

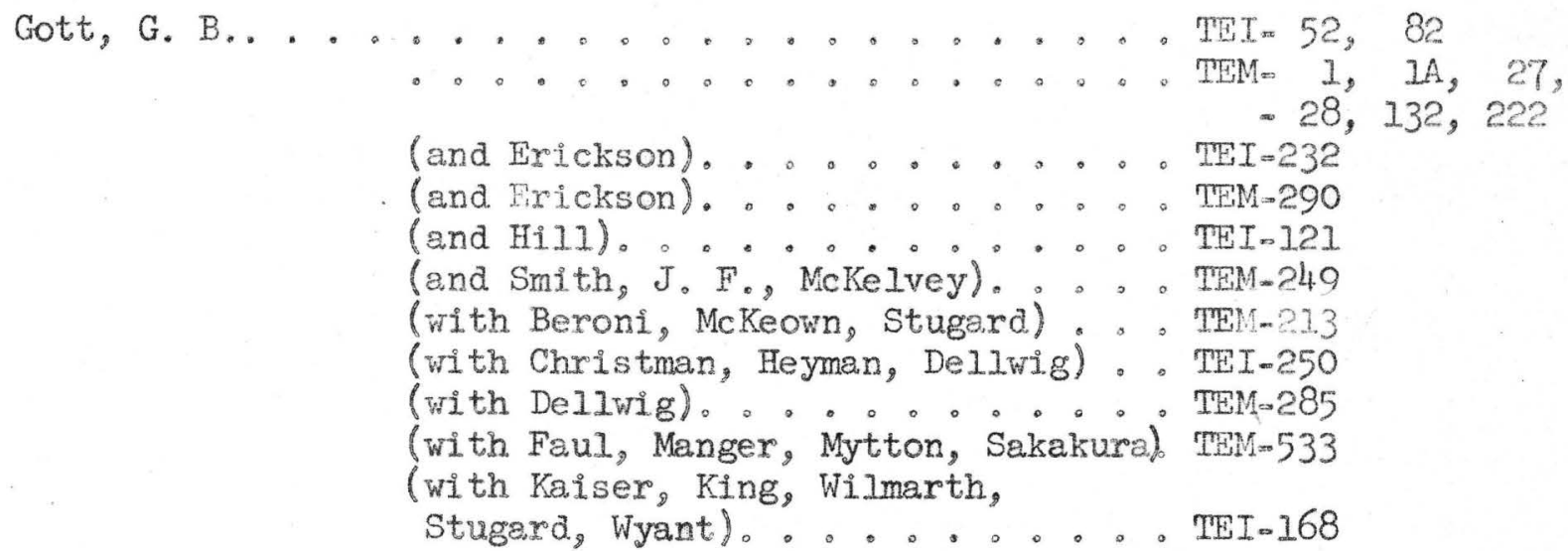

Gottried, David (with Neuerburg).。.。...。。. TEM-709

Gower, H. D。 (with Masursky, Pipiringos) 。... TEI-332

Granger, H. C...................... TEI-227

................ TEM=118, 219, 304

(and Bauer) . . . . . . . TE I 157

(and Bauer) ................ TEM 32, 33, 117,

(and Bauer, Lovering, T. G., $-119,134,146$

Gillerman) 。......... TEI-156

(and Beroni)................. 7, 20

(and Gillerman) . . . . . . TEM-120

(and King). .................... 128, $128 \mathrm{~A}$

(with Beroni, King)........, TEM- 25

(with King) .......... TM- 24

(with Waters).......... IEI-170

Grantz, A. (with Wedow, Bates, Houston, Killeen, Matzo, Nelson, Stejer, West,

Velikanjel.......... TEM-552

Gray, C.H., Jr, (with Carr, Cathcart).....。. TEM=243

(with Cathcart, Blade). ...。. TEM-477

(with Cathcart, Carr, Petersen) 。. TEM-436 
Griffitts, W, R. ................ TEI-249

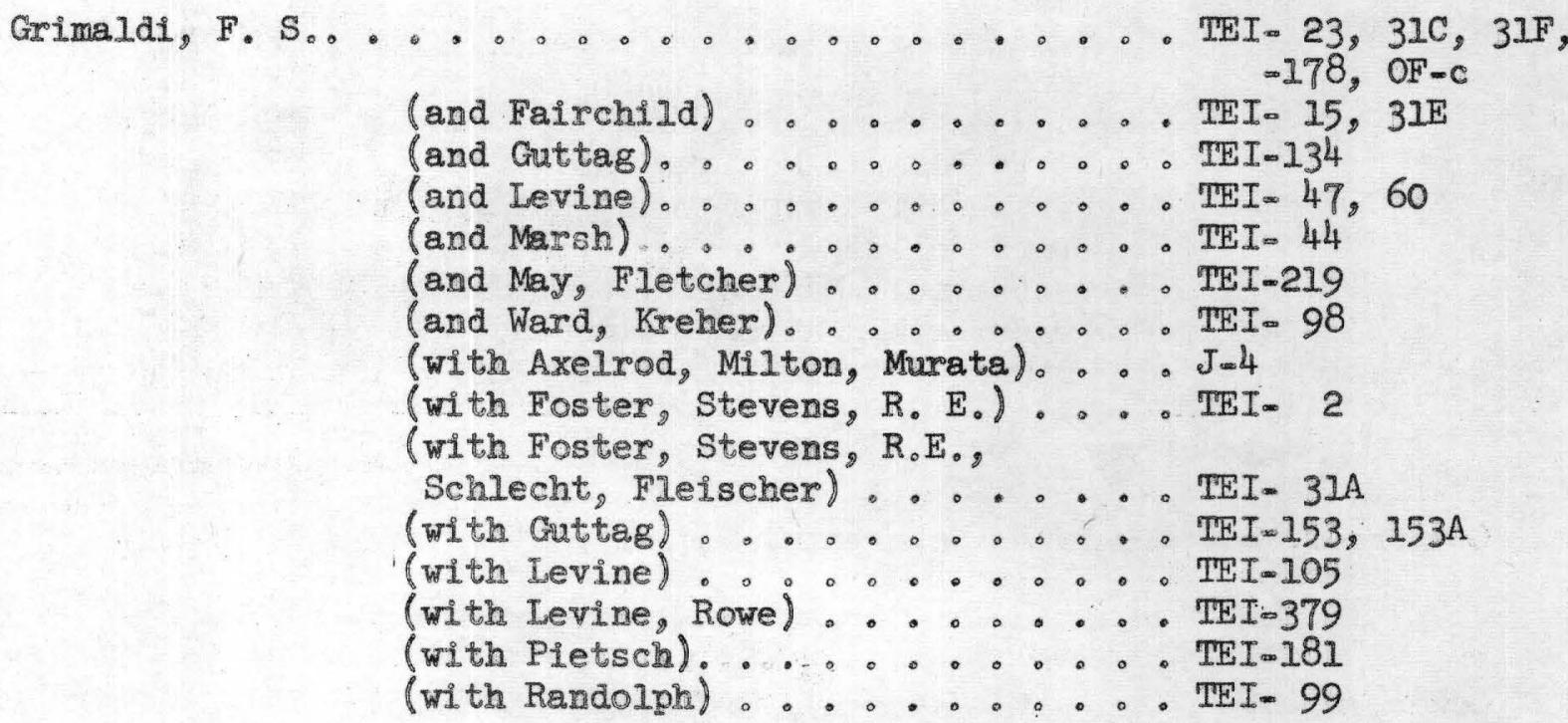

Gualtier1, J.I. ................. TEM-493

(and Emerick)

(with Emerick)。........ TEM $625,683,684$, $.685,689$

Gude, A, J, 3rd (and McKeown) ...........TEM-292

(with Adams, Beroni)....... TEM-154

(with MeKeown). ........TEM-308

(with Roberts)..........TEM-140, 229

Guinan, W. A................... TEM= 71,86

Gulbrandsen, R. A. (and McLaughlin, Honkala, Clabaugh, Krauskopf) : .......... TEI-260 (with McKelvey, Armstrong, Campbeli). TEI-187

Guttag, No W。 (and Grimaldi)...........TEI-153, 153A (with Grimaldi) ......... TEI-134 


\section{6}

$-\mathrm{H}_{0}$

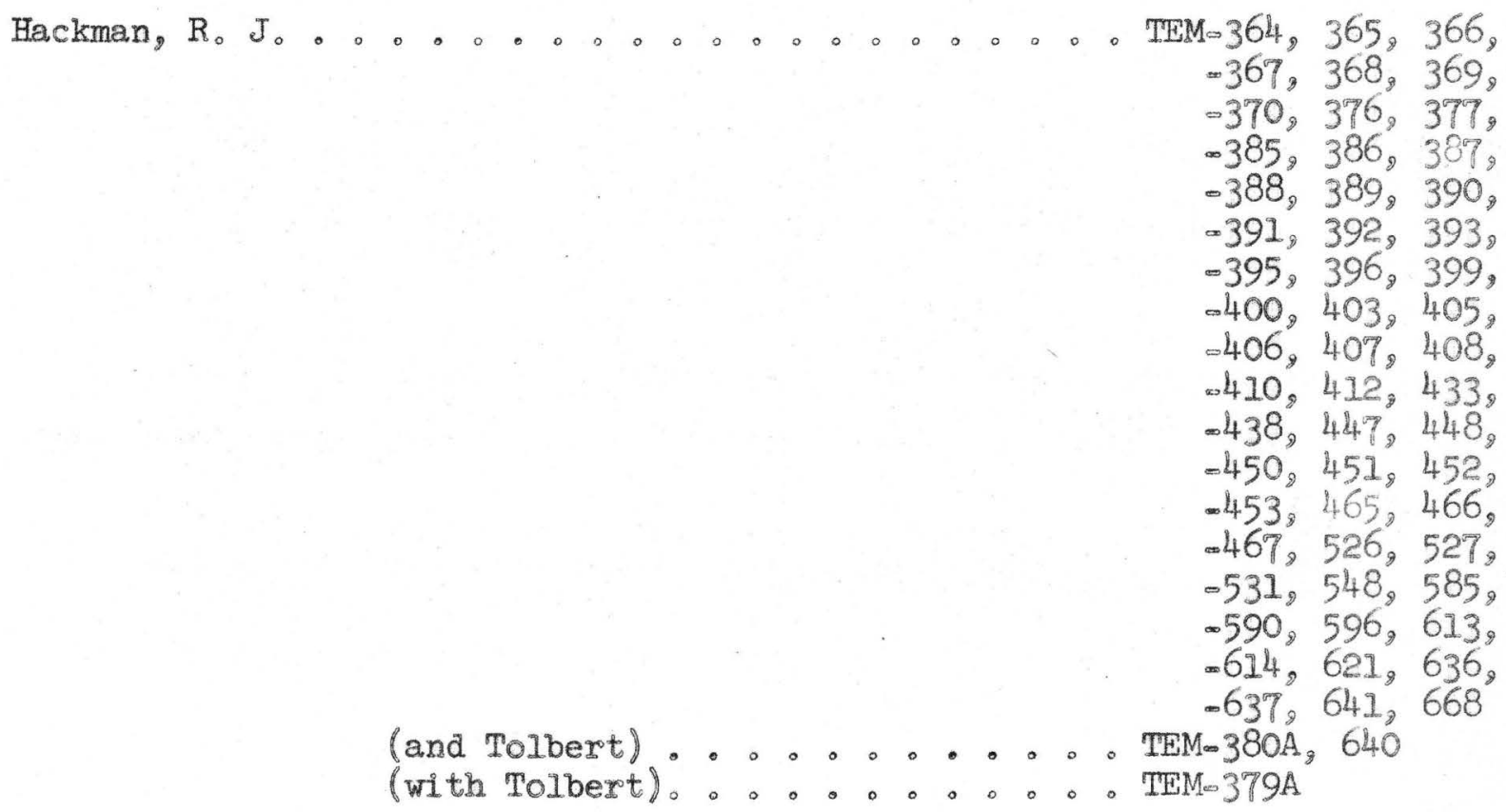

Haff, J. C. (with Fischer, $R_{0} P_{0}$, Rominger)。。 J-35

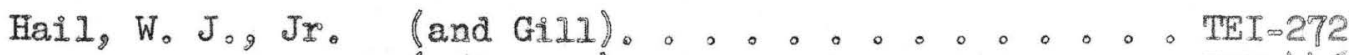

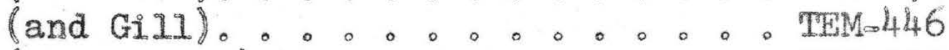
(with Mapel).。.

(with MapeI)。。.。.。. . . TEM-432

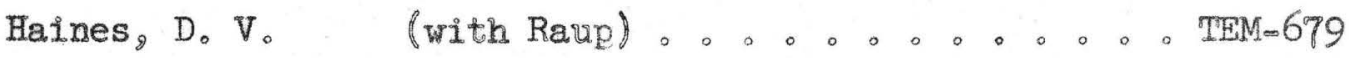

Ha.11, M。 L。 (and Butlex, A. P.) 。..。०。.TEI-242

Ha11, R。 B。 (and Moore, F。 B。)。.。.。.。.TEM०108

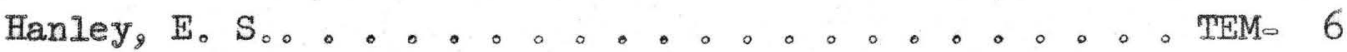


Hanley, J. B.............. J- . . . . . . (and Heinrich, Page, L. R.) : : : P-227

Harder, J。 0 .

(and Reed). ......... TEI- 6

(and Stead) ................. TEI $2 I$

(and Wyant) ............... TEI 4

(with Fleischer). . . . . . TEI $7,10,14$, $-31 \mathrm{H}, 31 \mathrm{I}, 31 \mathrm{~J}$

Harrison, H. C. (with Larsen, Keevil) ....... J-60

Harrison, J. E................ TEM-291, J-46

(and Ieonard) . . . . . . TEM-153

(and Wells)........... TEI-295

(with Sims, Moore, F, B.) ..... TEM=520

(with Wells).......... TEI-305

Hass, W. H. (with Conant, Brown, A。). ...。TEI= 62

Hawkes, H. E。 . . . . . . . ....... TEI 96 (Pt。 3)

Heinrich, E. Wm. (with Hanley, J。B., Page, L. R。) 。. P-227

Hemphi 11, W. R. ................ TEM-530, 543, 550, $-589,599,612$, $-650,654,657$

Henbest, L. G. (with Love, Denson) ........ OM-g

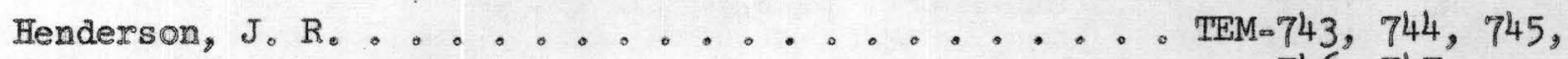
$-746,747$

(and Moxham)...........TEM-605 
Hendricks, T. A. . . . . . . . . . . . TEM-43, $44,45,47$

Hewett, D, F. . . . . . . . . . . . TEM= 144 (and Glass) . . . . . . . J J 47

Heyman, A. M. (with Christman, Dellwig, Gott)。.TEI=250

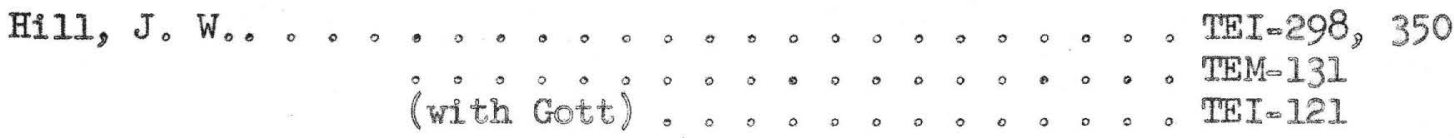

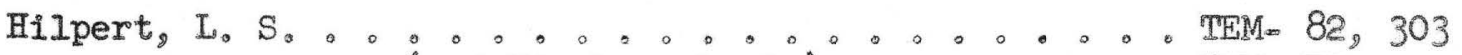

(and Fisches, R。 Po).。. . . . . TEM- 77

(with Bush, Thace). . . . . . TEI 116

(with Fischer, R。P., Schumacher,

Cater, Strobel1, Craig, Phoenix,

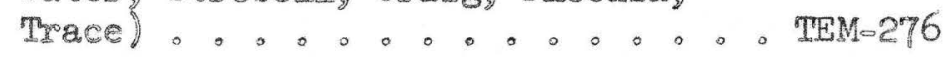

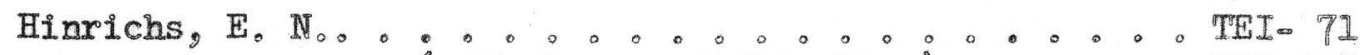

(with Moore, F。 Bt, King) 。. O. TEM=215

(with Smith, J.F, Luedke) 。。०。TEI-203

(with Smith, J.Fo, Huff, Iuedke) 。 TEM-538

Holmes, C.N.。. . . . . . . . . . . . . J

(with Craig) $0.00 \div 0.0 .18$

(with Craig, Cadigan, Freeman,

Muliens, Weir) . . . . . TEI-180

Holser, W. To。

(with Warner, L。 A。 Wilmarth,

Cameron) ........... TEI-137, J-50

Honkala, F。 S。

(with Gulbrandsen, McLaughiin,

Clabaugh, Krauskopf) 0.0 TEI-260

(with Swanson, R.W. Klepper, Loweli,

Cressman, Bostwick, Payne, Ruppe1). TEI 186 
$\begin{aligned} & \text { Hoppin, R. A. } \text { (with McKelvey, Smith, L. E., } \\ & \text { Armstrong) } 0 \text { TEI-184 } \\ & \text { (with O'Malley, Davidson, Sheldon) : TEI-188 }\end{aligned}$

Horx, C.A. (with Exickson, R, L。, Myers).... TEM-513

Hosford, G. F. (with McKelvey, Smith, L. E, Kinney, Huddle, Sears, Sprouse, Stewart, M. D.) ........ TEI-185

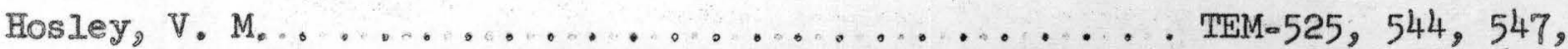
$-584,598,638$,

(with Bates, C. E.)........ TEM-660

Houser, F. N. (with Cathcart) ......... J-15

(with Overstreet, McKelvey)..... TEM-2I

Houser, S, S. (with Curtis).......... TEI-30I

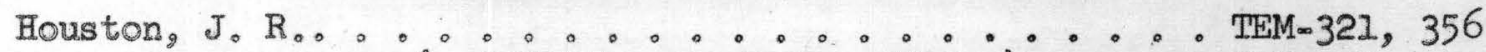

(and Velikanje, Bates, Wedow). . . TEI-293

(with Wedow, Bates, Grantz, Killeen,

Matzko, Nelson, Stejer, Velikanje,

West) ............. TEM-552

Hubbard, Ho A。 (with Mullens, T. E.). ...... TEM-537

Huddle, J. W。 (and McCann) .......... OM-c

(and Mapel, McCann)........ OM-d

(with McKelvey, Smith, I。 E。,

Kinney, Hosford, Sears, Sprouse,

Stewart, M. D.) ........ TEI-185 


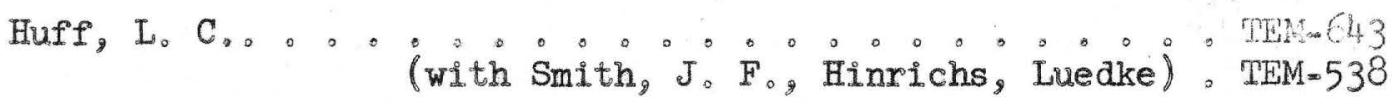

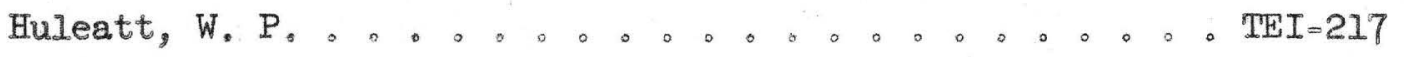

Hunt, C. B (and others). . . . . . . . OM

(with Faul)

$=I=$

Icke, H. M, (with Bell, H.) , . . . 。 。 TEM=112

Jackson, W, H. 。 。 。 。 。 。 。 。 . 。 。 TEM-627, 710

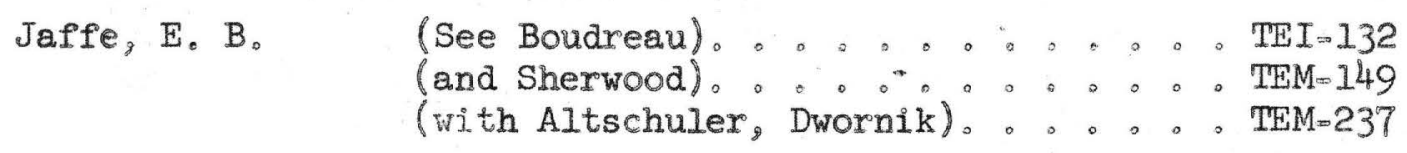

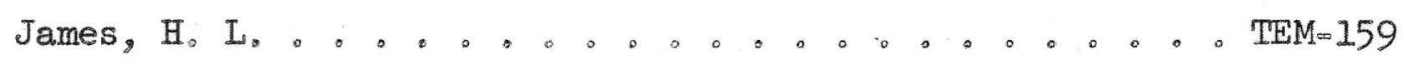


231

Jobin, D. A. ................... TEI-2I4

.................... TEM-262, 263, 264,

(and Schessler) ......... TEM- 481

(with Brasher). ........ TEM-186, 189, 202

(with McKay)........... TEM- 705

Joesting, $H_{\text {, }} \mathrm{R}_{0}$. . . ................. TEM-100

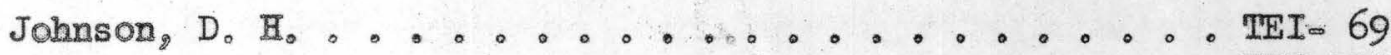

○.............. TEM-125

(with Wilmarth) ......... TEI-158, 172

(with Witkind, Thaden, Claus, Lough): . TEI-204

(with Witkind, McKay, Finnell, Claus,

Johnson, D。 $\left.I_{0}\right)_{0} \ldots \ldots$............ TEM-318

Johnson, $D_{0}$ I. (with Witkind, McKay, Johnson, D. H.,

Finne11, Claus)。........ TEM-318

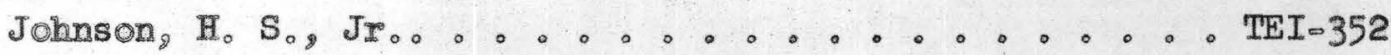

Johnson, $R$, $W_{0} \ldots \ldots \ldots$............................ 748 (and Moxham) .................

(with Moxham) ......... TEM-644

Jones, R.J. (with Sheldon, Cressman, Smart, Waring,

$\mathrm{R}_{0} \mathrm{G}_{0}$, Thompson, $\mathrm{M}_{0} \mathrm{E}_{0}$, Weiser, $\mathrm{J}_{\circ} \mathrm{D}_{\circ}$,

Peircel............. OF $\triangle \mathrm{m}$

Jones, R. S。 (with Swanson, R. Wo, Cressman,

Replogle). ..........TEI-362 
Kaiser, E, P. ............... TEM=145, 210, 216,

(and King, Wilmarth, Stugard, Wyant,

Gott)........... TEI 168

(with Wyant, Stugard) ....... TEI-169

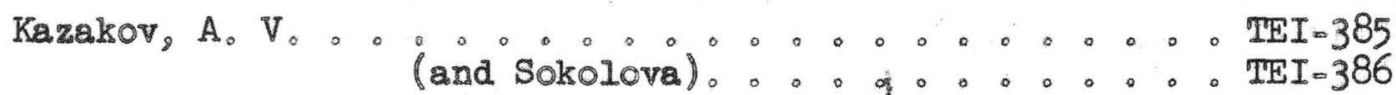

Keevi], N。B。 (with Larsen, Harrison, $H_{0} C_{0}$ ). ....... J 60

Keiser, H。 D. ............... TEM- 66

Kellagher, Richord ................ TEI=371

Keller, G. V. ................ TEM-608

Kennedy, G. C.................. OF $F_{x d}$

Kent, K, B.................. TEM-651, 658

(and Condon).

Ketner, K. B. ................. TEM-168, 233, 315,

(with Cathcart, Blade, Davidson)。。TEI-265

(with Cathcart, Davidson, Dutro,

Petersen, Tiliman, Pratt) . .... TEM-138

(with Davidson, Cathcart) ...... TEM-234 
Killeen, P. L. (and Ordway).......... TEI- 27 (and White, M. G.). . . . . . TEI- 42 (with Butler, A. P., Page, G. Bo, Rubey) ............. TEI 35 (with Wedow, Bates, Grantz, Houston,

Matzko, Nelson, West, Stejer, Velikanje) .......... TEM-552 (with White, M. G.) ....... TEI- 45 (Pt. 1),

King, R. U.................. TEI 59

$\ldots \ldots \ldots \ldots$. . . . . . . $3,4,5,13$,

(and Granger) ......... TEM- 24 $-22,102$

(and Leonard, Moore, F. B., Pierson). . TEM=173

(and Roberts) .......... TEM- 11, 12

(with Adams)......... TEM- 29

(with Beroni) .......... TEM-133

(with Beroni, Granger)....... TEM- 25

(with Fischer, R, P.) ....... TEM- $7 \mathrm{~A}$

(with Granger)......... TEM-128, 128A

(with Kaiser, Wilmarth, Stugard, Wyant, Gott) ......... TEI-168

(with Moore, F。 Bo, Hinrichs) . . . TEM-215

Kinney, D。M...................... 67, OM-f (with McKelvey, Smith, L. E., Huddle,

Hosford, Sears, Sprouse,

Stewart, M. D.)........ TEI-185

Kinser, C. A. . . i

(with Cuttitta)........ TEI-326

Klemic, Harry (and Baker) ......... TEM-503

(with McKeown). ...... TEI-317, 383

(with McKeown)........ TEM-55I

(with McKeown, Choquette) ......TEI-382

Kleinhampl, F. J. (with Pierson, Weeks, W. F。)..... IEI-306 
234
Klepper, $M_{0} R_{0} \ldots \circ \ldots \ldots \ldots$. . . . . . . TEM 3I, 127 (with Swanson, R。 Wo, Lowell, Honkala, Cressman, Bostwick, Payne, Ruppel) 。 。TEI-186

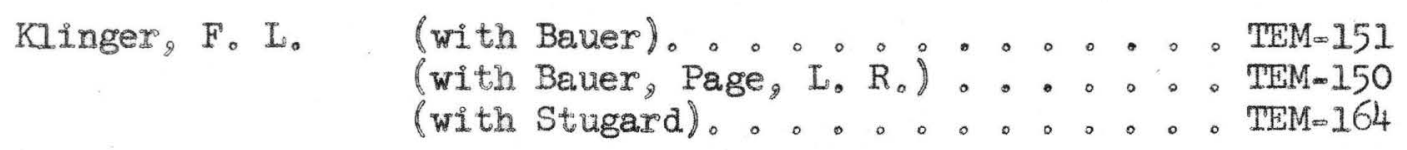

Koczy, Gerta ................ TEM-305

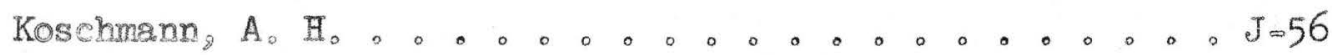

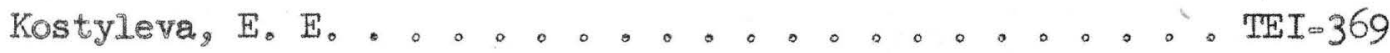

Krauskopf, K. B. 。 . . . . . . . . . . . J-57

(with Gulbrandsen, McLaughlin,

Honkala, Clabaugh) 。. . . . TEI-260

Krehex, Ruth (with Grimaldi, Ward) . . . . . TEI 98

Krummel, W. J。 (and Lewis) ......... TEM-714

Kummel, Bernard.... 。 ...。. ..... J J 58

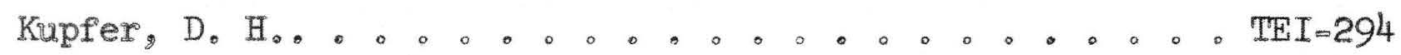


Lang, A. J., Jr。 (and Redden)............ TEI-155

Larsen, E. S., Jr. (and Fletcher, Cisney)....... J-59

(and Keevil, Harrison, H. C.) ....J. J-60

(and Waring, C. L., Berman, J.) .... J-6I

(with Meyrowitz).........J-70

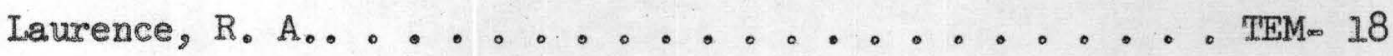

Leonard, B. F。........................ TEM21, J-62 (with Harrison)

(with King, Moore, F。 B., Pierson). . T TEI-173

Levine, Harry (and Grimaldi).......... TEI-105

(and Rowe, Grimaldi)....... TEI-379

(with Grimaldi) ........... TEI- 47,60

(with Phair). ........ TEI-262

Lewis, R。 Q. ............... TEM-712

(and Reitan)

(with Krumme1)........... TEM-714

(with Trimble)........... TEI-32I

(with Trimble).......... TEM-535

Lough, C.F。 (with Witkind, Thaden)....... TEM-492, 536, 577 (with Witkind, Thaden, Johnson, Claus). TEI-204

Love, J. D. ........................ TEI-315, C-176 .................. 122, 283, 708 (and Henbest, Denson) ....... OM-g 


$$
236
$$

Lovering, T. G. ............... TEI 169, 174, 230, $-276$

(with Granger, Bauer, Gillerman)。. OTEImI56

(with Walker) 。........ TEI-229

Lovering, To S。 (with Rabbitt, Rubey, Butler, A。 Po,

McKelvey). . . . . . . . TEI-206

Lowell, $W_{0} R_{0}$ 。 。 . . . . . . . . . . TEI-312, OF-e (with Swanson, R。Wo, Klepper, Honkala,

Cressman, Bostwick, Payne, Ruppe1). . . TEI-186

Luedke, R. G. ............... OF $\circ$ f

(and Shoemaker) ......... TEM- 301

(with Shoemaker)。....... 。 TEI-279

(with Smith, J。F。; Hinrichs) 。...TEI-203

(with Smith, J。F。, Hinrichs, Huff) 。 TEM=538

Lundine, Shirley (with Altschuler, Berman, Owens,

Delevaux)........... TEM $\approx 604$

Lutz, Katherine (with McKelvey, Cathcart, Altschuler,

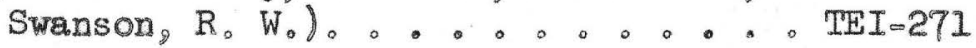

Lyons, J.B. (with Gault, Black) ....... TEI- 25

(with Robinson, Wedow) ...... TEI 26 
-Mc -

McCann, F. T.

(with Huddle) . . . . . .... OM-c

(with Huddle, Mapel)......... OM-a

McGinley, F, E. (with Cathcart) ..........TEM-464, 505

MacKallor, J.A. (with Fischer, R. P., Brown, C, N.) . . TEM-205

McKay, E. J. , ................... . TEI 2 . . . . . . . . . .

. . . . . . . . TEM-271, 691

(and Jobin) ........................... TO5

(with Troyer, Solster). ...... TEM-572

(with Troyer, Soister, Wallace, S. R.). TEI-345

(with Witkind, Johnson, D. H.,

Finne11, Claus, Johnson, D. I.)...TEM-318

McKee, E。 D.

(and Weir).

TEI-269

McKelvey, V. E。 . . . . . . . . . . . . TEI $77,131,199$, $-208, \mathrm{OF}-\mathrm{g}, \mathrm{J}-64$ TEM- 194

(and Armstrong, Gulbrandsen, Campbeli).TEI-187

(and Cathcart). . . . ..... TEI 94

(and Cathcart, Altschuler, Swanson,

R. W. Lutz) 。. ........ TEI-271

(and Cathcart, Worthing). : : . TEM-236

(and Davidson, O'Malley, Smith, L. E。,

Armstrong, Sheldon). ........ TEI-183

(and Nelson, J, M. ) . . . . . J 66

(and Page, L。 Ro, Fischer, R. Po,

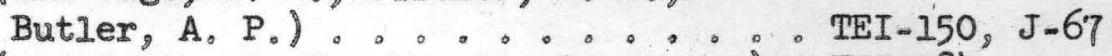

(and Smith, I, E。, Hoppin, Armstrong), TEI-184

(and Smith, L. E., Kinney, Huddle,

Hosford, Sears, Sprouse,

Stewart, $\left.M_{0} D_{0}\right) .0$. $0 . \ldots$ TEI 185

(and Swanson, $R_{0} W_{0}$ ) 。...... TEI-111

(and Swanson, R.W, Sheldon) . . TEI-263

(with Gott, Smith, J. F.) ...... TEM-249

(with Overstreet, Houser) ....... TEM- 21

(with Rabbitt, Rubey, Butler, A. P.,

Lovering, To $\left.S_{0}\right)$ ? TEI-206

(with Swanson, R. W. Shéldon): : :TEI-246 
238

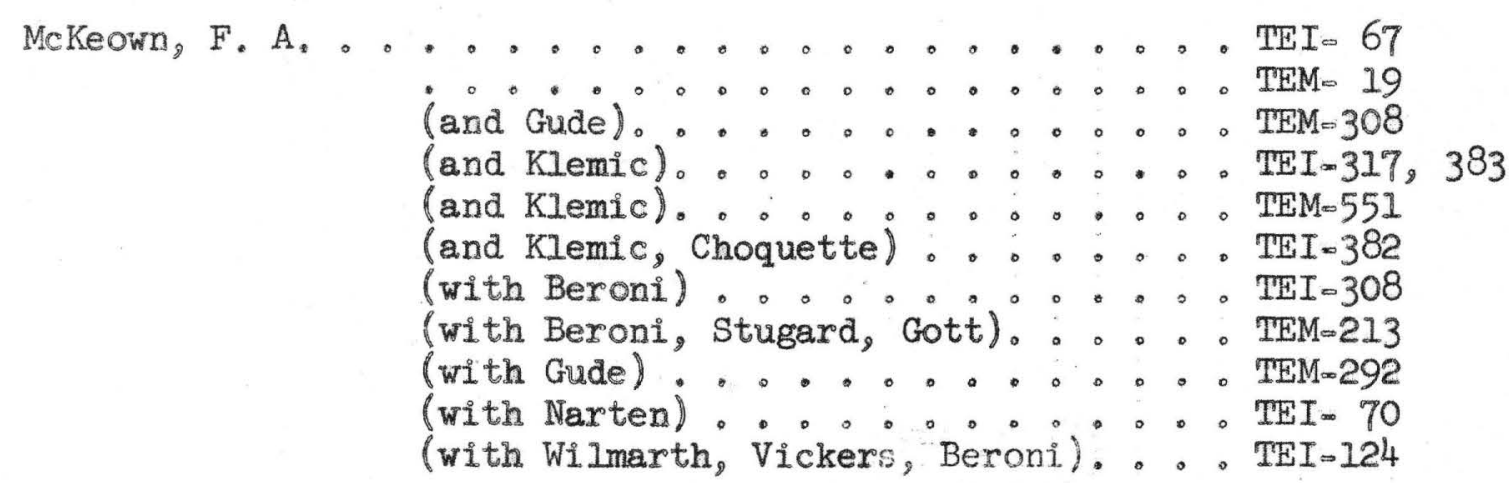

Mclaughlin, K. P. (with Gulbrandsen, Honkala, Clabaugh,

Krauskopf) ............ TII $=260$

McNeal, R. P......................TEM-107, 129, 141

$-M_{-\infty}$

Mackin, J. H. . , 。. . . . ....... . TEM- 473

(and Schmidt) ......... TEM=602

Madsen, J.W.................. TEM-576, 631

Main, F.H. (with Chesterman) ........ TEI-24, 30

Manger, G. E。 (and Gates)........... TEM=509

(with Faul, Gott, Mytton, Sakakura) 。TEM=533

(with Faul, Sakakura).......TEM-239

Mape1, W。 J.

(and Hail)........... TEI-339

(and Hail). .......... TEM-432

(with Huddle, McCann)......... OM-d 
Marsh, CoA。 (with Grimaldi) ........ TEI-44

Masursky, Harold (and Pipiringos). . . . .... TEM-601 (and Pipiringos, Gower) ..... TEI-332

Matzko, J。 J.. ................ TEI- $45 \mathrm{C}$

(with Nelson, West)........TTI-292

(with Wedow) . . . ..... TEI- 38

(with Wedow, Bates, Grantz, Houston,

Killeen, Nelson, Stejer, West,

Velikanje) . . . . . . . . TEM-552

(with West) ............ TEM 45 (Pt。2), .49

MaxwelI, C.H。 (with Sheridan, Collier)。.... . TEI-302

May, Irving

(and Fletcher). . . . . . . TEI 91 , 135

(with Fletcher) ......... TEI-120

(with Fletcher, Anderson, J。 Wo). . . TEI-133

(with Fletcher, Slavin) ...... TEI-104

(with Grimaldi, Fletcher) ...... TEI-219

Mela, Henry, Jr。 (with Waring) . ........ TEI-239

Mertie, Jo Bo, J $x_{0} \ldots \ldots \ldots \ldots \ldots$. . . . . . . . 23, 248

Meschter, $D_{0} Y_{0} \ldots \ldots \ldots \ldots \ldots \ldots \ldots$. . . . . . . . TE6

Meuschke, Jo Lo. . . . . . . . . . . TEM-344, 359

(and Moxham).

(and Moxham, Bortner) . . . . . TEM-673, 678 
240

Meyrowitz, Robert.

(and Larsen). 0.0 .0 .0 .070

(with Breger, Deul) 。. . . . T TEI-388

(with Breger, Deul, Rubinstein) . . TEI-389

(with Breger, Warr) 。. ....... TEI-372

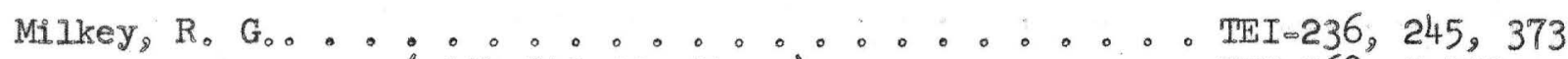

(with Stieff, Stern)。....... TEI-268, J-102

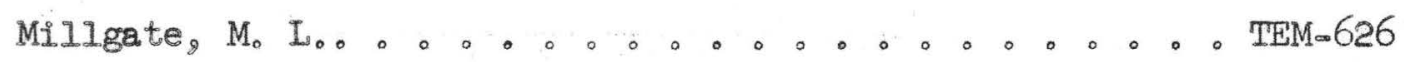

Milton, Charles (with Axelrod, Grimaldi, Murata)。. . Jo4

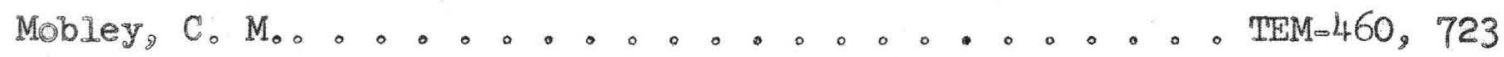

Moench, R. H。 (with Sims, Drake). .....。。 TEI-304

Moore, F。B. (and Butler, C. R。) . 。 . . . TEM-198

(and Cavender). 0.0 .0 .0 .0 TEI-228, J- 72

(and Ha11, R. B.) ........ TEM- 108

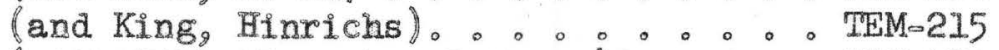

(with King, Leonard, Pierson) . . . TEI-173

(with Sims, Harrison)....... TEM-520

Moore, G. W. ...................... TEI-235

(and Stephens, J. Go)

(with Vine).。. 0.0 .0 .0 . 281

(with Vine)

(with Vine, Bachman, Read)。....TEI-24I

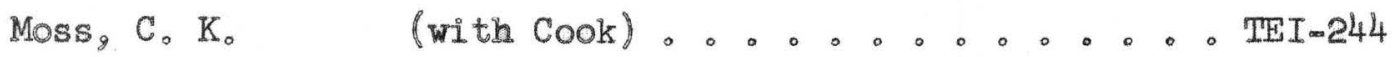


241

Moxham, R。M

Mrose, M。E。

Mullens, T. E。

Murata, $K_{\circ}$ J.

Myers, A。R。

Myers, A。 T。 (with Evans)......... J-27

(and Freeman) .......... TEI-34I (and Hubbard) .......... TEM-537 (with Craig, Holmes, Cadigan, Freeman,

Weir)............. TEI-180

(and Cisney, Stieff, Zworykin)..... TEI-107 (with Axelrod, Grimaldi, Milton).... J 4

(with Eicher) ........ TEM-727

(and Barnett) ......... TEI-179

(with Erickson, Horr) ..... TEM-513

Myers, $W_{0} B_{0} \ldots \ldots \ldots \ldots$ TEI-259

Mytton, J. W。 (with Faul, Gott, Manger, Sakakura)...TEM-533 
Narten, P. F.................... TEM-670

(and Crawford, Butler, A. P.) . . . TEM-240 (and McKeown) 。........ TEI-70 (and Starrett)................ TEM 580 (with Nelson, J.M.)....... TEI- 68

Nelson, A. E. (and Tolbert) .......... TEM-320

(and West, Matzko). . ...... TEI-292

(with Moxham) .......... TEI 74A, 190, 191

(with Tolbert).......... THM-319

(with Wedow, Bates, Grantz, Houston,

Killeen, Matzko, Stejer, Velikanje,

West)........... TEM 5552

(with White, M. G.)

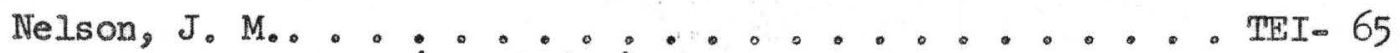

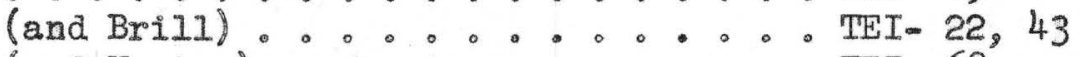

(and Narten).......... TEI 68

(and Stratton)................ TEI 34

(with Bril1, Prouty)....... TEI- 8

(with Flanagan, Warr) . . . . TEM-142

(with McKelvey)......... J-66

(with Slaughter). . . . . . TEI-20

Nelson, R. A................................. (and Sharp, Stead). . . . . TEM-147

Neverburg, G. J. (and Gottrried) ........... TEM-709

Newman, W. L...................。 TEM-187

(with Shoemaker).

(with Stephens).......... TEM-201

Nolan, T. B. ........................ $40,51,55$, 
243

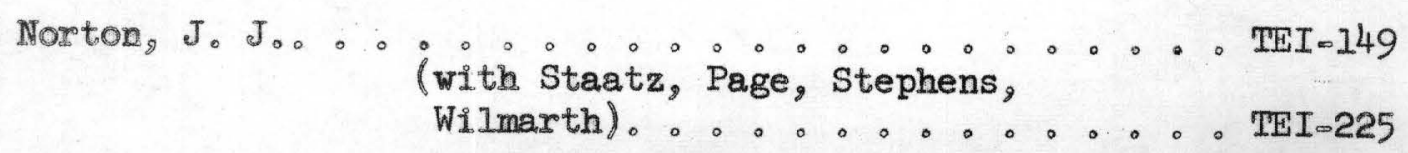

Okerlund, $M_{0} D_{0} \ldots \ldots \ldots \ldots \ldots$................. TEM-582

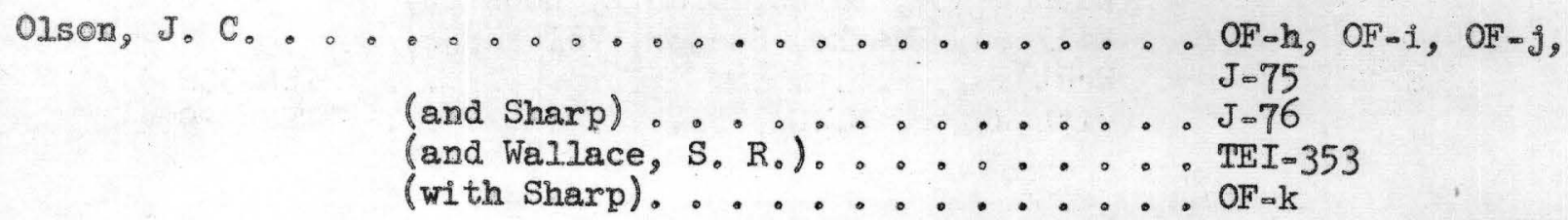

O'Ma1ley, F。W。 (and Davidson, Hoppin, Sheldon) . . TEI-188 (with McKelvey, Davidson, Smith, L. E.,

Armstrong, Sheldon).........TEI-183

Onoda, Kiyoko (with Phair)(See also Shimamoto)... .TEI-144

(with Phair)........... TEM 173

Ordway, $R_{0} J_{0}$ (with Killeen). ..........TEI- 27

Oxkild, P。P.。................. TEM-528, 532, 542, $-545,591,594$, $-600,617,642$, $-655,659,665$

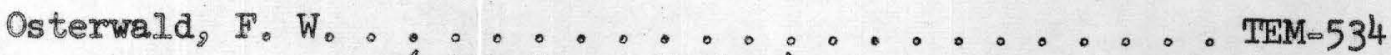

(with Sims, Tooker) . . . . . . TEI-125

(with Staatz) .......... TEI-252 
244

O'Sullivan, $R$, B. (with Bachman, Baltz) 。.。。。.。.TEI-198

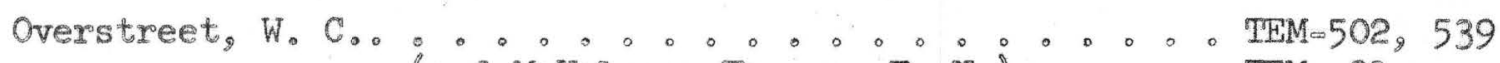

(and McKelvey, Houser, $F_{0} N_{0}$ ) 。. 0 TEM- 21

(and Theobald)。

fand Theobald, White, A.M. Cuppels,

Caldwe11, Whit1ow) . . . . . TEI-349

Owens, Jo P. (and Berman, Altschuler). . 。. . TEI-316 (with Altschuler, Berman, Delevaux,

Lundine) $* 0.0,0 ., 0.0$ TEM 604

Page, G。 B. (with Butler, A。 P., Killeen, Rubey)。 TTEI- 35

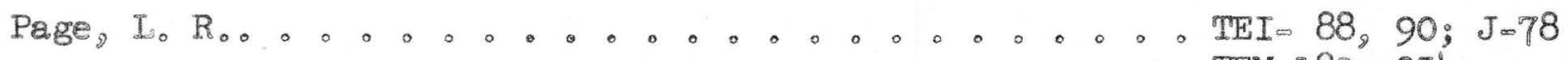

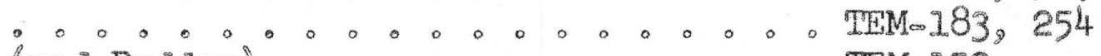

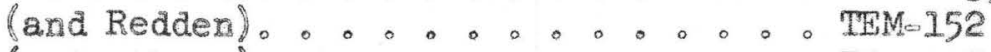

(and others). . . . . . . . T TEI-355

(with Baver, Kilinger).。. 0.0 TEM-150

(with Hanley, Heinxich, $\mathrm{E}_{\text {。 }} \mathrm{Wm}_{\mathrm{O}}$ ) 。

(with McKelvey, Fischer, R。 Po,

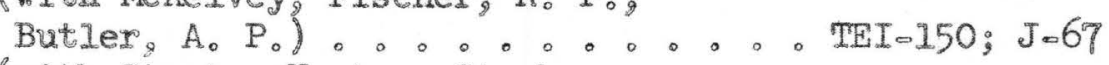

(with Startz, Norton, Stephens,

WiImarth)

Payne, O.A. (with Swanson, R.Wo, Klepper, LowelI,

Honkala, Cressman, Bostwick, Ruppel). TEI-186 
Peirce, $H_{0} W_{0}$ (with Davidson, Smart, Weiser)。。TIEI-365

(with Sheldon, Cressman, Smart,

Waring, $R_{0} G_{0}$, Thompson, $M_{0} E_{0}$,

Weiser, Jones, R。 Jol。 ..... OF $-m$

(with Sheldon, Warner, M。 $A_{0}$,

Thompson, Mo $E_{0}$ ) 。......TEI-364

(with Swanson, R. Wo , Waxing, $R_{0} G_{0}$ ?

Warner, Mo Ao, Smart) . . . . . OF $-p$

Petersen, Ro Go .............. TEI 264

०............... TEM-23I

(with Cathcart, Carro, Gray): : TEM-436

(with Cathcart, Davidson, Dutro,

Ketrex, Tildmax, Pratt)。 . . . . TEM-138

Peterson, JoA. (and Gosman, Swanson, R。W.). D. TEI-375 (with Cheney, Sheldon, Smart,

Waring, $R_{0} G_{0}$, Warner, $\left.M_{0} A_{0}\right)$. . . OF $=a$

Phair, George. . . . ......... TEI-247

(and Levine).......... TEI-262

(and Onoda) ...........TEI-144

(and Onoda) .......... TEM-173

(with Sims)........... TEI-3II

Phoenix, $D_{0} A_{0}$. . . . . . . . . . . 。 TEI-161

... . . . . . . . TEM- 99, 109, 137,

$-270$

(with Cater, Craig). .......TEI-110

(with Fischer, R. Po, HiIpert,

Schumacher, Cater, Strobell,

Craig, Trace). . . . . . . TEM-276

(with Stokes) .......... O $\mathrm{M}_{-\mathrm{j}}$

Pierson, C. T. (and Burbank, Singewald). ..... J $=81$

(and Singewald)

(and Weeks, Wo Fo, KIeInbampI)... TEI-306

(with Buxbank). 。 . . . . . TEM-310

(with King, Leonard, Moore, F。 Bo)。 . TEI=173

(with Singewald, Wilmarth, Vickers) 。TEM-224 
246

Pietsch, Audrey (and Grimaldi).。. . . . . . . TEI*181

Pipiringos, G, No (with Masursky) . . .*....。. TEMm601 (with Masursiry, Gower). ..., . TEI 332

Portnov, A. I. ...., .............., TEI 324

Pratt, J. B. (with Cathcart, Davidson, Drtro, Ketner, Petersen, Tillman) : *.TEM-138

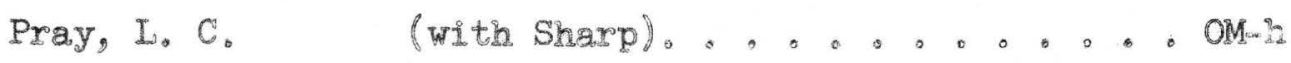

Prouty, C. E. (with Bril1, NeIson, J. M.). . . . TEI 8

$=\mathrm{R}$.

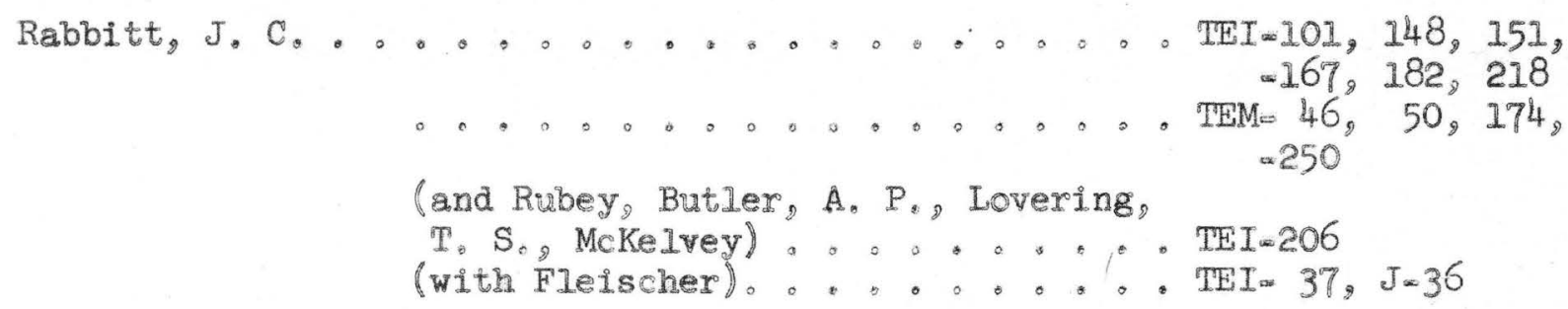

Randolph, R, B, (and Grimaldi)., o. ., , . TEI- 99

Raup, R. B, Jr. 
$\begin{aligned} \text { Ray, R. G. ........................ } & -371,383,401 \\ & 402,404,439 \\ & 440,441,468, \\ & -500,501,523 \\ & -524\end{aligned}$

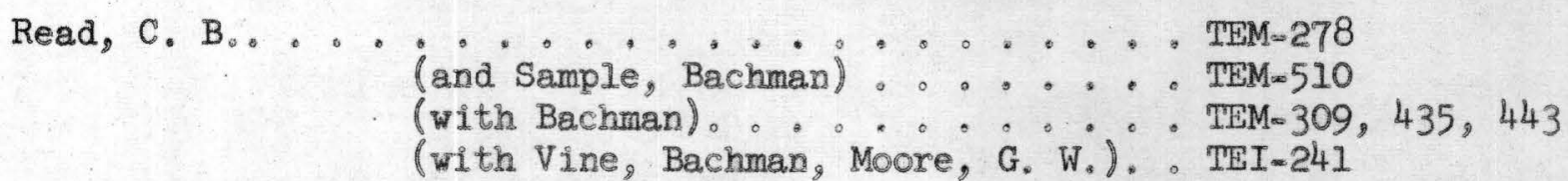

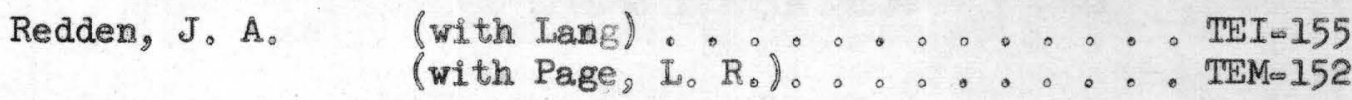

Reed, J. C. (with Harder) ......... TEI 6

Reinhardt, P.W. (with Stead, Balsley, Moxham)....TEM-508

Reitan, $\mathrm{P}_{0} \mathrm{H}_{0}$ (with Lewis). ......... TEM-713

Renzetti, B. I. (with Finnel1, Trites)。 . . . . TEM-479

Replogle, B. Ko (with Swanson, R。 Wo, Cressman, Jones) ............... TEI 362

Rhoden, V. C. (with Wilson, Vaughn, Faul).... TEI-403

Riley, I. B。 (and Shoemaker) .........TEI-278

Roach, C。 $\mathrm{H}_{0} \ldots \ldots \ldots \ldots \ldots \ldots$........... TEM $688,717,718$, 
Robeck, R。C.

(and Brown, A.) ......... TEI- 63

(and Conant)............ TEI 64

Roberts, W. A. (and Gude). . . . . . . TEM-140, 229

(with King) .......... TEM- 11, 12

Robinson, G, D, (and Wedow, Lyons). . . . . . TEI- 26

Rodríguez,

Carlos Ponte (with Wyant, Sharp).... . . . TEI-222

Rogers, A. S................ . TEM-171 (with Bell, K. G.). . . . . . TEI- 84

Rominger, J, F. (with Fischer, R, P., Haff) . . . . J-35

Rosenblum, S, (with Becraft)........... J-7

Rosholt, J。N, Jr..................... TEI-3I8

Ross, Malcolm (with Dwornik)........ TEM-471

Rove, O.N..................... TEI 33 , J-8I

Rowe, J. J.................... TEM-316

(with Conant) $\ldots$ TEM-649

(with Levine, Grimaldi) . .... TEI-379 
Rubey, W. W。

(with Butlex, A。Po, Killeen,

Page, Go Bo o........ TEIm 35

(with Rabbitt, Butler, $A_{0}$ P。?

Lovering, T.S, McKeIvey) . . . . TEI-206

Rubinstein, S。 (with Bregex, Deul, Meyrowitz)....TEI-389

Ruppel, E。T. (with Swanson, R。Wo, Klepper,

Lowe 11, Honkala, Cressman,

Bostwick, Paynel ........ TEI-186

Russe1, R, T. (with Stokes, Fischex, R, Po,

Butles, A. Pol . ....... OM-1

$\because S \infty$

Sakakwra, A. Y $_{0} \ldots \ldots \ldots \ldots \ldots \ldots$. . . . . . . TEI-329

. . . . . . . . . . TEM-306

(with Faul) ......... TEM-135

(with Faul, Gott, Manger, Mytton). . TFM-533

(with Faul, Manger). . . . . . TEM-239

Sample, R. Do (and Albee) . . . . . . . TEM-206, 207, 208, $-266,267,268$, $-345,346,347$, $-348,349,456$, $-457,462$

(and Albee, Stephens) . . . . . THM-268A, 350, 351,

(with Bachman, Read). ...... TEMa 510 $-458,463$

(with Sears, J. D.) ........ TEM-671

(with Strobell, Stepheas, H, Go,

Gilbert) ........... TEM-632 


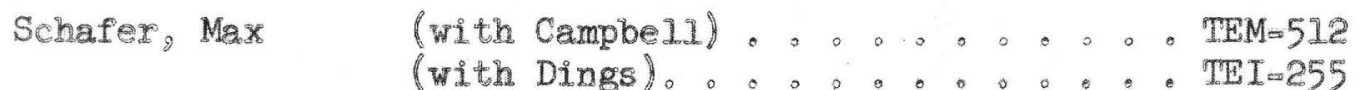

Schallex, W. T. . . . . . . . . . . . . . . . TEM 72

Schesslex, T. E。 (with Jobin). . . . . . . TEM-481

Schlecht, $W_{0} G_{0} \ldots \ldots$. . . . . . . . . TEI $28,31 \mathrm{G}$ (with Foster, Stevens, R. E。

Grimeldi, Fleischer) $00 \circ, 0$. TEI $32 \mathrm{~A}$

Schmidt, $D_{0}$ L。 (wIth Mackin) . . . . . . . TTEM=602

Schnabe1, R. W. (and Vickers) . . . . . . . . TEM-434

Schumacher, I. I. (with Fischer, R。 $P_{0}$, Hilpert, Cater,

Strobe11, Craig, Phoenix, Trace). TEM-276

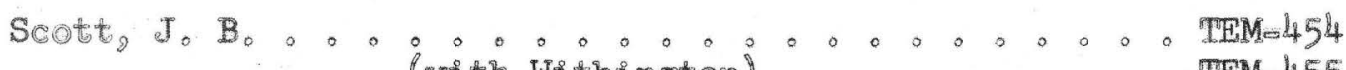

(with Withington):

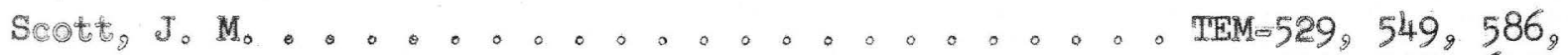
$-595,597,615$, $-619,620,633$, $-634,635,661$. $-662,663,667$, $=669$

Sears, J. Do (and Sample). . . . . . . . TEM-671 
Sears, R。 S,

(with McKelvey, Smith, L。 E。, Kinney, Huddle, Hosford, Sprouse,

Stewraxt, $\left.M_{0} D_{0}\right)_{0} \ldots \ldots$. . . . TEI-185

(with Sheridan, Collier). ..... TEM-288

Senftle, F。 E。 ............... J J 83

(and Champion)..........TEI0401

(and Farley, Stieff).......TEI-374

(with Bracken) ......... TEI-402

(with Flanagan)......... TEI-333

Sharp, W. N, . . . . . . . . . . . TEM- 35

(and Cavender). . . . . . . TEI-351, J-84

(and Cavender). . . . . . . TEM-286, 560

(and 01son)............ OF $=k$

(and Pray)........... O OM-h

(with Nelson, Stead). ...... TEM-147

(with OIson). ........ J-76

(with Wyant, Rodríguez) ...... TEI-222

(with Wyant, Sheridan). ...... TTI-122

Showe, $D_{0} R_{0} \ldots \ldots \ldots \ldots \ldots \ldots \ldots$. . . . . . . .

Sheldon, R. P. (and Cressman, Carswell, Smart) . 。TEI-378 (and Cressman, Smart, Waring, $R_{0} G_{\circ}$,

Thompson, M。E., Weiser, Jones,

R. Jo, Pelrce) ........ OF $-m$

(and Waring, $R$, G., Warner, $M_{*} A_{0}$,

Smart) ................ TEI-363

(and Warner, M. A., Thompson, Mo E。 ,

Peirce)........... TEI 364

(with Cheney, Cressman, Smart,

Carswe11). .......... OF $-\mathrm{b}$

(with Cheney, Peterson, Smart,

Waring, $R$. $G_{0}$, Warner, $M_{0} A_{0}$ ). . . O OF $\times$ a

(with Cheney, Waring, R, G.,

Warner, $\left.M_{0} A_{0}\right)$........ TEI-377

(with McKelvey, Davidson, O'Malley,

Smith, I. E, Armstrong) ......TEI-183

(with McKelvey, Swanson, $R_{0} W_{0}$ ) : : TEI-263

(with O'Malley, Davidson, Hoppin) . TEI-188

(with Smart, Waring, R。 Go, Cheney). TEI-376

(with Swanson, $R_{0}$. Wo, McKelvey) .. TEI-246 


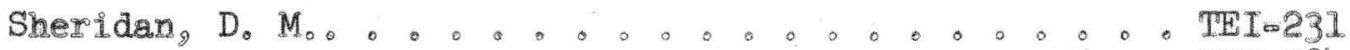

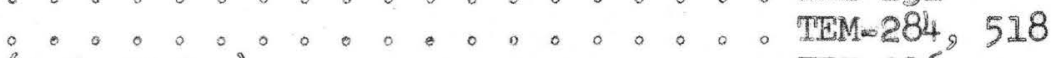

(and others). . . . . . . . TEI-226

(and Collier, Maxwe11). - . . TEI-302

(and Collier, Sears).。.。. . TEM-288

(with Wyant). o. 0.00 .0 .0 TEM-244

(with Wyant, Sharp) o. o. o. . TEI=122

Sherwood, A. M. (with Aberdeen, White, Bruce,

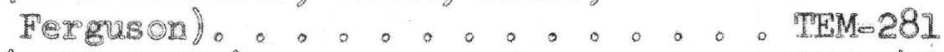

(wIth Jaffe), 0.0000000 .0 TEM-149

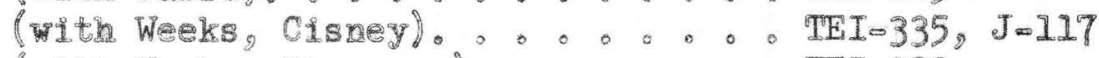

(witk Weeks, Thompson).。.。. TEI-393

Shimamotog Ko O (See also Onoda, Kiyokg)。 。. 。 J-80

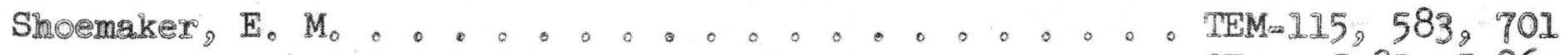

$\mathrm{OF}=\mathrm{n}, J=85, J=86$

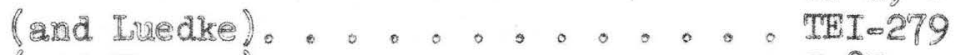

(and Newnar): 0.0 .0 .0 .0 .407

(with Iwedke). . . . . . ०. TEM-301

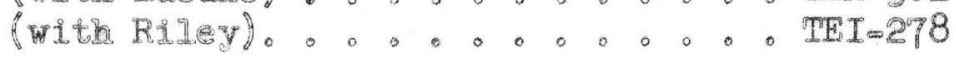

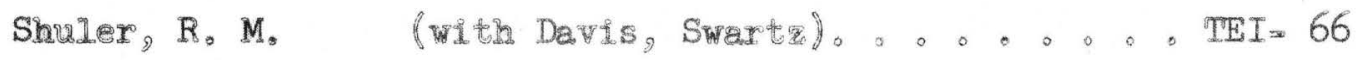

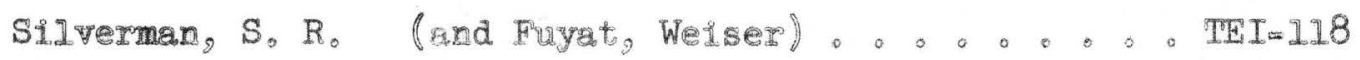

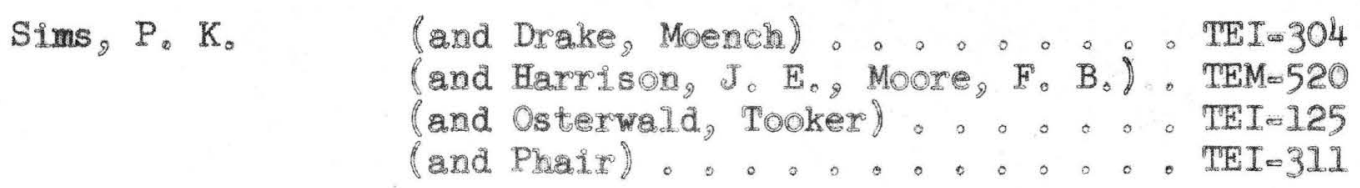

Singewald $Q_{0} D_{0} \cdot 0 \cdot 0 \cdot 0 \cdot 0 \cdot 0 \cdot 0 \cdot 0.0 .0$ TEI-392

(and Christman, Brock)。: 0.0 . TEM-218

(and Wilmarth, Plerson, Vickers).。TEMe224

(with Plerson).。.

(with Pierson, Burbank)。。.。. J J-81 


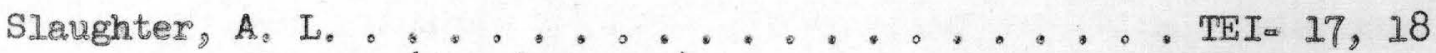
(and Clabaugh). ........ TEI- 1, 3, 9 (and Nelson, J. Mo ) ....... TEI 20

Slavin, Morris (with Fletcher, May)....... TEI-104

Smart, R。A.

(and Waring, R。G, Cheney, Sheldon), TEI-376 (with Cheney, Peterson, Sheldon,

Waring, R。 G., Warner, M. A.). 。. OF -a

(with Cheney, Sheldon, Cressman,

Carswe11). ......... $\mathrm{OF}=\mathrm{b}$

(with Cheney, Waring, R. G., Warner,

$\left.M_{0} A_{0}\right) \ldots \ldots$. . . . . .

(with Davidson, Peirce, Weiser) 。. TEI-365

(with Sheldon, Cressman, Carswell). T TEI $=378$

(with Sheldon, Cressman, Waring,

$R_{0}$ G. , Thompson, M。 E。, Weiser,

Jones, R. J., Peirce)。...... $\mathrm{OF}=\mathrm{m}$

(with Sheldon, Waring, $R_{0} G_{0}$,

Warner, M. A.) ........ TEI-363

(with Swanson, R, W. , Waring, R。 G.,

Peirce, Warner, $M_{0} A_{0}$ ) ...... OF $\approx p$

Smith, H. B... (with Wallace, Blatcher)...... TEI 400

Smith, J, F, Jr.............. TEM-247

(and Hinrichs, Huff, Luedke). . . TEM-538

(and Hinriehs, Luedke)....... TFI-203

(and others)......... TEI-319

(with Gott, McKelvey).......TEM-249

Smith, L. E. (with Fischer, R, Po, Stokes).... OM-a

(with McKelvey, Davidson, O'Malley,

Armstrong, Sheldon)....... TEI-183

(with McKelvey, Hoppin, Armstrong). . TEI-184

(with McKelvey, Kinney, Huddle,

Hosford, Sears, Sprouse,

Stewart, M. D. J. ....... TEI-185

(with WiImarth) ........ TEI-277 


\section{4}

Soister, P.E. (with Troyer, McKayl) .....。TEM 572 (with Troyer, McKay, Wallace, S。R。). TEI- 345

Sokolova, E。 I. (with Kazakov). ... . . 。 TEIo386

Sprouse, D. P. (with McKelvey, Smith, L。E, Kinney, Huddle, Hosford, Sears, Stewart, $M_{0} D_{0}$ ). . . . . . . TEI-185

Staatz, M。 H。 。 . . . . 。 。 . 。 TEM-162, 223

(and Bauer) . . . . TEM=165, 167, 226,

(and Norton, Page, Io Ro, Stephens, $-227,228, J=90$

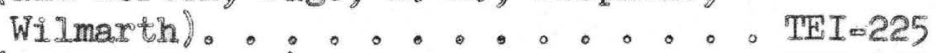

(and Osterwald) . . . . . . TEI-252

(and Trites).......... T TEI-138, Jo9I

(and WiImaxth, Bauer) . . . . . TEI-136

(with Bauer). ........ TEM-220

Staff。................. TEI 78, 97, 270, $-280,310,330$, $-331,390,391$ TEM $37,53 A, 56$,

$-59,64,65$,

- 69, 70, 73,

$-75,78,79$.

$-83,87,88$,

$-91,92,93$,

$-96,97$

Stager, $H_{0} K_{0} \ldots \ldots \ldots \ldots \ldots$. . . . . . . . . . . 10117,146 ........... TEM-103, 332, 491 (with Bush)

(with Cater). . ....... TTM-693

Starrett, W. Ho (and Cannon, H, L。) 。. .... TEM-71I (with Narten) ....... TEM-580 
Stead, F. W.

(and Balsley, Moxham, Reinhardt). . TEM-508

$T E I=13,83,211$, $J=92, J-93, J=94$ TTEM $49,52,84$, $-161,314$

(and Davis, F, J.)......... Ja95

(and Moxham, Davis, F. J.). .... J J 96

(with Butler, A. P.). . ..... TEI= 36

(with Harder) .......... TEI- 21

(with Nelson, R, A, Sharp) .... TEM-147

Stejer, F。A. (with Wedow, Bates, Grantz,

Houston, Killeen, Matzko, Nelson,

Velikanje, West) ........ TEM-552

Stephens, H. G。

(and Cramers).

(and Ekren). . . 。 . . . . TEM-297

(and Newman).......... TEM-201

(with Semple, Albee). . . ... TEM-268A, 350, 351,

(with Staatz, Norton, Page, Wilmarth). TEI-225

458,463

(with Strobe11, Sample, Gilbert). . TEM-632

Stephens, Jo Go (with Moore, G. W.) ....... TEI-337

Sters, T。W. .............. . TEI-129

(and Stieff). . . . . . . TEM-647

(and Weeks) .......... TEI-243

(with Stieff) .......... TEI 127 , 322, J-99

(with Stieff) ......... TEM-317

(with Stieff, Gixhard). . . . . TEI-106, 108

(with Stieff, Milkey) ...... TEI=268, J-102

Stevens, Jo M. (with Wedow, Tolbert) .......TEI=197

(with White, M. G.) . . . . . . TEI- 75, 192, 193 


\section{6}

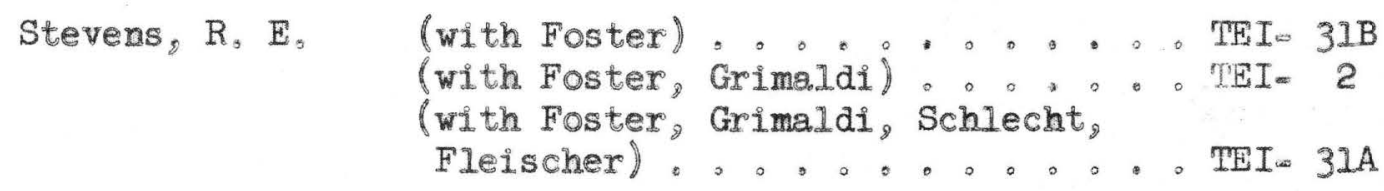

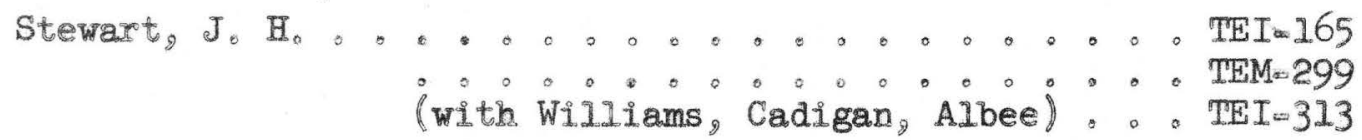

Stewart, Mo D. (with McKelvey, Smith, I. E, Kinney, Huddle, Hosford, Sears, Sprouse) 。. TEI $=185$

Stewart, $R_{0}$ H. . . . . . . . . . . . . . . TEI 100

*.。. . . . . . . . . TEM=255

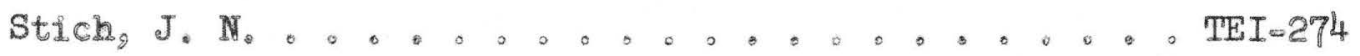

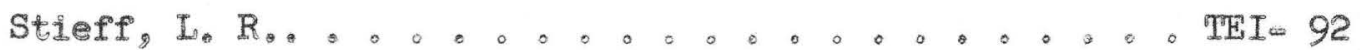

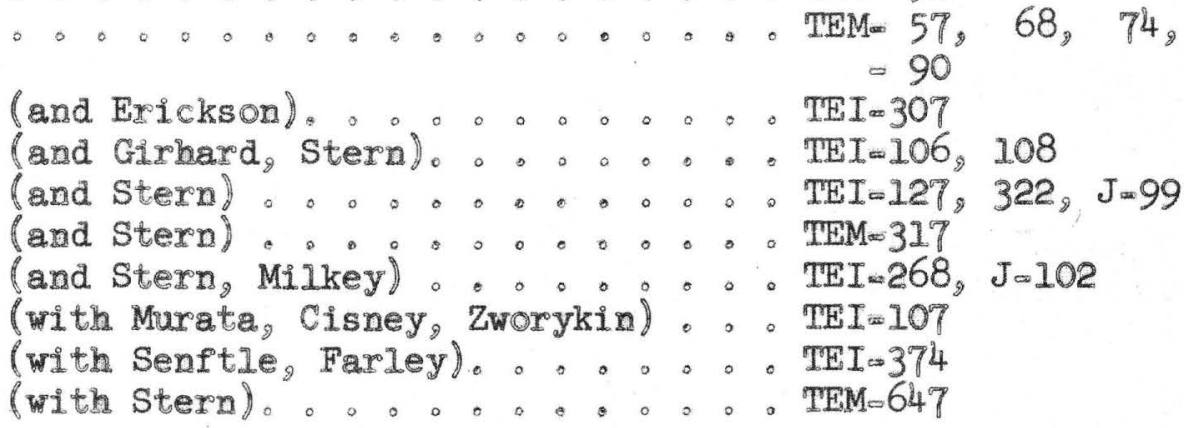

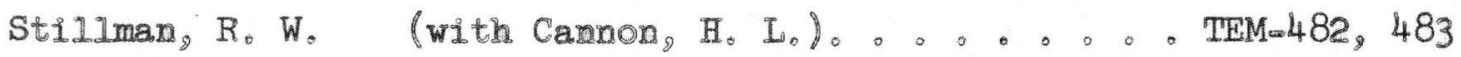

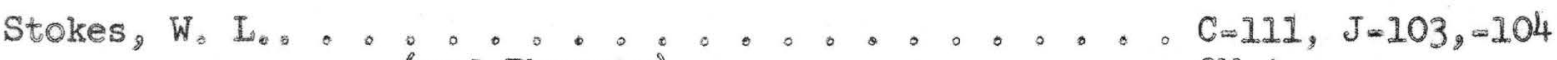

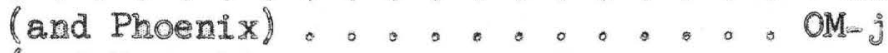

(and Russell, Fischer, $R_{0} \mathrm{P}_{0}$, Butler, A. P.) O. O. O. O OM(with Fischer, $R_{0} P_{0}$, Smith, L, E。) OM- 
Stratton, E. V. (with Nelson, J. M. )....... TEI 34

Strobe11, J. D., Jr................ TEM=300, 415, 416, $417,418,419$, $-420,421,422$, $-423,424,425$, $-426,427,428$,

(and Sample, Stephens, $H_{0} G_{*}$, $-429,430$

Gilbert) ........... TEM=632

(with Fischer, R。 Po, Hilpert,

Schumacher, Cater, Craig,

Phoenix, Trace). ....... TEM-276

Stugard, Frederick,

Jr. ..................... TEI-233, 254, J-105

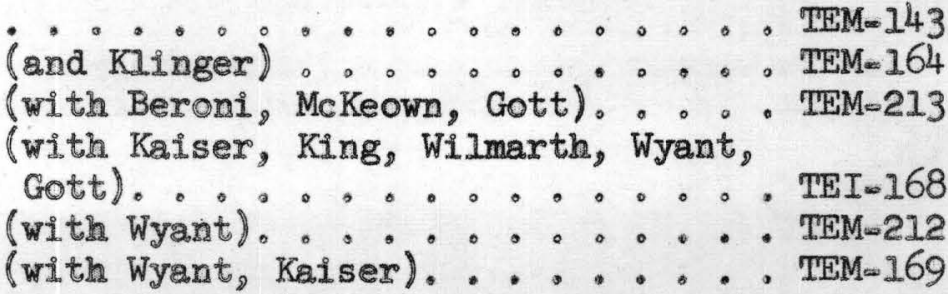

Suess, $H_{2} E_{0} \ldots \ldots \ldots \ldots$. . . . . . . . . . . .

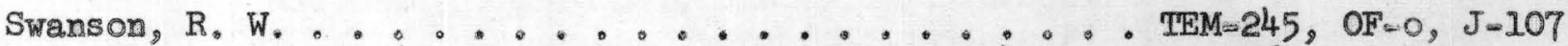

(and Cressman, Jones, Replogle)...TEI-362

(and Klepper, Lowell, Honkala,

Cressman, Bostwick, Payne, Ruppel) 。TEIm-186

(and McKelvey, Sheldon)..... TEI-246

(and Waring, R. G., Peirce, Warner,

M. Ao, Smart). . . . . . . OF $=\mathrm{p}$

(with McKelvey)........ TEImIII

(with McKelvey, Cathcart,

Altschuler, Lutz). ....... TEI-27I

(with McKelvey, Sheldon). . ....TEI-263

(with Peterson, Gosman) ...... TEI-375 


\section{8}

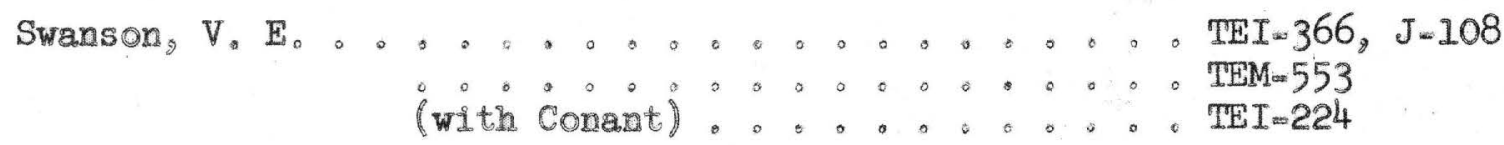

Swartz, J. H. (with Davis, Shuler) 。 。 , . 。 TEI 66

Tandy, C.W. (with Cressman, Wilson, Garmoe). . TEI-361

Thaden, $R$, E. (with Witkind, Johnson, D. E.,

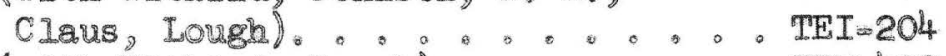

(with Witkind, Lough) 。. . . . TEM 492, 536, 577

Theobald, $P, K_{*}$, Jr。

(with Overstreet) ........ TEM 283 (with overstreet, White, A. M. Cuppels, Caldwe11, Whit 10w). ... TEI-349

Thompson, M. E..., ......., ....... TEI-142, 275

(with Sheldon, Cressman, Smart,

Waring, $R$, G. Weiser, Jones, $R$, Jo,

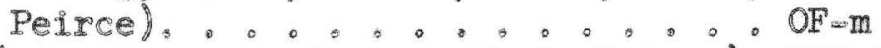

(with Sheldon, Warner, M,A. Peirce) , TEI-364

(with Weeks). .......... TEI-334

(with Weeks, Sherwood).。.... TEI-393

(with Weeks, Thompson, R。 B, Jro). J J119

Thompon,

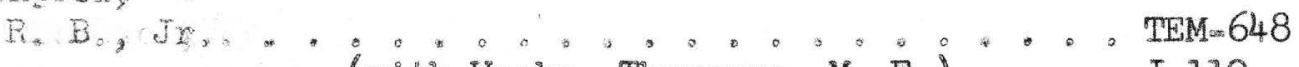

(with Weeks, Thompson, $\mathrm{M}_{0} \mathrm{E}$ ) $: \circ \cdot \mathrm{J}-119$ 
Thurston, $\mathrm{R}, \mathrm{H}, \quad$ (and Chace) ......... TEI- 8IA

(and Trites)......... TEI-171, J-109

Thurston, W. R. ................. TEI 139

TEM-104, 105, 106

Tillman, C. G. (with Cathcart, Davidson, Dutro, Ketner, Petersen, Pratt)..... TEM=138

(with Cathcart, Dutro). . . .... TEI-14I

Tittle, C.W. (and Frus). ......... J-110

(with Faul) ......... J-30

Tolbert, G. E. ............. TEM $-372,373,374$, $-375,378,379$, $-380,381,382$, $-398$

(and Hackman) ........ TTEM-379A

(and Nelson, A, E.) ...... TEM-319

(with Hackman). . ....... TEM-380A, 640

(with Nelson, A. E。). . .... TEM-320

(with Wedow). . . . . TEI-195, 196

(with Wedow, Stevens, J.M.).... TEI=197

(with White, M。 G.) ....... TEI-194

Tooker, E.W. (with Sims, Osterwald)....... TEI-125

(with Trites) ......... TEI-140

Tourtelot, H. A, ............ TEM $=445$

Trace, R, D. ................ TEI-113, 162

$T E M=80,176,177$,

$-178,179,181$,

$-182,184,185$

(with Bush, Hilpert)...... TEI-116

(with Fischer, R。 $\mathrm{P}$, Hilpert,

Schumacher, Cater, Strobell,

Craig, Phoenix)......... TEM $=276$ 


\section{OFFICIAL USE ONLY}

260

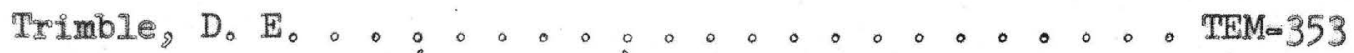

(and Lewis) 0.00 .0 TEI-321

(and Lewis) 0.0 .0 .0 .00 TEM-535

Trites, A. Fo, Jro (and Beroni, Benson, W。 E。) . . . TEIo240 (and Chew) 0.0 .0 TEM 645 (and Finne11) 。. . . . . . T TEI 320 (and Finneli) 0.0 .0 .0 .0 TEM-540 (and Tooker). 0.000 .0 .0 TEI-140 (with Benson, W。E。 Beroni, Feeger)。 TEM- 325 (with Finnell, Rencetti)。。.。.TEM-479

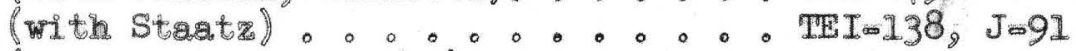

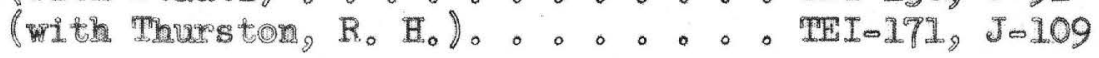

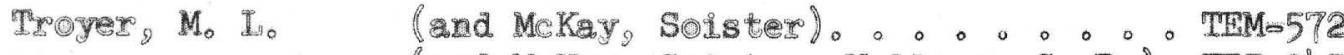
(and MeKay, Solster, Wallace, S。R.)。TEI-345

Tucker, Wo P. (and Waring)。 . . . . . . TEI-267

$$
-V_{0}
$$

Vaughn, $W_{0} W_{0}$ (with Wilson, Rhoden, Faul) 。.。.TEI-403

Velikanje, R。 S. (with Houston, Bates, Wedow).。.。TEI-293 (with Wedow, Bates, Grantz, Houston, Killeen, Matzko, Nelson, Ste Jer, West). . . . . . . TEM-552

Vhay, Jo S. . . . . . . . . . . . . . . . TEM= 30,197 
Vickers, R. C................ TEI-200, 201, 202, $-303,384$

(with Schnabel)........ TEM-434 TTM- 519, 558, 559, $-740,741,742$

(with Singewald, Wilmarth, Pierson). TEM-224

(with Wilmarth) ........ TEI-176

(with Wilmarth, McKeown, Beroni). . TEI-124

Vine, J. D........................ TEM55

(and Bachman, Read, Moore, G. Wo) . T TEI-24I

(and Flege) ............... TEI-336

(and Moore, G. W.)......... TEI-28I

(and Moore, G. W.)........ TEM-340

Vogel, J. D. ...................... TEM-302, 494

(and Elston)。........ TEM-725

(with Cater).......... TEM-702

$\infty W=$

Walker, G. W. . ............... TEM-514, 554, 674 (and Lovering, T。 Go) ....... TEI-229 (with Moxham, Baumgardner). .... TEI-380

Wallace, J。 $\mathrm{H}_{0}$ (and Blatcher). ........ TEI-300

(and Blatcher, Smith, H, B.). . . TEI 400

(with Blatcher) ......... TEI - . 325

Wallace, S. R. (with Olson).......... TTI-353

(with Troyer, McKay, Soister) . . . TEI-345

Ward, E. L. M, (with Cathcart)........ TEMM-672 
Waring, C。L。

(and Anne 11)。 . 。 . . 。 TEI-143, 215

(and Mela). o. 0.0 .0 .0 TEI-239

(and Worthing). 0.00 .0 .0 TEI-216

(with Lassen, Berman, J.) 。. . . J J 61

(with Tucker) 。.......... TEI-267

Waring, $R$ 。 $G$ 。

(with Cheney, Peterson, Sheldon,

Smart, Warner, Mo Aol. O O O. O OF-a

(with Cheney, Sheldon, Warner, Mo $A_{0}$ )。 TEI-377

(with Cheney, Smart, Warner, M. A.) , TEI 360

(with Sheldon, Cressman, Smart,

Thompsor, $M_{0} E_{0}$. Weiser, Jones,

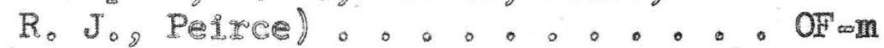

(with Sheldor, Warner, Mo Ao, Smart)。 TEEI-363

(with Smart, Cheney, Sheldon) 。. . TEI-376

(with Swansor, R。 Wo, Peirce,

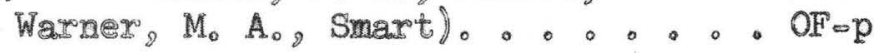

Warner, E。 R.

(with Fleteher) . . . ..... TEM-252

Warner, Io A。

(and Holser, Wilmaxth, Cameror) o. TEI-137, J-50

Warner, $M_{0} . A$.

(with Cheney, Peterson, Sheidon,

Smart, Waring, $R_{0} G_{0}$ ). . . . . OF $\times a$

(with Cheney, Sheldon, Waring, R.G.)。TEI-377

(with Cheney, Smart, Waring, R. G.). TEI-360

(with Sheldon, Thompson, Mo E。

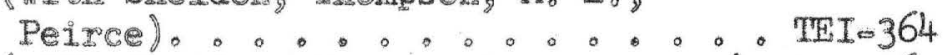

(with Sheldon, Waring, $R$ 。 $G_{0}$, Smaxt)。 IEI-363

(with Swanson, $R$ 。 Wo, Waring, $R$, G。,

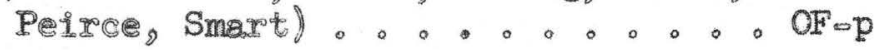

Wars, J.J., Jr. (with Breger, Meyrowitz).。ㅇ。. TEI-372

(with Flanagan, NeIson, J.M.).。.IEM=142 
Waters, A. C. (and Granger) ......... TEI-170

Waulters, E. E, (with Fetzer, Fischer, R, P.) . . . TEI- 89

Wayland, T, E. .. . . . . . TEM-230, J-115

(with Davidson)........ TEM-123

Wedow, Helmuth, Jr.................. TEI 56

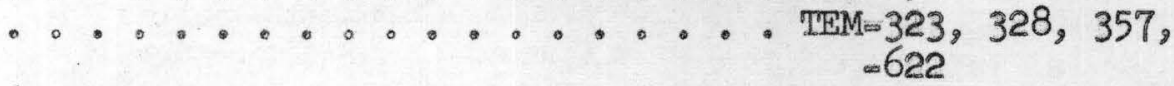

(and Bates, Graatr, Houston,

Killeen, Matzko, Nelson,

Velikanje, West, Stejer) ..... TEM-552

(and Matzko). .......... TIEI 38

(and Stevens, J. M., Tolbert) . . . TTI-197

(and Tolbert) .......... TEI-195, 196

(and White, M. G, Moxham)。.... TEM-235

(with Bates, R。 Go) ....... TEM-339

(with Houston, Velikanje, Bates). . TEI-293

(with Robinson, Lyons)........ TEIm 26

Weeks, A. D. .................. TEI-285, J-116

$\ldots \ldots \ldots$ TEM-251, 431,437

(and Cisney, Sherwood).......TEI-335, J-117

(and Thompson, M, E.) ....... TEI- 334

(and Thompson, Sherwood).......TEI-393

(and Thompson, M, E., Thompson,

$\left.R_{0}, B_{0}, J x_{0}\right) \ldots \ldots . . . . . . . . .119$

(with Stern).......... TEI-243

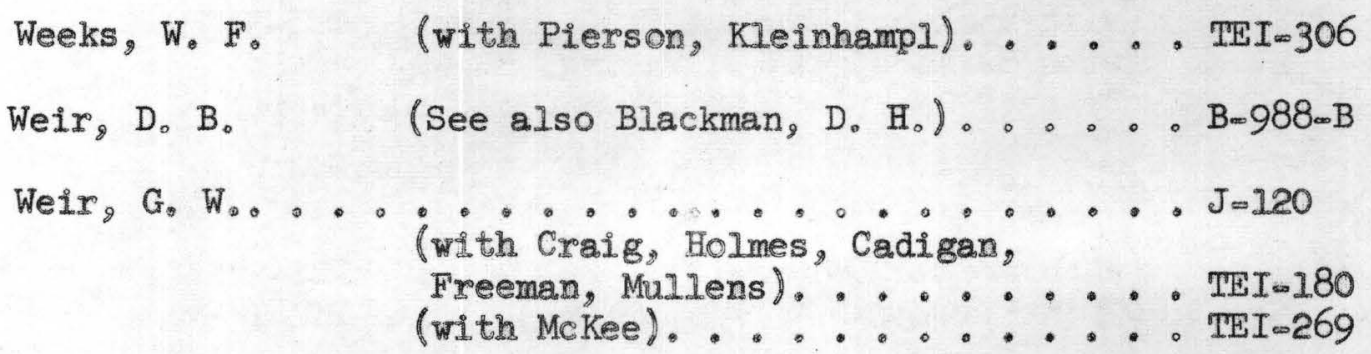


Weiser, J. D.

(with Davidson, Smart, Peirce). 。 TEI 365

(with Sheldon, Cressman, Smart,

Waring, $R$, $G$, Thompson, $M, E$,

Jones, R. J., Peircel). .,..., OFsm

(with Silverman, Fuyat)...... TrEI 118

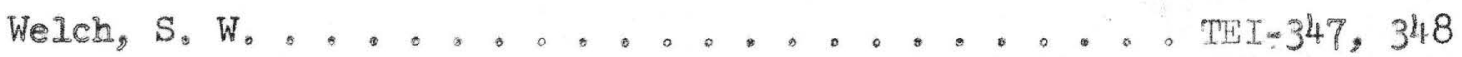

We11s, $J, D$.

(and Harrison), a..., . . TEI-305

(with Harrison).......... TEI-295

West, W. S..., ..................., TEI- 53,291

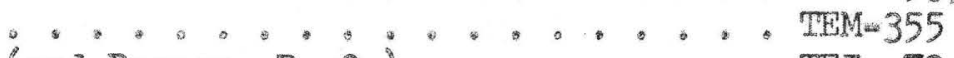

(and Benson, P, O.)........ TEI 73,189

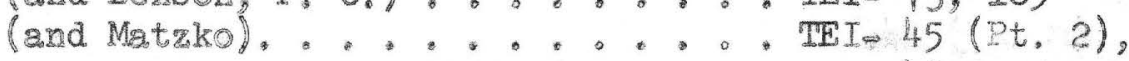

$-49$

(With Moxham)......... TEI 39

(with Moxham). . ..... TEM- 330

(with Ne1son, Matrko) ....... TEI- 292

(with Wedow, Bates, Grantz, Houston,

Killeen, Matrko, Nelson, Stejer,

Velikane) . . ........ TEM-552

(with White, M. G.) *, ..... IEI-220, 221

(with White, M, G.) ........ TEM-s22

White, A. M. (with Overstreet, Theobald, Cuppels,

Caldwe11, Whit Iow) :.............

White, $M_{*} G_{*} \ldots \ldots \ldots$ TEI $40,55,57 \mathrm{~A}$, $-57 \mathrm{~B}, 57 \mathrm{C}, 76 \mathrm{~A}$

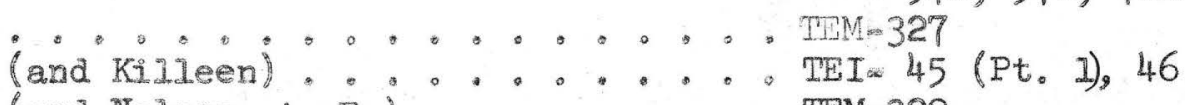

(and Nelson, A. F.)........ TEM- 329

(and Stevens, J. M.). ....... TEI $75,192,193$

(and Tolbert) , ......... TEI 194

(and West).

(and West)............ TEM-322

(with Kilieen)。........, TEI- 42

(with Wedow, Moxham). ......TEM-235 
White, W. F. (with Aberdeen, Sherwood, Bruce, Ferguson).......... TEN-281

White, W. S... jand Wright $). \ldots \ldots$ TEM- 34

Whitebread, D。W. (with Beroni) .......... TEM-293 (with Gillerman)........ TEI-261

Whitlow, J. W. (with Overstreet, Theobald, White,

A. Mo, Cuppels, Caldwell)..... TEI $=349$

Williams, G. A. (and Cadigan, Albee, Stewart) ... TFI-313

Wi $\operatorname{marth}, \mathrm{V}, \mathrm{R} . \ldots \ldots \ldots . . \ldots \mathrm{TEI}=253,299, \mathrm{~J}-121$

....................... 36, 307, 313

(and Johnson, D. H.)....... TEI-158, 172

(and Smith, I. E.). . . . . . TEI-277

(and Vickers) ....... TEI=176

(and Vickers, McKeown, Beroni). . . TEI-124

(with Bales, Bell)........ J $=5$

(with Kaiser, King, Stugard, Wyant,

Gott). ............ TEIw168

(with Singewald, Pierson, Vickers)。. TEM-224

(with Staatz, Bauer). . . . . . TEI-136

(with Staatz, Norton, Page, L. R。,

Stephens). . . . . . . TEI-225

(with Warner, I. A., Holser, Cameron) TEI $=137, J=50$

Wilson, E. E. (and Rhoden, Vaughn, FauI)..... TEI-403

Wilson, W. H. (with Cressman, Tandy, Garmoe). ... TEI-36I 


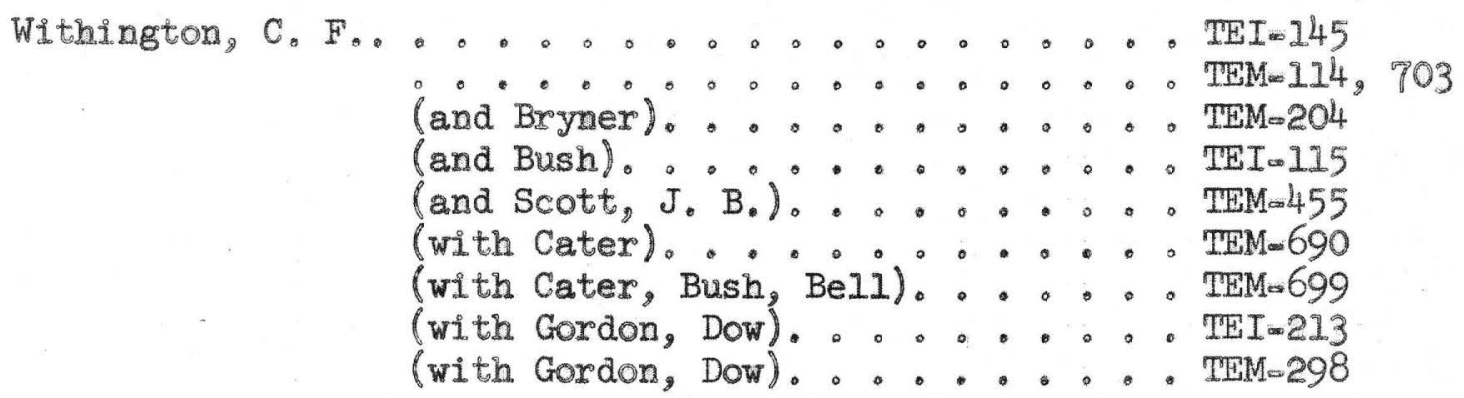

Witkind, I. Jo (and Thaden, Johnson, D. H., Claus,

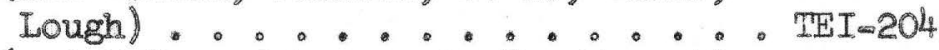
(and McKay, Johnson, $D_{0}$ H., Finneli, Claus, Johnson, D. L。) ..... TEM=318 (and Thaden, Lough) . ...... TEM-492, 536, 577

Wolfe, J.R. (with Bri11)............TEI- 19

Worthing, Helen (with McKelvey, Cathcart)..... THM-236 (with Waring).......... TEI-216

Wright, J. C. (with White, W. S.) ........ TEM-158

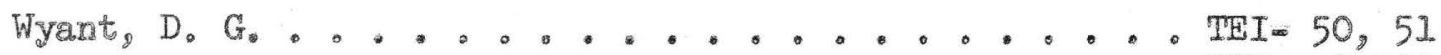

...................... 2EM 2, 2A, $-8,9,9 A$, $-10,10 \mathrm{~A}, 14$, $=15,16,17$, $=54,211,221$, $=331$

(and Beroni)........... IEI 61

(and Beroni)...................... 126

(and Sharp, Rodríguez). ...... IEEI-222

(and Sharp, Sheridan)....... TEI-122

(and Sheridan). ......... TEM-244

(and Stugard)........... TEM=212

(and Stugard, Kaiser) ...... TEM-169

(with Harder).......... TEI 4

(with Kaiser, King, Wilmarth,

Stugard, Gott) .......... TEI-168 


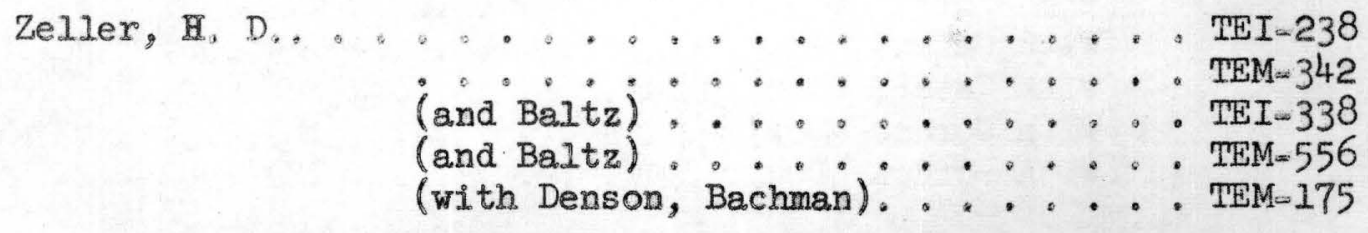

Zworykin, E, V. (with Murata, Cisney, Stieff) . . . TEI-107 